\title{
EL DELITO DE OMISIÓN EN LAS FUERZAS MILITARES
}

\author{
JOSÉ Álvaro VARGAS LANCHEROS
}

UNIVERSIDAD SANTO TOMAS CONVENIO UNIVERSIDAD DE SALAMANCA

FACULTAD DE DERECHO MAESTRIA EN DERECHO PENAL 


\section{CONTENIDO}

Introducción

1. El poder político y las Fuerzas Militares 9

2. El Delito de omisión 27

2.1. La Omisión propia 35

2.1.1. Omisión Propia en el Código Penal Militar 36

2.1.2. Omisión propia en el Código Penal Común 38

2.2. La Omisión impropia 49

2.2.1. La posición de garante $\quad 60$

2.2.1.1. De la competencia funcional 68

2.2.1.1.1. Condiciones estructurales de la misión de las Fuerzas Militares $\quad 78$

2.2.1.2. La obediencia debida $\quad 85$

2.2.2. De la competencia territorial 93

2.2.2.1. Los límites de tiempo 96

2.2.2.2. Los límites de espacio 98

2.2.3. De la competencia material 100

3. La imputación objetiva y el delito de omisión impropia 113

3.1 Riesgo permitido 117

3.2 Principio de confianza 124

3.3 Prohibición de regreso 131

3.4 Competencia de la víctima 132

4. El fuero militar $\quad 137$

$\begin{array}{ll}\text { Conclusiones } & 151\end{array}$

Bibliografía 


\section{INTRODUCCIÓN}

La sumatoria de la naturaleza que entraña la amplia y compleja misión de las Fuerzas Militares, el protagonismo e importancia de los conceptos de Dignidad Humana, Derechos Humanos y Derecho Internacional Humanitario, y el impacto que se produce en la sociedad cuando emergen la violación de tales derechos, hace necesario que se indague minuciosamente por la estructura general del delito de omisión que rige el sistema penal colombiano, particularmente por la Omisión Impropia, en aras de conocer y fortalecer su significado e implicaciones dentro de las Fuerzas Militares, buscando generar a su vez herramientas preventivas y probatorias que aminoren las consecuencias jurídicas que se crean, de una parte, por la dinámica veloz y agresiva de las operaciones militares, y de otra, por las distintas interpretaciones y derivaciones en los fallos de las Altas Cortes, que se dirigen a aristas trascendentales como la aplicación de los Derechos Humanos y el Derecho Internacional Humanitario, la colisión de competencias de la jurisdicción militar con la justicia ordinaria (fuero militar), y el mismo reproche, a veces ruidoso, a veces silencioso, que le hace la sociedad a la Institución Militar.

El tema de la Seguridad y Defensa Nacional es motivo de debates políticos, como otros tantos aspectos de la dinámica política del Estado, se exaltan aquellos que tocan los Derechos Humanos y el Derecho Internacional Humanitario, en ellos se busca establecer leyes y/o estrategias que direccionen con firmeza la misión de las Fuerzas Militares, la normatividad que resulte pueda influir positiva o negativamente en el rol institucional, hecho que trasciende directamente sobre los integrantes de cada una de las Fuerzas y en los distintos escalones de mando y de ejecución. A la expectativa de la normatividad se le suma la velocidad y violencia del conflicto, lo que multiplica la creación de riesgos por acción y por omisión para los derechos fundamentales, especialmente para los bienes jurídicos de la vida y la libertad individual, lo que hace que permanentemente el estamento castrense sea un sujeto institucional de derecho en la mira del sistema jurisdiccional civil nacional e internacional. En este contexto, la misma estructura penal militar logra ser puesta en entredicho, el fuero militar es minimizado y algunas investigaciones ya han sido alcanzadas 
por instancias internacionales del derecho ${ }^{1}$, es lo que hace imperioso, el análisis, la actualización, y aplicación de la normatividad institucional en su conjunto.

El debate que ofrecen distintos fallos de la Justicia, como los casos del Palacio de Justicia ${ }^{2}$ y Mapiripan ${ }^{3}$, y aún uno de los últimos pronunciamientos del Consejo de Estado ${ }^{4}$ que tienen relación con la acción y la omisión, entre otros, hacen que hoy más que nunca sea oportuno examinar, indagar y reflexionar precisamente sobre el condicionamiento de la norma, particularmente de la omisión impropia con la situación del conflicto colombiano y el accionar que demanda éste a los integrantes de las Fuerzas Militares, ajustado a la aplicación de los Derechos Humanos y del Derecho Internacional Humanitario.

De otra parte, debe destacarse que la conducta omisiva como tal, es protagonista de intensos debates académicos, ya que el laberinto para su estructuración punitiva requiere de una precisión quizá más exigente que para las mismas conductas de acción. En efecto, grandes maestros del derecho le han hecho evolucionar tanto en su definición como en su estructura, justamente por la complejidad de las dificultades que entraña el estudio de la Omisión Impropia, y de modo particular su aplicación. En consecuencia esto hace que los mismos Estados, en la reestructuración de los códigos, sientan la necesidad de revisar la

${ }^{1}$ Cfr. casos La Rochela, Mapiripan, Pueblo Bello, Ituango. En: www.corteidh.or.cr/pais.cmf?rd_pais=9

${ }^{2}$ Caso toma del Palacio de Justicia de Colombia: Los hechos ocurrieron los días 6 y 7 de noviembre de 1985, cuando el autodenominado grupo guerrillero M-19 (Movimiento 19 de abril) se toma a sangre y fuego las instalaciones del Palacio de Justicia en la ciudad de Bogotá. Como consecuencia de la retoma hecha por las autoridades se investiga la desaparición de algunas personas, por lo que se han proferido sentencias condenatorias, entre las cuales se puede consultar la emitida por el Tribunal Superior de Distrito Judicial de Bogotá, Sala Penal, Rad. 110010704003200800025 09, de enero 30 de 2012 (decide apelación sentencia del Juzgado $3^{\circ}$ Penal del Circuito Especializado).

${ }^{3}$ Caso Mapiripan: (Los hechos ocurrieron entre el 15 y el 20 de julio de 1997). Un grupo de sujetos de las autodenominadas Autodefensas Unidas de Colombia, vestidos con prendas de uso privativo de las Fuerzas Militares, penetró al municipio de Mapiripan (Meta), donde agredieron a la población y asesinaron un número aproximado de 49 personas [cfr. Sentencia SU-1184 de 2001 (Conflicto de competencias) y Proceso 25889 de 2007 (Caso Mapiripan, Casación)].

${ }^{4}$ Caso toma Base Militar Las Delicias: La Base Militar ubicada en el Municipio de La Tagua (Putumayo), estaba ocupada por más o menos cien uniformados, quienes el 30 de agosto de 1996 fueron atacados por el grupo guerrillero de las FARC (Fuerzas Armadas Revolucionarias de Colombia). A pesar de la resistencia de los militares, la distante ubicación de la base y las dificultades de apoyo, entre otras circunstancias, arrojó lamentables resultados, tales como la muerte de más o menos treinta soldados y el secuestro de otros sesenta uniformados [cfr. Sentencia de 25 de mayo de 2011, Rad. 52001233100019970878901 (15838, 18075, 25212 acumulados), Consejero Ponente: Jaime Orlando Santofimio Gamboa; y sentencia 25 de mayo de 2011, Rad. 52001-23-31-000-1998-00515-01 (18747), Consejero Ponente: Jaime Orlando Santofimio Gamboa. 
identidad de esta norma general con sus orillos, intentando actualizar y ampliar con mayor exactitud su ordenamiento legal para acertar mejor en la ejecución de la norma.

Si bien la discusión sobre la omisión se ha presentado con profundidad y las Altas Cortes han fijado ya importantes rumbos en dirección a la Omisión Impropia hacia los miembros de las Fuerzas Militares, se puede asegurar que los escritos doctrinarios dirigidos hacia la omisión en la Institución son escasos, o por lo menos poco conocidos. No obstante, se advierte que al interior de la Justicia Penal Militar el nuevo Código de 2010 (Ley 1407), incorpora el artículo 27 con referencia a la Acción y a la Omisión, que sin duda abre el debate propio de los profesionales del derecho, y mucho más cuando es de tipo abierto, es decir, con características de una norma general, que implica consultas y conocimientos adicionales de las fuentes del derecho y de la doctrina Militar.

Lo anterior amerita atención, debido a que la problemática puramente castrense se presenta desde el planeamiento hasta la dirección y la ejecución de las operaciones militares, donde se enmarcan múltiples circunstancias de tiempo, modo y lugar, adicionándole la pluralidad y complejidad de las informaciones (alertas) de inteligencia que reciben antes y durante las acciones castrenses, situación generada por la capacidad terrorista y de engaño de los agentes generadores de violencia, lo que deriva en realidades que dan lugar al comportamiento omisivo. Se agregan igualmente factores externos e internos que hacen más fácil involucrar a los miembros de la Institución en verdaderas batallas jurídicas; factores externos como las presiones políticas internacionales por el respeto a los Derechos Humanos y al Derecho Internacional Humanitario, la amenaza de intervención de la Corte Penal Internacional, los pronunciamientos de la Corte Interamericana de Derechos Humanos, la misma dinámica política interna, la que ejercen las Organizaciones No Gubernamentales y la que despliega la misma sociedad, y de otro lado, los factores internos como el posible desconocimiento de la normatividad legal respecto a la Omisión Impropia, la dinámica jurisprudencial y su alcance al interior de las instituciones castrenses, porque seguramente no lo consideran parte esencial de estudio en su rol cotidiano, agregándole, en consecuencia, cierta carencia documental en materia penal y 
posibles fallas, al no involucrar y ofrecer directamente en sus recursos doctrinales militares las herramientas defensivas proporcionales y coherentes con la problemática jurídica que se le plantea a la Institución por los diversos flancos, ya sea por los errores cometidos, por la normal vigilancia de los estamentos de vigilancia estatal ${ }^{5}$ o por los contradictores de la Institución a nivel nacional o internacional.

Con este marco, con la normatividad consultada, el conocimiento directo de la Institución Militar y la práctica en los estrados judiciales, se formuló el siguiente interrogante: ¿Existe un desconocimiento del tipo penal de Omisión Impropia en las Fuerzas Militares, que se haya convertido en un flanco débil Institucional frente al sistema de derecho penal, y de cara a los derechos fundamentales de la vida y la libertad de los cuales son sus máximos defensores?

En consecuencia, se busca describir el tipo penal del delito de omisión impropia de acuerdo con la normatividad legal y la Jurisprudencia reciente de las altas Cortes, de tal manera que contribuya al conocimiento de la norma general y sus laberintos para la tipificación, con análisis y crítica basado en la experiencia de casos reales, se quiere, promover la sana discusión de los operadores de justicia, buscando fortalecer la estructura argumental jurídica necesaria para la defensa de los derechos de integrantes de las Fuerzas Militares, sindicados como resultado de acciones y omisiones que se le imputa a los militares, con motivo de la misión que cumplen y particularmente la relacionada con el conflicto interno.

El trabajo desarrollado se dividió básicamente en tres temas:

En primer lugar, unas generalidades que contienen aspectos del poder político y del estamento militar en una mixtura funcional, ofreciendo amplias alternativas de debate entre la seriedad en la fijación de políticas de seguridad y defensa, y la materialización de la misión de las Fuerzas Militares. Podemos afirmar que en el tema de la seguridad y defensa, que los objetivos buscados, si bien no son opuestos, sí van por carriles distintos de la

\footnotetext{
${ }^{5}$ Fiscalía General de la Nación, Procuraduría General de la Nación, Defensoría del Pueblo.
} 
autopista, por ejemplo: los políticos caminan hacia su electorado y en lo funcional medianamente en la búsqueda de los objetivos constitucionales, y los militares, en el concepto general de subordinación, transitan en dirección de lo que disponen los presidentes de turno y lo que les ordena la Constitución, de este marco brotan temas de sumo interés como la discusión seria y objetiva del fuero militar y sus desviadas interpretaciones y no menos protuberantes son la aplicación de figuras como el de persona protegida, el dolo y la coautoría, el concierto para delinquir y la autoría mediata por dominio de organizaciones de poder.

La segunda parte comprende un breve análisis introductorio de la omisión propia, teniendo en cuenta la jurisdicción militar y la jurisdicción común, para seguidamente incursionar en el tema central de la Omisión Impropia y sus aristas, dirigida hacia la institución castrense, escenario en el cual se examina la posición de garante y sus principales elementos relacionados con las capacidades funcionales, territoriales y materiales, como consecuencia de la asunción voluntaria que les atañe a los militares, se advierten las dos situaciones en que los militares pueden ser garantes, ya sea por la "creación de riesgos para bienes jurídicos o surgimiento de deberes por la vinculación a una institución estatal"; se plasman comentarios relativos a las condiciones estructurales de la misión de las Fuerzas Militares y su desarrollo jurisprudencial, así como lo concerniente a la obediencia debida y a lo que se ha denominado los límites de tiempo y espacio.

De igual manera, este trabajo, en el marco de la teoría del delito ventila las tendencias finalista y especialmente la imputación objetiva, la primera, se justifica entre otros aspectos, de frente a la intención final de la acción, en donde figuras dogmáticas como el dolo, la autoría y la coautoría propia e impropia, son indebidamente interpretadas y aplicadas por algunos operadores de justicia, cuando se trata de ubicar y probar la conciencia y la voluntad y el mismo conocimiento de la antijuricidad, lo uno en el tipo objetivo y lo otro como parte de la culpabilidad; lo anterior es dable confrontarlo con la realidad del soldado, quien sale a ejecutar la acción por voluntad del Estado en virtud de que aquel ha asumido voluntariamente la responsabilidad de actuar en su defensa. 
Seguidamente se busca una aproximación a las implicaciones de la Omisión Impropia, en el marco de la imputación objetiva y sus principales elementos limitantes. Avocar la tendencia del funcionalismo representada en la imputación objetiva no es menos interesante, en el trabajo se describe un poco de cada uno de sus componentes, es decir, el riesgo permitido, el principio de confianza, la prohibición de regreso y el comportamiento de la víctima; se introduce al tema por las connotaciones que tienen las funciones que cumplen las Fuerzas Militares precisamente con los eventos en que los miembros de la Fuerza Pública pueden ser garantes: la creación de riesgos para bienes jurídicos o el surgimiento de deberes por la vinculación a una institución estatal, tal como lo expreso el Tribunal Constitucional en la sentencia SU 1184 de 2001; estos eventos son, si se quiere, la medula de la misión constitucional, por la misma velocidad y agresividad de la dinámica operacional de las Fuerzas Militares, lo que hace que a diario se están creando múltiples riesgos y a diario se reciben gran cantidad de solicitudes de apoyo en defensa y/o protección de bienes jurídicos, es decir, el cumplimiento de deberes de salvamento.

En ese orden, se procura con el presente trabajo fortalecer el conocimiento del tipo penal del delito de Omisión Impropia frente al derecho penal colombiano, razón por la cual se proponen relaciones directas con el respeto de los Derechos Humanos y el Derecho Internacional Humanitario, en coherencia con la misión institucional, induciendo a la Institución castrense a vigorizar la estructura argumental jurídica necesaria para la defensa penal en el ámbito de acciones de orden público y de enfrentamientos dentro del conflicto interno a que se ven avocadas las Fuerzas Militares en Colombia.

Muy brevemente se agrega a este estudio, algunas inquietudes sobre las figuras antes enunciadas de la persona protegida, el dolo y la coautoría, el concierto para delinquir y la autoría mediata por dominio de organizaciones de poder, también se plasma la posición sobre el fuero militar, figura en discusión, que requiere un tratamiento serio y proporcional a las necesidades del Estado. 
Es conveniente aclarar que el trabajo no es un estudio dogmatico, más bien tiene una tendencia mixta por la escases de bibliografía que se relacione directamente con la omisión hacia las Fuerzas Militares como posibles sujetos activos de la conducta omisiva, razón por la que se acude entonces, a localizar documentación que, aunada a la experiencia militar y jurídica del autor, permita hacer análisis que den respuesta a la hipótesis propuesta.

Finalmente, dentro de las conclusiones, se apunta a tratar de estimular la continuidad en la investigación para propiciar el conocimiento, fortalecimiento y desarrollo sobre la norma de la Omisión Impropia, provocar la compilación de la normatividad nacional e internacional que sea útil para consulta de los operadores de justicia de tal manera que se pueda alcanzar el objetivo de ejecutar verdaderas defensas técnicas en amparo de la dignidad del Estado, de las Fuerzas Militares y de sus integrantes.

\section{EL PODER POLÍTICO Y LAS FUERZAS MILITARES}

En el marco de la misión constitucional de las Fuerzas Militares la seguridad y defensa nacional de la mano con el respeto de los Derechos Humanos y del Derecho Internacional Humanitario, son centro de gravedad, y su estudio y análisis ha sido motivo de controversia. En este sentido, recientemente se trató de materializar, en la Ley 684 de 2001 trascendentales temas que abarcan los conceptos de seguridad y defensa; sin embargo, fue declarada inconstitucional de acuerdo a lo expresado por el máximo Tribunal Constitucional en Sentencia C-251 de 2002. Luego se presentó el Acto Legislativo 02 de $2003^{6}$, que buscaba otorgar herramientas para la seguridad, pero este también sucumbió ante el análisis constitucional, como lo expreso la Sentencia C-816 de 2004. Con la aceleración del conflicto interno se impuso la llamada seguridad democrática, política gubernamental que diseñó la estrategia para combatir los grupos al margen de la ley, y que además se intentó incluir como política de Estado, pero esta idea, promovida por la bancada del partido del gobierno de turno (Partido de la U) tampoco tuvo cabida en el ambiente

\footnotetext{
${ }^{6}$ El Acto Legislativo 02 del 18 de diciembre de 2003, buscaba modificar los artículos 15, 24, 28 y 250 de la Constitución Política de Colombia. El Acto Legislativo fue declarado inexequible.
} 
político, pues entre las opiniones contradictorias más destacadas se distingue la de Alfredo Beltrán, ex magistrado de la Corte Constitucional, quien hace notar que "la Constitución Nacional tiene las bases en las que se establece que uno de los fines del Estado es la protección de todas las personas" (El Tiempo, 25 de septiembre de 2008, pp. 1-4). Recientemente, en la misma dirección se aprobó la Ley de Seguridad Ciudadana (Ley 1453 de 2011), con la que se intentan nuevos mecanismos para implementar la convivencia de la sociedad.

Se quiere resaltar aquí algunos apartes del contenido de las Sentencias C-251 de 2002 y C816 de 2004. De la primera, que estudió la constitucionalidad de la Ley 684 de 2001, es vital conocer y reflexionar sobre los análisis que hace el Tribunal Constitucional respecto a temas fundamentales que tienen cabida en el ámbito militar y que sin duda influyen en decisiones relacionadas con comportamientos omisivos o de acción. En la manifestación jurisprudencial se encuentra el debate de cómo la Ley 684 de 2001 que contenía las estrategias de seguridad y defensa, éstas indicaban desconocimiento del poder civil sobre la Fuerza Pública, se afectaba el mandato constitucional sobre las Fuerzas Armadas, se fracturaba el principio de separación de poderes, se perturbaba el pluralismo, y todo indicaba la marcha hacia un Estado totalitario.

En ese sentido, las anteriores conclusiones, si así se pueden llamar y se han interpretado correctamente, se derivan de las nociones que la ley en comento trataba de establecer en su contenido. De acuerdo a la providencia, uno de los conceptos que traía inserto la ley y que agredían la Constitución era el de poder nacional ${ }^{7}$. Escribió la Corte Constitucional en la Sentencia C- 251de 2002 que:

"No es posible determinar si ese poder nacional es simplemente una referencia a la capacidad funcional de los órganos estatales, o implica verdaderamente una nueva

\footnotetext{
${ }^{7}$ Según el art. $3^{\circ}$ de la ley acusada, el poder nacional es la "capacidad del Estado colombiano de ofrecer todo su potencial para responder ante situaciones que pongan en peligro el ejercicio de los derechos y libertades, y para mantener la independencia, la integridad, autonomía y la soberanía nacional en concordancia con lo establecido en los artículos $2^{\circ}$ y 95 de la Constitución Política" (cfr. Corte Constitucional, Sentencia C-251 de 2002).
} 
realidad institucional, como lo sugiere no sólo su alusión a todo el Estado, sino además el hecho de que la ley regula entidades que coordinan el poder nacional, como el Consejo Superior de Seguridad y Defensa."

Y concluye:

“(...) un examen atento de la Ley 684 de 2001 permite concluir que la figura del poder nacional no es una mera referencia a una capacidad de los órganos del Estado y de las instituciones ya existentes, sino que la ley busca, a pesar de no decirlo explícitamente, crear una nueva realidad institucional -el poder nacionalque tiene unas determinadas funciones, unos cometidos y unos órganos que la conforman."

Más adelante se extiende la línea que hace la Corte, entre la noción de poder nacional y la posible búsqueda de una nueva realidad institucional, la que argumenta con las funciones que se le atribuían al Consejo de Seguridad. Así se manifestó el Tribunal en la misma sentencia:

"Este consejo tiene una doble función: de un lado, según el artículo 12 es el órgano rector del Sistema de Seguridad y Defensa Nacional. Y de otro lado, según el artículo 13 le corresponde la "dirección, ejecución y coordinación de todos los elementos del Poder Nacional y su fortalecimiento, con miras a garantizar la Seguridad Nacional". A su vez, este consejo, que debe reunirse periódicamente, es presidido por el Presidente, quien, además, según el artículo 20, debe dirigir los campos del poder nacional."

También el extenso contenido conceptual de los objetivos nacionales ${ }^{8}$ es vinculado a la cadena de concepciones que se enlazan con el poder nacional; sin duda, al establecerse éstos, la consecución correspondería al Presidente, lo que conduciría al totalitarismo que antes se mencionaba. En la misma vía analiza la Corte Constitucional la llamada “Apreciación Político-Estratégica de Seguridad y Defensa Nacional”, documento básico del sistema de seguridad y defensa que contiene, entre otros, el análisis de las amenazas a las

\footnotetext{
8 “Objetivos Nacionales. Serán los definidos por el Presidente de la República teniendo en cuenta que como supremo deber y misión constitucional le corresponde diseñar y establecer los medios y mecanismos para hacer una Nación más segura y más próspera, particularmente en tres ámbitos: seguridad con efectiva diplomacia y con fuerzas militares listas para luchar y ganar, impulsar la prosperidad de la economía y promoción de la democracia" (cfr. Sentencia C-251 de 2002).
} 
cuales puede verse abocado el país en los campos político, económico, social y militar, lo que termina otorgándole el poder al Presidente en ese contexto que tenía la Ley 684 de 2001, desbordando normas constitucionales, pero muy especialmente la separación de poderes.

Hacia el terreno puramente militar se aterriza la noción del teatro de operaciones ${ }^{9}$ y las implicaciones que tiene al someter el poder civil al mando del militar que asuma el control de la zona de operaciones ${ }^{10}$. De igual manera las implicaciones que tenía la actividad de registro de la población civil en esas jurisdicciones, y de mayor consideración era la posibilidad de asignar funciones de policía judicial a las Fuerzas Militares.

Ahora bien: la Sentencia C-816 de 2004, como ya se afirmó, declaró la inconstitucionalidad del acto legislativo 02 del 18 de diciembre de 2003, el cual para enfrentar el terrorismo pretendía modificar los artículos 15, 24, 28 y 250 de la Constitución Política de Colombia. Si bien el acto legislativo decayó por vicios de procedimiento, es esencial destacar que los artículos que se buscaban modificar estaban directamente ligados con la intimidad de las personas y de sus familias, con la libertad de circulación y con la libertad individual en general, lo que indudablemente merecía un debate de alto nivel en los escenarios del Congreso, abordando temas en concreto como las facultades para la interceptación y registro de la correspondencia sin orden judicial, las restricciones a la libertad de locomoción, la ampliación de las condiciones para realizar detenciones, allanamientos y registros domiciliarios, y no menos problemático la ambivalencia en el cumplimiento de las

\footnotetext{
${ }^{9}$ El art. 54 de la Ley 684 de 2001 definió así el teatro de operaciones: "el área geográfica en donde, previo establecimiento de motivos fundados que hagan prever la posible amenaza o alteración del orden constitucional, la soberanía, la independencia y la integridad del territorio Nacional y se desarrollarán las operaciones militares que están contenidas en los Planes Estratégicos y Tácticos para el cumplimiento de la misión constitucional de la Fuerza Pública" (cfr. Sentencia C-251 de 2002).

${ }^{10}$ Dentro de esos elementos conceptuales esenciales que le da la ley al teatro de operaciones, está estrechamente vinculada: “(1) la figura del encargo de la ejecución de las órdenes presidenciales a los comandantes que asumen el control operacional del área, que tendrán imperativamente una prelación «inmediata y preferente» sobre las de gobernadores y alcaldes, y (2) la posibilidad de establecer medidas de control a los habitantes, y en especial la coordinación del registro de la población. Estos dos aspectos serán abordados de manera independiente" (cfr. Sentencia C-251 de 2002).
} 
funciones de la policía judicial, todo directamente relacionado con la misión de las Fuerzas Militares.

En este marco de leyes y jurisprudencias, irrumpen con relevancia las normas relativas a los Derechos Humanos y el Derecho Internacional Humanitario y no menos importante el Estatuto de Roma, estas normas cobran esa trascendencia por la situación de conflicto y las particulares formas inhumanas que aplican los grupos al margen de la ley, esta situación de conflicto hace indispensable que los miembros de la Institución Militar que ostenten la posición de garante, redefinan para la práctica en Colombia el marco conceptual del objetivo militar, de los principios de necesidad, proporcionalidad, distinción y dignidad humana, todo lo anterior, es lo que exige normas precisas aprobadas por un legislativo que conozca de las acciones de guerra que ejecutan los grupos al margen de la ley en el marco del conflicto colombiano.

La trascendencia de conocer desde los inicios los debates políticos y sus resultados, así como de conocer las manifestaciones de las Altas Cortes, además de que fijan normatividad legal, debe generar importantes reflexiones dentro de la Institución Militar que forjen los cambios doctrinales necesarios que direccionen el cumplimiento de la misión; sus reglamentos, manuales y actos administrativos ${ }^{11}$, deben apuntar a entregarle un marco funcional preciso, claro y concreto a los miembros de la institución castrense, ${ }^{12}$ al punto de que, de una parte se incremente la efectividad en la vigilancia y protección de los bienes jurídicos del Estado y de la Sociedad, y de otro lado que esa normatividad se

\footnotetext{
${ }^{11}$ LiBARDo RodríguEZ, en su Tratado de Derecho Administrativo, define el acto administrativo de manera general, así: "Son las manifestaciones de voluntad de la administración tendientes a modificar el ordenamiento jurídico, es decir, a producir efectos jurídicos. Por ejemplo, un decreto del Presidente de la República, una ordenanza departamental, un acuerdo municipal" (p. 195). Más adelante se refiere a los criterios posibles para calificar las funciones de los actos: los dos criterios clásicos, el formal y el material, adiciona luego un punto de vista funcional o jurisdiccional, y por último da lugar a un punto de vista jerárquico (p. 203).

${ }_{12}$ Es importante la lectura y análisis desde la óptica penal, de las implicaciones que tiene el Manual de Derecho Operacional de las FF.MM. de frente a la misión constitucional de las Fuerzas Militares, al que se hará referencia más adelante.
} 
constituya en verdaderas armas jurídicas defensivas que impidan que sus integrantes se vean involucrados en delitos contra la vida y la libertad individual. ${ }^{13}$

Lo anterior cobra importancia a la hora de aterrizar la responsabilidad penal de los militares en su condición de funcionarios públicos, dándolo sentido a lo expuesto por el maestro JAKOBS, quien refiriéndose a los deberes estatales en una de sus conferencias, escribió: “(...) si bien el Estado como persona jurídica no responde por sí mismo penalmente, sí en cambio los titulares de una función pública que actúan para él” (1998, p. 50). Frente a estas expresiones, como se verá más adelante, conviene señalar previamente que la normatividad internacional, la Constitución Política, la Ley y tales premisas de la doctrina son desarrolladas y aplicadas en su quehacer por las Altas Cortes. A manera de ejemplo el concepto de JAKOBS lo ensancha la honorable Corte Constitucional, así:

"El Estado puede ser garante -competencia institucional- cuando se trata de ciertos deberes irrenunciables en un Estado social y democrático de derecho. Por ejemplo, es irrenunciable la protección de la vida e integridad de todos los habitantes del territorio y la defensa de la seguridad interior y exterior de la Nación. Como el Estado no puede responder directamente en el campo penal, el juicio recae en el titular de la función correspondiente. (JAKOBS, citado en la Sentencia SU-1184 de 2001)."

\footnotetext{
13 Respecto de las llamadas coloquialmente capturas masivas, se extraen principalmente las siguientes expresiones de parte de la Oficina en Colombia del Alto Comisionado para los Derechos Humanos: “(...) En desarrollo de la política de seguridad del Estado, que persigue objetivos importantes, es crucial que estas medidas se implementen de conformidad con las normas de Derechos Humanos, así como que se fortalezca la presencia de las instituciones estatales civiles, y especialmente de los órganos de control encargados de la protección y promoción de los Derechos Humanos (...). También preocupa a la Oficina el hecho de que las aprehensiones de carácter masivo y las capturas individuales sin fundamento jurídico afecten, en no pocas ocasiones, a miembros de grupos vulnerables, como los constituidos por defensores de Derechos Humanos, líderes comunitarios, sindicalistas y pobladores de zonas en las cuales operan grupos armados ilegales. Al privar de la libertad a estas personas el Estado adopta procedimientos contrarios a los principios de igualdad y no discriminación, y permite que la intolerancia y los prejuicios contaminen las políticas de mantenimiento del orden público y prevención de la criminalidad. (...). Casos como los de Quinchía y Buenaventura, recientemente comentados también por los medios de comunicación, revelan hasta qué punto han llegado a ser perturbadoras prácticas como las descritas en el informe de la Alta Comisionada. En el municipio caldense se capturó, en una sola actuación, a 117 personas. Después de dos años se ha demostrado la plena inocencia de 111 de los ciudadanos privados de la libertad. En el municipio valluno fueron capturados, en un solo procedimiento, 52 pobladores. Tras dos años de cárcel 21 de ellos han sido exonerados por la Fiscalía General de la Nación (...)". (En: http://www.hchr.org.co. Naciones Unidas, Oficina en Colombia del Alto Comisionado para los Derechos Humanos, Bogotá, 17 de agosto de 2005.
} 
Este tipo de premisas, su rigidez y la coherencia con los artículos $2^{\circ 14}, 6^{\circ 15}, 90^{16}, 93^{17}$ $95.2^{18}, 122^{19}, 124^{20}, 209^{21}, 216^{22}, 217^{23}, 218^{24}, 189.3 .4 .5 .6 .^{25}, 305^{26}$ y $315.2^{27}$ de la

14 “Constitución Nacional, Artículo $2^{\circ}$. Son fines esenciales del Estado: servir a la comunidad, promover la prosperidad general y garantizar la efectividad de los principios, derechos y deberes consagrados en la Constitución; facilitar la participación de todos en las decisiones que los afectan y en la vida económica, política, administrativa y cultural de la Nación; defender la independencia nacional, mantener la integridad territorial y asegurar la convivencia pacífica y la vigencia de orden justo. Las autoridades de la república están instituidas para proteger a todas las personas residentes en Colombia, en su vida, honra, bienes, creencias, y demás derechos y libertades, y para asegurar el cumplimiento de los deberes sociales del Estado y de los particulares".

15 “Constitución Nacional, Artículo $6^{\circ}$. Los particulares sólo son responsables ante las autoridades por infringir la Constitución y las leyes. Los servicios públicos lo son por la misma causa y por omisión o extralimitación en el ejercicio de sus funciones".

16 “Constitución Nacional, Artículo 90. El Estado responderá patrimonialmente por los daños antijurídicos que le sean imputables, causados por la acción o la omisión de las autoridades públicas. En el evento de ser condenado el Estado a la reparación patrimonial de uno de tales daños, que haya sido consecuencia de la conducta dolosa o gravemente culposa de un agente suyo, aquél deberá repetir contra éste.

17 "Constitución Nacional, Artículo 93. Los tratados y convenios internacionales ratificados por el Congreso, que reconocen los Derechos Humanos y que prohíben su limitación en los estados de excepción, prevalecen en el orden interno. Los derechos y deberes consagrados en esta Carta, se interpretan de conformidad con los tratados internacionales sobre Derechos Humanos ratificados por Colombia".

18 “Constitución Nacional, Artículo 95.2. La calidad de colombiano enaltece a todos los miembros de la comunidad nacional. Todos están en el deber de engrandecerla y dignificarla. El ejercicio de los derechos y libertades reconocidos en esta Constitución implica responsabilidades. Toda persona está obligada a cumplir la Constitución y las leyes. Son deberes de la persona y del ciudadano: (...) 2. Obrar conforme al principio de solidaridad social, respondiendo con acciones humanitarias ante situaciones que pongan en peligro la vida o la salud de las personas (...)".

19 “ Constitución Nacional, Artículo 122. No habrá empleo público que no tenga funciones detalladas en la ley o reglamento y para proveer los de carácter remunerado se requiere que estén contemplados en la respectiva planta y previstos sus emolumentos en el presupuesto correspondiente".

20 "Artículo 124. La ley determinará la responsabilidad de los funcionarios públicos y la manera de hacerla efectiva".

21 “Constitución Nacional, Artículo 209. La función administrativa está al servicio de los intereses generales y se desarrolla con fundamento en los principios de igualdad, moralidad, eficacia, economía, celeridad, imparcialidad y publicidad, mediante la delegación y la descentralización de funciones. Las autoridades administrativas deben coordinar sus actuaciones para el adecuado cumplimiento de los fines del Estado. La administración pública, en todos sus órdenes, tendrá un control interno que se ejercerá en los términos que señale la ley".

22 "Constitución Nacional, Artículo 216. La Fuerza Pública estará integrada en forma exclusiva por las Fuerzas Militares y la Policía Nacional. Todos los colombianos están obligados a tomar las armas cuando las necesidades públicas lo exijan para defender la independencia nacional y las instituciones públicas. La ley determinará las condiciones que en todo tiempo eximen del servicio militar y las prerrogativas por la prestación del mismo".

23 "Constitución Nacional, Artículo 217. La nación tendrá para su defensa unas Fuerzas Militares permanentes constituidas por el Ejército, la Armada y la Fuerza Aérea. Las fuerzas armadas tendrán como finalidad primordial la defensa de la soberanía, la independencia, la integridad del territorio nacional, y del orden constitucional. La ley determinará el sistema de reemplazos en las Fuerzas Militares así como los ascensos, derechos y obligaciones de sus miembros y el régimen especial de carrera, prestacional y disciplinario, que les es propio".

24 “Constitución Nacional, Artículo 218. La ley organizará el cuerpo de policía. La Policía Nacional es un cuerpo armado permanente de naturaleza civil, a cargo de la Nación, cuyo fin primordial es el mantenimiento 
Constitución Nacional, así como los artículos $10^{28}, 20^{29}, 22^{30}, 25$ de la Ley 599 de 2000 (Código Penal Colombiano), el artículo 27 de la Ley 1407 de 2010 (nuevo Código Penal Militar), y en forma general la Ley 678 de $2001^{31}$, coloca a los militares frente a una tenaza jurídica que los obliga al conocimiento de la normatividad legal, para asegurar que sus procedimientos operacionales sean seguidos de procedimientos judiciales ceñidos a la ley, y no a la interpretación mediata de funcionarios que desconocen el arte militar y las circunstancias de tiempo, modo y lugar como se ejecuta y se enfrenta el conflicto, lo que

de las condiciones necesarias para el ejercicio de los derechos y libertades públicas, y para asegurar que los habitantes de Colombia convivan en paz. La ley determinará su régimen de carrera, prestacional y disciplinario".

25 "Constitución Nacional, Artículo 189. Corresponde al Presidente de la República como Jefe de Estado, Jefe de Gobierno, y Suprema autoridad Administrativa: (...) 3. Dirigir la Fuerza Pública y disponer de ella como Comandante Supremo de las Fuerzas Armadas de la República. 4. Conservar en todo el territorio el orden público y restablecerlo donde fuera turbado. 5. Dirigir las operaciones de guerra cuando lo estime conveniente. 6. Proveer a la seguridad exterior de la República, defendiendo la independencia y la honra de la nación y la inviolabilidad del territorio, declarar la guerra con permiso del Senado, o hacerla sin tal autorización para repeler una agresión extranjera; y convenir y ratificar los tratados de paz, de todo lo cual dará cuenta inmediata al Congreso (...)".

${ }^{26}$ “'Constitución Nacional, Artículo 305. Este artículo contiene las funciones generales de los gobernadores, pero extrañamente no aparece ninguna función específica y concreta relacionada con el mantenimiento del orden público. La relación con esta responsabilidad se establecería a partir del numeral uno de "cumplir y hacer cumplir la Constitución y las leyes...".

27 “Constitución Nacional, Artículo 315. Son atribuciones del Alcalde: (...) 2. Conservar el orden público en el municipio, de conformidad con la ley y las instrucciones y órdenes que reciba el Presidente de la República y del respectivo Gobernador. El Alcalde es la primera autoridad de policía del municipio. La Policía Nacional cumplirá con prontitud y diligencia las órdenes que le imparta el alcalde por conducto del respectivo comandante (...)".

28 “Código Penal Común, art. 10. Tipicidad. La ley penal definirá de manera inequívoca, expresa y clara las características básicas estructurales del tipo penal. En los tipos de omisión también el deber tendrá que estar consagrado y delimitado claramente en la Constitución Política o en la ley".

29 "Código Penal Común, art. 20. Servidores públicos. Para todos los efectos de la ley penal, son servidores públicos los miembros de las corporaciones públicas, los empleados y trabajadores del Estado y de sus entidades descentralizadas territorialmente y por servicios. Para los mismos efectos se consideran servidores públicos los miembros de la fuerza pública, los particulares que ejerzan funciones públicas en forma permanente o transitoria, los funcionarios y trabajadores del Banco de la República, los integrantes de la comisión nacional ciudadana para la lucha contra la corrupción y las personas que administren los recursos de que trata el artículo 338 de la Constitución Nacional".

30 “Código Penal Común, art. 22. Dolo. La conducta es dolosa cuando el agente conoce los hechos constitutivos de la infracción penal y quiere su realización. También será dolosa la conducta cuando la realización de la infracción penal ha sido prevista como probable y su no producción se deja librada al azar".

${ }^{31}$ La responsabilidad de los servidores públicos deviene de los arts. $6^{\circ}, 90,121$ y 124 de la Constitución Política. El artículo 90 de la Carta dice: "El Estado responderá patrimonialmente por los daños antijurídicos que le sean imputables por acción u omisión de las autoridades públicas". La ley de acción de repetición tiene una finalidad de interés público como es la protección integral del patrimonio de los ciudadanos, dirigida a garantizar la realización efectiva de los fines y propósitos del Estado Social de Derecho" (En: contraloriagen.gov.co). 
hace que la vulnerabilidad jurídica de los militares se incremente significativamente a la hora de enfrentar los juicios penales y disciplinarios.

La Constitución y la ley, los vaivenes políticos, las diversas manifestaciones del conflicto interno y de desorden público por los distintos actores de violencia, así como la necesidad de aplicar la normatividad sobre Derechos Humanos y Derecho Internacional Humanitario, hace necesario que el Estado brinde al militar las respectivas garantías constitucionales y legales que como servidores públicos les corresponde dentro del marco del Estado Social de Derecho, y no hacerlos beneficiarios de los derechos como ciudadanos de segundo orden, como se evidencia en el juego político con la figura del fuero militar, consagrado en el artículo 221 de la Constitución Nacional ${ }^{32}$, la cual ha sido pulverizada por la dirigencia política y desconocida en diversas situaciones por distintos operadores de justicia, en menoscabo directo del derecho sustancial y procesal penal.

HERnÁNDEZ MondRagón afirma, en uno de sus trabajos sobre el Derecho Internacional Humanitario y sobre su aplicación en Colombia, lo siguiente:

"En Colombia, la mayor parte de las discusiones sobre el tema en los años recientes se ha basado en criterios políticos. Siempre se ha discutido si conviene o no aplicarlo, con evidentes prejuicios políticos, sin adecuado conocimiento de las normas desde el punto de vista militarista, de un lado, y las perspectivas guerrilleristas o revolucionarias radicales, de otro, y que ponen las necesidades militares o las revolucionarias por encima de las humanitarias haciendo prevalecer aquellas sobre éstas, han sido los criterios determinantes de las decisiones (1994, p. 21).”

En esa dirección de la importancia paralela que tienen las funciones institucionales y el respeto a la dignidad humana, juega papel importante la preparación integral del militar para que intervenga activamente en las decisiones que atañen al bienestar general, al

\footnotetext{
32 “Constitución Nacional, Artículo 221. De los delitos cometidos por los miembros de la Fuerza Pública en servicio activo, y en relación con el mismo servicio, conocerán las Cortes Marciales o Tribunales Militares, con arreglo a las prescripciones del Código Penal Militar. Tales Cortes o Tribunales estarán integrados por miembros de la Fuerza Pública en servicio activo o en retiro".
} 
respecto, es válido retraer a LANDAZÁBAL REYES (1997, p. 75.), en sus Reflexiones sobre el Ejército Colombiano, donde escribió:

"En estos pueblos del tercer mundo, permanentemente hostigados por guerras internas de origen esencialmente político, de graves consecuencias, en las que se defienden democracias inmaduras o ficticias, en las que el poder se impone más por la arbitrariedad del régimen político, que por el imperio severo de la ley, el jefe militar que ignora la política, llegará a las posiciones de la más alta responsabilidad en el mando, con una mentalidad de gendarme, que habrá de impedirle el desempeño del verdadero papel estratégico en la conducción de sus fuerzas para el beneficio político del sistema de gobierno al que sirve con desprendimiento y con honor."

Este tipo de expresiones, una políticas y otras provenientes de militares concernientes al manejo de la guerra en el marco de las obligaciones constitucionales, generan en las relaciones civiles-militares desavenencias entre el campo político y el campo militar, precisamente por decisiones de los gobiernos de turno. Como ejemplos, en la administración $1982-1986^{33}$, en el Gobierno $1994-1998^{34}$, en el periodo $1998-2002^{35}$ y en el Gobierno 2002-2010 36 , hubo desacuerdos que generaron no sólo polémicas de carácter político, sino también otras de carácter militar, y no escapan las de orden jurídico. En el mismo sentido, la Revista Semana, en su edición 1513 de mayo de 2011 (pp. 36 y 37), hizo su propio resumen y análisis de las más frescas discrepancias entre civiles y militares, reseña la publicación de manera resumida, como el gobierno de Guillermo León Valencia retiro del servicio al General Ruiz Novoa por intento de golpe de Estado; El presidente Lleras Restrepo hizo lo propio con el General Pinzón Caicedo por cuestionar el

\footnotetext{
${ }^{33}$ La problemática del manejo de la retoma del Palacio de Justicia (ocurrida el 6 y 7 de noviembre de 1985), donde aun hoy se plantea la ausencia de la autoridad civil y/o el exceso de fuerza de los militares, entre otros aspectos.

${ }^{34}$ La inconformidad con su Comandante General de las Fuerzas Militares a raíz de los cuestionamientos que se le hacían al Presidente de turno, sobre la financiación de la campaña presidencial. La Corte Suprema de Justicia, Sala de Casación Penal, en el Proceso 22412 de 2007, no casó la sentencia que solicitó la defensa del Ex Ministro y se mantuvo la condena que le había sido impuesta por hurto agravado por la confianza.

35 Diferencias del Primer Mandatario con su Ministro de Defensa. Éste presentó su inconformidad al Presidente por el manejo que se le estaba dando a la entonces llamada zona de distensión, cuando se ejecutaba un proceso de paz. El Ministro fue seguido de algunos militares, los que a la postre fueron llamados a calificar servicios.

${ }^{36}$ La controvertida destitución de un Mayor General, dos Brigadieres Generales y otros oficiales por omisión en la presunta violación de Derechos Humanos (ejecuciones extrajudiciales).
} 
nombramiento de un civil al frente del presupuesto del Ministerio; López Michelsen considero que el General Valencia Tovar ejecutaba un liderazgo militar inconveniente y lo relevo del Comando del Ejército; Belisario Betancurt retiro del servicio al General Landazábal Reyes por que este manifestó en los medios de comunicación que "el país se acostumbraría a oír a sus generales"; el presidente Virgilio Barco motivo la salida del General Rafael Samudio por las diferencias entre los dos frente a la guerra sucia y al paramilitarismo; César Gaviria pasó a retiro al General Oscar Botero para dar paso al Ministro de Defensa Civil; el Presidente Ernesto Samper destituyó al General Harold Bedoya por razones de Estado, todo lo cual refleja las dificultades de esas relaciones civiles-militares en el más alto nivel, lo que con seguridad se irradia no solo en los subordinados sino en el producto de seguridad que recibe la sociedad.

Lo mencionado anteriormente no releva a los mandatarios en el orden nacional, regional y local dentro de la esfera organizacional del Estado, de las obligaciones que estipula el mandato constitucional y legal, relacionadas con el mantenimiento del orden público. MEndozA (1992, pp. 115,116), en el aparte relativo a Las Fuerzas Militares y el Estado, expresa:

"Las Fuerzas Militares establecidas con la finalidad expuesta de defensa de la soberanía, independencia, integridad territorial y orden constitucional, se articulan dentro del cuadro del Estado, bajo la dependencia de quien es su jefe, representante de la soberanía y símbolo de la unidad nacional, el Jefe de Estado. En un régimen parlamentario, su dependencia es del Rey o del Presidente y no del jefe de Gobierno. En un régimen presidencialista, por obvias consideraciones del Presidente de la República, pero en su atribución de Jefe de Estado y no de Gobierno. Por este motivo se entenderá que ni los gobernadores ni los alcaldes tienen autoridad de mandato sobre ellas".

La Constitución se refiere a dicha dependencia de -las Fuerzas Militares- con los verbos “dirigir" y "disponer”. Así, el art. 189-3 dice que "el Presidente dirige y dispone de la Fuerza Pública como Comandante Supremo de las Fuerzas Armadas de la República, y en el numeral 5 se refiere a que puede dirigir las operaciones de guerra cuando lo crea conveniente." En este mismo orden de ideas, las Sentencias C-048 de 2001 y C-251 de 
2002, entre otras, son reiterativas en la supremacía del poder civil y la subordinación del Estamento Militar a aquél. Sobre esta premisa no cabe discusión alguna, siempre y cuando se respete el marco de otros mandatos constitucionales y rumbos jurisprudenciales. Como ejemplo: si bien el artículo 189.3 de la Norma Superior constituye al señor Presidente de la República como comandante supremo de las Fuerzas Armadas, esta condición no la puede utilizar para que los militares actúen como instrumento de persecución política (C-251 de 2002), pues en el contexto de la separación de órganos del Estado, a pesar de la subordinación a que está sometida la Institución Castrense, otros organismos de control entrarían a interceder por el cumplimiento de las normas constitucionales, además de no estar obligados a realizar tal persecución.

Esta misma sentencia C-048 de 2001 que resolvió la problemática de desmilitarización de la entonces llamada "zona de distensión" "37, se refirió al tema de interés aquí tratado. La referida manifestación jurisprudencial, confronta entre otros, los artículos $2^{\circ}$ (intereses nacionales), 22 (derecho a la paz), 189 (atribuciones del señor Presidente) y 217 (Misión de las Fuerzas Militares) de la Carta Política, lo que permite entender un poco, algunas dificultades que en este problema de hacer o no hacer, de dirigir y disponer, de obedecer o no hacerlo, intervienen en el cruce funcional entre el presidente y las Fuerzas Militares. La Corte, entre otros aspectos, en la citada sentencia, manifestó:

"En efecto, al igual que la Constitución de 1886, la de 1991 consagra el principio de supremacía del poder civil sobre la función castrense, el cual se manifiesta en el otorgamiento de ciertas facultades al ejecutivo para determinar la estructura, organización y dirección de la fuerza pública. En este sentido, se mantiene la tradicional separación y la consecuente subordinación entre los poderes civil y militar. De hecho, los cuerpos sometidos a la disciplina militar, si bien tienen un pleno sometimiento a las autoridades civiles, tienen una doble relación con los órganos constituidos, esto es, de separación y de subordinación. Por ello, el ejecutivo tiene a su cargo el mantenimiento de la paz y del orden público interno, para lo cual tiene capacidad de adoptar las decisiones ordinarias y excepcionales

\footnotetext{
${ }^{37}$ En el periodo presidencial 1998-2002 se denominó zona de distensión al área del territorio nacional (más o menos 40.000 kilómetros cuadrados) que se desmilitarizó para dar paso al fallido proceso de paz con el grupo guerrillero autodenominado Fuerzas Armadas Revolucionarias de Colombia (FARC).
} 
del caso, puesto que en el Estado liberal democrático las fuerzas armadas jamás podrán decidir sobre la necesidad de un estado de excepción.

Esto es lo que precisamente explica la diferencia entre el poder de disposición y el poder de mando en las fuerzas armadas. El primero se refiere a las decisiones políticas, puesto que existe un ámbito de decisión política en la especialización y complejidad del manejo castrense. Por su parte, el poder de mando está limitado a la defensa, dirección y ejecución de labores, que están garantizadas por la disciplina y la organización jerárquica.

En síntesis, corresponde al Presidente la dirección de la administración militar y las políticas de defensa del Estado. Con base en esta atribución constitucional, ejerce su autoridad para ordenar, coordinar, dirigir la actuación de la fuerza pública, la definición de los grandes planteamientos de política militar y la determinación de la presencia o el retiro de las tropas en todo el territorio colombiano, lo que incluye las zonas destinadas a las negociaciones de paz. Por ello, no puede el estamento militar decidir la conveniencia del retiro o el retorno de la fuerza pública en las llamadas zonas de distensión. Esta es una atribución exclusiva del Presidente, y su inobservancia, por parte de la Fuerza Pública, genera graves consecuencias en el ámbito penal y disciplinario."

Mendoza Palomino (1992) también se refiere a la Norma Superior y a lo que él considera la dinámica de esas relaciones civiles-militares; se extiende en analizar un poco los verbos dirigir y disponer, los cuales hacen parte esencial del artículo 189.3 en cuanto al mandato que recibe el señor Presidente de la República como Comandante Supremo de las Fuerzas Armadas; de más trascendencia son estos mandatos de dirección y disposición cuando, en el numeral 5 del mismo artículo 189 de la Carta, aparece el precepto de dirigir las operaciones de guerra cuando lo estime conveniente; en este sentido, la dirección de las operaciones de guerra se puede debatir desde distintos puntos de vista. Para MENDOZA este precepto es discutible desde la óptica que se otorgue un mando efectivo de la tropa, con mayor razón cuando el Jefe de Estado es una persona inexperta en la estrategia militar, lo que conduce a una solución de diferenciar precisamente entre los conceptos de dependencia jerárquica y mando efectivo, y consecuencialmente las responsabilidades que a cada quien le atañen acordes a la norma y a su interpretación. 
La Institución Militar tiene en su haber suficientes acontecimientos referentes a la materia en discusión que han tenido la notabilidad nacional e internacional por los resultados. Lo que se quiere hacer distinguir es que las acciones militares, provengan o no de órdenes directas del señor Presidente, connotan conductas o comportamientos individuales y/o colectivos que se desarrollan en las zonas de operaciones, unas conductas planeadas rígidamente y otras no, unas con errores y otras no, sin embargo acorde con los resultados, son comportamientos de los cuales se ocupa el derecho penal. Se pueden citar algunos ejemplos con resonancia internacional: la llamada toma a Casa Verde ${ }^{38}$, la captura de Rodrigo Granda en Venezuela ${ }^{39}$, la captura de alias Simón Trinidad en Ecuador ${ }^{40}$, la operación desplegada contra el campamento del cabecilla "Raúl Reyes" también en Ecuador $^{41}$, y finalmente la denominada Operación Jaque ${ }^{42}$, entre otras. De otra parte, en el orden interno, ante el avance político-militar de las autodenominadas Fuerzas Armadas Revolucionarias de Colombia $(\mathrm{FARC})^{43}$, en la misión de neutralizar a los sediciosos, las exigencias de resultados operacionales a los militares ${ }^{44}$, los cuales originaron aciertos y errores, entre los cuales se distinguen: privación ilegal de la libertad ${ }^{45}$, especialmente aquellas que se dieron en el contexto de "capturas masivas", y las ejecuciones extrajudiciales ${ }^{46}$, que han sido denominadas por los medios de comunicación como "falsos positivos", que dieron lugar a múltiples denuncias contra los militares por homicidio

\footnotetext{
${ }^{38}$ Así se denominó la operación militar que fue lanzada el 09 de diciembre de 1990 contra el principal campamento que tenían los cabecillas de las autodenominadas Fuerzas Armadas Revolucionarias de Colombia.

${ }^{39}$ Se llevó a cabo el 13 de diciembre de 2004, después de lo cual se trabó la polémica de violación de soberanía con el gobierno de Venezuela.

${ }^{40}$ Realizada el 02 de enero de 2004.

${ }^{41}$ La operación militar se ejecutó el $1^{\circ}$ de marzo de 2008 en territorio del vecino país ecuatoriano, sin realizar coordinación alguna con las autoridades de ese país (¿violación de la Soberanía?).

${ }^{42}$ Así se llamó la operación ejecutada por las Fuerzas Militares el pasado 02 de julio de 2008, donde como resultado se rescataron 15 secuestrados. Se cuestionó, entre otros, el uso del emblema de la Cruz Roja Internacional.

${ }^{43}$ La Carpa (Guaviare), 1996, Las Delicias (Putumayo), 1996; Puerres (Cauca), 1996; Patascoy (Nariño), 1997; Mitú (Vaupés), 1998; El Billar (Caquetá), 1998; Secuestro Iglesia La María, Cali (Valle), 1999; Secuestro Diputados del Valle, Cali (Valle), 2002, entre otros.

${ }^{44}$ GERMÁN JiMÉnEZ (2010). El Tiempo.com, Sección Justicia, 21 de octubre de 2010.

45 “ Código Penal Común, Artículo 174. Privación ilegal de la libertad. El servidor público que abusando de sus funciones, prive a otro de su libertad incurrirá en prisión de tres a cinco años" (la pena fue agravada acorde con la Ley 890 de 2004).

${ }^{46}$ Así se han denominado algunos homicidios causados por miembros del Ejército Nacional, que sin haber ocurrido en combate fueron presentados como éxitos de la lucha antisubversiva.
} 
$\operatorname{agravado}^{47}$, homicidio en persona protegida ${ }^{48}$, desaparición forzada ${ }^{49}$, falsedad ideológica en documento público ${ }^{50}$, y hasta concierto para delinquir. ${ }^{51}$

Penetrar ahora ampliamente en el contexto del Derecho Internacional Humanitario es imposible, sin embargo urge hacer alguna revisión a la luz de la comunidad internacional, del ayer y el hoy del delito omisivo, dado que las amenazas en general se representan en distintas formas de ataque que se materializan en deferentes estrados judiciales. Ese avance de las embestidas jurídicas, así como el desarrollo de la concepción del concepto de Estado social de derecho que impone la nueva Constitución de 1991, hace imperativo que las Fuerzas Armadas de los Estados democráticos procuren revolucionarse y dar el respectivo giro en las tareas que han de asumir para contrarrestar los desafíos que le demandan, de una

47 “ Código Penal Común, Artículo 103. Homicidio. El que matare a otro incurrirá en prisión de trece a veinticinco años”. Las circunstancias de agravación están explícitas en el artículo 104 del mismo Estatuto. Se debe tener en cuenta que la pena fue agravada e acuerdo con la Ley 890 de 2004.

48 "Código Penal Común, Artículo 135. Homicidio en persona protegida. El que, con ocasión y en desarrollo de conflicto armado, ocasione la muerte de persona protegida conforme a los Convenios Internacionales sobre Derecho Humanitario ratificados por Colombia, incurrirá en prisión de treinta (30) a cuarenta (40) años, multa de dos mil (2.000) a cinco mil (5.000) salarios mínimos legales mensuales vigentes, e inhabilitación para el ejercicio de derechos y funciones públicas de quince (15) a veinte (20) años.

"Parágrafo. Para los efectos de este artículo y las demás normas del presente título se entiende por personas protegidas conforme al Derecho Internacional Humanitario: 1. Los integrantes de la población civil. 2. Las personas que no participan en hostilidades y los civiles en poder de la parte adversa. 3. Los heridos, enfermos o náufragos puestos fuera de combate. 4. El personal sanitario o religioso. 5. Los periodistas en misión o corresponsales de guerra acreditados. 6. Los combatientes que hayan depuesto las armas por captura, rendición u otra causa análoga. 7. Quienes antes del comienzo de las hostilidades fueren considerados como apátridas o refugiados. 8. Cualquier otra persona que tenga aquella condición en virtud de los Convenios I, II, III y IV de Ginebra de 1949 y los Protocolos Adicionales I y II de 1977 y otros que llegaren a ratificarse".

49 “ Código Penal Común, Artículo 165. Desaparición forzada. El particular que someta a otra persona a privación de su libertad cualquiera que sea su forma, seguida de su ocultamiento y de la negativa a reconocer dicha privación, de dar información sobre su paradero, sustrayéndola del amparo de la ley, incurrirá en prisión de veinte a treinta años, multa de mil a tres mil salarios mínimos legales mensuales vigentes y a interdicción de derechos y funciones públicas de diez a veinte años. A la misma pena quedará sometido el servidor público, o el particular que actúe bajo la determinación o la aquiescencia de aquel y realice la conducta descrita en el inciso anterior". Las circunstancias de agravación están explícitas en el artículo 1166 del mismo Estatuto, y se debe tener en cuenta la agravación de la pena acorde a la Ley 890 de 2004.

50 “ Código Penal Común, Artículo 286. Falsedad ideológica en documento público. El servidor público que en ejercicio de sus funciones, al extender documento público que pueda servir de prueba, consigne una falsedad o calle total o parcialmente una verdad, incurrirá en prisión de cuatro a ocho años e inhabilitación para el ejercicio de derechos y funciones públicas de cinco a diez años" (la pena fue agravada acorde a la Ley 890 de 2004).

${ }^{51}$ Código Penal Común, Artículo 340. Concierto para delinquir. Cuando varias personas se concierten con el fin de cometer delitos, cada una de ellas será penada, por esa sola conducta, con prisión de tres a seis años" (la pena fue agravada acorde a la Ley 890 de 2004). 
parte, para proveer la seguridad que reclaman los pueblos, y de otra, para evitar los errores y contener los ataques jurídicos y militares de sus adversarios.

Sin duda, la evolución del Derecho Internacional Humanitario y el cumplimiento de la misión de las Fuerzas Militares deben transitar por el mismo carril, pues el soldado, cada vez más conocedor y preparado en el tema humanitario contribuye, sin duda, a que la sociedad circule hacia el respeto entre sí. El devenir histórico permite observar un avance relativamente lento en el respeto al ser humano, a su dignidad humana; las guerras no dejan de presentar efectos humanitarios desastrosos: la Primera y Segunda Guerra Mundiales (el holocausto judío y los ataques a Hiroshima y Nagasaki), la Guerra de Corea, la Guerra de Vietnam, la llamada Guerra del Golfo, la Guerra de Los Balcanes (división de la antigua Yugoslavia), han tenido momentos de reflexión que han inspirado herramientas tendientes a neutralizar las acciones y omisiones en que pueden incurrir tanto los dirigentes políticos como los militares. Se pueden enunciar brevemente y sin rigurosidad histórica ni doctrinal, cómo SAndoval Mesa (2003) anuncia algunos antecedentes del Tratado de Roma: la propuesta en 1872 de Gustav MoINER, uno de los fundadores de la Cruz Roja Internacional para que se estableciera una corte permanente, en respuesta de los crímenes franco prusianos; el mismo autor se refiere al Tratado de Versalles luego de la Primera Guerra Mundial; "los tribunales de Núremberg y de Tokio para juzgar a los criminales de guerra de las potencias del eje", y posteriormente los tribunales ad hoc para la antigua Yugoeslavia y para Ruanda; trasciende la Declaración Universal de los Derechos Humanos en 1948, la cual, como lo expone el autor, surgen para el escenario de conflictos armados o fuera de ellos, y como si fuera poco, tal declaración genera la valoración de los bienes jurídicos que se originan a partir de la persona humana. La evolución se va haciendo más estricta y se pueden tener como referencia los 4 Convenios de Ginebra de $1949^{52}$. Finalmente en 1998 es aprobado el preámbulo del texto del Estatuto de Roma, del cual se

\footnotetext{
${ }^{52}$ En resumen: El primer convenio busca aliviar la suerte de los heridos y los enfermos de las Fuerzas Armadas en campaña; el segundo convenio es para aliviar la suerte de los heridos, los enfermos y los náufragos de las Fuerzas Armadas en el mar; el tercer convenio contiene normas relativas al trato debido a los prisioneros de guerra y sus derechos, y el cuarto convenio se refiere a la protección debida a las personas civiles en tiempo de guerra.
} 
resaltan las atrocidades que ha recibido la humanidad, la trascendencia de estos crímenes en el contexto de la paz global y en consecuencia la necesidad de que la misma comunidad mundial a través de sus representantes tome acción en cuanto al castigo de los responsables. (SANDOVAl Mesa, 2003, p. 63).

Como se anoto antes, sin penetrar en la normatividad internacional, debe anotarse que la particular situación del conflicto interno ${ }^{53}$ y la mixtura de los actores de este con las hoy llamadas bandas criminales, con los narcotraficantes, con la delincuencia organizada y con la delincuencia común, exige de una parte, que la clase política fije con seriedad directrices relacionadas con la seguridad y la defensa nacional, y de otro lado, que la Institución Militar haga su propio replanteamiento de reglamentos, manuales y protocolos en general, de tal manera que se acomoden a los conceptos de objetivo militar y sus implicaciones penales a la hora de seleccionarlo, o a la aplicación de los principios de necesidad, proporcionalidad y distinción desde el planeamiento de las operaciones hasta su ejecución, pues en esta ruta, se debe emprender la tarea de encontrar los alcances de estas figuras del Derecho Internacional Humanitario en la posición de garante que tienen los miembros de las Fuerzas Militares.

La trascendencia de estas generalidades, entre otras, tiene su punto gravitante en el análisis de las responsabilidades constitucionales y legales de la autoridad civil y la autoridad militar, la importancia de la seriedad en los procesos de suministro de alertas (informaciones) y toma de decisiones (Consejos de Seguridad) en el cumplimiento de los compromisos adquiridos, en ese gran contexto que gravitan los Derechos Humanos y el

\footnotetext{
${ }^{53}$ La sentencia C-291 de 2007 tiene el siguiente contenido: "1.1. Definición de "conflicto armado" para efectos de la aplicación del Derecho Internacional Humanitario.

El supuesto necesario para la aplicación del Derecho Internacional Humanitario es la existencia de un conflicto armado. La determinación de las condiciones que detonan la aplicación del Derecho Internacional Humanitario es, por lo mismo, necesaria para establecer el ámbito de aplicación de los tipos penales que se demandan en el presente proceso -ya que todos consagran conductas violatorias del DIH-, en tanto prerequisito de su adecuada interpretación y, en consecuencia, de la resolución de los problemas jurídicos planteados a la Corte.

La naturaleza voluble de los conflictos armados actuales ${ }^{53}$ ha llevado a la jurisprudencia internacional a definirlos como "el recurso a la fuerza armada entre Estados, o la violencia armada prolongada entre las autoridades gubernamentales y grupos armados organizados, o entre tales grupos, dentro de un Estado" ${ }^{\text {.". }}$
} 
Derecho Internacional Humanitario, (El artículo 214 de la Carta cuando se refiere a los estados de excepción dice que: "En todo caso se respetarán las reglas del Derecho Internacional Humanitario”.) y consecuencialmente el control no solo de los organismos domésticos, sino también el de la Corte Interamericana de Derechos Humanos en una condición subsidiaria ${ }^{54}$, y de otra la Corte Penal Internacional, en condición complementaria $^{55}$, en cuanto a los delitos que ha sistematizado y respecto de los sujetos activos de la conducta.

Entonces, el problema desde la óptica penal para las Fuerzas Militares es vertebral y requiere que se genere un verdadero sistema ofensivo - defensivo, es necesario el análisis de las distintas concesiones que hace la política en virtud a intereses nacionales y a veces a los mismos intereses políticos partidistas, como lo hizo notar HERNÁNDEZ MONDRAGÓN (1994), unas veces con dirección militarista y otras con perspectivas del guerrillerismo, o simplemente con el sentido de buscar electorado; en esta dirección, en el de las decisiones políticas y la ejecución funcional que compete a los militares, posiblemente las instituciones castrenses han desestimado la omisión de responsabilidades de otras autoridades (civiles y/o policiales) en distintos escalones, lo que termina sometiendo a la Institución Castrense, personificada en algunos de sus miembros, a infortunados escándalos judiciales y militares ${ }^{56}$. Luego, entre los miembros de la organización castrense, debe ser

\footnotetext{
${ }^{54}$ Cuando las investigaciones no avanzan se produce la demanda ante la Corte Interamericana de Derechos Humanos, sin que pierda competencia la justicia interna.

${ }^{55}$ La Corte Penal Internacional contempla delitos de genocidio, de lesa humanidad, de guerra y de agresión, y determina la responsabilidad penal individual cuando los Estados no han cumplido su deber de perseguir, juzgar y castigar a los responsables. Tiende a asegurar un verdadero acceso a la justicia y evitar así la impunidad.

${ }^{56}$ Se pueden citar algunos casos como el del Palacio de Justicia, el de Mapiripán, la emboscada de Puerres y el asalto a la Base de Patascoy. De los hechos del Palacio de Justicia, ocurridos en noviembre de 1985, aún hoy se realizan investigaciones por las acciones y posibles omisiones de parte de la autoridad militar, y se han condenado y se investigan altos oficiales por el posible desaparecimiento de algunas personas que al parecer salieron con vida luego de la operación de retoma por los militares. Los polémicos fallos han sido objeto de serios cuestionamientos, especialmente por las deficiencias probatorias. El manejo político y penal a la acción militar ejecutada en Jamundí (Valle) el 22 de mayo de 2006, donde resultaron muertos 10 policías y un particular. La operación de rescate de los secuestrados de la Iglesia de La María (30 de mayo de 1999) y las controvertidas órdenes políticas cuando se cumplían las operaciones en contra de los bandoleros. Los hechos de Puerres (Departamento del Cauca) donde fue emboscada una patrulla militar del Grupo Cabal, adscrito a la Tercera Brigada del Ejército, el 15 de abril de 1996. Los hechos del 02 de diciembre de 1997, relacionados con el asalto a la Base Militar de Patascoy (Departamento de Nariño), tropas orgánicas del Batallón Boyacá,
} 
motivo de sensata reflexión (obediencia debida vs. obediencia ciega) la línea recta que se traza entre la Constitución Nacional, lo que establece la Ley Penal, el amplio concepto de la misión institucional y la dirección política que reciba de la autoridad civil, en relación con los Derechos Humanos y el Derecho Internacional Humanitario; de esta manera, entre otras, se evita (omitir) cumplir directrices que se vislumbran fuera de la ley como la privación ilegal de la libertad, mal llamadas capturas masivas, y en el mismo sentido se debe generar responsabilidad y compromiso real de la autoridad civil respecto a la responsabilidad que se tiene cuando estas suministran informaciones sobre la puesta en peligro y ataque de los bienes jurídicos de la vida y la libertad individual ${ }^{57}$, lo que indudablemente amplifica el comprometimiento de los integrantes de la Institución Militar con las normas penales.

\section{EL DELITO DE OMISIÓN}

Para articular lo hasta aquí descrito sobre el esquema en que se perfila la presente aproximación al delito de omisión en las Fuerzas Militares, y habiendo escudriñado algunos señalamientos respecto del poder político, el poder militar y los derechos humanos y el derecho internacional humanitario, es preciso introducir nociones que tienen influencia y preponderancia en la corriente institucional y en la corriente jurídica.

Vale decir, que si se desvanece el conocimiento y práctica de la naturaleza de la Institución Militar, si se minimizan los instrumentos jurídicos que se deben conocer y aplicar, y no se busca materializar objetivamente la visión asociativa de Estado-Institución Militar y

\footnotetext{
descalabros operacionales que dieron lugar a una serie de acciones político-militares que apuntaron a menoscabar la credibilidad de la Institución Militar, como en el caso de Patascoy donde hubo decisiones del entonces Comandante de las Fuerzas Militares que reflejaban venganzas personales antes que hacer un direccionamiento serio y responsable del orden público como tema central de la Seguridad y De fensa nacional.

${ }^{57}$ Tómese como ejemplo los titulares del Noticiero de las 7:00 p.m. del Canal Caracol del 10 de septiembre de 2010: "Defensoría había advertido hace tres semanas sobre el riesgo de una incursión armada en ese mismo punto". Surgen, entre otras, las siguientes preguntas: ¿Cómo se hacen oficiales estas alertas tempranas? ¿De dónde proviene la información? ¿No son un engaño para llevar a los miembros de la Institución a una emboscada preparada por el enemigo, o simplemente un medio de distracción para evitar presión de las tropas en otro lugar?
} 
Sociedad, se apunta a que los integrantes de la Institución militar incurran con más frecuencia en omisiones y que sus administradores de justicia desemboquen en yerros a la hora de juzgar a los integrantes del Estamento Castrense. El Estado, la sociedad e Institución Militar pueden verse como los vértices del triángulo que compromete la misma naturaleza de la misión de las Fuerzas Militares, vista esta, de la manera más amplia posible. Se puede acuñar una misión a los militares para un Estado Social de Derecho, donde las exigencias en el campo funcional para éstos, son mayores que para los ciudadanos del común, precisamente por la situación de conflicto y las normas que rigen para enfrentarlo.

En este orden, se quieren resaltar los principios y valores de los que se vale la Institución Militar para edificar el denominado honor militar, por lo que se deben observar con cristal las indicaciones que contiene el artículo 24 del Régimen Disciplinario de las Fuerzas Militares (Ley 836 de 2003):

“Artículo 24. Valores Militares. La carrera militar exige depurado patriotismo, clara concepción del cumplimiento del deber, acendrado espíritu militar, firmeza de carácter, sentido de la responsabilidad, veracidad, valor, obediencia, subordinación, compañerismo y preocupación por cultivar y desarrollar en el más alto grado, los deberes y virtudes antes mencionadas.

Uno de sus pilares fundamentales es el honor militar, el cual es el conjunto de cualidades morales y profesionales que sustentan las virtudes castrenses del valor, lealtad, rectitud y decoro que colocan al militar en condiciones de aprecio dentro de la institución y la sociedad a que pertenece.

El respeto mutuo entre superiores y subalternos es obligación para todo el personal de las Fuerzas Militares, cualquiera que sea la repartición a la cual pertenezcan, el sitio donde se encuentren y el vestido que porten.

Los superiores tienen la obligación de servir de ejemplo y guía a sus subalternos, estimular sus sentimientos de honor, dignidad, lealtad y abnegación; fomentar su iniciativa y responsabilidad y mantenerse permanentemente preocupados por su bienestar. Deben además, inspirar en el personal confianza y respeto". 
De estos principios y valores se desprenden invariablemente, destacados vínculos con la codificación penal militar y ordinaria, el respeto a la dignidad humana, la trascendencia de la obediencia en ese régimen jerarquizado y de disciplina, el principio de confianza como eje de quienes ordenen un hacer o una omisión, o de quienes obedecen ordenes y las ejercen en el sentido estricto de la legalidad; estos principios y valores sin duda alguna tienen directa relación con esa amplia función del militar como garante de los bienes jurídicos de la vida y la libertad individual.

Si el conocimiento de la naturaleza de la Institución es gravitante, no es menos trascendental lo relativo a la visión instrumental tanto jurídica como militar, y en ese espacio se encuentran los delitos de omisión, los cuales no puede ser vistos desde la lupa de las apreciaciones que operan en el terreno de lo subjetivo y que por ende implican confusión, sino que en materia de derecho penal, esa visión debe ser enfrentada a la verdadera dinámica del conflicto interno y de desorden público y a las responsabilidades que se enfrentan con la normatividad sobre los Derechos Humanos y el Derecho Internacional Humanitario.

Luego de introducir los temas sobre la naturaleza de las Fuerzas Militares y la importancia de los instrumentos jurídicos y militares, se debe estampillar la visión asociativa Estado Fuerzas Militares ante los necesarios condicionamientos en Derechos Humanos y Derecho Internacional Humanitario que la comunidad internacional impone a los Estados, es indudable que las Fuerzas Militares de acuerdo al impacto que recibe y a sus capacidades, busca, como debe ser, crear posibilidades de juicios penales más objetivos e imparciales, lo cual no es posible sin la injerencia del Estado a través de sus organismos de control y la participación de la Sociedad, lo que hace que surja una veeduría interrelacionada que debe tener como único ganador el respeto, la vigilancia y la protección de los bienes jurídicos de los asociados.

Con estas bases, se analizaran brevemente las connotaciones que en derecho penal tienen los términos de acción y de omisión, los cuales trascienden las barreras de la simplicidad 
de las definiciones que tienen los vocablos en nuestro Diccionario de la Lengua Española: la acción como el "efecto de hacer", con los sinónimos de "acto, actividad y de hecho", la acción como "posibilidad de hacer alguna cosa" o tomada como la acción criminal y la omisión, dice el Diccionario, que es la "acción y efecto de omitir, olvido, dejadez, falta por haber omitido la ejecución de una cosa" (Círculo de Lectores, 1992).

Se puede afirmar que son conceptos diametralmente opuestos, pero en el campo penal, aunque se reconocen estas definiciones, el debate va mucho más allá por las mismas implicaciones que se le quieren dar desde el punto de vista punitivo. Así, por ejemplo: en citas de FORERO (2002) y AGUDELO (2002) la expresión “acción” quiso ser remplazada por "comportamiento voluntario" (VON HIPPEL); "realización de la voluntad" (MAYER); “comportamiento espontáneo” (RITTLER); “comportamiento humano” (MEZGER).

El mismo autor FORERO (2002, p. 3) hace notoria la contradicción de los conceptos de los maestros BELING y VON LISZT, así: mientras para BELING la omisión es no hacer nada, o intransitiva, para FRANZ VON LISZT es no hacer algo determinado, con lo cual este autor acuña un concepto transitivo de omisión, pues omisión no será no hacer nada, lo cual es un concepto indefinido, en absoluto, sino no hacer algo en concreto, como concepto transitivo. Se observan pues, al interior de la dogmática causalista, dos conceptos contrapuestos de omisión que son el intransitivo y el transitivo. FORERO se refiere a RADBRUCH, cuando este observaba la "imposibilidad de acuñar un concepto genérico que englobara la acción y la omisión”, al igual que el autor AGUDELo BETANCUR (2002, p. 35), analizando el concepto de acción en el esquema neoclásico citando a RADBRUCH, manifestó:

"Si la acción era un comportamiento positivo y la omisión un comportamiento negativo, la acción no podía abarcar los dos, ya que los dos conceptos estarían confrontados en su esencia misma. GUSTAV RADBRUCH dijo que así como es cierto que positivo y negativo y como A y no A, no pueden ser colocados bajo un concepto superior común, de la misma manera es cierto que la acción y la omisión tienen que permanecer independientes una junto a la otra; en sus propias palabras: acción y omisión se comportan como A y no A." 
De otra parte, estando el Estado colombiano adherido al Estatuto de Roma ${ }^{58}$, SANDOVAL MESA (2003, p. 88) incluye en su estudio la manera como la palabra conducta se extiende a los delitos de acción y de omisión, el autor se refirio al profesor RoDRÍGUEZ-VILLASANTE, del siguiente modo:

"En el tema de la definición de los delitos de la Corte, la palabra «conducta», empleada en el artículo 22 del Estatuto -principio de legalidad en su vertiente de tipicidad- fue cuidadosamente elegida para comprender no sólo los crímenes de acción -comportamiento positivo- sino también la conducta omisiva -son frecuentes los delitos de omisión dentro de los crímenes de guerra- y la comisión por omisión (artículo 28) que regula la responsabilidad de los jefes y otros superiores por no haber adoptado todas las medidas necesarias para prevenir los crímenes cometidos por sus subordinados."

En este sendero, y como adelante se analizará, ya el derecho patrio ha irrumpido para dejar en el mismo círculo la acción y la omisión, como ejemplo, MONTEALEGRE citando a JAKOBS en la Sentencia SU-1184 de 2001, dice “(...) que todos los problemas del Delito de Omisión son trasladables a la acción (...)", lo que también no deja de ser discutible en algunos delitos de mera conducta como la injuria y la calumnia.

En cuanto a los comportamientos omisivos, estos datan desde el Derecho Romano: "Los delitos de omisión más antiguos del Derecho Romano se referían al abandono de los deberes del cargo público" (HoNIG citado en JAKOBS, 1998, p. 9). El Derecho General Prusiano parece que era bastante general, pero a la vez estricto, al tratar los deberes de asistencia activa mutua, como lo señala el profesor JAKOBS (1998), al hacer la siguiente trascripción de la introducción de dicho derecho: "Cada miembro del Estado está obligado a fomentar el bienestar y la seguridad de la existencia común, según la relación de su posición social y patrimonio". En seguida, refiriéndose a CRISTIAN WOLF, transcribe cómo este interpretaba la utilidad común como meta del Estado:

\footnotetext{
${ }^{58}$ El gobierno colombiano expidió la Ley 742, y la Corte Constitucional, mediante Sentencia C-578 de 2002 , declaró exequible tanto la Ley como el Estatuto de Roma.
} 
(...) el hombre no está sólo obligado moralmente a servir de diversa forma con su patrimonio, su trabajo, su ayuda y su ejemplo, también jurídicamente, en existencia común, se debe cuidar de cómo se consigue que el otro ni emprenda lo que es contrario a la prosperidad común, ni omita lo que para estas es tenido por provechoso.

A esta expresión del Derecho Prusiano, afirmó JAKOBS (1998, pp. 9, 10, 11 y 12) que: “(...) le falta sin embargo, una teoría dogmático penal que pudiese restringir tal meta”, y considera que sobrevaloraba la comisión de la omisión. Más adelante, en la parte general del Derecho General Prusiano dice: "quien ni impide ni denuncia un delito grave inminente debe ser penado, cuando se le pueda probar que tenía conocimiento fidedigno del proyectado delito".

Los delitos de omisión en general no son de común ocurrencia en las jurisdicciones ordinaria y penal militar, son relativamente pocos los casos que se encuentran. Sin embargo su dinámica conceptual y de normativa en los códigos no avanza proporcional a la actividad social, y particularmente al ingenio de esta, para actuar u omitir conductas que los compromete con la ley penal. La existencia de una sociedad de riesgos hace que sean dos rieles los que se deben aparejar: el primero, la necesidad imperiosa de buscar que el ciudadano obre con más inteligencia para evitar acercarse a las normas penales (SÁNCHEZ HerrerA, 2002), y el segundo sería entonces, la necesidad de la velocidad legislativa en la actualización de los códigos, particularmente para los delitos de mayor impacto negativo en la sociedad, relacionados para el caso en estudio con omisiones que involucren los bienes jurídicos de la vida y la libertad.

Brevemente se puede explorar el contenido de los Códigos Penales Militares en cuanto a la omisión en general. El Código Penal Militar de 1988 (Decreto 2550), en el Título II, contempla como formas de realizar el delito la acción y la omisión, considerándose ejecutado al momento de la realización del comportamiento o de la omisión del mismo. Siendo este código de direccionamiento causalista, exige que el resultado sea consecuencia de la acción o de la omisión. En el artículo 18, referente a la causalidad, estipula claramente que "cuando se tiene el deber jurídico de impedir el resultado, no evitarlo pudiendo hacerlo, 
equivale a producirlo". Se hace énfasis en que el Estatuto de 1988 marcaba la diferencia entre los delitos y las faltas (artículo 15), y seguidamente manifestaba que "son delitos militares los descritos en este Código".

El Código Penal Militar de 1999 (Ley 522), en el mismo Título II, se refiere al hecho punible, y establece que los punibles cometidos por los miembros de la Fuerza Pública son los descritos en el Estatuto Penal Militar. Esta codificación de 1999 colocó expresamente a los miembros de la Fuerza Pública como sujetos del Código Penal Común (artículo 20), que se entiende como una concreción o ampliación de los artículos $4^{\circ}$ (prevalencia de la Constitución como Norma de Normas), $6^{\circ}$ (responsabilidad de los particulares y los servidores públicos) y 95 (deberes de los ciudadanos) de la Constitución Nacional, y dispone que sus integrantes también estén abrazados por las normas que adicionen o complementen los Códigos. Igualmente considera como formas de realización de la conducta la acción y la omisión, y se cree que el comportamiento punible se ejecuta en el momento que se lleva a cabo la acción, o en el momento en que debió haberse realizado la acción omitida. En lo que respecta a la causalidad, no presenta cambios respecto al Estatuto de 1988, pues de una parte exige que el resultado sea consecuencia de la acción o de la omisión, y de otra hace claridad respecto a la responsabilidad del servidor público cuando éste tiene el deber jurídico de impedir el resultado y no lo hace.

El Código de 1999 y el nuevo Código Militar (Ley 1407de 2010) contemplan que los miembros de la Fuerza Pública están sujetos a los hechos punibles descritos en el Código Militar y a los previstos "en el Código Penal Común y en las normas que los adicionen o complementen" (artículo 20 en las dos leyes). Sin embargo en las dos codificaciones los artículos 195 de la Ley 522 de 2000 y 171 de la Ley 1407 disponen que: "Cuando un miembro de la Fuerza Pública en servicio activo y en relación con el mismo servicio, cometa delito previsto en el Código Penal Ordinario o leyes complementarias, será investigado y juzgado de conformidad con las disposiciones del Código Penal Militar". 
El Estatuto Castrense deja claro que se puede incurrir en los delitos por "acción y por omisión" (artículo 21). Trascendente y para debate es la manera como el Nuevo Código Penal Militar (Ley 1407 de 2010), en el artículo 27, establece la Omisión Impropia también como norma general (tipo abierto o en blanco), la que difiere en algunos aspectos estructurales de lo que dispone el artículo 25 del Código Común. Si bien la conducta puede ser realizada por acción y por omisión, y se funda ésta en el deber jurídico de impedir un resultado que se encuentre tipificado, la norma contiene unos requisitos como los "recursos y medios disponibles" y el "ámbito propio de dominio", que deja expresa la posibilidad de que concurran causales de exclusión de responsabilidad, y finalmente impone que el sujeto debe tener a su cargo "la protección real y efectiva del bien jurídico protegido o la vigilancia de determinada fuente de riesgo conforme a la Constitución, la ley o los reglamentos". La norma militar difiere también del artículo 25, en cuanto solo protege los delitos que atenten contra la vida e integridad personal y la libertad individual.

En el Código Penal Común (Decreto 100 de 1980) la conducta omisiva se consideraba realizada en el momento en que debió tener lugar la acción omitida, aún cuando para la condena del hecho punible requiere de causalidad, es decir, el resultado del cual depende que la existencia de éste debe ser consecuencia de su acción u omisión. Sin embargo, continuaba el artículo 21: “Cuando se tiene el deber jurídico de impedir el resultado, no evitarlo, pudiendo hacerlo, equivale a producirlo".

El capítulo séptimo de la Culpabilidad, en su artículo 40, expresaba de manera importante que:

"No es culpable quien realice la acción u omisión por caso fortuito o fuerza mayor, o quien obre bajo insuperable coacción ajena, o quien realice el hecho con la convicción errada e invencible de que está amparado por una causal de justificación o, finalmente, quien obre con la convicción errada e invencible de que no concurre en su acción u omisión alguna de las exigencias necesarias para que el hecho corresponda a su descripción legal”. 
Es la razón para que el estudio de la culpabilidad tenga significación especial, son las mismas circunstancias de modo tiempo y lugar en que generalmente se ejecutan las operaciones militares, las que exigen conocimiento y dominio de las causales de ausencia de responsabilidad que contiene el artículo 32 del estatuto penal y sin lugar a dudas aquellas que son más afines a la justificación de las acciones militares.

Finalmente, para aclara la denominación de los tipos omisivos, como propios e impropios, se anota como Perdomo Torres, refiriéndose al delito de Omisión Impropia, en el nuevo Código Penal colombiano, dice que en la evolución de la dogmática penal, al interior de los delitos de omisión se "buscó una diferenciación cualitativa distinguiéndose así entre unos propios, y otros llamados, de forma poco acertada, impropios, es decir, el delito de Omisión ha sido entendido como una excepción" (Silva SÁnchez citado en Perdomo Torres, 2001, p. 16), haciendo manifiesta la inexistencia de diferencias entre los delitos de acción y de omisión en el ámbito de los delitos de organización, fundamentado en que "la expectativa defraudada es la misma, variando tan solo la forma de defraudación" (SÁNCHEZ-Vera GómeZ-Trelles, 1997, p. 187). Se extrae de lo anterior, que los delitos de omisión son de Omisión Propia y de Omisión Impropia; los primeros son conductas definidas expresamente en los Códigos Penal y Penal Militar, y los de Omisión Impropia o comisión por omisión son los que para el caso están administrando los artículos 25 de la Ley 599 de 2000 y 27 de la Ley 1407 de 2010.

\subsection{OMISIÓN PROPIA}

Es preciso hacer una reseña de los delitos de omisión propia, en este camino se debe especificar cuáles conductas se han tipificado en el Código Común y en el Código Militar, también en este recuadro se observan conflictos entre las dos jurisdicciones en el tipo penal de omisión de apoyo, donde algunos de los elementos que los componen difieren sustancialmente como se observará más adelante. 
El Estatuto Militar a través del Decreto 2550 de 1988, la ley 522 de 1999 y la ley 1407 de 2010, ha mantenido prácticamente los mismos tipos penales, relegando en las dos últimas reformas al Estatuto Común los tipos de prevaricato por omisión y abuso de autoridad por omisión de denuncia. No sucede lo mismo con el Código Común, en el cual con respecto al decreto 100 de 1980, se incluyeron las siguientes conductas: Omisión de Socorro (Art.131.) Omisión de Medidas de Socorro y Asistencia Humanitaria (Art.152.); Omisión de Medidas de Protección a la Población Civil (Art.161.); Omisión de Denuncia (Art.219B.); Omisión de Control (Art.325.); y Omisión de Agente Retenedor o Recaudador. (Art.402.).

Tipos penales como la Omisión de Medidas de Socorro y Asistencia Humanitaria, la Omisión de Medidas de Protección a la Población Civil, la Omisión de abastecimiento o la Omisión de Apoyo Especial, contemplados en el nueva normatividad penal, deben ser de conocimiento del militar en todos los niveles de mando, es frecuente que las autoridades civiles, la Policía y la sociedad estén requiriendo apoyos militares, los cuales por la escases de recursos y la frecuencia de alertas tempranas, merecen un debido proceso de análisis que le permita al Comandante Militar asegurarse en la decisión, para evitar sus límites con la justicia penal.

\subsubsection{La Omisión Propia en el Código Penal Militar.}

La sistematización de la omisión propia en los tres últimos códigos militares, (Decreto 2550 de 1988, Ley 522 de 1999 y Ley 14397 de 2010.) se refleja en tabla No 1; a manera de información se transcribe el contenido de los comportamientos omisivos que estableció el nuevo Código Penal Militar en la Ley 1407 de 2010:

Artículo 115. Omisión en el abastecimiento. El miembro de la Fuerza Pública legalmente encargado para ello que no abastezca en debida y oportuna forma a las tropas, para el cumplimiento de acciones militares o policiales, incurrirá en prisión de uno (1) a cinco (5) años de prisión. 
Si como consecuencia de la conducta anterior resultare algún perjuicio para las operaciones o acciones militares o policivas, la pena será de dos (2) a cinco (5) años.

Si la conducta se realiza por culpa, la pena se disminuirá hasta en la mitad.

Artículo 119. Cobardía por omisión. El que por cobardía en acción armada no acuda al lugar de la misma, debiendo hacerlo, o no permanezca en el sitio de combate, o se oculte, o simule enfermedad, incurrirá en prisión de cinco (5) a diez (10) años.

Artículo 145. Omisión en naufragio, catástrofe o siniestro. El comandante que en naufragio, catástrofe o siniestro, no agote los medios para conservar la disciplina o en caso de salvamento, no embarque a la tripulación y demás ocupantes, en las lanchas, botes o balsas disponibles, incurrirá en prisión de dos (2) a cinco (5) años.

Artículo 148. Omisión de auxilio. El que sin justa causa omita prestar auxilio pedido por buque, aeronave civil, militar o policial, nacional o de un país amigo, y aún de un país enemigo en los casos en que haya mediado promesa de rendición, incurrirá en prisión de tres (3) a seis (6) años.

Si por falta del auxilio solicitado se perdiere el buque o aeronave militar, policial o mercante con matrícula nacional, la pena se aumentará hasta en la mitad.

Artículo 149. Omisión de inutilizar buque, aeronave, carro de combate o medio de transporte colectivo de la Fuerza Pública. El comandante de un buque, aeronave, carro de combate o medio de transporte colectivo de la Fuerza Pública que después de haber agotado los recursos para defenderlo o salvar a los tripulantes, no lo inutilice o destruya para impedir que caiga en poder del enemigo, incurrirá en prisión de tres (3) a seis (6) años.

Artículo 158. Requisición con omisión de formalidades. El que practicare requisición sin cumplir las formalidades y sin que circunstancias especiales lo obliguen a ello, incurrirá en prisión de uno (1) a tres (3) años.

Artículo 166. De la omisión de apoyo especial. El que sin justa causa rehúse o demore indebidamente el apoyo pedido en la forma establecida por la ley, reglamentos, directivas, planes, circulares u órdenes, por el comandante de una fuerza, unidad, buque o aeronave, para prestar auxilio en operaciones de campaña o de control del Orden Público, incurrirá en prisión de dos (2) a cinco (5) años.

La pena prevista en el inciso anterior será de tres (3) a seis (6) años de prisión, si como consecuencia de la omisión de apoyo se produjeren perjuicios materiales para la Fuerza Pública, sin perjuicio de lo previsto para el caso del concurso de conductas punibles. 
Si el apoyo de que trata el inciso $1^{\circ}$ del presente artículo, se refiere a las solicitudes de las autoridades civiles, la pena imponible será prisión de uno (1) a cuatro (4) años.

\subsubsection{La Omisión Propia en el Código Penal Común}

A mas de que se conozcan los tipos penales que han sido traídos al estatuto ordinario por el legislador en el Decreto 100 de 1980 y en la ley 599 de 2000, los cuales aparecen en la Tabla No 2, se hace la transcripción de los que están vigentes y se añade una tabla esquemática que permite visualizar en cada uno de ellos, sus diferentes estructuras. (Tablas 3 al 12.)

Por el objeto del trabajo y las especiales circunstancias del conflicto interno, hay tipos penales que merecen atención: entre ellos, particularmente la omisión de medidas de socorro y asistencia humanitaria (Artículo 152 del Código Penal.) y la omisión de medidas de protección a la población civil (Artículo 161 del Código Penal.), son dos tipos penales de omisión propia que se registran específicamente con relación a personas y bienes protegidos por el derecho internacional Humanitario, lo que hace que merezcan detallado conocimiento y análisis en todos los niveles de mando, pues son frecuentes los requerimientos de las autoridades y/o de la población civil que acude a la autoridad militar en busca de protección de bienes jurídicos amenazados por las precisas circunstancias del conflicto interno.

\section{Los siguientes son los tipos penales vigentes de de omisión propia}

“Artículo 131. Omisión de socorro. El que omitiere, sin justa causa, auxiliar a una persona cuya vida o salud se encontrare en grave peligro, incurrirá en prisión de dos (2) a cuatro (4) años. (La pena fue agravada acorde a la Ley 890 de 2004).”

"Artículo 152. Omisión de medidas de socorro y asistencia humanitaria. El que, con ocasión y en desarrollo de conflicto armado y estando obligado a prestarlas, omita las medidas de socorro y asistencia humanitarias a favor de las 
personas protegidas, incurrirá en prisión de tres (3) a cinco (5) años y multa de cincuenta (50) a cien (100) salarios mínimos legales mensuales vigentes (la pena fue agravada acorde a la Ley 890 de 2004)."

Este tipo penal, consagrado entre los delitos contra personas y bienes protegidos por el derecho Internacional Humanitario, es de especial importancia por la relación directa que tiene con el conflicto interno, ya que las acciones de los grupos al margen de la ley hacen que permanentemente estén en peligro o siendo atacados los bienes jurídicos de la población civil, lo que hace que en el desarrollo de las operaciones de salvamento "socorro y asistencia humanitaria", para proteger los bienes jurídicos de todas aquellas personas y bienes protegidos por el Derecho Internacional Humanitario, se establezcan en ese nivel las particularidades de los que se pueden configurar como sujetos pasivos de la conducta, en virtud, especialmente del Artículo 3 Común a los Convenios de Ginebra y al Protocolo II adicional a los mismos convenios.

“Artículo 161. Omisión de medidas de protección a la población civil. El que con ocasión y en desarrollo de conflicto armado, estando obligado a hacerlo, omita la adopción de medidas para la protección de la población civil, incurrirá en prisión de cuatro (4) a ocho (8) años y multa de doscientos (200) a mil (1.000) salarios mínimos legales mensuales vigentes (la pena fue agravada acorde a la Ley 890 de 2004).”

La adopción de medidas de protección de la población civil es un imperativo en el marco del conflicto interno a que se obliga el Estado especialmente a través de la Institución castrense, la obligación tiene influencia internacional y tales medidas de protección abarcan a la población en general sin distingos de credo, raza o tendencia política, como lo dispone el Protocolo adicional II a los convenios de Ginebra. No es solo el mandato de acudir en caso necesario a proteger los bienes jurídicos que estén amenazados o atacados por los grupos al margen de la Ley, comprende también las medidas preventivas cuando estas así se requieran, de igual manera aquellas medidas de protección comprenden desde el planeamiento de operaciones, donde se impone la obligación de la práctica del principio de distinción, evitando a toda costa que la población civil sea involucrada en el conflicto o que sufra los horrores de la guerra. La estructura del tipo esta directamente ligado con la 
posición de garante del militar, solo que la legislación lo establece como de omisión propia para con su estructura facilitar no solo su entendimiento, sino inclusive alertar y prevenir a quienes pueden verse involucrados.

Se entiende aquí, que, por la magnitud del conflicto interno, la responsabilidad recae no solo sobre la autoridad militar sino también sobre la autoridad civil, no en vano es constitucionalmente la responsable del orden público; la necesidad de protección sobreviene de distintas aristas, puede ser expresada por la misma comunidad, por la autoridad civil, por la autoridad policial o por los mismos militares; en este entramado es indispensable la interacción de las Instituciones para que se evite incurrir en el tipo penal.

Como en la omisión de medidas socorro, paralelo al respeto a la dignidad humana y el principio de solidaridad como mandatos constitucionales, sobreviene el cumplimiento de los Convenios de Ginebra y sus protocolos, los cuales contienen especiales medidas de protección a la población civil.

Al respecto a la trascendencia de la población civil manifestó en la sentencia C-291 de 2007, lo siguiente:

\section{“3. EL PRINCIPIO DE DISTINCION}

\subsection{El postulado medular de protección de la población civil como fundamento del principio de distinción.}

El principio de distinción, que es una de las piedras angulares del Derecho Internacional Humanitario, se deriva directamente del postulado según el cual se debe proteger a la población civil de los efectos de la guerra, ya que en tiempos de conflicto armado sólo es aceptable el debilitamiento del potencial militar del enemigo $^{59}$. El principio de protección de la población civil tiene carácter medular

\footnotetext{
59 Ver, CHETAIL, Vincent: "The contribution of the International Court of Justice to International Humanitarian Law". En: International Review of the Red Cross, Vol. 85 No. 850, Junio de 2003: "La distinción entre el combatiente y el no combatiente es la piedra angular de todo el derecho humanitario. Este principio básico se deriva del axioma que provee el fundamento mismo del derecho internacional humanitario, a saber, que únicamente es aceptable en tiempos de conflicto armado el debilitamiento del potencial militar del enemigo" [Traducción informal: "The distinction between combatant and non-combatant is the cornerstone of all humanitarian law. This basic principle derives from the axiom that is the very
} 
para el Derecho Internacional Humanitario. Según lo ha explicado el Consejo de Seguridad de las Naciones Unidas, "las partes en los conflictos armados tienen la responsabilidad primordial de adoptar todas las medidas posibles para asegurar la protección de los civiles afectados". " En palabras de la Asamblea General de las Naciones Unidas, "las poblaciones civiles tienen una necesidad especial de mayor protección en épocas de conflictos armados" 61 , y "todos los Estados y las partes en los conflictos armados tienen el deber de proteger a los civiles en los conflictos armados de conformidad con el derecho internacional humanitario", 62

El Protocolo Adicional II consagra el principio general de protección de la población civil en su formulación general en su artículo 13-1, así: "Artículo 13. Protección de la población civil. 1. La población civil y las personas civiles gozarán de protección general contra los peligros procedentes de operaciones militares"; y precisa que "para hacer efectiva esta protección, se observarán en todas la circunstancias las normas siguientes” - es decir, las sub-reglas específicas en las que se manifiesta el principio de distinción. El principio general de protección de la población civil en el ámbito de los conflictos armados internos también se consagra en otros tratados vinculantes para Colombia."

"Artículo 219B. Omisión de denuncia. El que por razón de su oficio, cargo o actividad, tuviere conocimiento de la utilización de menores para la realización de cualquiera de las conductas previstas en el presente capítulo y omitiere información a las autoridades administrativas o judiciales competentes sobre tales hechos, teniendo el deber legal de hacerlo, incurrirá en multa de diez (10) a cincuenta (50) salarios mínimos legales mensuales vigentes (la pena fue agravada acorde a la Ley 890 de 2004).

Si la conducta se realizare por servidor público, se impondrá, además la pérdida del empleo."

"Artículo 325. Omisión de control. El empleado o director de una institución financiera o de cooperativas que ejerza actividades de ahorro y crédito que, con el fin de ocultar o encubrir el origen ilícito de dinero, omita el cumplimiento de alguno o todos los mecanismos de control establecidos por el ordenamiento jurídico para las transacciones en efectivo incurrirá, por esa sola conducta, en

foundation of international humanitarian law, namely that only the weakening of the military potential of the enemy is acceptable in time of armed conflict."]

${ }^{60}$ Resolución 1674 del 28 de abril de 2006, el Consejo de Seguridad de las Naciones Unidas

${ }^{61}$ AGNU, Resolución 2675 (1970), sobre Principios Básicos para la protección de las poblaciones civiles en los conflictos armados, adoptada por unanimidad.

${ }^{62}$ AGNU, Resolución 59/171 del 20 de diciembre de 2004. 
prisión de dos (2) a seis (6) años y multa de cien (100) a diez mil (10.000) salarios mínimos legales mensuales vigentes.

“Artículo 402. Omisión del agente retenedor o recaudador. El agente retenedor o auto retenedor que no consigne las sumas retenidas o auto retenidas por concepto de retención en la fuente dentro de los dos (2) meses siguientes a la fecha fijada por el Gobierno Nacional para la presentación y pago de la respectiva declaración de retención en la fuente o quien encargado de recaudar tasas o contribuciones públicas no las consigne dentro del término legal, incurrirá en prisión de tres (3) a seis (6) años y multa equivalente al doble de lo no consignado sin que supere el equivalente a los cincuenta mil (50.000 salarios) mínimos legales mensuales vigentes.

En la misma sanción incurrirá el responsable del impuesto sobre las ventas que, teniendo la obligación legal de hacerlo no consigne las sumas recaudadas por dicho concepto, dentro de los dos (2) meses siguientes a la fecha fijada por el Gobierno Nacional para la presentación y pago de la respectiva declaración del impuesto sobre las ventas.

Tratándose de sociedades u otras entidades, quedan sometidas a esas mismas sanciones las personas naturales encargadas en cada entidad del cumplimiento de dichas obligaciones.

Parágrafo. El agente retenedor o auto retenedor, responsable del impuesto a las ventas o el recaudador de tasas o contribuciones públicas, que extinga la obligación tributaria por pago o compensación de las sumas adeudadas, según el caso, junto con sus correspondientes intereses previstos en el estatuto Tributario, y normas legales respectivas, se hará beneficiario de resolución inhibitoria, preclusión de investigación, o cesación de procedimiento dentro del proceso penal que se hubiera iniciado por tal motivo, sin perjuicio de las sanciones administrativas a que haya lugar (la pena fue agravada acorde a la Ley 890 de 2004)."

“Artículo 414. Prevaricato por omisión. El servidor público que omita, retarde, rehúse o deniegue un acto propio de sus funciones, incurrirá en prisión de dos (2) a cinco (5) años, multa de diez (10) a cincuenta (50) salarios mínimos legales mensuales vigentes, e inhabilitación para el ejercicio de los derechos y funciones públicas por cinco (5) años (la pena fue agravada acorde a la Ley 890 de 2004).”

Acerca del prevaricato por omisión, es importante partir de lo escrito por MARTÍNEZ LóPEZ (2002, p. 145) respecto al concepto del acto propio de la función pública: 
"Acto propio de una función pública, es el que por ley o reglamento está adscrito a la competencia funcional de servidor público y éste tiene el deber legal de realizarlo. Puede tratarse de acto material, como capturar un delincuente; o acto intelectual, como proferir una sentencia; o acto material e intelectual como recepcionar un testimonio."

Los verbos omitir, rehusar, retardar, denegar y la diversidad, de sus sinónimos, que determinan la conducta, son lo suficientemente amplios para enmarcar el comportamiento que requiere de investigación. Es importante considerar, entre otros, las implicaciones que tiene lo relativo a las acciones de ejecutar o no la captura de un delincuente, o de capturarlo y no colocarlo a disposición de la autoridad competente ${ }^{63}$, y de las circunstancias en que se coloque en libertad un individuo ${ }^{64}$, e igualmente los alcances legales que se tienen cuando se decomisa material y este no es puesto a disposición de las autoridades pertinentes ${ }^{65}$, o cuando un militar no actúa contra el enemigo como debía de hacerlo ${ }^{66}$, eventos que han sido ventilados en la jurisdicción militar. En cuanto a la captura de personas, como comportamiento que ataca precisamente el derecho a la libertad ${ }^{67}$, el cual ha sido suficientemente debatido, entre otros, a raíz de las ya citadas capturas masivas, es legítimo tener en cuenta aquí que en ocasiones el militar, y especialmente aquel de menor graduación, no tiene los elementos de juicio o la formación jurídica para valorar las exigencias que impone la ley a la hora de actuar u omitir frente al derecho de la libertad y/o de la vida. Se puede citar como ejemplo la denominada Operación Fénix ejecutada el $1^{\circ}$ de marzo de 2008, donde fue abatido alias "Raúl Reyes" miembro de las autodenominadas FARC, donde la Corte Suprema de Justicia (18 de mayo de 2011) invalidó algunas pruebas recolectadas en esa acción militar por distintas razones, entre otras, el incumplimiento de

\footnotetext{
${ }^{63}$ Cfr. Tribunal Superior Militar, radicado No 149523-6745-066-PONAL M.P. Mayor Jacqueline Rubio Barrera, Mayo de 2006.

${ }^{64}$ Cfr. Tribunal Superior Militar, radicado No 150489-4015-XIII-427, Providencia No 194, M.P. Mayor ® Yesid Santofimio Murcia, Diciembre 2006.

${ }^{65}$ Cfr. Tribunal Superior Militar, radicado No 149202-9767-XI-567-0017/02-03-04/PONAL, M.P. Mayor ® Imelda Triviño Lopera, Marzo de 2004. Tribunal Superior Militar, radicado No 090-144270-5693-2006-PNC, M.P. Teniente Coronel Tulia Clemencia González Pérez, junio de 2006.

${ }^{66}$ Cfr. Tribunal Superior Militar, radicado No 149964-ARC-6783-2709, M.P. Coronel® Jorge H. Barrios Garzón, Agosto de 2004.

${ }^{67}$ Artículo 24, C.N.: "Todo colombiano, con las limitaciones que establezca la ley tiene derecho a circular libremente por el territorio nacional, a entrar y salir de él y a permanecer y residenciarse en Colombia".
} 
normas relativas a la cadena de custodia. Se cuestiona, entonces, que si para una operación de esta importancia no se previó y se cumplió la normatividad, no mucho se puede esperar en aquellas que participan mandos medios.

La Sala de Casación Penal (Proceso 18850 de 2003) se ha pronunciado reiteradamente en su jurisprudencia respecto a este tipo penal, así:

"Según lo describe el artículo 414 de la Ley 599 de 2000, el delito de prevaricato por omisión se configura cuando el servidor público omita, retarde, rehúse o deniegue un acto propio de sus funciones.

Evidentemente y como corresponde a la definición del tipo básico de prevaricato, omitir, retardar, rehusar o denegar, deben ser actos realizados deliberadamente al margen de la ley, esto es con violación manifiesta de ella. Por tanto, la simple demostración objetiva de la adecuación aparente del hecho en alguno de los verbos que alternativamente configuran la ilicitud, no es suficiente para pregonar su punibilidad."

El Tribunal Superior Militar, en el Radicado 149523-6745-066-PONAL, que resuelve un recurso de apelación en un caso policial, relacionado con la privación de la libertad y el decomiso de una carne, en el que ni las personas ni el material fueron puestos a disposición de la autoridad competente, refiriéndose al aspecto subjetivo del prevaricato por omisión, reseña algunas manifestaciones de la Corte Suprema de Justicia, así:

“3.2. Ahora, en su aspecto subjetivo y dado que la conducta de prevaricato por omisión es delito eminentemente doloso, necesario se torna partir del concepto de dolo que, conforme la dogmática penal, es «el saber y querer la realización del tipo»y, en términos del art. 36 del C. Penal de 1980, vigente para la época de los acontecimientos, existe dolo cuando el agente realiza la conducta tipificada en la ley sabiendo que lo hace y queriendo llevarla a cabo, y también cuando la acepta previéndola al menos como posible, de lo cual se sigue que el dolo está integrado por dos componentes, tanto en los tipos comisivos como omisivos, uno intelectual, cognitivo o cognoscitivo y otro volitivo.

3.2.1. El primer momento comprende el conocimiento que se tiene del hecho punible -el tipo en su aspecto objetivo- en tanto que con el segundo se precisa de que el agente también quiera la realización del tipo, esto es, que tenga voluntad de concurrir a la conducta omisiva. 
No en vano viene sosteniendo la Corte que no toda omisión o retardo en el cumplimiento de un acto propio de las funciones asignadas, constituye delito de prevaricato por omisión, pues siendo este delito esencialmente doloso, requiere necesariamente que cualesquier conducta de las descritas en el artículo 150 del Código Penal de 1980 -art. 414 de la Ley 599 de 2000-, esté precedida del conocimiento y voluntad claros de faltar a la lealtad debida en el ejercicio de dicha función. Ello implica, en cada caso, la necesidad de examinar la norma que la asigna y el término para su cumplimiento y, además, es preciso demostrar si conociendo dichos presupuestos, medió en el agente la voluntad para omitir, rehusar, retardar o denegar el acto propio de esa función. Por consiguiente, para la realización del tipo penal de que se trata, el agente debe conocer y querer las circunstancias del hecho a que se refiere el mismo, "porque no es posible concebir el dolo sin el conocimiento y la voluntad del supuesto amenazado con pena. (Cfr. Proveídos del 28 de septiembre de 1993 y 18 de mayo de 1999, Rads. 8250 y 11726, M.P.: Dídimo Páez Velandia).”

En los hechos que tuvieron lugar en el asalto a la base militar de Patascoy (Departamento de Nariño), ocurrida el 21 de diciembre de 1997, donde se presentó el homicidio y secuestro de varios integrantes del Ejército Nacional, se estudió la figura del prevaricato por omisión, donde precisamente se analizaron aspectos puramente militares como los obstáculos naturales que brinda la topografía, las condiciones atmosféricas y la dotación impuesta de personal y material en el lugar de los hechos, ${ }^{68}$ lo cual a todas luces, desdibuja cualquier posibilidad de configurar la figura del dolo como elemento del prevaricato.

"Artículo 417. Abuso de autoridad por omisión de denuncia. El servidor público que teniendo conocimiento de la comisión de una conducta punible cuya averiguación deba adelantarse de oficio no dé cuenta a la autoridad, incurrirá en multa y pérdida de empleo o cargo público. La pena será de dos (2) a cuatro (4) años de prisión si la conducta punible que se omitiere denunciar sea de las contempladas en el delito de la omisión de denuncia de particular (la pena fue agravada acorde a la Ley 890 de 2004)."

Básicamente, como lo escribe MARTínEZ LóPEZ (2002, p. 167): “Consiste en no informar a la autoridad respectiva (Fiscalía) sobre hechos constitutivos de conducta punible, investigable de oficio, cuyo conocimiento adquirió por cualquier medio, un servidor

\footnotetext{
${ }^{68}$ Así lo determinó la Fiscalía 19 Penal Militar en los folios 2640 a 2662, en el proceso que se adelantó por los hechos de Patascoy en el departamento de Nariño.
} 
público. En otros términos incumplir el deber legal de denuncia penal, impuesto a los residentes en Colombia, mayores de dieciocho años".

Por el sólo hecho de omitir la denuncia de una conducta punible de la que tuvo conocimiento, la norma lo hace acreedor a una multa y de la pérdida del empleo o cargo público, pero el último inciso asigna una pena de dos a cuatro años de prisión si la conducta que se omite es de las relacionadas en el artículo 441, de omisión de denuncia de particular, esto es, los “delitos de genocidio, desplazamiento forzado, tortura, desaparición forzada, homicidio, secuestro, secuestro extorsivo o extorsión, narcotráfico, tráfico de drogas tóxicas, estupefacientes o sustancias psicotrópicas, enriquecimiento ilícito, testaferrato, lavado de activos, cualquiera de las conductas contra personas y bienes protegidos por el Derecho Internacional Humanitario o de las conductas de proxenetismo cuando el sujeto pasivo sea un menor de doce (12) años (...)".

En cuanto a los servidores públicos el tipo penal se refuerza, por así decirlo, con los artículos $2^{\circ}$ y $6^{\circ}$ de la Constitución Nacional. El doctor MolinA ARRUBLA hace notar además la importancia que tiene dentro del estudio de esta norma el contenido del artículo 27 inciso segundo del C.P.P., donde dice: "El servidor público que por cualquier medio conozca de la comisión de una conducta punible que deba investigarse de oficio, iniciará sin tardanza la investigación si tuviere competencia para ello; en caso contrario, pondrá inmediatamente el hecho en conocimiento de la autoridad competente".

Es significativo resaltar que por lo general los Comandantes militares con jurisdicción frecuentemente y por las funciones que cumplen están conociendo tipos penales consignados en el artículo 441, lo que indica una obligatoriedad de formular las respectivas denuncias.

Artículo 424. Omisión de apoyo. El agente de la Fuerza Pública que rehúse o demore indebidamente el apoyo pedido por autoridad competente, en la forma establecida por la ley, incurrirá en prisión de uno (1) a cuatro (4) años e 
inhabilitación para el ejercicio de derechos y funciones públicas por cinco (5) años (la pena fue agravada acorde a la Ley 890 de 2004).

Este tipo doloso, de sujeto activo cualificado -miembro de la Fuerza Pública- está claramente definido, y dentro de esta denominación se encuentran naturalmente inmersos los integrantes de las Fuerzas Militares y de la Policía Nacional, conforme al artículo 216. La relación que tiene este artículo 424 con el texto del artículo 186 del Código Penal Militar, generó una demanda de inconstitucionalidad, la cual fue resuelta en la Sentencia C-1184 de 2008, la impetración sustentada básicamente en la vulneración de los "Artículos $158^{69}, 169^{70}$ y $221^{71}$ de la Constitución Política, al desconocer supuestamente el principio de unidad de materia y el fuero militar, consagrados en esas normas", pues, con algunas diferencias en su estructura, en la Codificación Militar, artículo 166, se consagra la omisión de apoyo especial ${ }^{72}$, y el Estatuto Ordinario en el artículo $424^{73}$ establece la omisión de apoyo, por lo que se reclamaba en la demanda que esa conducta era del resorte exclusivo de los militares.

Ante la demanda, el Tribunal Constitucional declara exequible el artículo 424 de la Ley 599 de 2000, sin perjuicio de la aplicación de otros tipos penales, cuando los hechos constituyan

\footnotetext{
${ }^{69}$ Constitución Política, art. 158. "Principio de Unidad de materia en proyectos de ley. Todo proyecto de ley debe referirse a una misma materia y serán inadmisibles las disposiciones o modificaciones que se relacionen con ella. El presidente de la respectiva comisión rechazará las iniciativas que no se avengan con este precepto, pero sus decisiones serán apelables ante la misma comisión. La ley que sea objeto de reforma parcial se publicará en un solo texto que incorpore las modificaciones aprobadas".

${ }^{70}$ Constitución Política, art. 169. "Título y contenido de las leyes. El título de las leyes deberá corresponder precisamente a su contenido, y a su texto precederá esta fórmula".

${ }^{71}$ Constitución Política, art. 221. "Justicia Penal Militar. De los delitos cometidos por los miembros de la fuerza pública en servicio activo, y en relación con el mismo servicio, conocerán las cortes marciales o tribunales militares, con arreglo a las prescripciones del Código Penal Militar. Tales cortes o tribunales estarán integrados por miembros de la fuerza pública en servicio activo o en retiro".

72 “Código Penal Militar, Artículo 166. De la omisión de apoyo especial. El que sin justa causa rehúse o demore indebidamente el apoyo pedido en la forma establecida por la ley, reglamentos, directivas, planes, circulares u órdenes, por el comandante de una fuerza, unidad, buque o aeronave, para prestar auxilio en operaciones de campaña o de control del Orden Público, incurrirá en prisión de dos (2) a cinco (5) años".

73 “Código Penal Común, Artículo 424. Omisión de apoyo. El agente de la Fuerza Pública que rehúse o demore indebidamente el apoyo pedido por autoridad competente, en la forma establecida por la ley, incurrirá en prisión de uno (1) a cuatro (4) años e inhabilitación para el ejercicio de derechos y funciones públicas por cinco (5) años" (la pena fue agravada acorde a la Ley 890 de 2004).
} 
delitos de mayor gravedad, en otros términos, puede anotarse que el artículo 166 se aplica para aquellos delitos cometidos por militares en servicio activo y que la conducta tenga relación con el mismo servicio, y el artículo 424 tiene alcance en delitos que no se relacionen con el servicio. Siguiendo la línea jurisprudencial, corresponde a los que no cumplen el elemento objetivo del fuero.

De la redacción de los dos tipos, se observa cómo el artículo 424 del Código Común contiene un sentido más amplio en sus elementos descriptivos, cuando se refiere a la autoridad competente como la solicitante del apoyo; se entiende que puede ser la autoridad civil o la autoridad militar la que pide el apoyo, en cambio en el artículo 166 del Código Militar la solicitud del apoyo se circunscribe sólo a los comandantes militares que allí se enuncian. Se le suma a la discusión de los dos tipos penales que el artículo 424 exige que la autoridad competente realice el requerimiento de acuerdo a lo establecido por la ley, luego habría que recurrir a las normas que estén establecidas para solicitar tales apoyos, y el artículo 166 de la codificación castrense exige que los comandantes militares que soliciten el apoyo deben conocer la ley, los reglamentos, las directivas, los planes, las circulares y las órdenes propias de cada institución (Ejército, Armada, Fuerza Aérea). Del contenido de las dos normas emerge comúnmente que la autoridad civil y militar conozca la ley, luego para solicitar tales apoyos de parte de las autoridades locales, departamentales y nacionales, habrá lugar a acudir a protocolos que permitan la correcta toma de decisiones.

Artículo 441. Omisión de denuncia de particular (modificado por el artículo $9^{\circ}$ de la Ley 733 de enero 29 de 2002). El que teniendo conocimiento de la comisión de delitos de genocidio, desplazamiento forzado, tortura, desaparición forzada, homicidio, secuestro, secuestro extorsivo o extorsión, narcotráfico, tráfico de drogas tóxicas, estupefacientes o sustancias psicotrópicas, enriquecimiento ilícito, testaferrato, lavado de activos, cualquiera de las conductas contra personas y bienes protegidos por el Derecho Internacional Humanitario o de las conductas de proxenetismo cuando el sujeto pasivo sea un menor de doce (12) años, omitiere sin justa causa informar de ello en forma inmediata a la autoridad incurrirá en prisión de dos (2) a cinco (5) años.

La pena se aumentará en la mitad para el servidor público que cometa cualquiera de las anteriores conductas de omisión de denuncia. 


\subsection{LA OMISIÓN IMPROPIA}

Como se reseñó con anterioridad, JAKOBS, refiriéndose a la imputación penal de la acción y de la omisión, resaltó que: "los delitos de omisión más antiguos del Derecho Romano se referían al abandono de los deberes del cargo público" (HONIG citado en JAKOBS, 1998, p. 9); en la actualidad son los servidores públicos (autoridad civil y militar) quienes reciben el peso de la normatividad que articula los delitos de omisión impropia y en este caso específico los relacionados contra la vida y la libertad expresados en el artículo 25 de la Ley 599 de 2000 y en el nuevo Código Penal Militar (Ley 1407 de 2010).

La omisión impropia también refleja notoriamente debates en la academia y el registro que ha hecho el poder legislativo tanto en el código común, como en el penal militar, de igual se destaca la manera otros países registran en su normatividad la omisión impropia, se resalta a continuación cómo la Sala de Casación Penal (Radicado 25536 de 2006.), resolviendo la situación de garante que un juez ostentaría con relación a la custodia de los títulos de depósito judicial, luego de hacer el recorrido legislativo del artículo 25 de la Ley 599 de 2000 (Código Penal), señalo cómo los siguientes países conciben y plasman en sus leyes el delito de comisión por omisión. El Alto Tribunal hace referencia, así:

El artículo 13 del Código Penal Alemán. "Comisión por omisión. Quien omita evitar un resultado que pertenezca al tipo de una ley penal, sólo incurre en un hecho punible conforme a esta ley, cuando debe responder jurídicamente para que el resultado no se produzca, y cuando la omisión es equivalente a la realización del tipo legal mediante una acción".

El artículo 40 del Código Penal de Italia. “(...) No impedir un resultado, que se tiene la obligación jurídica de evitar, equivale a ocasionarlo".

El artículo 11 del Código Penal de España. “(...) Los delitos o faltas que consistan en la producción de un resultado sólo se entenderán cometidos por omisión cuando la no evitación del mismo, al infringir un especial deber jurídico del autor, equivalga, según el sentido del texto de la ley, a su causación. A tal efecto se equiparará la omisión a la acción: 
”a) Cuando exista una específica obligación legal o contractual de actuar.

"b) Cuando el omitente haya creado una ocasión de riesgo para el bien jurídicamente protegido mediante una acción u omisión precedente."

El numeral 2 del artículo 10 del Código Penal de Portugal. "La realización de un evento mediante omisión es punible solo cuando sobre el omitente recae la obligación personal de evitar tal resultado".

El artículo 8 del Código Penal de Eslovenia de 1995. “(1) El delito puede ser cometido mediante acción o mediante omisión. (2) Se incurre en delito omisivo solamente cuando el autor no ha desplegado una acción que tenía el deber jurídico de cumplir. (3) También se comete delito por omisión cuando, ante la ausencia de un tipo omisivo expreso, el autor no impide la producción de un resultado prohibido. En tal caso el autor es punible solo si jurídicamente está obligado a impedir el resultado y si la omisión corresponde a la realización del tipo legal mediante una conducta activa".

El reciente Código Penal de Croacia (1997). (...) También desarrolla el punto en el numeral (2) de su artículo 25: "El delito es cometido mediante omisión, cuando el autor, que está obligado jurídicamente a impedir el resultado del ilícito previsto en la ley, omite hacerlo y tal omisión por efectos y significado es igual a la comisión del delito por medio de una conducta activa"

En línea similar, se pronuncia el inciso $2^{\circ}$ del artículo 18 del Código Penal de Costa Rica (1970): "Cuando la ley reprime el hecho en consideración al resultado producido, responderá quien no lo impida si podía hacerlo, de acuerdo con las circunstancias, y si debía jurídicamente evitarlo".

El Código Penal del Ecuador de 1938 asumía el tema de la siguiente forma: "Artículo 12. No impedir un acontecimiento, cuando se tiene la obligación jurídica de impedirlo, equivale a ocasionarlo".

El artículo 13 del Código Penal del Perú (de 1991) es del siguiente tenor: 
El que omite impedir la realización del hecho punible será sancionado:

1. Si tiene el deber jurídico de impedirlo o si crea un peligro inminente que fuere propio para producirlo; y

2. Si la omisión corresponde a la realización del tipo penal mediante un hacer.

La pena del omiso podrá ser atenuada".

Y el artículo 3 del Código Penal del Uruguay (1889-1934), afirma:

Nadie puede ser castigado por un hecho previsto por la ley como delito, si el daño o el peligro del cual depende la existencia del delito, no resulta ser la consecuencia de su acción o de su omisión. No impedir un resultado que se tiene la obligación de evitar, equivale a producirlo.

SILVA SÁNCHEZ (2004, pp. 211 y 212), en sus Estudios sobre los Delitos de Omisión, tratando la regulación de la comisión por omisión por el sistema de clausula general, además de referirse a la cláusula española (ya transcrita), apunta que las siguientes legislaciones contemplan la norma: Alemania, Austria, Italia, Portugal, y que países como Francia e Inglaterra no la tienen. Las transcribe, así:

Austria: el Artículo dice "Comisión por Omisión. Si la Ley conmina bajo pena la causación de un resultado, será también punible el que omita evitarlo, a pesar de estar vinculado a ello por el ordenamiento jurídico en virtud de una obligación que recae especialmente sobre él y la comisión de evitación del resultado es equiparable a una realización del tipo legal por un hacer"

Ahora bien, en Colombia la Omisión Impropia ha venido evolucionando de tal manera que se visualiza la diferencia de su estructura, no sólo con los países antes relacionados, sino entre la Ley 599 de 2000 y la normatividad del Código de 1980.

El artículo 25 de nuestro Código Penal estructura la Omisión Impropia, así:

"Quien tuviere el deber jurídico de impedir un resultado perteneciente a una descripción típica y no lo llevare a cabo, estando en posibilidad de hacerlo, 
quedará sujeto a la pena contemplada en la respectiva norma penal. A tal efecto, se requiere que el agente tenga a su cargo la protección en concreto del bien jurídico protegido, o que se le haya encomendado como garante la vigilancia de una determinada fuente de riesgo, conforme a la Constitución o a la ley. Son constitutivas de posiciones de garantía las siguientes situaciones:

1. Cuando se asuma voluntariamente la protección real de una persona o de una fuente de riesgo, dentro del propio ámbito de dominio.

2. Cuando exista una estrecha comunidad de vida entre personas.

3. Cuando se emprenda la realización de una actividad riesgosa por varias personas.

4. Cuando se haya creado precedentemente una situación antijurídica de riesgo próximo para el bien jurídico correspondiente.

Parágrafo. Los numerales $1^{\circ}, 2^{\circ} 3^{\circ}$ y $4^{\circ}$ sólo se tendrán en cuenta en relación con las conductas punibles delictuales que atenten contra la vida e integridad personal, la libertad individual, y la libertad y formación sexuales".

Finalmente se destaca aquí cómo el Nuevo Código Penal Militar (Ley 1407 de 2010) también ha venido desarrollando y buscando la perfección de la estructura de la norma sobre la Omisión Impropia como norma general (tipo abierto o en blanco) que incluye en su estructura elementos que deben ser motivo de estudio.

La norma general expresa:

Artículo 27. Acción u omisión. La conducta punible puede ser realizada por acción u omisión.

El miembro de la fuerza pública que tuviere el deber jurídico de impedir un resultado perteneciente a una descripción típica, cuente con los recursos y medios disponibles y no actuare estando en posibilidad de hacerlo dentro de su ámbito propio de dominio, quedará sujeto a la pena contemplada en la respectiva norma penal, si no concurriere causal de exclusión de responsabilidad. A tal efecto se requiere que tenga a su cargo la protección real y efectiva del bien jurídico protegido o la vigilancia de determinada fuente de riesgo, conforme a la Constitución, la ley o los reglamentos. 
Parágrafo. La posición de garante solo se tendrá en cuenta en relación con las conductas punibles que atenten contra la vida e integridad personal y la libertad individual.

Construir el delito de omisión impropia es relativamente complejo, pues son pocos los ejemplos concretos existentes en doctrina del delito de comisión por omisión relacionado directamente con las acciones u omisiones de las Fuerzas Militares al interior del conflicto colombiano interno. Jurisprudencialmente se han debatido en los estrados judiciales hechos notorios en la vida nacional, que tienen que ver con la violación de los Derechos Humanos y del Derecho Internacional Humanitario (casos Mapiripan (SU 1184 de 2001) y La Gabarra (Proceso 24448 de 2007).

PERDOMO, refiriéndose a la comisión por omisión, escribe:

"En resumen, consideramos que la inexistencia de un precepto regulador de la comisión por omisión es totalmente sostenible desde perspectivas del principio de legalidad, pues los supuestos de comisión por omisión son idénticos en el plano normativo de las estructuras de imputación a los supuestos de la realización activa de los mismos (2001a, p. 20).”

O como escribe FORERO RAMÍREZ: "algunos autores se conforman con la posición de garante de un sujeto para endilgarle el resultado que no evitó; otros, en cambio, exigen algo más que la posición de garante" (2002, p. 55).

De otra parte la probabilidad del resultado por la acción omitida tiene su propio debate, sobre este punto de vista, está difundida la idea de que en la comisión por omisión es bastante una conexión probabilística, es decir, que la acción omitida hubiera impedido el resultado con probabilidad cercana a la certidumbre, criterio que es acogido en forma generalizada en la literatura.

Según JeSCHECK (2003) en la comisión por omisión no cabe requerir, como en el hacer positivo, una certeza plena respecto a la casualidad, dado que el examen de la misma no 
puede basarse en un suceso real, sino únicamente posible que no puede calcularse con seguridad.

Por su parte, MIR PUIG (1996) indica que no cabe decidir con absoluta seguridad si la acción omitida hubiera impedido o no el resultado, al tratarse de un juicio hipotético sometido inevitablemente a un margen de error, por lo que la doctrina dominante se conforma con la constatación de que la realización de la conducta debida hubiese evitado el resultado con probabilidad rayana en la certidumbre.

En el Código Común, para imputar una omisión a un miembro de la Institución Militar es imprescindible ir más allá de la aplicación generalizada del artículo 217 de la Carta, como lo expreso Montealegre (SU 1184 de 2001.) es necesario además de reflejar las capacidades en concreto para edificar la posición de garante, se requiere la valoración de la tipicidad, la antijuridicidad y la culpabilidad ${ }^{74}$.

De las capacidades del garante se hará referencia más adelante, en cuanto al estudio de la tipicidad se debe que se encuentran casos en que se pretende sobrepasar esta exigencia con sólo citar el artículo del derecho patrio y la norma o normas internacionales (bloque de

\footnotetext{
${ }^{74} \mathrm{La}$ existencia de esa posición de garante significa que el título de imputación se hace por el delito de lesa humanidad, o en general por las graves violaciones a los Derechos Humanos, sin importar la forma de intervención en el delito (autoría o participación), o el grado de ejecución del mismo (tentativa o consumación), o la atribución subjetiva (dolo o imprudencia). Las estructuras internas de la imputación no modifican la naturaleza del delito realizado; éstas no cambian porque el interviniente (para el caso, quien omite) se limite a facilitar la comisión de un hecho principal, o porque no se alcance la consumación del hecho.

En efecto: i) el autor y el partícipe intervienen en un hecho único, porque el destinatario de la imputación es el colectivo que lo realiza; el cómplice y el determinador no realizan un injusto autónomo, porque el delito efectuado les pertenece a todos en conjunto; la diferencia entre autoría y participación es cuantitativa y no cualitativa $^{62}$; ii) en la tentativa por omisión el garante retarda dolosamente la acción de salvamento o ésta no hubiera evitado la producción del resultado, el injusto del hecho sólo se diferencia de la consumación cuantitativamente, por el grado de desarrollo de la infracción de la norma, porque también exige los elementos de la imputación del delito consumado: la creación del riesgo jurídicamente desaprobado y la realización del riesgo, y iii) el conocimiento del riesgo (que sirve para deslindar el dolo de la imprudencia ) no modifica la naturaleza de la conducta realizada (la grave violación a los Derechos Humanos). Es decir, en todos los casos mencionados hay unidad del título de imputación, lo que no implica, desde luego, que verificada la posición de garante se estructure inmediatamente la responsabilidad, porque ésta presupone la reunión de todos los elementos del delito, a saber: tipicidad, antijuridicidad y culpabilidad (cfr. Sentencia SU1184 de 2001).
} 
constitucionalidad) que pueden intervenir en la conducta en estudio, agregándole una u otra línea jurisprudencial a veces incoherente con la figura penal de la omisión y con el caso concreto. Lo que se exige es buscar las pruebas que se ajusten a la demostración de la posición de garantía, a la tipicidad de la conducta en el tipo objetivo y subjetivo: el sujeto activo, el sujeto pasivo, el objeto material y el dolo, entre otros aspectos. No menos trascendente es, en este juicio de tipicidad, que el acusador conozca y sepa de la aplicación en el campo de combate de los reglamentos y manuales militares. A esta rigurosidad es que se refiere ZAFFARONI cuando sostiene que "El tipo siempre exige un juicio de valor", y anota adelante, que "El mismo simplismo que redujo al tipo a mera descripción, dedujo de ello que la acción típica es valorativamente neutra por que el tipo no expresa desvalor y que el juicio de tipicidad es meramente fáctico (...)", y hace expresa alusión a lo que el autor denomina los "elementos interpretables y las remisiones valorativas del comportamiento" (ZAFFARONI, 2006, p. 342), aspecto donde en la práctica de hoy, con frecuencia, se evidencian las deficiencias a la hora de hacer tal evaluación. Si la tipicidad, como la expresa el artículo 10 del Estatuto debe estar definida “(...) de manera inequívoca, expresa y clara (...)”, así como para los tipos omisivos, “(...) el deber tendrá que estar consagrado y delimitado claramente en la Constitución Política o en la ley", luego le es exigible al operador jurídico desplegar su capacidad de investigación para reflejar la tipicidad de la conducta en la acusación, pues no es poca la exigencia de los elementos estructurales y normativos que dispone el artículo 25 como norma general o tipo en blanco, en esta dirección es fundamental el conocimiento del arte militar pues para solo citar un ejemplo son variados los casos en que, en razón a las estratagemas ${ }^{75}$, que se ejecutan en las acciones de los grupos al margen de la ley, pueden quedar muchos vacíos en las decisiones de acciones militares que limitan con el presupuesto normativo, como en el caso del dolo, es decir que la infracción penal sea prevista como probable y su no producción se deje al azar, o como en el caso de la culpa en el recuadro de la infracción al deber objetivo de

\footnotetext{
${ }^{75}$ La palabra estratagema, del griego strategeman, que significa "ardid de guerra, engaño o astucia", es cubrir con un velo el verdadero fin que se pretende (cfr. Reglamento de Operaciones en Combate Irregular, p. 140). También se define como: "el empleo planeado de acciones con el único fin de que el enemigo cometa errores, esta es la guerra maestra del «engaño», es la esencia de las tácticas de lucha. Consiste en el empleo de ardides que deslumbran los ojos y atrapan sus víctimas casi sin sentirlo" (Escuela de Relaciones Civiles y Militares. T. I, 1998, p. 24).
} 
cuidado en un análisis ex post, considerando que para el funcionario militar era predecible la acción que atacó los bienes jurídicos de la población ${ }^{76}$.

Ahora bien, en cuanto a la figura en el Código Castrense de 2010 (Ley 1407), la redacción del tipo contiene, del mismo modo, algunos elementos que es importante resaltar. Por obvias razones, el en el marco de la omisión, registra que la posición de garante sólo se tendrá en cuanto a los comportamientos que atentan contra la vida e integridad personal y la libertad individual, excluye, en comparación con el Código Común, los comportamientos contra la libertad y formación sexuales.

De igual manera se consideran inmersas en la norma castrense otras condiciones que conciernen al garante, lo cual más que una novedad, debería ser una realidad en la estructura y contenido del Código Penal, se quiere decir que los tipos penales debe incluir en su estructura elementos normativos que indiquen el marco de las funciones en que se puede incurrir en las conductas, finalmente la misma Constitución dispone (Artículo 122) que no habrá empleo público que no tenga funciones detalladas en la ley o reglamento, lo que tiene directa relación precisamente con los Reglamentos y manuales Militares que indican, dirigen y regulan las acciones de los militares en el entrenamiento y en la guerra.

Quizá por esta razón hace referencia indirecta a ciertos aspectos que un buen conocedor del arte militar los debe explotar para el debate jurídico, como los siguientes:

a) Debe contar con los recursos y medios disponibles.

b) Que tenga a su cargo la protección real y efectiva del bien jurídico protegido o la vigilancia de determinada fuente de riesgo.

c) Debe estar en posibilidad de actuar dentro de su ámbito propio de dominio.

\footnotetext{
${ }^{76}$ En la Sentencia SU-1184 manifestó el Tribunal Constitucional: "Bien puede acontecer que el garante (a quien se le imputa un delito de lesa humanidad) no sea responsable penalmente por ausencia de dolo (no conocía el riesgo concreto para los bienes jurídicos) o imprudencia (el riesgo para los derechos fundamentales no le era cognoscible), o que exista un estado de necesidad justificante por colisión de deberes (frente a dos agresiones simultáneas a sectores de la población, sólo podía proteger una sola), etc.”.
} 
d) Si no concurriere causal de exclusión de responsabilidad.

Teniendo como plataforma la norma general del artículo 25 de la Ley 599 de 2000, la norma militar (artículo 27) no difiere en lo esencial. Se estipula hacia dónde va dirigido el deber de actuar y se exige de distinta manera las capacidades funcionales, materiales y territoriales (contar con recursos y medios disponibles); la posibilidad de actuar dentro de su ámbito de dominio, (dominio de acción y voluntad.) tal como lo consagra el Código Militar, enmarca la variedad de las capacidades, el ámbito de dominio no es otro que el desarrollo de las funciones constitucionales, legales y reglamentarias impuestas para la jurisdicción asignada (competencia territorial), y en este cerco se deriva el empleo de los recursos humanos y materiales puestos a su disposición y dominio.

Es importante dejar alguna consideración respecto al ámbito de dominio. En derecho, expresiones como esta, además de la significación natural que tiene, el concepto es muy debatido por la trascendencia penal. Perdomo Torres, analizando precisamente el dominio sobre la causa del resultado como fundamento de la responsabilidad del garante, y teniendo como referente a SCHÜNEMANN, advierte cómo para este autor el resultado, “(...) sólo puede ser imputado al omitente, cuando él domine de manera actual la causa esencial de dicho resultado o el desvalimiento de la víctima (...)" (SCHÜNEMANn citado en PERDOMO TORRES, 2001, p. 64).

Igual que para SCHÜNEMANN, desconoce los deberes de salvamento (por la relación potencial del omitente con el resultado), pero reconoce el dominio sobre un ámbito objetivo de peligro (pp. 63 y ss.). Como lo afirma PERDOMO, este término corresponde a los deberes de seguridad en el tráfico. El autor resalta un segundo escenario de responsabilidad sobre el resultado: el que generan las relaciones de autoridad entre personas, o como lo denomina SchünemanN, el poder jurídico del poseedor del resultado, esto de trascendental importancia porque lo relaciona directamente con el sometimiento del soldado al mando, y en este recuadro la importancia que tienen los actos administrativos (ejemplo: una orden de operaciones). Se extienden estos conceptos, por cuanto el potencial omitente puede ser el 
poseedor de la autoridad legalmente constituida (el comandante) o el subordinado que se sujeta al acto administrativo. Estando inmersa la posibilidad de tener el dominio del hecho, se sugiere así que puede ser poseedor de la autoridad pero puede estar retirado en ese momento de su jurisdicción y con limitaciones por desinformación o falta material de esta sobre las condiciones del peligro de bienes jurídicos (se desconoce la capacidad del enemigo o se valora mal). En esta línea, tratando de imitar el análisis de JAVIER SÁNCHEZVERA (1997), es fundamental que se analice la problemática del dominio del hecho del omitente cuando hay un tercero que es el que domina verdaderamente el hecho, y el otro considerado omitente sólo tiene un dominio potencial del hecho, puede ser, entre otros, por la distancia a que se encuentra de la situación que exige el deber de actuar, sea porque está distante de la persona amenazada por el peligro (la población civil amenazada o la misma tropa en combate), porque está cerca o distante del sujeto que coloca en peligro el bien jurídico (los grupos al margen de la ley, la tropa que está en combate o los dos al tiempo) o cerca de la cosa que genera el peligro del bien jurídico (un artefacto explosivo.)

No tratar de exponer de manera general un ejemplo sobre la omisión impropia, sería un desatino, por lo tanto se expone el siguiente muy cercano a hechos ocurridos en la realidad del conflicto colombiano: En la jurisdicción de una División del Ejército se vive una situación tensa en virtud de los comicios electorales, y la variedad de amenazas cobijan toma de poblaciones, retenes guerrilleros, asalto a bases militares, emboscadas a patrullas, acciones terroristas con explosivos, alteración del sistema de alumbrado público, voladura de puentes, entre otros, por lo que en la rutina de las autoridades civiles y los mandos militares disponen la ejecución de un consejo de seguridad, el cual se lleva a cabo, y entre la asignación de jurisdicciones y misiones disponen la coordinación entre las tropas para no causar enfrentamientos entre las mismas.

A pesar de estos mandatos de lógica coordinación, una patrulla de agentes de la policía penetra a la jurisdicción donde se encontraba una tropa militar, se presenta el enfrentamiento por falta de coordinación, y como consecuencia pierden la vida varios agentes. Si bien el resultado se atribuye a una acción, se considera la posibilidad de una 
omisión de parte, ya sea del comandante militar o del comandante policial. En este contexto, y para reflejar la difícil dinámica del conflicto y sus consecuencias en general, se puede observar que no se cumplió ninguna de las múltiples amenazas del enemigo, lo que surgió fue una fatal descoordinación, con el agravante de que fue advertida en el Consejo de Seguridad ejecutado días antes.

Entre los varios interrogantes que pueden surgir se resaltan los siguientes:

a) ¿Los comandantes en los distintos niveles de mando y en los diferentes actos administrativos dejaron constancia de la deficiencia en las capacidades materiales para atender la diversidad de amenazas?

b) De las amenazas existentes, ¿cuáles se dejaron inmersas en la expresión del Código Penal de que la realización de la infracción penal fue prevista como probable y su no producción se dejó librada al azar? ¿Fue debidamente registrada en Actos Administrativos?

c) ¿Tenían los comandantes de alto nivel algún deber jurídico y estaban en capacidad de evitar el resultado?

d) ¿Cuál es el valor probatorio del acta del Concejo de Seguridad?

e) ¿Todas las tropas, militares y policiales, que sostuvieron el encuentro obedecían órdenes de autoridad competente y con los rigorismos legales?

f) Si existieron órdenes verbales, ¿cómo acreditarlas en un proceso?

g) ¿Qué pasa con los posibles garantes de grado inferior, si ellos no tuvieron la comunicación oportuna sobre los movimientos de cada uno de los componentes armados?

h) ¿Quienes tenían a cargo la protección real de bienes jurídicos y quienes eran sus beneficiarios?

i) ¿Cuál es el límite del ámbito de dominio de cada uno de los Comandantes?

Para concluir este capítulo se quieren establecer algunos de los elementos estructurales que dispone el artículo 25 del Código Penal, el primer elemento está conformado por el deber 
jurídico de actuar, el segundo corresponde al poder evitar el resultado que esta ceñido a las competencias funcionales, materiales y territoriales para el caso concreto, el tercero, corresponde a la figura de la posición de garante como eje central, figura en la cual están insertas las capacidades; el cuarto elemento correspondería a los eventos consignados por la Corte Constitucional (Sentencia SU 1184/2001) en los cuales los miembros de la Fuerza Pública pueden ser garantes, a saber: la creación de riesgos para bienes jurídicos y el surgimiento de deberes por la vinculación a una institución estatal, y el quinto corresponde también a lo regulado por la Corte en cuanto se debe estudiar la tipicidad, la antijuricidad y la culpabilidad de la conducta. En este marco y por las especiales circunstancias en que se desarrolla el conflicto interno, saltan a la vista las amplias responsabilidades del garante sobre la normatividad internacional como el Estatuto de Roma, el respeto de los derechos Humanos y el Derecho Internacional Humanitario, de donde emergen figuras trascendentales como el concepto de objetivo militar, las personas y los bienes protegidos como parte del principio de distinción, los mismos principio de necesidad, de proporcionalidad, de dignidad humana y no menos trascendental como se verá adelante, es la armonía que debe haber entre la Constitución, el bloque de constitucionalidad, la ley penal y los reglamentos, manuales y protocolos militares, todo lo anterior con significativa influencia sobre los distintos ángulos que tienen que ver con la posición de garante.

La tabla No 13 anexa, trata de esquematizar la problemática del delito de omisión propia y su componente principal como lo es la posición de garante. Seguidamente se agregan las tablas 14,15 y 16 , que resumen las conductas punibles que atentan contra la vida y la integridad personal, la libertad individual y la libertad y formación sexual, como lo dispone el parágrafo del artículo 25 de la ley 599 de 2.000.

\subsubsection{La posición de garante}

El significado de la posición de garante, examinado a la luz del diccionario, relaciona el término inmediatamente con "garantía", la que a su vez significa: "Responsabilidad asumida por un contratante, cosa que asegura y protege contra algún riesgo o necesidad. 
Derechos que garantiza la Constitución a los miembros de un Estado" (Círculo de Lectores, 1992).

La Corte Suprema de Justicia (Proceso 25536 de 2006) concreta la posición de garante, así:

"Posición de garante es la situación en que se halla una persona, en virtud de la cual tiene el deber jurídico concreto de obrar para impedir que se produzca un resultado típico que es evitable. Cuando quien tiene esa obligación la incumple, y con ello hace surgir un evento lesivo que podía ser impedido, abandona la posición de garante."

Más adelante resalta el Tribunal Penal un sentido restringido para la figura de garante, y otro amplio. El primero, que se refiere a las violaciones de los mandatos que están tipificados en la ley, que serían los casos de la omisión propia e impropia, y el sentido amplio que dice:

“(...) es la situación general en que se encuentra una persona que tiene el deber de conducirse de determinada manera, de acuerdo con el rol que desempeña dentro de la sociedad. Desde este punto de vista, es indiferente que obre por acción o por omisión, pues lo nuclear es que vulnera la posición de garante quien se comporta en contra de aquello que se espera de ella, porque defrauda las expectativas."

De otro lado, FORERo RAMírez lo define así: "Como garante definiremos a aquel sujeto que tiene el deber jurídico (no moral) de vigilar y garantizar la indemnidad de uno o varios bienes jurídicos pertenecientes a determinadas personas y que se hallan previamente individualizadas" (2002, p. 55).

La Sentencia SU-1184 de 2001, que decidió una colisión de competencias en el caso de Mapiripan $^{77}$, incluyó un detallado análisis de la posición de garante en general, y de la

\footnotetext{
${ }^{77}$ Los hechos del caso Mapiripan fueron relatados por el Tribunal Constitucional, así: "Hechos: Durante los días 15 a 20 de julio de 1997, un grupo de personas que vestían prendas privativas de las Fuerzas Militares irrumpió en el municipio de Mapiripan, Meta. Arribaron al sitio, procedentes de San José de Guaviare, lugar al cual habían llegado por vía aérea días antes. Durante su estancia en dicho municipio sometieron violentamente a la población de Mapiripan, impidieron el ejercicio de los derechos de locomoción y comunicación, cerraron varias oficinas públicas, interrumpieron el desenvolvimiento de las actividades
} 
posición de garante y la fuerza pública en particular. En general, aunque el Alto Tribunal reconoció en su momento que éste no se había manifestado de manera expresa en cuanto al tema de las conductas omisivas, hace en la sentencia un breve pero claro recorrido sobre la omisión y la posición de garante ${ }^{78}$. Es relevante resumir para este estudio, cómo en la libertad de configuración de la sociedad (la competencia por organización), para su normal desarrollo, se permite la ejecución de múltiples actividades como el transporte terrestre, aéreo y marítimo, las megaconstrucciones y otras muchas, en las cuales el individuo crea riesgos para bienes jurídicos propios y de otras personas, y cómo de la creación de estos riesgos (no por el principio de solidaridad) surgen los deberes de seguridad en el tráfico, y

normales de ese municipio y procedieron a retener, torturar y asesinar un total de 49 personas, cuyos cadáveres descuartizados en su gran mayoría fueron arrojados al Río Guaviare. Se atribuye a dos miembros de la fuerza pública que tenían competencia material, funcional y territorial sobre la zona (posición de garante), que frente a la agresión armada contra la población civil (situación de peligro generante del deber) no prestaron ningún tipo de ayuda (no realización de la acción esperada) cuando contaban con medios materiales para hacerlo (capacidad individual para realizar la acción). Durante los hechos, fueron informados sobre la forma como se desarrollaban en el municipio las graves violaciones a los Derechos Humanos (dolo o imprudencia)".

78 “(...) La dogmática naturalista del siglo XVIII en materia penal trató de edificar el Delito de Omisión sobre la base de los elementos característicos del delito de comisión. Con fundamento en el derecho liberal que surge después de la Revolución Francesa, FEUERBACH encontró que la «obligación originaria» de todo ciudadano estaba constituida por prohibiciones: no realizar conductas que pudieran ocasionar daño a terceros. Los mandatos, es decir la obligación de realizar determinados comportamientos orientados a proteger bienes jurídicos, tenían una naturaleza excepcional, porque en principio no se tiene el deber de iniciar acciones de salvamento a favor de otra persona. Para que ello ocurra se requiere un «deber jurídico especial» que obligue a la evitación de determinados resultados. Los juristas del siglo XIX lo encontraron inicialmente en la ley y el contrato. Posteriormente le agregaron la injerencia (el comportamiento peligroso anterior) y las estrechas comunidades de vida. Este enfoque se caracterizó por el estudio de las fuentes formales, es decir, por determinar dónde nacen los deberes jurídicos de evitación del resultado, más no por precisar su fundamento. El énfasis hacia el estudio material de las posiciones de garante es una tarea del siglo XX, que tuvo su máximo exponente en la llamada teoría de las funciones: es la posición que ocupe el sujeto en la sociedad, independientemente del reconocimiento expreso del deber de actuar en una ley, lo que fundamenta la obligación de evitar determinados resultados. Si bien el concepto de garante, como criterio básico de equivalencia entre la acción y la omisión se debe a NAGLER (1938), el principal representante de un criterio material fue ARMIN KAUFMANN. Para él la posición del sujeto con respecto al control de fuentes de peligro (garantes de vigilancia) o frente a bienes jurídicos que debe defender ante ciertos peligros que los amenace (garantes de protección) determina la posición de garante. El moderno derecho penal de orientación normativista se caracteriza por el abandono de los criterios con base en los cuales la dogmática naturalista del siglo XIX, predominante hasta la década de 1980 en el siglo XX, edificó la teoría del delito: causalidad, evitabilidad y dolo. Actualmente, el juicio de imputación se fundamenta en la delimitación de ámbitos de competencia: sólo se responde por las conductas o resultados que debo desarrollar o evitar en virtud de los deberes que surgen de mi ámbito de responsabilidad y que se desprenden de los alcances de la posición de garante. Lo demás, salvo los deberes generales de solidaridad que sirven de sustento a la omisión de socorro, no le concierne al sujeto, no es de su incumbencia (...)". 
de la mano, los deberes de salvamento, los dos originados en competencias por organización. En la sentencia mencionada se presenta el siguiente ejemplo:

"(...) si alguien abre una zanja frente a su casa, tiene el deber de colocar artefactos que impidan que un transeúnte caiga en ella. Ahora bien, si las medidas de seguridad fracasan y el riesgo se exterioriza amenazando con daños a terceros o el daño se produce, un peatón cae en la zanja, surgen los llamados deberes de salvamento, en los cuales el sujeto que ha creado con su comportamiento peligroso anterior (generalmente antijurídico) un riesgo para los bienes jurídicos, debe revocar el riesgo, prestarle ayuda al peatón y trasladarlo a un hospital si es necesario (pensamiento de la injerencia). O el ejemplo de seguridad en el tráfico, “(...) que también pueden surgir por asunción de una función de seguridad o de salvamento, como en el caso del salvavidas que se compromete a prestar ayuda a los bañistas en caso de peligro".

Distingue la providencia aquellos deberes que se tienen por pertenecer el individuo a lo que se llama:
"Instituciones básicas para la estructura social (competencia institucional) y que le son impuestas al ciudadano por su vinculación a ellas. Por ejemplo, las relaciones entre padres e hijos y ciertas relaciones del Estado frente a los ciudadanos. Estos deberes se caracterizan porque el garante institucional tiene la obligación de configurar un mundo en común con alguien, de prestarle ayuda y protegerlo contra los peligros que lo amenacen, sin importar que el riesgo surja de un tercero o de hechos de la naturaleza. Por ejemplo, el padre debe evitar que un tercero abuse sexualmente de su hijo menor, y si no lo hace, se le imputa el abuso".

En lo particular, y aterrizando la problemática de la posición de garante hacia la Fuerza Pública, el Honorable Magistrado Montealegre, en la misma sentencia 1184, deja expreso que: "Un miembro de la fuerza pública puede ser garante cuando se presenten cualquiera de los dos fundamentos de la responsabilidad explicados: creación de riesgos para bienes jurídicos o surgimiento de deberes por la vinculación a una institución estatal".

La Sentencia SU-1184 de 2001, los explica así:

“a) Los peligros para los bienes jurídicos pueden surgir no sólo por la tenencia de objetos (una lámpara de gas, una teja deteriorada), armas (una pistola, una dinamita), animales (un perro desafiante), sino también de personas que se 
encuentran bajo nuestra inmediata subordinación. En efecto, en las relaciones de jerarquía, el superior con autoridad o mando, tiene el deber de tomar medidas especiales (deberes de seguridad en el tráfico) para evitar que personas que se encuentran bajo su efectivo control, realicen conductas que vulneren los derechos fundamentales. Vg. Si el superior no evita - pudiendo hacerlo- que un soldado que se encuentra bajo su inmediata dependencia cometa una tortura, o una ejecución extrajudicial, o en general un delito de lesa humanidad, por ser garante se le imputa el resultado lesivo del inferior y no el simple incumplimiento a un deber funcional.

El derecho penal internacional consuetudinario, desde el famoso caso Yamashita, en el cual se condenó en 1945 a un general del ejército Japonés por “(...) omitir ilícitamente y faltar a su deber como comandante de controlar las operaciones de los miembros bajo su mando, permitiéndoles cometer atrocidades brutales y otros crímenes graves contra la población de Estados Unidos, de sus aliados y dependencias, particularmente las Filipinas (...)", ha venido reconociendo que el miembro de la fuerza pública que ostenta autoridad o mando debe adoptar medidas especiales para evitar que las personas que se encuentren bajo su efectivo control o subordinación, realicen conductas violatorias de los Derechos Humanos. Jurisprudencia que se ha reiterado en los diversos Tribunales Penales Internacionales, desde Núremberg hasta los ad-hoc para la ex Yugoslavia y Ruanda. Doctrina que se plasmó normativamente en el art. 28 del Estatuto de Roma.

b) El Estado puede ser garante (competencia institucional) cuando se trata de ciertos deberes irrenunciables en un Estado social y democrático de derecho. Por ejemplo, es irrenunciable la protección de la vida e integridad de todos los habitantes del territorio y la defensa de la seguridad interior y exterior de la nación. Como el Estado no puede responder directamente en el campo penal, el juicio recae en el titular de la función correspondiente. Por ende, para que el miembro de la fuerza pública sea garante, se requiere que en concreto recaiga dentro de su ámbito de competencia (material, funcional y territorial) el deber específico de proteger los derechos constitucionales de los ciudadanos de la República. En consecuencia, si un miembro de la fuerza pública que tiene dentro de su ámbito de responsabilidad el deber de resguardar un sector de la población amenazada por grupos al margen de la ley, no inicia la acción de salvación cuando ostenta los medios materiales para hacerlo, se le imputan los resultados lesivos (las graves violaciones a los Derechos Humanos) que estos cometan en contra de los habitantes."

En este sentido, dice la misma jurisprudencia que para imputar una conducta o un resultado es fundamental concretar sobre quién recae la posición de garantía que tendría en este caso 
el militar, y a la vez definir si esa posición de garante proviene de la creación de riesgos o de los roles institucionales, es decir de los deberes que surgen por pertenecer a instituciones básicas de la sociedad. Con esta base, para hacer el juicio de imputación es necesario considerar cuatro aspectos fundamentales, a saber: el riesgo permitido, el principio de confianza, las acciones a propio riesgo y la prohibición de regreso. Finalmente, y luego de demostrada la creación del riesgo desaprobado, es necesario que este, es decir, que el mismo riesgo creado para el sujeto sea el que se concrete en la producción del resultado.

En este campo del juicio de imputación, especialmente en lo concerniente a las figuras a la creación de riesgos y a que este riesgo creado sea el que se concrete en la producción del resultado, resulta sustancial, señalar que PERDOMO (2001, pp. 41 y ss.) hace sus propias consideraciones respecto a diversos criterios para la asignación de la posición de garante. Refiriéndose a ANDROULAKIS, se estudia la cercanía social (no entendida como métrica o espacial sino como social) como elemento importante para determinar la equiparación entre el delito de comisión y el de comisión por omisión, haciendo con este argumento tres diferenciaciones que bien caben en el quehacer de las Instituciones Castrenses, pero desde la óptica del tiempo, el espacio, y claro, lo social: a) cerca de la persona amenazada por el peligro; b) cerca del autor de la lesión al bien jurídico, y c) cerca a la cosa que genera el peligro. PERDOMO las engloba con acierto en el concepto funcional de proteger a determinadas personas, como de vigilar o controlar fuentes de peligro.

Si bien la posición de garante como eje de la Omisión Impropia tiene su relación directa con la función militar, y dentro de esta especialmente para el caso, con la asunción $\operatorname{voluntaria}^{79}$, las tres diferenciaciones de ANDROULAKIS tienen notoriedad a la hora de asumir la cimentación de la posición de garante y realizar el juicio de valoración de la conducta omisiva, claro está que en determinadas circunstancias temporales y espaciales, es decir más allá del concepto de cercanía social que explica PERDOMO. La notoriedad

\footnotetext{
${ }^{79} \mathrm{Si}$ bien el punto de partida para edificar la posición de garante para los militares es la asunción voluntaria de protección de personas o fuentes de riesgo, no le son nada ajenas la estrecha comunidad de vida entre personas (la vida en cuarteles, pero particularmente las actividades riesgosas que se desarrollan dentro de estas, ejemplo, el cruce de un río), la realización de actividades riesgosas por varias personas (la ejecución de cursos de combate) y la creación de precedente de situaciones antijurídicas de riesgo próximo para el bien jurídico correspondiente (campos minados).
} 
proviene precisamente de la multiplicidad de eventos en los que las Fuerzas Militares están creando riesgos y en este marco se resaltan, de una parte, los resultados impredecibles de los riesgos que se asumen, y de otro lado, las presiones a que está sometido el militar para asumir unos riesgos y otros dejarlos al azar por falta de disponibilidad de recursos y credibilidad de las alertas, entre otros.

Las definiciones de la posición de garante, las consideraciones de PeRdomo (2001, pp. 41 y ss.) cuando hace sus propias consideraciones respecto a diversos criterios para la asignación de la posición de garante y se refiere ANDROULAKIS y la diversidad de creación de riesgos como parte de la amplia misión de la Institución Militar, son aspectos que en el marco de la posición de garante obligan a incluir el análisis de la doble responsabilidad que tienen los mandos, puede relacionar la frecuente permanencia de esta en el ámbito de la figura de garantía, de un lado, la orden y necesidad de actuar (el deber jurídico) incluyendo la posibilidad de incurrir en una omisión, y de otro lado, deben asumir el control de los subalternos para evitar que estos se enmarquen en comportamientos omisivos y/o para que estos actúen acorde a la misión y a las políticas de los Comandos Superiores referentes al respeto de los derechos fundamentales. Cita la jurisprudencia (Sentencia SU-1184 de 2001) el siguiente ejemplo: “(...) Si el superior no evita, pudiendo hacerlo, que un soldado que se encuentra bajo su inmediata dependencia cometa una tortura, o una ejecución extrajudicial, o en general un delito de lesa humanidad, por ser garante se le imputa el resultado lesivo del inferior y no el simple incumplimiento a un deber funcional".

Esta doble responsabilidad, particularmente la del control sobre los subalternos, también la contempla el Estatuto de Roma en el artículo 28 de la siguiente manera:

"Responsabilidad de los Jefes y otros superiores. Además de otras causales de responsabilidad penal de conformidad con el presente Estatuto por crímenes de competencia de la Corte: El jefe militar o el que actúe efectivamente como jefe militar será penalmente responsable por los crímenes de la competencia de la Corte que hubieren sido cometidos por fuerzas bajo su mando y control efectivo, o su autoridad y control efectivo, según sea el caso, en razón de no haber ejercido un control apropiado sobre esas fuerzas cuando: i) Hubiere sabido o, en razón de las 
circunstancias del momento, hubiere debido saber que las fuerzas estaban cometiendo esos crímenes o se proponían cometerlos; y ii) No hubiere adoptado todas las medidas necesarias y razonables a su alcance para prevenir o reprimir su comisión o para poner el asunto en conocimiento de las autoridades competentes a los efectos de su investigación y enjuiciamiento. En lo que respecta a las relaciones entre superior y subordinado distintas de las señaladas en el apartado a), el superior será plenamente responsable por los crímenes de la competencia de la Corte que hubieran sido cometidos por subordinados bajo su autoridad y control efectivo, en razón de no haber ejercido un control apropiado sobre sus subordinados, cuando: i) Hubiere tenido conocimiento o deliberadamente hubiere hecho caso omiso de información que indicase claramente que los subordinados estaban cometiendo esos crímenes o se proponían cometerlos; ii) Los crímenes guardaren relación con actividades bajo su responsabilidad y control efectivo; y iii) No hubiere adoptado todas las medidas necesarias y razonables a su alcance para prevenir o reprimir su comisión o para poner el asunto en conocimiento de las autoridades competentes a los efectos de su investigación y enjuiciamiento.”

Sin duda este tema es de agudo debate: se puede considerar, que es una norma bastante amplia y generadora de responsabilidad sin fin; también se puede ver desde una óptica restrictiva al punto que la consideren generosa para prevenir los desmanes de los servidores públicos. Todo depende indudablemente del caso concreto que se estudie, y allí brillarán razones objetivas y subjetivas para estudiar y decidir. El diseño de la norma internacional contiene exigencias que merecen especial atención y reflexión, por ejemplo: i.) el control apropiado de las fuerzas, ii.) cuando hubiere sabido o hubiere debido saber; las connotaciones se derivan del momento de la valoración del comportamiento omisivo, el cual por lo general se hace ex post y bajo múltiples presiones de orden político nacional e internacional, y de orden social y con una alta cuota de desconocimiento de la dinámica de las operaciones, el cuestionamiento de estos vértices componentes de la norma tiene sus complicaciones, en el caso del control apropiado sobre las fuerzas tiene especial relevancia las extensas responsabilidades territoriales y la deficiencia de medios materiales de control (Ej: la carencia de helicópteros de comando), y relacionado con la expresión "hubiere debido saber", es necesaria la presencia de la lealtad del subalterno (como parte del ya referido honor militar) o del principio de confianza hacia su superior (como elemento de la imputación objetiva), para que el comandante conozca la verdadera situación de los acontecimientos en la zona de operaciones. Al respecto se puede confrontar, entre otros, el 
caso San José de Apartadó $^{80}$ y el Proceso 25682 de 2009, referenciado por APONTE CARdona (2011, p. 221), el que manifiesta que "Existen eventos de comportamientos realizados por servidores oficiales, los que en principio aparecen a la luz pública efectuados bajo el aparente mando de la legalidad o como resultado de presuntas acciones legítimas de defensa de la patria, la democracia y las Instituciones" ${ }^{\prime 81}$, voz que es reiterada en el Proceso 29221 de 2009, afirmación que viene siendo desarrollada jurisprudencialmente (cfr. Sentencia SU-1184 de 2001) y que requiere conocimiento y acciones preventivas de orden institucional y legal. En contravía y en relación con la misma norma internacional, no merece discusión alguna, cuando el superior, ante los desmanes de los subalternos guarda silencio y no coloca los desmanes en conocimiento de las autoridades competente.

La amplitud de las responsabilidades de los miembros de las Fuerzas Militares, en condiciones de conflicto interno se extienden al conocimiento y aplicación de las normas sobre Derechos Humanos y Derecho Internacional, y si se quiere hacer más amplia la responsabilidad, esta inicia en el acomodamiento o como ya se anoto buscar la armonía de los manuales y reglamentos con el Derecho Penal, la Constitución y las normas internacionales que obligan a las Fuerzas Armadas en situaciones de conflicto, aspectos que se consideraran en el acápite siguiente.

\subsubsection{De la competencia funcional.}

En este acápite es significativo partir del precepto constitucional (Artículo 122) que expresa que: "No habrá empleo público que no tenga funciones detalladas en la ley o reglamento y para proveer los de carácter remunerado se requiere que estén contemplados en la respectiva planta y previstos sus emolumentos en el presupuesto correspondiente".

De otra parte, MARTÍNEZ LÓPEZ respecto de la competencia funcional, escribe:

\footnotetext{
${ }_{81}^{80}$ Juzgado Segundo Especializado de Antioquia, Sentencia Ordinaria N ${ }^{\circ} 41$, Medellín, agosto 04 de 2010.

${ }^{81}$ Corte Suprema de Justicia, Sala de Casación Penal, Proceso 29221 de 2009, M.P.: Yesid Ramírez Bastidas, posición reiterada en Corte Suprema de Justicia, Sala de Casación Penal, Proceso 25682 de 2009, M.P.: Yesid Ramírez Bastidas [cita de APONTE CARDONA (2011, p. 221)].
} 
"Acto propio de una función pública, es el que por ley o reglamento está adscrito a la competencia funcional de servidor público y éste tiene el deber legal de realizarlo. Puede tratarse de acto material, como capturar un delincuente; o acto intelectual, como proferir una sentencia; o acto material e intelectual como recepcionar un testimonio (MARTínEZ LÓPEZ, 2002, p. 145).”

También el servidor público está debidamente identificado en el artículo 20 del Código Penal, y la función pública se manifiesta en beneficio de los intereses colectivos que la sociedad reclama, es decir la protección de sus bienes jurídicos o en otras palabras, y parodiando lo dicho por la Corte Constitucional que se le garantice al ciudadano el ejercicio de sus derechos y libertades.

La misión de las Fuerzas Militares, la desarrolla la Corte Constitucional, entre otras, en la sentencia SU 1184 de 2001, en esta jurisprudencia se vinculan otros mandatos constitucionales, como los artículos 217 (Misión de las Fuerzas Militares), 218 (Función de la Policía Nacional) y el artículo $2^{\circ}$ (Fines esenciales del Estado), de los cuales se deduce la amplitud de la misión castrense y se aterriza des la óptica del orden constitucional en el marco de los fines del Estado y muy particularmente en "Garantizar la efectividad de los principios , derechos y deberes consagrados en la Constitución.”, así como la protección a las personas "En su vida, honra, bienes, creencias y demás derechos y libertades."

Escribió la Corte Constitucional en la Sentencia SU-1184 de 2001:

“(...) De ello se desprende que tiene el deber constitucional de garantizar que la soberanía y el orden constitucional no se vean menoscabados. Elementos centrales del orden constitucional lo constituye el cumplimiento pleno de los principios, derechos y deberes consagrados en la Constitución (art. $2^{\circ}$ de la Carta) y la preservación del monopolio del uso de la fuerza y las armas en manos del Estado. En relación con los fines previstos en el artículo $2^{\circ}$, la función de garante de las Fuerzas Militares no se equipara a las funciones asignadas en el artículo 218 de la Carta a la Policía Nacional. Sin embargo de ello no se desprende que no tengan por función básica garantizar el pleno ejercicio de los derechos y libertades por parte de los asociados. Antes bien, supone garantizar condiciones de seguridad colectivos y de carácter estructural, definidos en los conceptos de soberanía, independencia, integridad territorial e integridad del orden constitucional, que 
permitan una convivencia armónica. Las condiciones de seguridad dentro de dicho marco de seguridad estructural son responsabilidad de las fuerzas armadas.

Podría objetarse que esta interpretación desconoce el tenor literal del artículo 218 de la Carta, pues en dicha disposición se establece de manera diáfana que es fin primordial de la Policía Nacional "el mantenimiento de las condiciones necesarias para el ejercicio de los derechos y libertades públicas, y para asegurar que los habitantes de Colombia convivan en paz". Empero esta objeción llevaría al absurdo, lo que resulta abiertamente inconstitucional, de que las Fuerzas Militares estarían eximidos de garantizar el ejercicio de los derechos y libertades y para asegurar que los habitantes de Colombia convivan en paz."

Con estas premisas, de deben apuntar varios aspectos: el primero es la responsabilidad funcional de los miembros de la Institución desde la óptica del derecho Penal, de los Derechos Humanos y del Derecho Internacional Humanitario, el segundo, es la coherencia y permanente actualización que debe haber entre esta normatividad y la doctrina militar para el cumplimiento de la misión.

En cuanto a la normatividad de los Derechos Humanos y del Derecho Internacional Humanitario, las funciones del garante son suficientemente amplias, los Convenios de Ginebra en general, el artículo tercero común a los Convenios de Ginebra ${ }^{82}$ y el Protocolo

\footnotetext{
${ }^{82}$ Artículo 3.- En caso de conflicto armado que no sea de índole internacional y que surja en el territorio de una de las Altas Partes Contratantes, cada una de las Partes en conflicto tendrá la obligación de aplicar, como mínimo las siguientes disposiciones:

1.) Las personas que no participen directamente en las hostilidades, incluidos los miembros de las fuerzas armadas que hayan depuesto las armas y las personas puestas fuera de combate por enfermedad, herida, detención o por cualquier otra causa, serán, en todas las circunstancias, tratadas con humanidad, sin distinción alguna de índole desfavorable basada en la raza, el color, la religión o la creencia, el sexo, el nacimiento o la fortuna, o cualquier otro criterio análogo. A este respecto, se prohíben en cualquier tiempo y lugar por lo que atañen a las personas arriba mencionadas:

a.) Los atentados contra la vida y la integridad corporal especialmente el homicidio en todas sus formas, las mutilaciones, los tratos crueles, la tortura y los suplicios;

b.) La toma de rehenes;

c.) Los atentados contra la dignidad personal, especialmente los tratos humillantes y degradantes;

d.) Las condenas dictadas y las ejecuciones sin previo juicio ante un tribunal legítimamente constituido, con garantías judiciales reconocidas como indispensables por los pueblos civilizados.

2.) Los heridos y enfermos serán recogidos y asistidos.

Un organismo humanitario imparcial, tal como el Comité Internacional de la Cruz Roja, podrá ofrecer sus servicios a las partes en conflicto.

Además, las Partes en conflicto harán lo posible por poner en vigor, mediante acuerdos especiales, la totalidad o parte de las otras disposiciones del presente Convenio.
} 
II de los mismos ${ }^{83}$; las incidencias de la selección del objetivo militar ${ }^{84}$ acorde con su naturaleza, ubicación, finalidad o utilización, y el cumplimiento de los principios básicos del Derecho Internacional Humanitario, de necesidad militar ${ }^{85}$, distinción ${ }^{86}$, proporcionalidad $^{87}$ y el principio de trato humanitario. ${ }^{88}$

Una de las responsabilidades del garante en este campo tan importante, gira en torno a la selección del objetivo militar, en este sentido debe haber una relación directa entre el mandato constitucional, las apreciaciones de situación y la orden de operaciones, lo que viene a definir si el objetivo militar y en consecuencia la operación militar se enmarca como una operación relacionada con los Derechos Humanos, o si corresponde a una operación en el contexto del Derecho Internacional Humanitario ${ }^{89}$; en las dos vías, de manera general la operación debe contemplar el respeto a la dignidad humana, pero en el segundo escenario de las operaciones que tratan de controlar el conflicto interno se mezclan importantes prevenciones y figuras propias de ese tipo de confrontaciones como el respeto

La aplicación de las anteriores disposiciones no surtirá efecto sobre el estatuto jurídico de las partes en conflicto.

${ }^{83}$ Relativo a la protección de las víctimas de los conflictos armados sin carácter internacional.

${ }^{84}$ Sólo pueden ser considerados como objetivos militares aquellos bienes y personas que, por su naturaleza, ubicación, finalidad o utilización contribuyan eficazmente a la acción militar y cuya destrucción total o parcial captura o neutralización ofrezcan, en las circunstancias del caso, una clara ventaja militar. (D. Operacional, Pág. 56.)

${ }^{85}$ Principio de necesidad militar: "Derecho a emplear la violencia en la forma y el grado necesarios para obligar al adversario a someterse cuanto antes con el menor costo posible en dinero y vidas humanas." (Hernández, 2012, pág.252.)

${ }^{86}$ Principio de distinción: «a fin de garantizar el respeto y la protección a la población civil, las partes en conflicto harán distinción en todo momento entre población civil y combatientes, y entre bienes de carácter civil y objetivos militares y en consecuencia, dirigirán sus operaciones únicamente contra objetivos militares.»(Hernández, 2012, pág.252; art. 48, protocolo I.)

${ }^{87}$ Principio de proporcionalidad: "Una acción militar es proporcionada cuando no causa víctimas ni daños civiles excesivos en relación con el resultado global esperado en términos de ventaja militar. se debe suspender o cancelar un ataque hasta cuando se puedan tomar medidas específicas para evitar o minimizar víctimas civiles, si se advierte que tal ataque puede provocar daño excesivos.

está "prohibido lanzar un ataque cuando sea de prever que cause incidentalmente muertos y heridos entre la población civil, daños a bienes de carácter civil o ambas cosas, que sean excesivos en relación con la ventaja militar concreta y directa prevista". . (D. Operacional, Pág. 37.)

${ }^{88}$ Principio de trato humanitario y respeto por las garantías fundamentales de la persona: "Las personas civiles y las personas fuera de combate deberán ser tratadas con humanidad. Debe garantizarse el libre y pleno ejercicio de sus derechos fundamentales.” (Hernández, 2012, pág. 430.)

${ }^{89}$ La Corte Constitucional en la sentencia C-574 de 1992, cuando hizo la revisión oficiosa del Protocolo Adicional a los Convenios de Ginebra del 12 de Agosto de 1949 relativo a la protección de las víctimas de los conflictos armados internacionales (Protocolo I), hizo expresa manifestación a la aplicabilidad del Derecho Internacional Humanitario en situaciones de conflicto, por ser superiores las exigencias para ese caso concreto. 
y protección de enfermos, heridos, de no combatientes y por su puesto la protección de la población civil y de sus bienes, entre otros, todo como parte de las regulaciones y limitaciones que imponen los principios de necesidad, proporcionalidad y distinción.

Respecto al segundo punto, sobre la coherencia y permanente actualización que debe haber entre la normatividad penal y penal internacional y la doctrina militar para el cumplimiento de la misión, es interesante colocar sobre el papel, la materialización de la falta de dirección efectiva y control sobre algunos aspectos de la defensa y seguridad y en particular con el tema del conflicto interno y el desorden público que causan los distintos agentes generadores de violencia. Se puede observar que sobre el eje de la misión y las funciones que se cumplen, el garante para el cumplimiento de sus funciones, se ve avocado a diferentes criterios a la hora de ejercitarla en la academia, en la práctica y en el derecho penal; hay extremos que colocan al militar en una encrucijada o en el "dilema del soldado" $"$ : De una parte, se apunta a que el militar solo debe actuar en defensa de la soberanía, la independencia, la integridad del territorio nacional, y del orden constitucional, pero no se conoce el desarrollo de cada una de estos elementos estructurales, y de otra parte, esta quienes apuntan que las Fuerzas Militares, sobre la base del desarrollo jurisprudencial antes expuesto (SU 1184 de 2001), deben cumplir la función básica de garantizar el pleno ejercicio de los derechos y libertades por parte de los asociados, significaría que en procura de la protección de bienes jurídicos, la Fuerza Militar debe combatir la delincuencia organizada, la delincuencia común, drogadictos, jaladores de carros, practicantes del abigeato, asaltantes de buses intermunicipales, piratas terrestres, traficantes con armas y municiones, secuestradores y cualquier combinación de estas con los actos que puedan cometer las llamadas bandas criminales. Pero entre esos extremos existen las disposiciones del manual de derecho operacional y aquellas directivas trazadas por el Ministerio de Defensa ${ }^{91}$, las cuales extrañamente tratan de modificar la Constitución, desde la trinchera del escritorio del mismo Ministerio de Defensa, donde civiles y militares incluidos, ignoran la realidad que vive el soldado colombiano, entonces sus directrices

\footnotetext{
${ }^{90}$ La frase es del Manual de Derecho Operacional, Página 94.

${ }^{91}$ Directiva 208 de 2008 y 216 de 2009.
} 
llegan hasta los altos tribunales donde los errores de manuales y directivas, se materializan en gravísimas condenas contra los integrantes de la Institución militar que son víctimas del dilema doctrinal, disciplinario y penal que se le impone al soldado, hasta el punto que hoy tal vez, este le tema más a las consecuencias de un proceso penal que a las mismas consecuencias que le pueda acarrear un combate con el enemigo; se cita como ejemplo aparte de una sentencia para analizar y reflexionar $^{92}$ de la cual no se encontraron las normas militares y penales que impiden disparar en una operación de registro y tampoco las normas que disponen lanzar la proclama de presencia de la tropa, es decir lo que cubriría los elementos normativos del tipo que se especularon allí; tema importante, si se tiene en cuenta que el manual de Operaciones y Maniobras de Combate, no contiene la acción precisa de disparar, como no la tiene ningún tipo de operación, método, técnica o maniobra del mencionado Manual; es que, para claridad de los operadores de justicia, el Manual no puede contener ese preciso tipo de acción y no la puede tener por las mismas condiciones impredecibles de la guerra.

Con estos precedentes, es urgente la revisión de los actos administrativos que tienen que ver con las operaciones militares, para hacer que se enlacen con la normatividad del derecho internacional relacionada con el desorden público colombiano, se expone a manera de ejemplo:

Dice el citado Manual (FF.MM. 3-41, Pág. 95.) que desde el punto de vista legal existen dos tipos de operaciones militares:

\footnotetext{
${ }^{92}$ Como información y prevención para lo que los garantes ordene u omitan, no se trata de controvertir la sentencia, pero sí de que se conozca este tipo de manifestaciones. Escribió la Corte Suprema: "Ello es así. De las pruebas se constató, como bien lo expuso el a-quo, que la misión que les fue encomendada ese día por parte de los comandantes de operaciones y de pelotón fue de registro y control, no de combate. Así mismo, que dispararon sin haber hecho la proclama previa de alto, requerida en esos eventos. Es más, llegaron a tal conclusión aun a pesar de escuchar lo expuesto por los soldados en la audiencia del juicio oral y de reparar en las contradicciones de sus dichos. El censor se equivoca en sus apreciaciones porque la presencia legítima de los militares en el lugar de los acontecimientos no conlleva necesariamente a afirmar que el homicidio haya sido perpetrado en ejercicio de sus funciones o con ocasión de ellas y que, por tanto, tenga que operar el fuero militar. (Subrayado fuera de texto.) (Proceso N. ${ }^{\circ} 35099$ de 2011.).
} 
“(i) Operaciones en escenarios de hostilidades. Operaciones dirigidas contra un objetivo militar debidamente identificado relacionado necesariamente con un grupo armado organizado ${ }^{93} ; \mathrm{y}$

(ii) Operaciones para el mantenimiento de la seguridad. Todas las demás operaciones que no están dirigidas contra un objetivo militar específico."

En el contexto de estas operaciones se puntualizan entre otros, los siguientes aspectos importantes:

Las Operaciones en escenarios de hostilidades están dirigidas contra un objetivo militar debidamente identificado relacionado necesariamente con un grupo armado organizado; para este tipo de operaciones se emplea una tarjeta roja. Las Operaciones para el mantenimiento de la seguridad son las que no están dirigidas contra un objetivo militar específico; para este tipo de operaciones se planea la tarjeta azul. Se dispone que las Fuerzas Militares solo pueden actuar contra los grupos armados organizados como las FARC o como el E.L.N. y solo podrán actuar contra las llamadas BACRIM con la autorización del llamado grupo asesor, ${ }^{94} \mathrm{y}$ en el caso de ser autorizados para actuar contra

\footnotetext{
${ }^{93}$ El Comité Internacional de la Cruz Roja ha definido "grupo armado organizado", así:

"Grupos armados organizados que pertenecen a una parte no estatal a un conflicto armado incluyen tanto fuerzas armadas disidentes como otros grupos armados organizados. Fuerzas armadas disidentes son en esencia parte de las fuerzas armadas estatales, que se han vuelto en contra del gobierno. Otros grupos armados organizados reclutan sus miembros principalmente de la población civil, pero desarrollan un grado suficiente de organización militar para conducir hostilidades en favor de una parte al conflicto, aunque no siempre con los mismos medios, intensidad y grado de sofisticación que las fuerzas estatales.

En ambos casos, es crítico para la protección de la población civil distinguir una parte no estatal a un conflicto (por ejemplo una insurgencia, una rebelión o un movimiento secesionista) de sus fuerzas armadas (es decir, un grupo armado organizado). Al igual que los Estados que son parte a un conflicto, las partes no estatales están constituidas tanto por las fuerzas combatientes y partes de la población civil que las apoya como sus alas políticas o humanitarias. Sin embargo, el término grupo armado organizado se refiere exclusivamente al ala armada o militar de una parte no estatal: sus fuerzas armadas en un sentido funcional. Esta distinción tienen consecuencias importantes para determinar la membresía en un grupo armado organizado, en contraste con otras formas de afiliación con, y apoyo a, una parte no estatal al conflicto.” [(CICR Guía para interpretar la noción de participación directa en las hostilidades según el derecho internacional humanitario, 2009, Pág. 33-34.) En el Manual de Derecho Operacional, Pág. 94 y 95.]

${ }^{94}$ El grupo asesor está integrado al más alto nivel del mando político, militar y policial. EL grupo asesor lo integran los comandantes del Ejército de la Armada y la Fuerza Aérea, el Viceministro para la Política y asuntos internacionales y el Director de Derechos Humanos del Ministerio de Defensa nacional, los jefes de inteligencia y operaciones del Ejercito, la Armada y la Fuerza Aérea y los Comandantes y miembros de los estados mayores de las unidades, según el caso. También son miembros el Director General de la Policía Nacional, el Director de Inteligencia y el Director de Seguridad de la misma institución; también los son el director del CTI y el director Nacional de Fiscalías en representación del Fiscal General de la Nación o su
} 
este tipo de bandas tienen la obligación de hacerlo utilizando la tarjeta azul, es decir dentro del concepto de las llamadas operaciones para el mantenimiento de la seguridad. En este contexto se asignan unas funciones a los militares a las cuales se les coloca de un lado unas misiones y de otro, unas limitaciones, por lo menos así se evidencia de la revisión rápida entre el Manual de Derecho Operacional, el Reglamento de Operaciones y Maniobras de Combate Irregular y el Texto especial de Patrullaje, si bien por lo menos los dos primeros, como debe ser, referencian importante normatividad del Derecho Internacional Humanitario, el tercero no la tiene y no se ajusta a los lineamientos exigidos.

Respecto a la compilación de normas, se ha escrito:

"Si bien no ha sido posible compilar normas que logren incluir la variedad de casos que se presentan en la guerra, lo no previsto, no queda "a la apreciación arbitraria de los jefes de los ejércitos", debe observarse los principios del derecho de gentes. En el mismo sentido, es importante tener en cuenta que: "Todos los tratados por los que se rige la conducción de las hostilidades, así como el derecho consuetudinario internacional que obliga a todos los Estados, se basan en dos principios fundamentales relacionados entre sí: el de necesidad militar y el de humanidad que, juntos, significan que solo están permitidas las acciones necesarias para derrotar el bando contrario, mientras que están prohibidas las que causan sufrimientos o pérdidas innecesarios". Como se observara en la compilación de tratados en esta obra, los ámbitos más importantes que se reglamentan con esta finalidad son la elección de los objetivos y el uso de las armas (Comité Internacional de la Cruz Roja, 1990, pp. 9-15).”

De igual manera, en la introducción del Manual sobre el Derecho de la Guerra para las Fuerzas Armadas es visible la amplitud de la problemática cuando se expresa lo siguiente:

"A causa de la creciente complejidad de los conflictos armados modernos, el derecho de la guerra es también cada vez más complicado y resulta difícil a los militares distinguir lo que para ellos es importante.

2. Responsabilidad del Estado. Los Estados que han aprobado tratados internacionales sobre el derecho de la guerra deben "respetarlos y hacerlos

delegado. Se deja abierta la posibilidad de que participen otros funcionarios según las necesidades y temas a tratar. 
respetar" en todas circunstancias. El derecho de la guerra no puede regular todos los supuestos de manera detallada. Por lo tanto, es indispensable que a nivel nacional se establezcan las precisiones que se consideren adecuadas, en función de la situación y de las necesidades particulares de cada Estado”.

Así pues, en cada Estado se debe abordar el derecho de la guerra moderna desde una perspectiva estratégica, la situación estratégica (geográfica, demográfica, económica, política, militar) del Estado es determinante en cuanto a establecer las clarificaciones y precisiones indispensables para lograr el respeto efectivo del derecho de la guerra (DE Mulinen, 1991, pp. xvii y xviii)."

Estas dificultades funcionales para los combatientes militares y particularmente para los que deben desarrollar su capacidad funcional como garantes, les permite colocar en pugna doctrinal y académica, a la Constitución Nacional, las normas de Derecho Internacional Humanitario, los códigos penales común y militar y los reglamentos y manuales militares acompañados de las directivas ministeriales y del Comando General de las Fuerzas Militares, de lo cual, si se quiere englobar el problema, el punto central es la exigencia de actualización para el logro del principio de humanidad como fin último de las normas, el cual impone que "las personas civiles y los combatientes quedan bajo la protección y el imperio de los principios del derecho de gentes derivados de los usos establecidos, de los principios de humanidad y de los dictados de la conciencia pública.’De contera, las herramientas jurídicas de la Institución se fortalecerán para la defensa de sus miembros.

En el mismo sentido, la practica en las operaciones le demanda al garante, explorar la diversidad de situaciones que se le pueden presentar en aquellas operaciones que tienen la oportunidad de ejercitarle el proceso para la toma de decisiones e igualmente especular y tratar de concretar las situaciones que surgen de los actos terroristas que ejecutan algunos grupos al margen de la ley; es frecuente que en algunas ocasiones no coincida el planeamiento con la ejecución de la operación, sucede cuando se presentan cambios sustanciales entre lo planeado y lo que se encuentra en la zona de operaciones, ${ }^{95}$ o que

\footnotetext{
${ }^{95}$ El Porroso es el lugar donde ocurrieron unos hechos el día 08 de febrero de 2005, donde la operación se planeo sobre unas informaciones y ya en la zona de combate, el oficial subalterno en cargado tomó la decisión de atacar al enemigo convencido del objetivo militar analizado, sin embargo todo fue un engaño del grupo al margen de la ley, y el militar y la tropa fue conducid rápidamente a una zona de aniquilamiento y
} 
desde el mismo planeamiento se considere emplear armas de mayor impacto ${ }^{96}$ en virtud de los bienes jurídicos que se están protegiendo. El otro aprieto para el militar deviene en la fase de ejecución, de allí brotan acciones acertadas o equivocadas que devienen de una situación de combate, el tiempo de pensar y de reflexionar es el mismo o menor al que se demora el enemigo en causar la muerte al miembro o miembros de la patrulla militar, a manera de ejemplo, en un momento de combate se puede estimar superior la capacidad del enemigo y se decide no realizar la acción esperada, o entrando en la acción el enemigo demuestra la superioridad en armas y en su posición sobre el terreno; la otra situación. Entre tantas deviene de las acciones terroristas, donde el Comandante debe procurar ajustar velozmente todas sus acciones militares con la normatividad legal.

También en este acápite de las capacidades funcionales es importante resaltar que en la estructura del Estado la configuración del Estamento Militar y sus funciones difieren por lo menos, en cuanto a las operaciones militares ostensiblemente de otras organizaciones, por ejemplo de la parte médica. Si nos referimos a las más exigentes intervenciones quirúrgicas, como el trasplante de corazón o la resección de un tumor maligno del sistema nervioso central (en el cerebro), por lo general el equipo médico tiene los elementos temporales y espaciales a su favor, pueden desarrollar una serie de actividades protocolarias como los exámenes técnicos previos, la facilidad de concretar el diagnóstico acertado, y pueden tener antes de la cirugía el conversatorio suficiente con el paciente para calmar su ansiedad y darle las explicaciones necesarias del tratamiento (LóPEZ DíAZ, 1998). Finalmente, y en simple lógica, su paciente permanece inmóvil en la cirugía, y los galenos realizan su trabajo con la única presión de acertar, (deber objetivo de cuidado) en la aplicación de los protocolos dispuestos para ese tipo de cirugías.

sufre la pérdida de su vida y la de 19 compañeros. La zona de aniquilamiento corresponde a una parte del terreno que ha sido previamente establecido por el enemigo para conducir allí a una patrulla militar y obligarla a combatir en total desventaja.

${ }^{96}$ Puede analizarse los recursos humanos y materiales empleados en la Operación Fénix ejecutada contra Luis Édgar Devia Silva, alias "Raúl Reyes" en marzo de 2008. Más recientemente la llamada Operación Sodoma, ejecutada contra Víctor Julio Suárez Rojas, alias "Mono Jojoy" realizada en septiembre de 2010. Los dos eran cabecillas de las autodenominadas FARC. 
No sucede lo mismo en el cumplimiento de las funciones militares, pues por lo general los bienes jurídicos a proteger (población indefensa) se hallan distantes de donde están los que deben cumplir con el deber jurídico (la tropa). Por lo general el desplazamiento de ésta al lugar donde está obligada a concurrir en defensa de los bienes jurídicos está amenazado por las emboscadas o por los explosivos, o por la misma ausencia de recursos materiales para efectuar el desplazamiento. Al arribo al sitio de los hechos se debe enfrentar al grupo al margen de la ley que ataca los bienes jurídicos con las armas, de donde se infierne que no se está cerca de la persona amenazada por el peligro (la población), ni cerca del autor de la lesión al bien jurídico (el grupo al margen de la ley), y tampoco cerca a la cosa que genera el peligro (además del subversivo, los explosivos, las armas, las minas), factores, que como ya se advirtió cobran relevancia en la cita del profesor PERDOMO (2001b) cuando se refirió a ANDROULAKIS, pero sugiriendo un sentido métrico o espacial.

En el ámbito de la competencia funcional es significativo reseñar, así sea de manera corta, lo referente a los conceptos de soberanía, independencia, integridad del territorio nacional y el orden constitucional, todos estos como dispositivos que en determinado momento forman parte de la competencia funcional, entendida ésta como un todo, es decir, al desarrollo en conjunto de la actividad operacional y los factores que ésta conlleva se analizan la obediencia debida, los límites de tiempo y de espacio.

\subsection{Condiciones estructurales de la misión de las Fuerzas Militares}

Se pretende dar a conocer brevemente, y agitar el conocimiento sobre la trascendencia de las condiciones estructurales de la misión que atañe a las Fuerzas Militares, que con seguridad permiten llenar vacios sobre la amplitud constitucional y legal de la misión castrense. El ascenso en la jerarquía de los miembros de la Institución de cualquiera de las Fuerzas Militares implica proporcionalmente la asunción voluntaria de múltiples obligaciones constitucionales y legales, que en las actuales condiciones jurídico-militares le exigen conocerlas y colocarlas en práctica sobre el personal que comanda. 
En ese marco del conocimiento, puede implantarse como norma básica el artículo 217 de la Carta, y encadenar aquellas que se señalaron en la primera parte de este trabajo, como los artículos $2^{\circ}, 6^{\circ}, 93,209,124$ y 216 de la carta, así como las principales conclusiones de las manifestaciones jurisprudenciales. El conocimiento de este instrumental jurídico se debe extender a los subalternos que están directamente comprometidos en el cumplimiento de las órdenes y que abrazan los conceptos de soberanía, independencia, integridad del territorio nacional y defensa de las instituciones, como condiciones estructurales de la misión de las Fuerzas Militares, han tenido momentos de relevancia donde se ha visto involucrada la Institución Militar en la toma de decisiones trascendentes.

Antes de hacer referencia a los eventos en que se han debatido tales conceptos, se quiere registrar que fue a partir de la Constitución de 1886 que Colombia se declaró como República Unitaria ${ }^{97}$, y como tal se ejercía la soberanía sobre todo el territorio, para entonces, el concepto general de soberanía estaba menos relativizado que en la actualidad. TUÑón DE LARA en su trabajo sobre la obra de ROUSSEAU, este se refiere al concepto inalienable de la soberanía, así: "Digo, pues, que no siendo la soberanía sino el ejercicio de la voluntad general, no puede enajenarse jamás, y el soberano, que no es sino un ser colectivo, no puede ser representado más que por sí mismo: el poder es susceptible de ser transmitido, más no la voluntad.” Enseguida respecto a la concepción de la indivisibilidad de la soberanía manifestó: "Por la misma razón que la soberanía no es enajenable, es indivisible; porque la voluntad es general o no lo es; es la del cuerpo del pueblo o solamente de una parte de él. En el primer caso, esa voluntad declarada es un acto de soberanía y hace ley; en el segundo no es sino una voluntad particular o un acto de magistratura: es, a lo más, un decreto" (1975, pp. 57 y58.).

\footnotetext{
${ }^{97}$ La Constitución Política de 1886 se refería a la soberanía del país, así: “Artículo $\mathbf{2}^{\circ}$. La soberanía reside esencial y exclusivamente en la nación, y de ella emanan los poderes públicos, que se ejercerán en los términos que esta Constitución establece", precisión que hace luego que en su artículo $1^{\circ}$ declare que: "la nación colombiana se reconstruye en forma de república unitaria". Son dos precisiones gravitantes en la Carta; se estaba pasando del sistema federativo donde los Estados tenían su soberanía, razón por la cual se hace la aclaración de República unitaria en la nueva Constitución, y por lo tanto deja claro, en el siguiente artículo, el nuevo concepto de soberanía.
} 
Quizá en el pasado la percepción del concepto de soberanía podría decirse que tenía muchos visos de absoluto, era más rígido y estricto, por las mismas connotaciones que tiene, sin embargo la misma dinámica política, económica, social y militar ha hecho que el concepto tenga cierta movilidad, causada especialmente por la necesidad de alianzas políticas regionales y mundiales, las diferentes formas de mercado entre naciones y el intercambio de tecnología a nivel mundial, así como las necesidades sociales, especialmente la de buscar la paz entre los pueblos y el auge por el respeto de los Derechos Humanos y del Derecho Internacional Humanitario, relativizan el concepto de soberanía. ${ }^{98}$

La Corte Constitucional, a raíz de la revisión oficiosa del Protocolo adicional a los Convenios de Ginebra del 12 de agosto de 1949, relativo a la protección de las víctimas de los conflictos armados internacionales (Protocolo I adicional), escribió en la Sentencia C574 de 1992:

"La idea de soberanía nacional no puede ser entendida hoy bajo los estrictos y precisos límites concebidos por la teoría constitucional clásica. La interconexión económica y cultural, el surgimiento de problemas nacionales cuya solución sólo es posible en el ámbito planetario y la consolidación de una axiología internacional, han puesto en evidencia la imposibilidad de hacer practicable la idea decimonónica de soberanía nacional. En su lugar, ha sido necesario adoptar una concepción más flexible y más adecuada a los tiempos que corren, que proteja el núcleo de libertad estatal propio de la autodeterminación, sin que ello implique un desconocimiento de reglas y de principios de aceptación universal. Sólo de esta manera puede lograrse el respeto de una moral internacional mínima que mejore la convivencia y el entendimiento y que garantice el futuro inexorablemente común e interdependiente de la humanidad. La paz mundial y la subsistencia planetaria están en juego.”

Un caso reciente de resonancia nacional, y en el que fue motivo de discusión el concepto de soberanía, se presentó cuando en el periodo de gobierno 1998-2002 la Ley 418 de 1997

\footnotetext{
${ }^{98}$ Dijo la Corte: "Se mantienen constantes tres elementos de la soberanía: (i) el entendimiento de la soberanía como independencia, en especial frente a Estados con pretensiones hegemónicas; (ii) la aceptación de que adquirir obligaciones internacionales no compromete la soberanía, así como el reconocimiento de que no se puede invocar la soberanía para retractarse de obligaciones válidamente adquiridas, y (iii) la reafirmación del principio de inmediación según el cual el ejercicio de la soberanía del Estado está sometido, sin intermediación del poder de otro Estado, al derecho internacional” (Sentencia C-601 de 2001).
} 
otorgó facultades al Presidente de la República para ubicar a las organizaciones armadas ilegales en zonas determinadas del territorio nacional. Al materializarse la norma se sitúo el grupo insurgente autodenominado Fuerzas Armadas Revolucionarias de Colombia (FARC), en la que en su momento se denominó “zona de distensión”. Entre las acciones jurídicas que hubo contra la Ley 418 se presentó una demanda por inconstitucionalidad contra el artículo $8^{\circ}$ (parcial) del citado precepto legal, y con tal motivo la Corte Constitucional se pronunció respecto al concepto de soberanía, reafirmando los planteamientos en dirección a cómo la noción de esta no es posible considerarla en un sentido absoluto, sino que, en la actualidad, distintos factores crean obligaciones a los Estados que la comprometen.

Manifestó la Corte en la Sentencia C-048 de 2001:

"Tal estado de cosas no ha determinado la disolución del concepto de soberanía, pero sí su reformulación en términos que compatibilizan la independencia nacional con la necesidad de convivir dentro de una comunidad supranacional. Las obligaciones internacionales, difíciles antes de conciliar con la existencia de un "poder autónomo, incondicionado y absoluto", resultan perfectamente compatibles con un "poder con suficiente autonomía para gobernar dentro de su territorio y obligarse frente a otros que hacen lo mismo dentro del suyo".

En este mismo sentido, y con el mismo motivo (la llamada "zona de distensión") el Tribunal Constitucional tuvo que pronunciarse en virtud a que se dispusieron unos mecanismos de verificación internacional de las zonas para el diálogo ${ }^{99}$. Luego de su análisis concluye la Corte, entre otros aspectos, que la idea de la soberanía absoluta es modificada por el derecho de las personas ${ }^{100}$, dicho de otra manera por el Derecho Humanitario. Es la primacía de la voluntad general, del respeto a sus derechos frente al poder político. Cuando se relativiza el concepto de soberanía ${ }^{101}$ se está ante un tema que

\footnotetext{
${ }^{99}$ Con relación a la constitucionalidad de este mecanismo, puede consultarse la Sentencia C-214 de 1993 , M.P.: José Gregorio Hernández Galindo.

${ }^{100}$ Dijo la Corte que “(...) esta concepción corresponde más a la idea de un Estado social de derecho fundado en la soberanía del pueblo y en la primacía de los derechos inalienables de la persona (C.P. arts. $1^{\circ}, 3^{\circ}, 5^{\circ}$ )" (Sentencia C-225 de 1995).

${ }^{101}$ En el diario El Tiempo, que circuló el 23 de enero de 2005, hay tres conceptos muy válidos respecto a la soberanía: MARTHA ARDILA de la Universidad Externado de Colombia dice: "el concepto de soberanía ya no
} 
influye directamente en la misión constitucional impuesta a las Fuerzas Militares, y con mayor razón si están presentes los Derechos Humanos y el Derecho Internacional Humanitario, que son precisamente los renglones que en el cuadro del conflicto interno tiene seria incidencia en las batallas jurídicas que tienen que enfrentar los miembros de la Institución Militar.

En este escenario hay otros ejemplos patrios que se tienen relación directa con la misión constitucional, como los episodios que tuvieron que ver con las capturas de Simón Trinidad y Rodrigo Granda ${ }^{102}$, incidentes menores si entráramos a considerar los hechos relacionados con el ataque al campamento del grupo al margen de la ley FARC que estaba ubicado en el vecino país de Ecuador ${ }^{103}$. En contrasentido, ¿si los militares no ejecutan estas acciones, podrían estar incursos en acciones omisivas? Seguramente, porque el mismo sistema democrático permite lanzar las denuncias que el ciudadano crea conveniente, ya sea como verdadero control social o por motivos perversos.

Entendido y aceptado el concepto de soberanía como relativo, en el mismo marco de la llamada "zona de distensión", se consideraba fracturada igualmente la integridad del territorio nacional, otro de los elementos esenciales de la misión constitucional, lo que motivó algunos pronunciamientos de los mandos militares del momento, pues la zona fue despejada de la presencia militar, incluyendo hasta el desalojo de la tropa de las instalaciones de un Batallón en la zona.

En esta trayectoria de la integridad territorial, MENDOZA PALOMINO (1992, p. 116) indica:

es el de Estado-Nación pero los Estados, sobre todo en la Región Andina, son renuentes a aceptarlo". CARLO NASI, director de las especializaciones en Ciencia Política de la Universidad de los Andes, advierte que no existe consenso sobre la "soberanía relativa" y que el "internacionalismo" tiende a ser unidireccional, en el sentido que usualmente sólo algunos países desarrollados tienen los recursos materiales e incentivos para inmiscuirse en los asuntos internos de otras naciones". De ahí que para Colombia abogar por un concepto de soberanía relativa puede incitar intervenciones foráneas no deseables en el futuro. ARLENE TICKNER, de la Universidad de los Andes, señalaba que la nueva doctrina de seguridad de Estados Unidos y su estrategia de guerra preventiva resaltan la idea de que aquellos gobiernos que no controlan la amenaza terrorista en su propio territorio no serán considerados soberanos".

102 Simón Trinidad y Rodrigo Granda, son los alias de los cabecillas del grupo al margen de la ley, FARC, que fueron capturados, el primero en la República de Ecuador y el segundo en Venezuela.

${ }^{103}$ Hechos ocurridos en el mes de marzo de 2008. 
"Así el Presidente decidiría el empleo de las Fuerzas Militares y mediante dicha decisión habilitar las órdenes estratégicas y tácticas, ideadas y concebidas por los mismos militares, según su estructura de mando, recayendo en ellos así la responsabilidad. Pero se trata sólo de una solución práctica y prudente, no constitucional y por tanto queda a la decisión del Jefe de Estado, el asumir el riesgo de lo que tendría características de aventura (...).”

RANGEL SUÁREZ (1999, p. 41) escribió:

"Así las cosas, la feudalización del país y la disolución de la precaria presencia institucional del Estado puede estar llevando a que en la Colombia de hoy existan por lo menos cuatro tipos de municipios aquellos donde aun predomina el Estado, los manejados por la guerrilla, los controlados por los paramilitares, y los que están en disputa."

En contrasentido, pero en cumplimiento de la responsabilidad constitucional y política, interpretado seguramente este concepto, el de la defensa de la integridad territorial y su responsabilidad en desarrollarlo, el periodo de Gobierno 2002-2006, en su Política de Defensa y Seguridad Democrática, (2003, p. 15), expreso:

"Control territorial y acción coordinada del Estado. (...). 13. La primera condición para cumplir con el objetivo de fortalecer el Estado de derecho es la consolidación gradual del control estatal sobre la totalidad del territorio. Sin control territorial por parte del Estado no es posible garantizar el buen funcionamiento de la justicia, entorpecida en muchas regiones del País por la intimidación de las que son víctimas fiscales, jueces y demás autoridades y sin la plena vigencia de la ley, la población, expuesta a las amenazas y al dominio arbitrario de las organizaciones armadas ilegales, pierde el ejercicio de sus derechos y su libertad. 14. La Fuerza Pública iniciará el proceso de consolidación del control estatal sobre el territorio, asegurando su presencia permanente y definitiva en todas las cabeceras municipales."

Para el año 2002 se puede afirmar, entonces, que era evidente la fractura de la integridad territorial del Estado, que aún es tema de discusión en algunas zonas del país; por lo menos así se puede entender, luego de la visita del señor Presidente al departamento del Cauca y de una de las conclusiones de la revista semana (2012, No 1576.), cuando escribe que: "El 
resultado de la visita del Presidente a Toribio fue que el País se dio cuenta que el estado está muy lejos de controlar esa región.” Este tipo de situaciones hacen manifiesta, la importancia y amplitud de la misión de las Fuerzas Militares y la gravitación que tiene esta en la supervivencia del Estado, con mayor razón si se mira desde el punto de vista de los derechos fundamentales, que obliga a los militares a actuar con diligencia y evitar las omisiones que los pueda comprometer con la ley penal, desde el punto de vista de la integridad territorial.

MonTEALEGRE LynetT, en la Sentencia SU-1184 de 2001, desarrolla el concepto de orden constitucional como otra de las condiciones estructurales de la misión constitucional, concibiendo como elementos centrales de éste el cumplimiento pleno de los principios, derechos y deberes consagrados en la Constitución, afianzando esta percepción en el artículo $2^{\circ}$ de la Carta, es decir los fines esenciales del Estado descritos como:

“(...) servir a la comunidad, promover la prosperidad general y garantizar la efectividad de los principios, derechos y deberes consagrados en la Constitución; facilitar la participación de todos en las decisiones que los afectan y en la vida económica, política, administrativa y cultural de la Nación; defender la independencia nacional, mantener la integridad territorial y asegurar la convivencia pacífica y la vigencia de un orden justo.

Las autoridades de la República están instituidas para proteger a todas las personas residentes en Colombia, en su vida, honra, bienes, creencias, y demás derechos y libertades, y para asegurar el cumplimiento de los deberes sociales del Estado y de los particulares."

Lo anterior es mucho más que la simple expresión de la Alta Corte. Significa que la misión de las Fuerzas Militares en el Estado social de derecho es tan amplia, que le implica seguramente analizar, actualizar y reestructurar su misión y el cumplimiento de ella, dando, entre otros, una preparación militar a sus integrantes que les permita actuar precisamente en esos campos que le impone el Estado. No cabe ya el enunciado de que la Institución Militar está sólo de una manera general para el mantenimiento de la soberanía o de la defensa de la 
integridad territorial, es decir que su misión es más fronteriza, o que tal o cual tarea como ya se anotó en el sector urbano o rural corresponde sólo a las fuerzas policiales. ${ }^{104}$

\subsubsection{La obediencia debida}

Es fundamental en el recorrido de la competencia funcional, tratar la obediencia debida por su trascendencia en el cumplimiento de la misión constitucional y por la misma rigidez jerárquica institucional ${ }^{105}$ que enmarcan diversidad de eventos propios del arte militar, donde generalmente está presente la figura de la obediencia, ya sea en comportamientos omisivos o de acción; por tales razones se justifica tratar brevemente algunas de las voces jurisprudenciales y doctrinales existentes, que coadyuven a entender más el verdadero marco y alcance de: a) las órdenes militares; b) la obediencia debida; c) la obediencia reflexiva, d) la obediencia ciega y e) el temor reverencial, para entender estas como posibles laberintos en el quehacer militar, que de no tener la debida claridad, puede colocar a los miembros de la Institución Militar en los límites de los Estatutos Penales. Es claro que la obediencia debida puede conducir a incurrir en omisiones impropias; por ejemplo si el comandante de una patrulla cumple una orden que está dirigida a omitir el cumplimiento de un deber jurídico estando en capacidad de hacerlo, como neutralizar o disminuir un riesgo creado por un agente generador de violencia en una población.

\footnotetext{
${ }^{104}$ El profesor LUIS CARLOS SÁCHICA, en su Tratado de constitucionalismo colombiano, refiriéndose a la institución militar (p. 257), escribió: “(... 6) asimismo, se hace una separación orgánica, entre la Policía encargada del orden interno y el Ejército guardián del dominio territorial frente a extraños para neutralizar la influencia de éste, haciendo la actuación del Ejército meramente ocasional, cuando aquella no es plenamente operante".

${ }^{105}$ Escribió la Corte Suprema: “(...) La estructura burocrática del Estado gira en torno al principio de jerarquización de su órganos en los que unos, por su propia naturaleza, expiden mandatos y otros se encargan de ejecutarlos, quedando por ello el personal sometido a un orden jerárquico determinado por la facultad de mandar y el deber de obediencia. Esta estructura jerárquica reclama, entonces, el establecimiento de formalidades y rigorismos que deben tener las órdenes expedidas para que adquieran un carácter vinculante, del cual se desprenda la posibilidad de determinar responsabilidades penales y disciplinarias, ante su desobedecimiento o incorrecta ejecución. Pero cuando el contenido de una orden sea manifiestamente contrario a derecho, el funcionario público debe abstenerse de cumplirla, so pena de que al realizar la actuación contenida en el mandato se deriven consecuencias punibles, caso en el cual responderá al igual que su superior (...)" ( Proceso 9785 de 1995).
} 
Es usual en el estamento castrense, hacer repetitivas diversas frases relativas a las órdenes militares y su cumplimiento, como aquellas que: "autoridad que no abusa se desprestigia", “donde manda capitán no manda marinero", "el que manda, manda aunque mande mal"; "las órdenes se obedecen o la milicia se acaba", etc., de las cuales generalmente no se tiene conciencia del alcance jurídico-legal que tienen verdaderamente estas expresiones, particularmente a la hora de enfrentarse a acciones u omisiones contenidas en el Código Penal. Estas frases, sin duda, tienen incidencia en el ámbito general que enmarca el concepto de la obediencia debida. Con la sola definición del Diccionario Larousse se le encuentra sentido: dice que el vocablo significa: "Acción de obedecer, costumbre de obedecer, sumisión de una cosa a otra, (Sinón. Acatamiento, subordinación). Precepto del superior en las órdenes religiosas, permiso que da un superior; fig. Obediencia ciega, la prestada sin examinar los motivos o razones".

En virtud del alcance del principio de obediencia debida, de una parte, como pilar de la actividad castrense y de otra, de las implicaciones legales que tiene, cuando la obediencia se materializa en un no hacer de lo que se debía realizar, y tal comportamiento conduce a la violación de los derechos fundamentales o al Derecho Internacional Humanitario, y en general cuando el cumplimiento de una orden es contrario a la ley, es válido refrescar desde la definición básica, hasta las expresiones constitucionales como se ha venido desarrollando y reiterando el concepto de obediencia debida ${ }^{106}$ de acuerdo a las exigencias jurídicas que emanan de la dinámica de la sociedad y de las mismas acciones de las instituciones castrenses.

La definición básica se define así: "Someter a la voluntad ajena y ejecutarla: el soldado debe obedecer a sus jefes (...)" (Círculo de Lectores, 1992). Obsérvese, de una parte, cómo desde la definición básica se involucran las significaciones que tienen la obediencia ciega, y de otra, la expresión de sometimiento de la voluntad del soldado a sus jefes, elementos que son de permanente debate jurídico.

\footnotetext{
${ }^{106}$ Entre otras, se pueden citar las siguientes Sentencias de la Corte Constitucional: T-409 de 1992, C-578 de 1995, C-351 de 1998, C-141 de 1995, C-225 de 1995, SU-257 de 1997, C-551 de 2001, C-317 de 2002 y C431 de 2004.
} 
La obediencia debida y la Constitución Nacional de 1886:

Artículo 21. En caso de infracción manifiesta de un precepto constitucional en detrimento de alguna persona, el mandato superior no exime de responsabilidad al agente que lo ejecuta.

Los militares en servicio quedan exceptuados de esta disposición. Respecto de ellos, la responsabilidad recaerá únicamente en el superior que da la orden".

La obediencia debida y la Constitución Nacional de 1991:

Artículo 91. En caso de infracción manifiesta de un precepto constitucional en detrimento de alguna persona, el mandato superior no exime de responsabilidad al agente que lo ejecuta.

Los militares en servicio quedan exceptuados.

Respecto de ellos, la responsabilidad recaerá únicamente en el superior que da la orden.

La obediencia debida y la Ley 599 de 2000 (Código Penal colombiano):

"Causales de Ausencia de Responsabilidad. Artículo 32. (...) 4. Se obre en cumplimiento de orden legítima de autoridad competente emitida con las formalidades legales.

No se podrá reconocer la obediencia debida cuando se trate de delitos de genocidio, desaparición forzada y tortura.

La obediencia debida y la Corte Penal Internacional:

"Artículo 33. Órdenes superiores y disposiciones legales. 1. Quien hubiere cometido un crimen de la competencia de la Corte en cumplimiento de una orden emitida por un gobierno o un superior, sea militar o civil, no será eximido de responsabilidad penal a menos que:

a) Estuviese obligado por ley a obedecer órdenes emitidas por el gobierno o el superior de que se trate;

b) No supiera que la orden era ilícita; y

c) La orden no fuera manifiestamente ilícita. 
2. A los efectos del presente artículo, se entenderá que las órdenes de cometer genocidio o crímenes de lesa humanidad son manifiestamente ilícitas."

La obediencia debida y la Ley 836 de 2003 (Régimen Disciplinario Fuerzas Militares):

"Artículo 33. Responsabilidad de la orden. La responsabilidad de toda orden militar recae en quien la emite y no en quien la ejecuta.

Cuando el subalterno que la recibe advierta que de su ejecución puede derivarse manifiestamente la comisión de una conducta punible, infracción disciplinaria o fiscal, el subalterno no está obligado a obedecerla y deberá exponer al superior las razones de su negativa."

La obediencia debida y la expresión constitucional en la Sentencia T-363 de 1995:

"La obediencia debida es el principio general al que deben acogerse las relaciones entre superiores y subalternos militares y que solamente en casos de palmaria, evidente e indudable transgresión de los límites constitucionales, mediante órdenes que afecten de modo directo los derechos humanos, es permisible al inferior acogerse a los dictados de su conciencia para hacer que en el caso concreto prevalezcan la Constitución y el respeto a la dignidad humana. Es decir, el inferior no está obligado a la obediencia ciega pero tampoco le es posible cobijar, bajo el amparo de razones puramente subjetivas, la oposición a mandatos que no pugnen con el orden constitucional. Así, en casos como el examinado, ningún sentido tiene el alegato de motivos religiosos o la apelación a las propias convicciones para evadir el cumplimiento de órdenes superiores que no solamente no se oponen a la Constitución Política sino que la desarrollan."

Las órdenes militares, por los vínculos que tienen de frente a los derechos fundamentales, deben ser indudablemente legítimas, y en ese contexto, claras, precisas y concisas. La Corte Constitucional, en la Sentencia C-578 de 1995, manifestó que: "3.2. La materia propia de las órdenes militares es el uso de la fuerza con el objeto de defender la soberanía, la independencia, la integridad del territorio nacional y el orden constitucional (...)"; pero la misma sentencia es rígida en su posición sobre la obediencia debida cuando manifiesta: 
"La doctrina de la Corte Constitucional, desde un principio, ha considerado indispensable que dentro de las fuerzas militares reine un criterio de estricta jerarquía y disciplina, pero ha rechazado como inconstitucional la concepción absoluta y ciega de la obediencia castrense. El principio no absoluto de obediencia debida que prohíja la Corte, no solamente corresponde a la noción aceptada por la conciencia jurídica universal como fruto de la evolución histórica y filosófica de tal concepto, sino que también coincide con el alcance que la doctrina del derecho penal le concede."

$\mathrm{Si}$ se tiene en cuenta la relación estrecha de las órdenes militares con la misión constitucional de las Fuerzas Militares, cabe resaltar los elementos que deben contener una orden militar, como los describe De LA PAVA MARULANDA:

"Que la orden sea emitida por una autoridad pública legítima. Que la orden esté vinculada a un asunto propio del servicio oficial. Que quien da la orden tenga competencia legal. Que exista una relación jurídica de subordinación dentro del servicio público entre el funcionario que emite la orden y el subalterno que la ejecuta. Que el subalterno deba cumplir la orden. Que la orden sea dada con las formalidades legalmente previstas (2007, pp. 57-60)."

En ese mismo contexto aparecen las denominadas órdenes del servicio y que la Corte Constitucional, a través de la misma Sentencia C-578 de 1995 las define claramente como aquellas que tienen una íntima relación con la misión de las Fuerzas Militares, de ahí que resalte cómo órdenes relacionadas con agresiones sexuales y torturas no tienen nada que ver con el servicio. En general en cualquier orden que implique comportamientos tipificados en la ley penal alejadas de la misión castrense se descalifica de tajo la posibilidad de aplicar el principio de obediencia debida y más allá de la aplicación del fuero militar, precisamente por ser órdenes en contra del derecho.

Tenemos entonces que si las órdenes deben tener una íntima relación con el servicio, en otros términos con la misión constitucional, son estas las que deben ser cumplidas sin titubeos, o como lo expresa el Tribunal Constitucional: "con exactitud y sin vacilación". La obediencia es un icono en el quehacer militar, la rigidez de la jerarquía y la disciplina lo impone, la misma Corte lo trae a colación en la sentencia anteriormente nombrada, y en ella 
aclara la diferencia a la hora de analizar la obediencia debida, de un lado en quien recibe la orden, y de otro en quien la emite.

La obediencia ciega es aquella que ejecuta el subalterno sin detenerse a analizar sobre la legalidad de la orden, o que conociendo la ilegalidad de la misma, sin importarle, también la ejecuta. La ley no podrá aceptar este tipo de obediencia ciega como una causal para exonerar de responsabilidad a un militar, cuando salta a la vista que la orden ataca los derechos fundamentales de los asociados. De hecho, el subalterno debe estar en capacidad de entender si la orden que recibe es contraria a derecho. La Corte Constitucional en la misma sentencia, al resolver la acción de inconstitucionalidad del artículo 15 (parcial) del Decreto Ley 85 de $1989^{107}$ (anterior Código Disciplinario FF.MM.), deja absolutamente claro cómo para los miembros de las Fuerzas Militares la obediencia ciega a órdenes que son abiertamente ilegales, es decir aquellas que ponen en peligro o lesionan cualquier bien jurídico, no es eximente de responsabilidad, y por el contrario los coloca frente a la ley penal. En dirección de la Omisión Impropia reviste igual significación. Por ningún motivo la ley ampara la obediencia ciega cuando se está frente a la no realización de un deber jurídico estando en capacidad de hacerlo, ejemplo: cuando se cumple una orden de no atacar a un agente generador de violencia que está poniendo en peligro bienes jurídicos de los ciudadanos, estando en el deber y la capacidad de hacerlo.

Entre la obediencia debida y la obediencia ciega se puede entreverar la problemática, si así se le puede llamar, de la obediencia reflexiva y el temor reverencial. En cuanto a la obediencia reflexiva, es el deber y el derecho que le asiste al subalterno de analizar la orden recibida, no es el concepto de deliberación o de polémica de la orden militar; sería entonces aquella que se le permite, y que estaría obligado el subalterno a poner en práctica, para lograr discernir entre lo que puede y debe obedecer, y aquello que definitivamente la ley se

\footnotetext{
${ }^{107}$ Decreto-Ley 85 de 1989, art. 15. "La responsabilidad de toda orden militar recae en quien la emite y no en quien la ejecuta. Cuando el subalterno que la recibe advierta que de su ejecución puede derivarse manifiestamente la comisión de un delito, acto contra el honor militar o falta constitutiva de causal de mala conducta, debe exponerlo así al superior. Si este insiste, el subalterno está obligado a cumplirla previa confirmación por escrito" (subrayados son originales de la sentencia y corresponden a las partes demandadas).
} 
lo prohíbe, no sólo a éste, sino al mismo superior del que emana la orden (Sentencia C-578 de 1995). La obediencia reflexiva sería aquella que impide la obediencia ciega de una parte, y que conduce a la verdadera obediencia debida. De hecho la Corte en esta sentencia manifiesta:

"El conflicto queda circunscrito a la conciencia del ejecutor de la orden y se plantea en términos de obediencia ciega y obediencia reflexiva, sin trascender a la relación bipolar ejecutor-ordenante. El resultado de la tensión planteada, que considera satisfactoriamente solucionado en la ley, no alcanza a superar la simple manifestación de la conciencia reflexiva, pues, de todas maneras, se impone la orden del superior. En todo caso, el antagonismo o colisión virtual que en esta situación se da entre el obedecimiento al derecho y el obedecimiento a la autoridad que lo desconoce, no se considera. Ignorar los extremos reales de la confrontación - superior e inferior, de un lado y, de otro, imperio del derecho o de la autoridad -, le resta toda coherencia y sentido a esta tesis."

Y más adelante agrega:

"La historia registra el desarrollo y particularidades del principio de la obediencia debida en las diversas épocas y civilizaciones. La tensión autoridad-ley se traduce en una relación jerárquica entre quien ordena y quien obedece. La dialéctica histórica de estos valores, en situaciones límite eventualmente contrapuestos, permite comprender las sucesivas transformaciones de la institución de la obediencia debida, a partir de la sumisión ciega e incondicional del esclavo ateniense hasta la obediencia reflexiva del militar en el Estado Social de derecho."

La figura del temor reverencial, aunque sea notorio en las instituciones militares, en virtud de la rigidez de la jerarquía y disciplina castrense que se profesa en la práctica de la instrucción, del entrenamiento, de las operaciones y en general en todo el quehacer militar, amén de las amenazas (aunque sean silenciosas) permanentes de pérdida de honores, prerrogativas, ascensos y cuando más, el mismo retiro de la Institución, mantienen sobre el subordinado verdaderamente un alto grado de temor reverencial, el cual sin duda tiene connotaciones en el marco de la obediencia debida, aún así, el temor reverencial no tiene ninguna validez como eximente de responsabilidad, y menos cuando se trata de omitir 
comportamientos que permitan ataques a bienes jurídicos como la vida y la libertad. Se puede tomar como ejemplo el caso de un señor oficial del Ejército, que en su condición de Comandante de una unidad militar, acepto su responsabilidad y la justifico en la tolerancia y en el miedo, la presión y otros factores. (Revista Semana, Edición 1524 de 2011, p. 44).”

La Sentencia C-578 de 1995 es una buena orientación en tan vertebral tema sobre la obediencia debida y esta figura no es complejo asimilarla a la Omisión Impropia, pues tanto el que manda como el que obedece, deben estar al tanto de la legalidad de la orden, que no puede estar encaminada a omitir el cumplimiento de un deber jurídico, cuando el uno y el otro saben que están en capacidad de actuar. De hecho, la Corte respalda el imperativo de la obediencia, pero es lo suficientemente clara y precisa sobre la responsabilidad de los militares que cumplan órdenes que ataquen los derechos fundamentales, o que emitan y cumplan órdenes tendientes a omitir la ejecución de una acción militar, ya sea relacionada con los deberes de seguridad en el tráfico o con los deberes de salvamento. Es claro que por ningún motivo la severidad de la obediencia debida dentro de la rigidez de la disciplina militar puede abarcar el cumplimiento de órdenes que conduzcan al incumplimiento de un deber jurídico, al que se está en capacidad de acudir. El subalterno tiene el derecho, el deber, y de otra parte debe tener la agilidad y entereza para marcar su terreno de la legalidad en el contenido de la orden dentro de ese cerco de la disciplina militar.

Ferre Olive, NúÑez PAZ y RAMíreZ BARbosa (2010, p. 391), además de enunciar la obediencia debida como causal de justificación, cuando deviene una orden de un superior, estiman que se deben "distinguir tres clases de órdenes. El inferior puede cometer el delito obedeciendo una orden legítima, una orden ilegítima pero aparentemente legítima o una orden manifiestamente ilegítima”. Son distintas maneras de acercarnos a los supuestos de la legalidad o no de una orden, y a la necesidad de la obediencia debida. En este orden de ideas, pero terciando hacer claridad sobre la omisión, la Corte Constitucional en la Sentencia SU-1184 de 2001, planteó la siguiente pregunta: ¿Cuándo una omisión de la Fuerza Pública puede ser considerada un acto fuera del servicio? La relaciona directamente 
con los mismos casos en que la acción es un acto fuera del servicio, y hace tres planteamientos de omisión, a saber:

“i) las que se producen en el contexto de una operación que ab initio buscaba fines contrarios a los valores, principios o derechos consagrados en la Carta (surgió para capturar arbitrariamente a alguien y no se impide la vulneración de este derecho) o ii) las que surgen dentro de una operación iniciada legítimamente, pero en su desarrollo se presenta una desviación esencial del curso de la actividad (no se impide el maltrato de una persona que ya no presenta ninguna clase de resistencia en un combate) o iii) cuando no se impiden las graves violaciones a los Derechos Humanos o al Derecho Internacional Humanitario (un miembro de la fuerza pública que tiene el deber de evitar un daño a la población civil, no evita la producción del resultado). En los anteriores casos, siempre es indispensable que el garante tenga dentro de su ámbito de competencia el deber concreto de evitar los resultados que vulneran los derechos fundamentales."

El inferior puede cometer el delito obedeciendo una orden manifiestamente ilegítima pero aparentemente legítima, o las que se refieren a una orden lícita pero que en su ejecución se lleva a cabo una ilícita y ésta esté dirigida a las órdenes que tienen como fin cumplir con deberes jurídicos que tienen relación directa con la protección de los Derechos Humanos o el Derecho Internacional Humanitario. En este contexto del que ordena y el que obedece, en el de la orden legal o ilegal, el derecho penal, además de hacer efectivo el principio como dogma, exige de los operadores la prueba de que en efecto o el superior está dando una orden legal y el subalterno hizo lo ilegal, o que uno y otro actuaron de manera contraria a derecho.

\subsubsection{De la competencia territorial}

La inmensa extensión territorial del país ${ }^{108}$ se enfrenta a una Fuerza Pública con deficiencia cuantitativa por kilómetro cuadrado, teniendo en cuenta la problemática del conflicto interno en la dinámica entre factores generadores de violencia y los grupos al

\footnotetext{
${ }^{108}$ [(1.148.748 km² aproximadamente, y marítima: $928.660 \mathrm{~km}^{2}$, correspondientes a $589.560 \mathrm{~km}^{2}$ en el océano Atlántico y $339.100 \mathrm{~km}^{2}$ en el Pacífico para un total de más o menos $2.077 .408 \mathrm{~km}^{2}$, con unos extensos límites fronterizos definidos así con: Venezuela, $2.219 \mathrm{~km}^{2}$, Brasil, $1.645 \mathrm{~km}^{2}$, Perú, $1.626 \mathrm{~km}^{2}$, Ecuador, $586 \mathrm{~km}^{2}$ y Panamá $266 \mathrm{~km}^{2}$ )]
} 
margen de la ley que se aprovechan de ellos. Lo anterior desde el punto de vista de la amplitud territorial coloca en serias dificultades a un comandante militar a la hora de recolectar las informaciones, procesarlas y tomar las decisiones pertinentes, pues sus jurisdicciones son proporcionales a la extensión territorial del país y no a la cantidad de hombres a su mando y a los recursos humanos y materiales constitutivos de las capacidades materiales que exige la edificación de la posición de garante. Puede afirmarse entonces desde ahora que excepcionalmente son suficientes los recursos humanos y materiales frente a la extensión territorial bajo el encargo de un Comandante.

En el cuadro de la competencia territorial naturalmente la institución militar fija unos límites un tanto aproximados (jurisdicción militar) a cada comandante en el nivel nacional, estratégico, operativo y táctico. Dicho de otra manera, cada comandante de teatro de operaciones, de división, comandante de brigada, de batallón, de compañía y muchas veces hasta los comandantes de pelotón tienen una jurisdicción asignada para que ejerza su capacidad funcional y territorial.

Entonces el planeamiento y ejecución de operaciones en este segmento de la competencia territorial tiene serios inconvenientes, en ese contexto de creación de riesgos y operaciones de salvamento, particularmente por las características topográficas del territorio, las cuales se hacen más notorias cuando no hay conocedores del terreno, cuando no coincide lo analizado en la fase de planeamiento con lo que se encuentra en el área de operaciones, y más cuando los accidentes del terreno son mucho más limitantes operacionalmente de lo calculado. En esta misma dirección, dentro de la competencia territorial, se debe contar, además, con la capacidad del material bélico del grupo al margen de la ley, también inciden las distancias, las características del terreno y las condiciones meteorológicas del territorio en que se presenta el peligro o el ataque de los bienes jurídicos; la competencia territorial tiene relevancia en la posibilidad de apoyo de fuegos aéreos o de artillería, afectan el suministro de los abastecimientos en todo orden, y de remate el terreno es decisivo a la hora de cumplir labores humanitarias terrestres o aéreas para la evacuación de capturados, heridos o muertos, factores, entre otros tantos, que impiden o limitan el cumplimiento del 
deber jurídico de actuar, aún cuando la disponibilidad de recursos materiales y humanos revelen la posibilidad de hacerlo. Como ejemplos, una unidad de combate puede estar lista para actuar, pero el tiempo atmosférico no permite el vuelo de aeronaves para realizar el desembarco; en otra situación, una unidad de combate puede avanzar a cumplir un deber jurídico pero la creciente inesperada de un rio no le permite continuar o como en ocasiones puede suceder que el poder de combate del enemigo o su posición en el terreno obligan al comandante a reestructurar una operación.

Pueden consignarse algunos ejemplos donde ha incidido el factor territorial en acciones y omisiones:

- En el caso Jamundí, el 22 de mayo de 2006, se generó una investigación penal por los hechos ocurridos en el área general de Potrerito, del municipio de Jamundí, (Valle del Cauca), donde resultaron muertos 10 policías y un particular. Se rescata de los hechos, como ejemplo, lo relativo a la importancia de clarificar en todo momento la jurisdicción que se le asigna a cualquier unidad, en este caso un grupo de agentes de la Policía penetró en el sector asignado a una patrulla del Ejército, como consecuencia hubo un enfrentamiento que arrojó un saldo de 10 agentes y un particular muertos.

- El caso Las Delicias, lugar donde ocurrió el asalto guerrillero a una base militar en agosto de 1996, las operaciones de salvamento no fueron exitosas, entre otros aspectos por las condiciones del terreno.

- Como se anotó anteriormente el asalto a la base militar de Patascoy (Departamento de Nariño), ocurrida el 21 de diciembre de 1997, donde se presentó el homicidio y secuestro de varios integrantes del Ejército Nacional, es otro ejemplo de las incidencias que tienen las condiciones topográficas y atmosféricas a la hora de no poder cumplir con el deber jurídico de impedir el resultado que pertenece al comportamiento descrito en el artículo 25 del Código Penal; precisamente el factor 
poder queda relativizado con respecto a las variables de tiempo atmosférico, topografía y espacio en el cumplimiento de la labor del agente que tiene a su cargo la protección de los bienes jurídicos.

- En el caso Mapiripan la Sentencia SU-1184 de 2001 debatió la problemática de la responsabilidad territorial; había en la jurisdicción dos Brigadas del Ejército, las cuales se vieron involucradas en el proceso penal.

Si se profundiza el estudio de estos casos, para no citar más, se encontrará que el factor territorial no solo incide y limita, sino que puede impedir el poder de ejecutar acciones de salvamento, lo que un desprevenido operador jurídico sin conocimiento alguno en el quehacer militar juzgaría a priori, y sin fundamento edificaría la posición de garante sobre el militar implicado. La competencia territorial debe ser ejercida en todo su contexto por el responsable directo y no adherirse sin razón ni causa al superior jerárquico, quien no puede responder por lo que sus hombres hagan o dejen de hacer, a no ser que hayan recibido requerimientos tendientes a superar limitaciones en su territorio y que aquel tenga el poder

para suplirlas; de otra parte, la competencia territorial debe estar plenamente demarcada, pues las especiales circunstancias de tiempo, modo y lugar en que se presentan las situaciones de desorden público y las exigencias del Derecho Internacional Humanitario en cuanto a la protección de la población civil, colocan a los militares en posiciones difíciles frente al Delito de Omisión, no sólo para actuar frente a amenazas contra la población, sino además para sus propias tropas.

\subsubsection{Los límites de tiempo}

Con miras a tratar de extender el estudio de la posición de garante como eje de la Omisión Impropia, en el recuadro de los límites de tiempo, referido a los términos para actuar, reaccionar o las razones para omitir, las tres diferenciaciones de ANDROULAKIS, englobadas con acierto por PERDOMO (2001), en el concepto funcional de proteger a determinadas personas como de vigilar o controlar fuentes de peligro, se pueden resumir en el 
cumplimiento de los deberes de seguridad en el tráfico y los deberes de salvamento, lo que tiene especial notoriedad, mucho más si se ensamblan con factores que influyen decisivamente en el quehacer de los militares, para poder cumplir con el deber legal de actuar ante las amenazas y ataques a los bienes jurídicos. Debe considerarse que las amenazas a bienes jurídicos por lo general se presentan a distancias considerables y los objetos que generan peligro generalmente están cargados de explosivos que afectan el avance de las patrullas que tratan de acercarse. Estos dos aspectos, sumados a otros que resumidos se presentan como las condiciones topográficas y meteorológicas, aunado al poder de combate del enemigo, generalmente inciden, limitan o impiden en el poder de acción de las tropas, en ese marco de los límites de tiempo.

En el análisis de la posición de garante es importante hacer consideraciones relativas a los límites de tiempo, pero esta vez referido a lo meteorológico y a lo temporal propiamente dicho. La doctrina militar en el área estratégica y táctica dedica suficiente información a estos aspectos; en ocasiones esos factores pueden constituirse en gravitantes a la hora de la seguridad en el tráfico o de omitir una acción de salvamento, donde además del factor temporal, la topografía e hidrología son factores determinantes, causantes del retardo en la ejecución de operaciones o del apoyo a las tropas; como ejemplo en el caso Las Delicias los límites de tiempo seguramente, o no fueron valorados, o si se hizo, no se ejecutó con la exigencia doctrinal castrense. El tiempo atmosférico tiene mayor incidencia a la hora de realizar distintos eventos en las zonas de operaciones: en transporte de tropas por vía terrestre, aérea, fluvial o marítima, el tiempo atmosférico a la hora de ejecutar vuelos de reconocimiento o de apoyo de fuegos, también es determinante para el suministro de los abastecimientos.

Estas, entre otras, son las acciones que pueden impedirse o limitarse por el tiempo atmosférico, son las que pueden tener connotaciones en el marco jurídico, y son estas situaciones las que exigen de los militares que sus actos administrativos, como las llamadas apreciaciones de situación y las órdenes de operaciones, sean detalladas en cada uno de los campos y permanentemente actualizadas. De los ejemplos citados en la competencia 
territorial, quizá en los que mejor se puede apreciar las incidencias de los límites de tiempo, tanto el atmosférico como el temporal propiamente dicho, es en el caso Las Delicias y en Patascoy. El factor tiempo en los dos sentidos atmosférico y del reloj limitaba unas acciones e impedía otras relacionadas con el movimiento de las tropas y el apoyo de las mismas. Además de que el comandante no estaba cerca de los bienes jurídicos amenazados, en este caso, de la tropa que requería la defensa de sus bienes jurídicos, consecuencialmente tampoco se estaba cerca de las personas que atacaban los bienes jurídicos con los agravantes precisamente de los límites de tiempo.

\subsubsection{Los límites de espacio}

Clausewitz (1999, p. 216), al hacer la consideración de la concentración de las fuerzas en el espacio, escribe:

"Parece increíble, y sin embargo ha sucedido ciento de veces, que unas fuerzas puedan haber sido divididas y separadas solamente a causa de una adhesión nebulosa a ciertas costumbres tradicionales sin que se supiera claramente la razón por la cual se actuaba de esta forma."

Por la dinámica de las acciones que se llevan a cabo en la dinámica del conflicto interno, frecuentemente se realizan traslados de tropa para cubrir necesidades cuantitativas y cualitativas que tienden vigilar y proteger a la población civil, esta misma circunstancia hace que periódicamente queden al descubierto zonas del territorio que corresponden a determinados batallones o brigadas, en estos dos eventos, además, surge el problema que los actos administrativos que justifican los movimientos no se ejecutan paralelamente, lo que crea vacios de responsabilidad en cuanto a la protección de bienes jurídicos de la población civil o de las tropas en determinadas zonas.

La estrategia y la táctica, en especial la última, son rígidas en el manejo de estos conceptos tanto en el ámbito de la guerra regular como de la irregular; sin embargo las características topográficas del país las vuelven no tan rigurosas, razón por la cual el desarrollo de estas 
normas reglamentarias deben ser objeto de continuo seguimiento, no son estáticas, son normas dinámicas. A manera de ejemplo, a la llegada de una Unidad a una jurisdicción en conflicto, sea por agregación, por refuerzo o en cumplimiento de tareas específicas, se sugiere puntualizar la responsabilidad en cuanto al espacio en el cual ejecutará sus acciones militares. Aún con las dificultades propias del conflicto en los actos administrativos se deben asignar las jurisdicciones definitivas o temporales, y concretarlas de tal manera que demarque la responsabilidad a los comandantes. No es menos importante la claridad de este elemento espacial, en los casos de operaciones conjuntas (por ejemplo: el llamado plan democracia), donde interviene la Policía Nacional, en estos casos, la responsabilidad de protección de bienes jurídicos se diversifica y se multiplica, lo que debe hacer más rígido el cumplimiento de las órdenes e instrucciones que emane de los comandos responsables. (Caso Jamundí, 22 de mayo de 2006).

Los límites de espacio ofrecen frecuentemente inexactitudes, aún a expertos militares en operaciones, con mayor razón son mayúsculas las equivocaciones en que suelen incurrir los funcionarios de justicia, que colocan al descubierto lo fundamental, dispendioso y necesario que es el análisis y conocimiento del tema militar, no por menos, respetando los conceptos de PERDOMo (2001, pp. 41 y ss.) cuando, como se anotó antes, quien estudiando la posición de garante, cita a ANDROULAKIS y establece las tres diferenciaciones ya anotadas no entendidas como métrica o espacial, sino desde la óptica de la cercanía social: a) cerca de la persona amenazada por el peligro; b) cerca del autor de la lesión al bien jurídico, y c) cerca a la cosa que genera el peligro. PERDOMO, como ya se anotó, las engloba con acierto en el concepto funcional de proteger a determinadas personas y de vigilar o controlar fuentes de peligro.

Se encuentran apropiadas las tres diferenciaciones enunciadas, para acomodarlas en el quehacer de las Instituciones Castrenses, escenario en el cual, y en concreto en las operaciones militares, lo métrico y lo espacial son gravitantes, mucho más cuando se le suman factores topográficos, climatológicos, de transporte aéreo, fluvial, marítimo o terrestre, y en especial aquellos que conciernen al armamento convencional y artesanal y a 
sus efectos. Generalmente las personas (población civil o tropa) amenazadas por el peligro están distantes; frecuentemente los sujetos (los grupos al margen de la ley, la tropa que está en combate o los dos al tiempo) que colocan en peligro el bien jurídico están distantes, y en cuanto a la cosa que genera el peligro del bien jurídico (un artefacto explosivo) estos, mucho más que la distancia donde se encuentran, dentro del terror, está la incertidumbre, la expectativa y la duda sobre la posibilidad de desactivarlo, destruirlo o activarlo controladamente.

\subsubsection{La competencia material}

La descripción típica de la Omisión Impropia exige, además del deber jurídico de impedir un resultado, la posibilidad de hacerlo que es la significación del "poder", en el cual está inmersa la capacidad material que tiene el garante, como parte integral de la posición prevalente.

En este componente del tipo, teniendo en cuenta su condición de norma general (tipo abierto) la posibilidad de hacerlo es de gran significación en la construcción de la posición de garante. La capacidad material vista jurídicamente por operadores de justicia sin conocimiento de la función militar es observada frecuentemente con bastante superficialidad sin detenerse en la variedad de factores que tienen bastante incidencia en este aspecto para poder edificar con certeza la posición de garante, en ese curso están presentes, entre otros, variables como el análisis del enemigo, del tiempo y del terreno.

Es importante aclarar aquí, que la referencia que se hace de la Sentencia SU-1184 de 2001, e desde el punto de vista académico, pues se desconocen las piezas procesales, luego algunas citas servirán para ir más allá del formalismo de enunciar artículos o de hacer conjeturas. Se trata de resaltar las dificultades para asignar la posición de garante cuando se tiene un mejor conocimiento del arte militar. Así las cosas, en aras del debate, se menciona como ejemplo lo que afirmó la Corte Constitucional en la sentencia en comento respecto a la capacidad material: 
"Se atribuye a dos miembros de la Fuerza Pública que tenían competencia material, funcional y territorial sobre la zona (posición garante), que frente a la agresión armada contra la población civil (situación de peligro generador del deber) no prestaron ningún tipo de ayuda (no realización de la acción esperada) cuando contaban con medios materiales para hacerlo (capacidad individual para realizar la acción)."

Más adelante el mismo Tribunal, refiriéndose al "fuero y omisión”, escribe:

"Si el miembro de la Fuerza Pública tiene un deber específico de evitar el resultado (ostenta una posición de garante) y no inicia la acción de salvamento a pesar de que contaba con la posibilidad material de hacerlo (tenía a su disposición medios logísticos para la protección de los bienes jurídicos), se le imputa el resultado lesivo que no impidió y no la simple inobservancia de un deber funcional."

La providencia que se demandó y que estudió la Honorable Corte Constitucional, advirtió que: "Así mismo, en la misma providencia se da cuenta de que los procesados tenían a su disposición «los helicópteros, caminos, automóviles, armamento y todo el personal de oficiales y suboficiales que hacía parte de las guarniciones (...)”.

Como de la competencia material se trata, y es tema sensible con relación a la posición de garante, vale la pena en este espacio hacer unas claridades respecto a lo manifestado por el alto tribunal: por ejemplo, en cuanto a los "automóviles", que para el caso de las operaciones militares se debe imponer la diferencia, ya que una cosa son los automóviles que se pueden emplear para movimientos en campos abiertos como avenidas y carreteras, y otra cosa bastante distinta son los "vehículos" que se requerirían para las trochas, propias de la geografía nacional y para que se desempeñen en operaciones militares. Lo cierto es que la simple definición de un Diccionario como el Larousse y el Diccionario Militar Estratégico y Político difieren significativamente; el Diccionario Militar contempla el "vehículo todo terreno", y lo define como: "el diseñado para poder caminar por cualquier tipo de terreno, estando dotado de un motor de gran potencia y de una suspensión, ejes articulados y ruedas especiales", como los vehículos todo terreno, los vehículos de cadena y los vehículos anfibios, entre otros. En este mismo sentido, respecto a la presencia de 
helicópteros en una guarnición, este solo hecho no garantiza su posibilidad de empleo para operaciones militares; son variadas las causas por las cuales las aeronaves pueden mantenerse en tierra: por limitaciones en la tripulación, por limitaciones de las aeronaves para el uso (no están adecuadas para la misión que se requiere), por mantenimiento o por limitaciones meteorológicas, entre otras. En lo referente a que se tenía "todo el personal de oficiales y suboficiales", se deben conocer cuáles son las dotaciones que han de poseer las distintas unidades de las Fuerzas Militares, y las mismas capacidades que están en posibilidad de realizar; referente a las dotaciones es un aspecto que está muy bien definido en la estructura organizacional de la Institución, donde existen unas tablas de organización y equipo ${ }^{109}$ que le asigna a cada unidad una dotación de recursos humanos y materiales para el cumplimiento de la misión, se puede expresar que estas tablas son poco conocidas por la comunidad jurídica, por ejemplo: los batallones por lo general presentan déficit especialmente en el personal de oficiales y suboficiales, y mantienen a sus tropas dispersas en su jurisdicción, por lo tanto no todo el personal de un batallón está disponible para enfrentar un ataque a bienes jurídicos, y realizar operaciones de salvamento, como en los casos de asaltos a poblaciones.

En la misma dirección de las capacidades materiales, y en este marco en concreto referente al poder, es de trascendencia para la Institución Militar enterarse y ocuparse del contenido de las afirmaciones del Presidente del Consejo de Estado en entrevista posterior a los polémicos fallos administrativos sobre el caso de las delicias. Manifestó que: "Este fallo no es novedoso, solo consolida una jurisprudencia de hace muchos años: que los comandantes militares que deciden enviar a los hombres a cumplir las misiones deben hacerlo con estricto acatamiento a las instrucciones y reglamentos que los rigen y con todos los recursos" (El Tiempo, junio 04 de 2011).

De un lado, se puede afirmar que estas aseveraciones son el resultado de los análisis $e x$ post, con bastante desconocimiento del conflicto, con serio desconocimiento del tema

\footnotetext{
${ }^{109}$ Las "tablas de organización y equipo" asignan ordenada y detalladamente cuáles son los recursos humanos y materiales a cada unidad del Ejército. Se supone que éstos son los mínimos con los cuales el Estado debe dotarlos para el cumplimiento de la misión.
} 
operacional, y por lo tanto, deficiente aplicación de figuras dogmáticas a las acciones de las tropas y a los actos de barbarie de los grupos al margen de la ley, y de otro lado, la necesidad de que los mandos militares, precisamente fundamentados en los argumentos de las Altas Cortes, replanteen las normas respecto a las capacidades materiales de las tropas que se ubican distantes, precisamente por urgentes necesidades de proteger los bienes jurídicos de la población.

Pero estos no son los únicos problemas, generalmente en la estructura militar se lleva a cabo un rígido proceso de planeamiento de operaciones, entre otros, se realiza una comparación del potencial propio con el del grupo al margen de la ley que ataca la población, en la que se incluye el análisis de personal y el de la capacidad material propia y la del adversario; Igualmente, la Institución realiza el estudio de las llamadas necesidades, disponibilidades y limitaciones, las cuales traducidas al lenguaje jurídico hacen parte medular de las capacidades materiales. Si así se considera esta comparación, la apreciación de situación que haga un comandante militar debe realizarla minuciosamente para que, en caso de necesidad jurídica, tal documento como acto administrativo materialice una prueba de relevancia penal.

A la competencia material se le pueden asignar distintos recursos con la posibilidad de utilizarlos en defensa de los bienes jurídicos puestos en peligro o atacados, por ejemplo, en las mal llamadas toma de poblaciones (¿es terrorismo?) de nada sirve tener aeronaves con posibilidad de ataque, si el enemigo está concentrado en una población usándola como escudo; de nada sirve tener disponible sofisticado equipo aéreo con su armamento, si las condiciones atmosféricas no permiten su empleo; de nada sirve tener tropa altamente especializada para acudir a una acción de salvamento si las mismas condiciones atmosféricas impiden su acercamiento donde están en peligro los bienes jurídicos; de nada sirve un alto entrenamiento de los hombres y una elevada capacidad en armas de acompañamiento, morteros, ametralladoras, si la cercanía de la población civil impide su empleo. Como estas, son muchas las situaciones que se pueden citar. 
La observación y análisis de estos elementos son una manera sencilla de presentar al operador jurídico, que no basta con determinar algunas generalidades para concluir a plumazo limpio que sí se tenían las capacidades materiales para enfrentar el peligro creado por un tercero.

En cuanto a la clase de unidad que debe acudir en defensa del bien jurídico puesto en peligro o que está siendo vulnerado, es dable asegurar que es bien distinto acudir o determinar el empleo de una Unidad de Infantería, que una Unidad de Ingenieros, o el de una Unidad de Contraguerrillas al de una Unidad de Artillería. Para tratar de explicar este aspecto se hacen las siguientes aclaraciones: la unidad de contraguerrillas combate a los guerrilleros, la unidad de artillería puede proveer apoyo de fuegos a ese batallón de contraguerrillas, y la unidad de ingenieros está en capacidad de facilitar la desactivación de campos minados o facilitar el cruce de un río. Indudablemente y por lo afirmado anteriormente el material de dotación es distinto y el mismo recurso humano ofrece marcadas diferencias a la hora de emprender una acción salvadora. Reaccionar ante el ataque a los bienes jurídicos de una población (situación de peligro generador del deber) con un grupo de soldados bachilleres ${ }^{110}$ es absolutamente imposible, pero es acertado hacerlo con una unidad de contraguerrillas de experimentados soldados profesionales dotados de armamento especial y receptores de un entrenamiento acorde con su especialidad, lo que sucede es que no siempre hay disponibilidad inmediata de este tipo de Unidades. Consecuencialmente difiere el equipo especializado requerido y no se puede dejar de anotar que el espacio territorial de cada tipo de unidad, acorde con la acción esperada que se proyecte tiene unas exigencias de material, en muchos casos especializado. En esa ruta del tipo de operación que se quiera realizar pueden citarse ejemplos como: "no hay asalto aéreo sin helicópteros", "no hay desembarco de paracaidistas sin aviones" y "no hay apoyo de fuegos sin las armas requeridas", para solo citar unos ejemplos.

\footnotetext{
${ }^{110}$ Los militares lo saben, los operadores de justicia no mucho, pero es importante conocer las distintas clasificaciones que se ha hecho del soldado: los hay campesinos, regulares, bachilleres voluntarios y profesionales.
} 
El otro elemento señalado, sobre el conocimiento de la capacidad del enemigo que está atacando o colocando en peligro los bienes jurídicos, es componente central, pues de las capacidades de éste se selecciona personal y material para contrarrestar las amenazas a los bienes jurídicos. La dificultad del asunto radica en las sorpresa que generalmente recibe la tropa y que cuando no la hace retroceder hace replantear el apoyo, y en otras oportunidades que en definitiva se lanza la protección a la población, entonces surgen los delitos contra la vida, sea de militares, sea de población civil (¿daños colaterales?) o ya sea de los subversivos, y entonces entran las decisiones facilistas sobre el empleo desmesurado de la fuerza y todos aquellos señalamientos que surgen y se hacen desde la trinchera del escritorio. Tampoco es fácil advertir el conjunto de las capacidades terroristas: cantidad de hombres, entrenamiento que recibieron, armamento que poseen y características y cualidades del cabecilla que dirige la puesta en peligro de los bienes jurídicos, entre otros, capacidades que sin duda tienen notabilidad en las decisiones de acción o de omisión de quien tiene el deber jurídico de evitar un resultado.

En este contexto, se puede citar algunos ejemplos: el caso "El Porroso" (08 de febrero de 2005), donde como antes se explico, un oficial subalterno tomó la decisión de atacar al enemigo convencido de conseguir un acierto, pero éste es conducido rápidamente a una zona de aniquilamiento (Ya explicado este concepto) ${ }^{111}$ y sufre la pérdida de su vida y la de 19 compañeros; ocurrió en los lamentables hechos ya tratados en la competencia funcional.

Referentes al asalto a la base militar de Las Delicias ${ }^{112}$, evento en el cual las Fuerzas Militares carecían de equipo aéreo con capacidad para realizar los vuelos nocturnos, y el equipo fluvial con el que se disponía tampoco tenía las capacidades para efectuar el desplazamiento nocturno (más o menos seis horas de desplazamiento por río). La tropa no tenía el suficiente entrenamiento para hacer los desplazamientos nocturnos, sean aéreos o

\footnotetext{
${ }^{111}$ Como ya se explico, zona de aniquilamiento se denomina a una parte del terreno que ha sido previamente establecido por el enemigo para conducir allí a una patrulla militar y obligarla a combatir en total desventaja.

${ }^{112}$ El 30 de agosto de 1996 decenas de guerrilleros del Frente Sur de las FARC (Cuadrillas 13, 14, 15, 48 y 49), armados con morteros, granadas de mano y fusiles atacaron la base militar de Las Delicias, donde hubo 26 muertos, 17 heridos y 60 desaparecidos (En: Diario El Tiempo, Sección Justicia, 03 de septiembre de 1996).
} 
fluviales, lo que finalmente influyó e impidió el cumplimiento a los deberes de salvamento ante el ataque de los bienes jurídicos del grupo al margen de la ley.

Es imposible cerrar este capítulo sin hacer un breve análisis del reciente fallo del Consejo de Estado respecto al revés militar sufrido por el Ejército en la base militar de Las Delicias, hechos sucedidos en agosto de 1996, en el municipio de La Tagua, departamento del Putumayo. De este desafortunado episodio se puede rescatar la importancia de los distintos aspectos hasta aquí tratados en relación con la posición de garante y sus puntas, representadas en el deber jurídico y en el poder, este último constituido por las capacidades funcionales, materiales y territoriales.

En primera instancia se puede afirmar que el eje central de la justificación de la presencia de la tropa en ese sector del país, era el cumplimento de la misión constitucional del Ejército, en el marco de los artículos 217 y $2^{\circ}$ de la Norma Superior, en el entendido que se encontraban protegiendo las personas de esa región de Colombia en su vida, honra, bienes, creencias y libertades, y asegurando el cumplimiento de los deberes sociales del Estado y de los particulares, como parte esencial del cumplimiento de las funciones que le obligaban a cada uno de los comandantes en sus respectivos niveles. Lo que seguramente se cuestiona, es si en el desarrollo del cumplimiento de las funciones en los distintos escalones se acataron las exigencias militares que implica la permanencia de una unidad de combate en las circunstancias de amenaza por parte de los grupos al margen de la ley, aspecto que es de doble vía: la una, lo que pida el comandante de la zona, y la otra, los apoyos que entregue el superior inmediato ante los requerimientos del subalterno o las actividades que surjan por iniciativa propia, tanto del superior como del subalterno.

El análisis de la competencia territorial, como parte de la problemática de la posición de garante, puede girar en torno a la incidencia de las distancias para cumplir con el deber de salvamento en virtud del riesgo creado por un tercero (grupo al margen de la ley), porque el riesgo no se puede considerar creado por la Institución, como se hizo en la sentencia. Con seguridad, los factores que impidieron y limitaron los desplazamientos de la acción 
salvadora para los bienes jurídicos de la tropa fueron los obstáculos propios de la naturaleza: los ríos existentes y la carencia de carreteables para minimizar las distancias. Sin duda, los límites de tiempo y de espacio tuvieron influencia en la posibilidad (poder) de ejecutar la acción salvadora (el deber). Factores de tiempo, no sólo en cuanto hace referencia a horas y días, es decir a la distancia a cubrir para lograr la protección de los bienes jurídicos amenazados, sino también a los límites que impusieron las condiciones atmosféricas de la región.

Sólo a manera de ejemplo, obsérvese lo escrito por la Inspección General de las Fuerzas Militares con motivo de tales hechos, y que es utilizado en el contexto probatorio de la Sentencia del Consejo de Estado del 25 de mayo de 2011. Dice la sentencia que: “(...) i) En cuanto al terreno se dijo que «se presenta plano, pantanoso por la misma situación de las lluvias y selvático en un 95\%. No hay vías terrestres de comunicación y todos los movimientos se deben hacer por ríos y caños o por vía aérea (fol. 240)”.

La competencia material, por lo menos para la época, podría afirmarse que era precaria, especialmente en virtud de la falta de equipos de todo orden como armamento, comunicaciones, etc., que permitieran sostener y apoyar una acción defensiva por el tiempo necesario mientras se hacía efectiva la acción de salvamento. De otro lado, es viable el análisis, aún ex post, si los obligados a acudir en protección de la vida y la libertad de los integrantes de la base militar habían requerido a los escalones superiores las necesidades que tenían para una eventualidad como la presentada. En este acápite fue fácil encontrar en la sentencia en comento del Consejo de Estado, un aparte de las mismas comunicaciones que se dieron entre los militares comprometidos en la acción y en la supuesta omisión que acusa el Tribunal Contencioso:

"vii) La acción de los comandos involucrados en la situación, (...) Al momento de producirse el ataque el Comandante del BISEL 49 desarrolló la siguiente actividad: (...)

A las 20:10 horas informó (sic) al C.O.E. manifestándole al Señor Mayor Saavedra que no era un hostigamiento normal sino fuego nutrido de granadas de fusil y de mortero y que solicitaba el ametrallamiento aéreo. En forma inmediata envío el 
radiograma $\mathrm{N}^{\circ} 2630$ dando las coordenadas del sitio. Aproximadamente a las 21:00 horas el Señor Teniente Coronel Bastidas volvió a llamar al C.O.E. al señor Mayor Saavedra solicitando nuevamente el ametrallamiento y la iluminación obteniendo como respuesta que estaban haciendo lo posible para enviar el apoyo ya que el TAC-47 y los otros medios de apoyo se encontraban atendiendo otros tres casos delicados en el área general del Guaviare, el Señor Mayor Saavedra informó al Comandante del Batallón que le informaría tan pronto como saliera el apoyo. Posteriormente el Comando del Batallón se comunicó con el Señor Capitán de Fragata Sánchez, Comandante Encargado de la Fuerza Naval del Sur, para solicitarle el apoyo de un elemento de combate fluvial y las dos cañoneras de la flotilla que se encontraba en La Tagua con el fin de enviar apoyo en las primeras horas del día siguiente a la Base Militar de Delicias. El Señor Capitán de fragata le ofreció toda su colaboración manifestando que el elemento fluvial se retardaba un poco ya que tenía que trasladarlo desde Puerto Leguízamo hasta La Tagua por tierra para colocarlos sobre el río Caquetá y que iba a dar la orden inmediata de alistar las cañoneras. (El subrayado es mío.)

C. FUERZA AÉREA

Programo (sic) el apoyo aéreo con una escuadrilla de dos (2) aviones OV-10, los cuales llegaron a las primeras horas del día 31 de agosto/96 al sitio del ataque, pero por limitaciones en las comunicaciones no pudieron efectuar el apoyo requerido (fls. 248 y 249, subrayado fuera de texto).

Más adelante transcribe el Tribunal:

En el resumen del desarrollo del ataque corroboró lo manifestado en el informe del Mayor General Alfredo García R (fls. 267 a 277).

Al analizar la operación y la actuación de las tropas, se señalaron los siguientes aspectos negativos:

a) La infraestructura organizacional, la escasez de medios, las distancias y condiciones geográficas del CUS, como organización militar en las actuales circunstancias de guerra no le permiten ejercer el mando en la forma que se requiere.

(...)

c) El dispositivo de las unidades en el área no permitía el apoyo y/o reacción.

d) La ubicación y misión de la base, no justificaba su permanencia, como tampoco sus resultados operacionales. 
e) No existía disponibilidad a nivel de Unidad Operativa Mayor (CUS), de una reserva para empleo inmediato.

$(\ldots)$

1) Se presentaron fallas en el armamento (Fusiles G3), a pesar de que algunos de ellos habían sido cambiados. La situación de lluvia y pantano en las trincheras facilitó esta anomalía" (fls. 277 y 278 cp.).

De las mismas revistas e informes de los miembros de la Institución Militar, es que surgen las conclusiones del Consejo de Estado, entre las cuales se pueden destacar:

“... Y es atribuible el resultado dañoso, porque lo determinante en su producción está constituido en i) la omisión del Estado de haber adoptado todas las medidas razonables para prevenir la violación de los Derechos Humanos de las que fueron objeto los ciudadanos-soldados, y ii) porque fue el Estado el que creó la situación objetiva de riesgo ${ }^{113}$ (comprendida por la existencia de la Base Militar de Las Delicias en un ámbito espacial, de orden público y de posibilidades de defensa y protección limitada, como se aceptó), sin que hubiera desplegado los deberes de salvamento, apoyo y protección suficiente al que estaba obligado por expresos mandatos constitucionales, como se señala en el deber de proteger el territorio y los ciudadanos frente a todo tipo de agresión interna o externa. Concretamente, el Estado creó la situación objetiva de riesgo en atención a los siguientes factores: i) la falta de preparación y de entrenamiento en los días anteriores al ataque guerrillero, lo que no fue supervisado, ni tuvo la vigilancia debida por parte de los mandos oficiales de la fuerzas armadas; ii) la existencia misma de la Base Militar de Las Delicias en una posición que no fue estudiada estratégicamente, ni se valoró adecuadamente las vías de escape y de penetración, lo que llevó a que en la mañana del 31 de agosto de 1996 se produjera la incursión completa de las fuerzas irregulares al interior de la Base; iii) el retardo injustificado e insuficiente del apoyo militar, pese a que en las proximidades se contaba con la Base de Tres Esquinas, los apoyos fluviales desde Puerto Leguízamo, el apoyo aéreo desde Apiay; iv) los fallos en el armamento y en la planeación de la infraestructura de la base necesaria para poder repeler y afrontar con garantías un ataque de los grupos subversivos; v) teniendo en cuenta que en la zona operaban los grupos subversivos, constituía un hecho notorio la posibilidad de ${ }^{113}$ Responsibility of States for Internationally Wrongful Acts, G.A. Res. 56/83, art. 2, U.N. GAOR, 56th
Sess., Supp. N ${ }^{\circ} 10$, U.N. Doc. A/RES/56/83 (enero 28, 2002). 
un ataque de los mismo, lo que representa una amenaza inminente, cierta e inevitable".

De las competencias funcionales, territoriales y materiales, como ejes de la configuración de la posición de garante, se puede extraer, entre otros, la trascendencia jurídica que tienen la apreciación de situación y las órdenes de operaciones, los contenidos de estos actos administrativos son vertebrales, sin duda, elaborados minuciosamente, son un binomio probatorio en las batallas jurídicas a que está enfrentada la Institución castrense, sin descartar los demás actos administrativos que en ella se elaboran. Del estudio general jurídico penal que se le realicen a estos documentos, los cuales están regulados por el Manual de Estado Mayor, se desciende a aspectos estructurales que cobran especial significación en materia penal a la hora de valorar las pruebas en un proceso.

Las apreciaciones de situación son un eje por el contenido que ordena el Manual de Estado Mayor, este dispone investigar y analizar aspectos que obligan conocimiento amplio y detallado de la jurisdicción asignada; algunos de los principales elementos constitutivos de la posición de garante, están inmersos en ese marco de las apreciaciones de situación, lo que obliga a explorar y actualizar la totalidad de la jurisdicción que se tiene bajo responsabilidad, igual, es necesario exponer en los documentos de manera concreta y amplia todos y cada uno de los pivotes que contiene el Manual de Estado Mayor, en cada una de las áreas, la situación de personal, el enemigo, las condiciones topográficas, las condiciones climatológicas, las necesidades, disponibilidades y limitaciones en cuanto al material, toda la información debe ser lo suficientemente actualizada y clara, que le permitan al operador de justicia formarse la idea real de la razón por la que se adelantó el comportamiento o se omitió.

La orden de operaciones es el acto administrativo que se concibe como producto de buena parte de los elementos estudiados en las apreciaciones de situación. Este documento, las órdenes de operaciones y, vale decir, las apreciaciones también han encontrado rutina en la elaboración de aspectos fundamentales como el mando y las comunicaciones, la incoherencia, en y entre la situación, la misión y la ejecución. Sin duda la suma de estas 
discordancias se traslada al llamado concepto de la operación, no menos, se divaga en el apoyo de fuegos y el empleo de la reserva (caso Las Delicias), así como en las tareas a las unidades en general, lo que no debe suceder si se tiene en cuenta que generalmente el resultado militar de las acciones o de las omisiones se relaciona con comportamientos directamente relacionados con los bienes jurídicos de la vida y la libertad de las personas, ya sea de las tropas, de la población civil o de los grupos al margen de la ley.

Desde la organización para el combate en las órdenes de operaciones se deben reflejar las unidades que se emplearán, coherentes con las estrictas misiones que se le imponen y las limitaciones en personal de que adolece la Unidad, pues ante la exigencia de empleo de la reserva para acudir a una acción de salvamento y omitir hacerlo por limitaciones de personal (y material), si estas limitaciones no han sido descritas en documento alguno, el incumplimiento al deber jurídico de actuar queda en el vacío y a la libre interpretación de los operadores jurídicos. En esta misma dirección, en lo relativo a los apoyos de fuego, es necesario reflejar las disponibilidades, tanto las reales como las potenciales, su verdadera capacidad y posibilidades de empleo, pues ante requerimientos de acciones de salvamento, aún de las mismas tropas ${ }^{114}$, son fundamentales para probar porque no se tenía el poder de desarrollar la acción. Para atribuir el mando y las comunicaciones es frecuente encontrar el término "omitido", lo cual deja en el limbo la responsabilidad jurídica de acción o de omisión, y permite las apreciaciones subjetivas y a veces bastante desapropiadas con la realidad de la actividad militar.

Para tratar de exponer un ejemplo: cuando la fuente de peligro o la creación de riesgo no permitido es ajeno a la Institución Militar ${ }^{115}$, el objetivo general del plan debe ser lo más explícito posible, pues será este el que se concibe para neutralizar ese riesgo (deber de seguridad en el tráfico y deber de salvamento). La jurisdicción que es afectada por el riesgo igualmente debe ser específica, es donde está el peligro o están siendo atacados los bienes jurídicos, y la misión asignada a las tropas debe establecer lo más concreto posible la

\footnotetext{
${ }^{114}$ Caso Las Delicias, Caso Patascoy, Caso El Porroso.

115 La degradación del orden público en determinada región del país o las amenazas directas sobre poblaciones, por parte de los grupos al margen de la ley.
} 
manera como se cumplirán, lo que en términos militares se denominan operaciones ofensivas de contraguerrilla ${ }^{116}$ y los recursos (capacidad material) puestos a disposición para ejecutarlas, los cual obligaría a las partes en un conflicto penal a informarse mejor del quehacer militar y evitar apreciaciones generales que no concretan la verdadera doctrina militar, y de contera hace daño en el ámbito penal. En este sentido es válido resaltar cómo una de las sentencias descarga la posición de garante, "no sólo por la razón de la fuente constitucional propia de su condición de militar y miembro de la Fuerza Pública, sino porque en la fecha de los acontecimientos ejercía el cargo de comandante de la Brigada $\mathrm{XXX}$, y que como tal le correspondía desarrollar «las operaciones ofensivas de contraguerrilla y control militar del área, en el área general de XXX»” (cfr. C.S.J. 25889 de 2007, Caso Mapiripan).

Para finalizar este capítulo, se puede ratificar que el artículo 217 de la Constitución, el artículo 25 de la Ley 599 de 2000 y el 27 de la Ley 1407 de 2010, son una verdadera tenaza jurídica, tenaza que es aún más fuerte en virtud a distintas manifestaciones jurisprudenciales $^{117}$. Sin duda son disposiciones constitucionales y legales insertas en la misión institucional, que obliga a los integrantes del estamento castrense a detenerse en su conocimiento, a realizar un despliegue de la cultura jurídica, a reaprender a preparar y elaborar los múltiples actos administrativos ${ }^{118}$ en todo su contexto, pues en su contenido se refleja lo atinente a las competencias funcionales, territoriales y materiales, lo relacionado a los límites de tiempo y de espacio, y lo relativo a la obediencia debida, aspectos todos directamente relacionados con la Omisión Impropia.

\footnotetext{
${ }^{116}$ Aunque parezca una exageración, la Institución debería mantener unos protocolos que le permitan la actualización, si no a diario, sí por lo menos cuando las circunstancias de tiempo, modo y lugar obliguen a cambiar el orden de prioridades impuesto en el plano en la orden de operaciones. Los objetivos de cada una de las operaciones ofensivas, aunque son coherentes en su secuencia, difieren en sus objetivos y no necesariamente se pueden marcar después de realizada la ocupación donde termina una y desde cuando inicia la otra.

${ }^{117}$ Sentencias C-358 de 1997 y SU-1184 de 2001, y Procesos 25536 de 2006 y 25889 de 2007.

${ }^{118}$ Los informes del Estado Mayor, las apreciaciones de situación, las órdenes de operaciones, los informes del cumplimiento de tales operaciones y en general los registros que se ocasionan con motivo del quehacer institucional que tiene que ver con el respeto a los Derechos Humanos y al Derecho Internacional Humanitario.
} 
El convenido de estos tres elementos que coadyuvan en la edificación de la posición de garante, a saber, las competencias funcionales, territoriales y materiales, están íntimamente ligadas con las normas que se deben cumplir relativas al Derecho Internacional Humanitario, particularmente con la protección a la población civil, a evitar los daños que a los bienes de esta se le puedan causar y al cumplimiento de las normas relativa a los combatientes sin armas, heridos y enfermos, como lo disponen los Convenios de Ginebra y el protocolo II referido especialmente al tipo de conflicto que enfrenta Colombia.

\section{La imputación objetiva y el delito de omisión impropia}

JAKOBS, entre otros autores, (puede estudiarse a ROXIN) trazó unas reglas, unas instituciones dogmáticas muy importantes, relacionadas con la imputación objetiva del comportamiento. Estas aparecen luego de hacer claridad respecto a los "deberes que comporta el tráfico", y las explica como deberes de aseguramiento y los deberes de salvamento, dos formas que siempre se originan de la configuración de la sociedad y de los roles que desempeñan los individuos, y en este tejido determina los comportamientos que la persona debe ejecutar o aquellos que debe evitar, teniendo el deber y pudiendo hacerlo. Es básico y cardinal apuntar lo que repetidamente expresa JAKOBS en este recuadro de la imputación objetiva del comportamiento, y la exposición de cada una de las figuras dogmáticas que expone: “(...) una sociedad sin riesgos no es posible (...)” (JAKOBS, 2001, p. 41). Puede afirmarse paralelamente que en las condiciones de inseguridad actual de Colombia es urgente buscar mejoramiento en la seguridad ciudadana, y que esta, sin asumir riesgos, no es posible, y esos riesgos los asume la fuerza militar en cumplimiento de la misión Constitucional.

Como quiera que los llamados deberes de aseguramiento y los deberes de salvamento abrazan los dos fundamentos por los que los miembros de la Institución Militar pueden ser garantes, es decir, la creación de riesgos para bienes jurídicos y el surgimiento de deberes

por la vinculación a la Institución (Sentencia SU-1184 de 2001), cimientos jurídicos que ya han sido debatidos en los estrados judiciales, es la razón por la cual se introducen las 
definiciones y algunas apreciaciones relativas a las cuatro instituciones dogmáticas referidas por JAKOBS: el riesgo permitido, el principio de confianza, la prohibición de regreso y la competencia de la víctima. Estas se tratarán de desarrollar más adelante, sin embargo, como primera ilustración de la interpretación de la dogmática, el derecho patrio, ya se manifestó en la Sentencia SU-1184 de 2001. MonTEALEGRE las expone abreviadamente en esta manifestación jurisprudencial, al buscar concretar el recorrido para imputar una conducta o un resultado, lo hizo así:

“(...) hay que delimitar (1) la posición de garantía que tiene el sujeto y si esta se origina en la creación de riesgos o en roles institucionales y consecuencialmente los deberes que surgen de estos. Hecho lo anterior, para hacer (2) el juicio de imputación, referencia los cuatro aspectos que permiten hacerlo: “(...) i) el riesgo permitido que autoriza la creación de peligros dentro de los límites que la sociedad va tolerando en virtud de las necesidades de desarrollo, ii) el principio de confianza, indispensable para que pueda darse una división del trabajo y que le permite al sujeto delegar ciertas tareas sobre la base de que los demás son personas autorresponsables que cumplirán con las expectativas que surgen de una determinada función, iii) las acciones a propio riesgo, en las cuales se imputa a la víctima las conductas que son producto de la violación de sus deberes de autoprotección y iv) la prohibición de regreso, según la cual, el favorecimiento de conductas dolosas o culposas por un tercero, no le son imputables a quien las hubiere facilitado dentro del riesgo permitido" (...) Finalmente y luego de demostrada la creación del riesgo desaprobado, es necesario que este (3) se realice, es decir se ejecute."

Se debe tener en cuenta en la imputación objetiva del comportamiento que el riesgo creado se ejecute en el resultado o dicho de otra manera debe haber una relación de causalidad entre el riesgo y el resultado; la jurisprudencia también resalta para el caso de los militares los deberes que le incumben precisamente por la posición de garante (cfr. SU 1184 de 2001.), y en general expone la importancia de precisar el momento en que ocurre la acción (omisión) para determinar el resultado de esta (cfr. 21241 de 2004.); estos aspectos tienen importancia entre otros, por la misma intervención de las demás figuras de la imputación objetiva a la hora de limitar la imputación penal por este sistema. 
De otro lado, es cardinal tener en cuenta, respecto a la imputación objetiva, que ésta, como sistema para limitar la imputación penal, abraza tanto a los delitos de acción como a los de omisión, explica la tentativa y la participación, igualmente el tipo objetivo doloso y culposo (LÓPEZ DÍAZ, 1998). En este sentido FORERo RAMÍREZ (2002), abordando el estudio del garante como autor y como partícipe, y analizando la injerencia dentro de los deberes de protección de determinados bienes jurídicos, trata el caso de "Lederspray""119, donde actuaban cuatro gerentes (a. química, b. técnica, adquisiciones, almacenamiento y transporte, c. administración financiera contable y personal, d. ventas), y analizando la responsabilidad penal de tales empleados se valoraron el caso fortuito, las lesiones personales culposas en comisión por omisión, las lesiones personales dolosas en comisión por omisión y las lesiones dolosas por acción. En este plano de distribución de responsabilidades de asesoramiento y toma de decisiones se quiere resaltar, como lo hace FORERO, las lesiones personales culposas en comisión por omisión y las lesiones personales dolosas en comisión por omisión.

Sobre estos mismos tópicos, la Corte Constitucional escribió, en la Sentencia SU-1184 de 2001:

En suma, desde el punto de vista estrictamente constitucional, resulta claro que las Fuerzas Militares ocupan una posición de garante para el respeto de los derechos fundamentales de los colombianos.

18. La existencia de esa posición de garante significa que el título de imputación se hace por el delito de lesa humanidad, o en general por las graves violaciones a los Derechos Humanos, sin importar la forma de intervención en el delito (autoría o participación), o el grado de ejecución del mismo (tentativa o consumación) o la atribución subjetiva (dolo o imprudencia). Las estructuras internas de la imputación no modifican la naturaleza del delito realizado; estas no cambian porque el interviniente (para el caso, quien omite) se limite a facilitar la comisión de un hecho principal, o porque no se alcance la consumación del hecho.

\footnotetext{
${ }^{119}$ El caso Lederspray lo resume FORERO RAMíREZ (pp. 72 y ss.).
} 
En efecto: i) el autor y el partícipe intervienen en un hecho único, porque el destinatario de la imputación es el colectivo que lo realiza; el cómplice y el determinador no realizan un injusto autónomo, porque el delito efectuado les pertenece a todos en conjunto. La diferencia entre autoría y participación es cuantitativa y no cualitativa; ii) en la tentativa por omisión -el garante retarda dolosamente la acción de salvamento o ésta no hubiera evitado la producción del resultado- el injusto del hecho sólo se diferencia de la consumación cuantitativamente - por el grado de desarrollo de la infracción de la normaporque también exige los elementos de la imputación del delito consumado: la creación del riesgo jurídicamente desaprobado y la realización del riesgo, y, iii) el conocimiento del riesgo (que sirve para deslindar el dolo de la imprudencia) no modifica la naturaleza de la conducta realizada (la grave violación a los Derechos Humanos). Es decir, en todos los casos mencionados hay unidad del título de imputación.

Lo anterior no implica desde luego que verificada la posición de garante se estructure inmediatamente la responsabilidad, porque ésta presupone la reunión de todos los elementos del delito, a saber: tipicidad, antijuridicidad y culpabilidad. Bien puede acontecer que el garante (a quien se le imputa un delito de lesa humanidad) no sea responsable penalmente por ausencia de dolo (no conocía el riesgo concreto para los bienes jurídicos) o imprudencia (el riesgo para los derechos fundamentales no le era cognoscible), o que exista un estado de necesidad justificante por colisión de deberes (frente a dos agresiones simultáneas a sectores de la población, sólo podía proteger una sola), etc.

Las anteriores citas se direccionan a prevenir las intervenciones que tienen los Estados Mayores y Planas Mayores en el cotidiano asesoramiento de planeamiento y ejecución de operaciones (acción), o en el asesoramiento de no realizarlas (omisión), por cuanto la responsabilidad por cualquiera de las dos vías, de acción o de omisión, en caso de ataques, peligros y/o lesiones de bienes jurídicos, superan la responsabilidad del asesoramiento operacional y traspasa al campo penal, sea por dolo o culpa, o en el marco de la participación, cuando resultan afectados bienes jurídicos, ya sea por la propia tropa o por un tercero, y no se acude a proteger los derechos de la población.

Es un imposible legal, un marco tan general, que un comandante asuma la responsabilidad por el accionar del numeroso personal a su mando. Las múltiples responsabilidades que se derivan de los actos que emanan de las competencias funcionales, materiales y territoriales deben girar en torno a las figuras como la creación de riesgos, el principio de confianza, la 
prohibición de regreso y la competencia de la víctima; sin embargo, si bien es cierto que existe dificultad para el control, las normas no eximen al Comandante de su responsabilidad de control por los actos de sus subalternos y menos en este ámbito de la imputación objetiva, donde el funcionalismo es protagonista y cuando este sistema ya se ha puesto en práctica en situaciones de conflicto interno y se ha relacionado con el Derecho Internacional Humanitario.

\subsection{Riesgo permitido}

Como premisa, en palabras de JAKOBS (2001, pp. 24 y ss.): “(...) para poder hacer uso de los bienes, es necesario poner en peligro estos u otros bienes". El mismo JAKOBS, dice que “(...) una sociedad sin riesgos no es posible y nadie se plantea renunciar seriamente a la sociedad (...)” (2001, p. 41). Con este sentido, y en en el cerco de los conceptos de seguridad y defensa como parte de la dinámica social el Estado, éste tiene el deber de cumplir con los objetivos constitucionales de protección de los bienes jurídicos de los asociados; entonces por voluntad del Estado surge la necesidad de que su instrumento militar para cumplir la misión asignada coloque en peligro bienes jurídicos de sus tropas, de la comunidad, e indudablemente de los grupos al margen de la ley.

Si bien, en la actividad social se corren múltiples casos de riesgos como de distintas maneras los señala la doctrina (JAKOBS, 2001, pp. 18 y ss.) entre tantos ejemplos: el tráfico rodado, el tráfico aéreo, la construcción de edificios, la actividad médica, las fábricas de armas y explosivos, para no citar más, estos son de mas fácil comprensión que los que habitualmente deben enfrentar los militares; la esencia la hace la particularidad de la guerra y sus distintas expresiones, el combate armado en sí con todas las habilidades de que se vale el ser humano para causarle daño al adversario, de estas situación, muy pocos pueden dar fe y por consiguiente muy pocos lo pueden entender.

En esta misma ruta Gómez Pavajeau (2005, p. 116), refiriéndose al tema de los deberes estándares y los deberes incrementados o intensificados, incluye en su estudio lo manifestado por la Corte Constitucional (Sentencia C-171 de 2004) en cuanto a la 
diferenciación entre los deberes del ciudadano del común y los que deben enfrentar los militares. El Tribunal Constitucional ha dicho que:

“(...) la Jurisdicción Penal Militar se diferencia de la jurisdicción ordinaria en que aquella asume la investigación y juzgamiento de delitos en los que se involucra el manejo de la fuerza, el sometimiento a reglas de conducta prescritas en el marco de una estricta línea de subordinación y el cumplimiento de deberes ajenos a los de la vida civil, los cuales, en muchos casos, exceden los compromisos asumidos por el ciudadano común."

EL MISMO GóMEZ (2005, pp. 227 y ss.), en el ejemplo que coloca entre los deberes que le conciernen a un agente del $\operatorname{DAS}^{120}$ y al militar ante el peligro para la vida en que se encuentra un secuestrado, escribió:

"Si se omite, resulta obvio que el tratamiento a uno y otro no puede ser el mismo, toda vez que el militar tiene indefectiblemente que actuar y por tanto sería autor por comisión por omisión. En cambio el agente del DAS, cuyo concurso también es necesario, pero sin que sus deberes sean tan intensos como los del primero, no puede negarse a hacerlo; de omitir, le sería imputable una complicidad si se verifica un acuerdo con los primeros para no actuar."

Esta sentencia seguidamente transcribe lo que el mismo Organismo ha expresado respecto a vertebral tema, ahora en cuanto a la trascendencia de la relación entre los comportamientos de los militares con relación a la aplicación de la fuerza, las normas de subordinación, las diferencias con aquellas que vive el ciudadano del común, y finalmente las limitaciones o dificultades de la justicia ordinaria para ejercitar el derecho positivo. Dijo la Corte:

"Este tratamiento particular, que se despliega tanto a nivel sustancial como procedimental, encuentra justificación en el hecho de que las conductas ilícitas sometidas a su consideración están estrechamente vinculadas con el manejo de la fuerza; y a que los sujetos activos que incurren en ellas están subordinados a reglas de comportamiento extrañas a las de la vida civil, todo lo cual marca una abierta incompatibilidad con el sistema punitivo a cargo de la jurisdicción ordinaria" (Sentencia C-676 de 2001)."

\footnotetext{
${ }^{120}$ Departamento Administrativo de Seguridad (D.A.S.), Institución que en el año 2011 fue eliminada de la estructura del Estado colombiano.
} 
La brecha funcional entre los militares y los que asume un ciudadano del común es muy amplia cuantitativa y cualitativamente, es amplia entre la misión que cumple un soldado regular y un soldado profesional, es amplia entre el soldado y el agente del DAS, y se distingue notoriamente entre la que cumple el soldado combatiente en cualquiera de sus rangos y el ciudadano del común que crea riesgos en cualquiera de las actividades, ya sea en el campo de la medicina, de la ingeniería, del tráfico rodado, etc.

De las afirmaciones jurisprudenciales se desprenden elementos que deben ser tenidos en cuenta en el panorama de los riesgos permitidos: por la situación de conflicto el militar está obligado a crear riesgos, los riesgos se crean contra bienes jurídicos de las tropas, de la población y de los mismos integrantes de los grupos al margen de la ley; las consecuencias de la guerra siempre son desastrosas, el uso de la fuerza tiene normas que lo limitan, si bien las reglas de comportamiento de los militares son extrañas a la vida civil, estas son rígidas en cuanto al respeto de los combatientes, de la población civil y de sus bienes entre otros, si bien la formación militar le hace exigencias superiores al soldado en comparación a los deberes de cualquier ciudadano, entre estas la mas álgida es precisamente la protección de los bienes jurídicos de la sociedad, sin embargo y a pesar de todo, no es posible que las Fuerzas Militares en el cumplimiento de sus funciones derivadas de la obligación constitucional dejen de correr riesgos, pero debe ocuparse de calcular esos riesgos, para lo cual es conveniente recordar que: "Cuando alguien va a desplegar una determinada acción, el primer deber que tiene es el de advertir el peligro para los bienes jurídicos; surge para él un deber de examen previo" (LóPEZ DíAZ, 1998, p. 117). La misma autora, citando a HANS-HEINRICH JESCHECK (Lehrbuch des Strafrechts), también afirma: "De este deber de examen previo surge el de valorar la propia capacidad del agente para realizar la acción; si alguien carece de la idoneidad suficiente para ejecutar una determinada actividad, su deber de cuidado es omitir la acción peligrosa” (pp. 523 y 524). En la misma obra, tratando el deber de advertir el peligro y los deberes de información, cita a RoxiN, así: “(...) quien algo no sabe, tiene que informarse, quien algo no puede, tiene que dejarlo (...)” (p. 118). 
Estas notas doctrinales trasladadas al quehacer militar y sumadas a las exigencias de los Convenios de Ginebra y a sus protocolos, comprometen la capacidad funcional del Comandante militar y de su Estado Mayor o Plana Mayor según la jerarquía de la Unidad, está igualmente comprometida la actualización y rigidez de los manuales militares para que con estas herramientas doctrinales, con la experiencia en su campo se apliquen todas las medidas preventivas que conduzcan a que los riesgos que se vayan a crear estén en ese espacio tan difícil de cercar como lo indican los denominados riesgos permitidos. ¿Pero cuáles son los riesgos que especialmente deben prever el Comandante y su Plana Mayor? Indudablemente que giran en torno a la protección de los bienes jurídicos de las tropas, de la población civil y de los mismos integrantes de las organizaciones al margen de la ley, para lo cual es absolutamente necesario desarrollar correctamente las exigencias normativas y conceptuales del objetivo militar y tener en cuenta los principios de necesidad, proporcionalidad, distinción y humanidad. Para los tres potenciales receptores de los riesgos a sus bienes jurídicos, existen distintos factores que facilitan o limitan su protección, se parte de las informaciones que se tiene y de la necesidad militar de realizar la operación, lo que conduce al análisis de entre otros, la ubicación del enemigo respecto de la población y las incidencias que puede tener la operación sobre esta respecto de los resultados que se buscan.

Como quiera que la renombrada Sentencia SU-1184 de 2001 expresó que los miembros de la Institución Militar pueden ser garantes ante la creación de riesgos para bienes jurídicos y el surgimiento de deberes por la vinculación a la Institución, se tratará de establecer solo algunas de las múltiples actividades que ejecutan el Ejército, la Fuerza Aérea y la Armada Nacional en actividades de entrenamiento y combate, las cuales son parte de los deberes de seguridad en el tráfico y de los deberes de salvamento, aspectos precisados por el Tribunal Penal.

De conformidad a la sentencia en mención, el deber de seguridad en el tráfico tiene directa relación con el estricto control que debe establecer y ejecutar el superior para realizar un 
estricto control sobre los subalternos, y los deberes de salvamento se fundamenta y se deriva de la competencia institucional del Estado, la que, ante la imposibilidad de que el Estado responda, la responsabilidad recae en el militar que cumpla una función y ostente a la vez la posición de garante (competencias funcional, territorial y material). De estos ingredientes jurisprudenciales es que se deduce la responsabilidad de los integrantes de la Institución Castrense, de defender la población que se encuentre amenazada por los grupos al margen de la ley, y de no hacerlo, estando en capacidad, estaría precisamente omitiendo esos deberes de salvamento. En la ruta de los deberes de salvamento y de los mismos deberes de seguridad en el tráfico, desde el planeamiento hasta la ejecución de las operaciones militares ofensivas que se planean y desarrollan en dirección a la protección de los bienes jurídicos de las tropas, de la población civil y de los integrantes de las organizaciones al margen de la ley, tienen en el contexto del Derecho internacional Humanitario, algunos interrogantes que tienen relación directa con el derecho penal:

a) ¿Cómo se equilibra el riesgo que se presenta para los bienes jurídicos de la población que es atacada por un grupo al margen de la ley, frente al riesgo jurídico que se crea en relación con la tropa que debe salir a su salvamento?

b) ¿Predomina a toda costa el ritual del juramento a la bandera de "llegado el caso morir por defenderte"?

c) Ante el posible ataque a una población, ¿cuál es la disposición que rige para establecer el riesgo permitido ante las múltiples alertas tempranas, las tareas en ejecución y las limitaciones de la unidad comprometida?

d) ¿Cuál es el poder de combate en cuanto a la clase de armas, que le permite la jurisdicción ordinaria utilizar al soldado para atacar al enemigo y defenderse a la vez? 
Lo anterior, porque, en principio, por estar de por medio precisamente el bien jurídico de la vida y la misma libertad, y ya que su protección es gravitante en el marco de la misión constitucional, es importante observar que también algunos militares han sido procesados por la muerte de la tropa que ha asistido al amparo de bienes jurídicos, acusados ya sea de omisión propia como prevaricato por omisión u Omisión Impropia, y en otras ocasiones los comandantes militares han sido investigados por la supuesta falta de control de los subalternos (deber de control en el tráfico), en otras han tenido que asumir el riesgo de omitir una operación militar (deber de salvamento), estas últimas seguramente basadas en las conclusiones de las apreciaciones de situación que hacen sus miembros de Estado Mayor o Plana mayor, donde quizá surgen las deficiencias de las capacidades materiales y/o funcionales que limitan o impiden la operación militar (personal y material especializado, factores atmosféricos, incrementos del riesgo, límites de espacio, deficiencia en la inteligencia, etc.).

En esta dirección de los riesgos permitidos también tienen protagonismo las autoridades civiles $^{121}$, la Policía ${ }^{122}$ y los mismos medios de comunicación ${ }^{123}$, pues de estas autoridades provienen regularmente las denominadas alertas tempranas (las informaciones) sobre el peligro de ataquen a bienes jurídicos y corresponde entonces por lo general a las autoridades militares decidir las acciones y las omisiones a seguir, esta es la razón para que los protocolos sean motivo de permanente revisión y actualización para evitar que los riesgos (riesgo permitido) que se dejen al descubierto generen acciones penales.

Ante todas las incertidumbres de la guerra y las dificultades que afrontan los integrantes de las Fuerzas Militares en el campo penal, es preciso acudir a la consulta, estudio y práctica de los instrumentos legales para crear pautas y mejorar los protocolos existentes que les permita asegurarse jurídicamente, cuando del control de los subalternos se trata (seguridad

\footnotetext{
${ }^{121}$ Gobernadores, Alcaldes y Personeros.

${ }^{122}$ En el caso Jamundi, las alertas no fluyeron con suficiente velocidad y precisión. Hechos ocurridos el 22 de mayo de 1997 en el área general de Potrerito, del municipio de Jamundí (Valle del Cauca), donde resultaron muertos 10 policías y un particular

${ }^{123}$ Ya se hizo referencia también a las Noticias Caracol del 10 de septiembre de 2010 en horario de las 7:00 p.m.
} 
en el tráfico) o cuando deban omitir la ejecución de una operación militar que se enmarca en los riesgos permitidos (deberes de salvamento), que se tenía el deber, pero que los estudios de Estado Mayor o de Plana Mayor indican las limitaciones o imposibilidad de desarrollar. Como un todo jurídicamente, es entonces, el deber de "examen previo" al que se refiere LóPEZ (1998), y que desarrollando este tema, coloca como ejemplo el arquitecto que no tiene la capacidad técnica para dirigir una compleja construcción y que por no corresponder a su especialidad no debe realizarla, es un ejemplo demasiado sencillo, frente a las exigencias y a las circunstancias de tiempo, modo y lugar en que se exige al combatiente militar en cumplimiento de operaciones. Indudablemente que la preparación del arquitecto y las dificultades que pueda tener en el desarrollo de su obra maestra es incomparable a la actividad que el miembro de la Institución Militar cumple cuando sale en defensa de bienes jurídicos, por ejemplo: ante el ataque a una población o la emboscada a otra patrulla, se enfrenta a peligros para bienes jurídicos en las tres líneas (los propios, los de la población civil y los del grupo al margen de la ley), amén de los ataques con las armas mortíferas de los grupos al margen de la ley, al punto que sus decisiones, a veces acertadas en el campo de combate, luego ex post, son cuestionadas, investigadas y atacadas con simples apreciaciones sin argumentación fundada en la realidad de los hechos y tampoco en las fuentes del derecho, es decir en contravía a los derroteros de la misma Corte Suprema, (Proceso No 21241 de 2004) la que manifestó:

"La violación al deber de cuidado objetivo se evalúa siempre dentro de un ámbito situacional determinado, es decir, por medio de un juicio de la conducta humana en el contexto de relación en el cual se desempeñó el actor, y no en el aislamiento de la fealdad de lo que éste hizo o dejó de hacer. En orden a examinar la violación del deber de cuidado objetivo, rige la regla de confianza, elaboración doctrinaria que parte del hecho de la intersubjetividad permanente del ser humano, razón por la cual, quien participa de una actividad riesgosa, compleja o delicada, en la medida en que actúa diligente y cuidadosamente tiene derecho a confiar en que los demás partícipes harán lo propio.” 


\subsection{Principio de confianza}

Escribe el profesor JAKOSB: "Cuando el comportamiento de los seres humanos se entrelaza, no forma parte del rol del ciudadano controlar de manera permanente a todos los demás, de otro modo, no sería posible la división de trabajo" (2001, p. 28).

RAÚL ZAFFARONI, dice:

"Toda vez que se trata de actividades en las que rige una división de trabajo o de la tarea, el criterio que se aplica para determinar la medida de la creación de un peligro prohibido es, en estos casos, el principio de confianza según el cual no viola el deber de cuidado la acción del que confía en que el otro se comportara correctamente mientras no tenga razón suficiente para dudar o creer lo contrario. El límite del principio de confianza se halla, en primer lugar, en el propio deber de observación: es violatorio del deber de cuidado mantener la confianza, cuando, en el propio ámbito de observación, han entrado indicios de que el otro no se comportaba conforme a lo esperado: el cirujano que observa cómo el instrumentista quirúrgico le pasa un bisturí que no se encuentra en debido estado de asepsia, no puede ampararse luego en el principio de confianza frente a la lesión que se produce por el uso de dicho elemento (2006, p. 436)."

ReYes AlvarAdo (2005, p. 148), en su estudio sobre la Imputación objetiva, coloca variados análisis respecto del principio de confianza, lo que contribuye al esclarecimiento y buena práctica en el quehacer jurídico. Escribe el autor:

"B. El principio de confianza. Bajo ideales circunstancias, una comunidad social deberá funcionar de manera tal que sus integrantes, sin excepción, llenarán las expectativas de comportamiento que de ellos se esperan, razón por la cual cuando determinadas conductas se apartan de los criterios trazados por la sociedad se recurre al empleo de mecanismos que, como el derecho, tienen la pretensión de reconducir la actividad de las personas en busca de ese ideal de convivencia social. (...) Como consecuencia de ese consenso que teóricamente debería estar detrás de las directrices de comportamiento social, emerge la necesidad de que cada sujeto pueda organizar su actividad sobre el supuesto de que las demás personas se comportarán también de manera reglamentaria, a pasar de que la experiencia enseñe que ello no siempre ocurre así, a partir de esos supuestos la doctrina y la jurisprudencia reconocen la existencia de un principio de confianza que encierra 
justamente la facultad de asumir como regla general de comportamiento que los ciudadanos se conducen conforme a las previsiones sociales de conducta.

FORERO (2002, p. 151), al analizar el principio de confianza, inicia así: "Este principio parte de la base en que una persona tiene derecho a confiar en que otra actuará conforme a derecho o cumpliendo su función (...)".

Y ClAUdia LóPEZ (1998, pp. 133 y 134), tratando el mismo tema, describe:

"En virtud del principio de confianza, en la vida de relación se tiene derecho a esperar de los demás un comportamiento reglamentario; nadie necesita planificar su actividad partiendo del punto de vista de que los otros violarán las expectativas de conducta que nacen de su rol. (...)".

La Corte Penal (Procesos N 22354 de 2006 y 14124 de 2002), en lo que tiene que ver con el principio de confianza, resolviendo el recurso de casación interpuesto por la apoderada de parte civil contra una sentencia dictada por el Tribunal Superior Militar, por el delito de peculado por apropiación, reitera la siguiente posición del Tribunal sobre el principio de confianza, haciendo énfasis en el ámbito de la administración pública y los límites en su aplicación, resalta que en anterior proceso ya se había manifestado de igual manera, y declaró:

"Es cierto que una de las características del mundo contemporáneo es la complejidad de las relaciones sociales y, en materia de producción de bienes o servicios, la especialización en las diferentes tareas que componen el proceso de trabajo. Esta implica la división de funciones entre los miembros del equipo de trabajo y por lo tanto un actuar conjunto para el logro de las finalidades corporativas. Como no siempre es controlable todo el proceso por una sola persona y en consideración a que exigir a cada individuo que revise el trabajo ajeno haría ineficaz la división del trabajo, es claro que uno de los soportes de las actividades de equipo con especialización funcional es la confianza entre sus miembros. Esta, cuando ha precedido una adecuada selección del personal, impide que un defecto en el proceso de trabajo con implicaciones penales se le pueda atribuir a quien lo lidera, a condición naturalmente de que no lo haya provocado dolosamente o propiciado por ausencia o deficiencia de la vigilancia debida." 
Advierte el Tribunal Penal (Proceso $N^{\circ} 22354$ de 2006) que:

“(...) además, porque en la división vertical del trabajo siempre hay una o más personas dentro de cuyo ámbito de competencia está vigilar que los «subordinados» cumplan a cabalidad las instrucciones dadas, rol cuyo abandono comporta, en este caso, la configuración del tipo de peculado por apropiación en la medida que produjo resultados patrimoniales perjudiciales para la Armada Nacional."

En otra de las expresiones la Corte Penal (Proceso $N^{\circ} 24031$ de 2006), absolviendo un recurso de apelación por peculado culposo, se refiere a la definición y desarrollo del principio de confianza, así:

"De acuerdo con este principio, no se imputan objetivamente los resultados producidos por quien ha obrado confiando en que otros se mantienen dentro de los límites del peligro permitido.

Se enuncia diciendo que toda persona, en el diario discurrir, puede creer que las demás actúan dentro de las normas y de acuerdo con los requerimientos socioculturales dominantes, a menos que "existan datos que hagan pensar lo contrario".

Este postulado, ab initio admisible, no es absoluto, pues para eventos como el ahora examinado, varios motivos excluyen su aplicación. Por ejemplo los siguientes:

"Uno. Porque la ley puede exigir a quien confía en otro que lo haga bajo su responsabilidad, cumpliendo con un cuidado especial, evento en el cual no se puede escudar en el axioma mencionado.

Dos. En la división vertical del trabajo, porque siempre hay una o más personas que se encargan de vigilar que los "subordinados" hayan comprendido a cabalidad las instrucciones dadas; en ese sentido, el ámbito de competencia de estas personas que se encargan de vigilar las labores de terceras personas son garantes a efectos de que estas se desempeñen correctamente.

Tres. Si uno de los requisitos para esquivar la responsabilidad con fundamento en el principio de confianza es el de que quien lo aduzca se haya comportado correctamente, cuando se infringe el derecho por incumplimiento de los deberes que este impone, no es posible acudir a ese postulado. (...). 
Cuatro. Por último, recuérdese que tampoco puede ser exonerado de imputación con fundamento en el principio de confianza, quien divide el trabajo con personal sin suficiente cualificación profesional para desplegar determinadas tareas, pues en este supuesto se requiere de su parte aún más vigilancia, custodia y supervisión estricta."

Pero si bien una sociedad sin riesgos no es posible, y el principio de confianza, igual, está presente en gran parte de esa dinámica social, hay elementos dentro de este principio que se exponen como excepciones a la regla general. La Corte Suprema, en el caso de un conductor de servicio público (tenía posición de garante) que subió a su vehículo a un hombre mayor de edad embriagado y aquel no cumplió con las normas de tránsito, (no cerrar la puerta, entre otros) no se le concedió el beneficio de la aplicación del principio de confianza, el Tribunal Penal (Procesos N 16636 de 2003 y 22511 de 2005), se expresó así:

“e) Una circunstancia que exime de la imputación jurídica u objetiva por disolución de la actividad peligrosa o por desaparición de la superación del riesgo permitido, es el denominado principio de confianza, en virtud del cual el hombre normal espera que los demás actúen de acuerdo con los mandatos legales, dentro de su competencia.

Seguramente, en ese principio tenía fe el finado y probablemente el señor XXX también esperaba comportamiento correcto de aquél, es decir, del usuario.

Sin embargo, el principio de confianza tiene limitaciones como ocurre en eventos como el ahora analizado.

Al principio de confianza se opone, y prima sobre él, el principio de defensa, también conocido como principio de seguridad.

Este postulado significa que el hombre medio debe prever que si bien en la actividad diaria está sujeto al principio de confianza, determinadas personas pueden obrar en contra de los reglamentos, como sucede con los niños, los infantes, los minusválidos, los enfermos y, por supuesto, los ancianos (...)”.

Las anteriores referencias doctrinales y jurisprudenciales, sirven para resaltar el contexto de la figura para que se observe como en la práctica militar existen casos donde se vulnera el principio de confianza y los resultados son extremadamente graves. En el caso San José de Apartadó se entiende que algunos subalternos realizaban unas actividades no ordenadas y 
en los reportes desinformaban al superior sobre su verdadera ubicación, ${ }^{124}$ creando una verdadera confusión horizontal y vertical para la toma de decisiones. En ese orden, puede afirmarse que el principio de confianza tiene relación directa con el contenido del concepto del honor militar, en su texto se evidencia principios y valores que soportan necesarias cualidades para la práctica del principio de confianza. Dice:

“(...) Uno de sus pilares fundamentales es el honor militar, el cual es el conjunto de cualidades morales y profesionales que sustentan las virtudes castrenses del valor, lealtad, rectitud y decoro que colocan al militar en condiciones de aprecio dentro de la institución y la sociedad a que pertenece (Reglamento de Régimen Disciplinario, Ley 836 de 2003, artículo 24)."

En este punto es relevante el principio de confianza en la dinámica del quehacer militar, y en particular en las operaciones militares, pues desde las fases de planeamiento de operaciones aplica este principio, de una parte, con el manejo de la información creíble disponible, y de otra con la ejecución de las acciones militares planeadas, siempre creyendo que todos y cada uno están dentro de ese marco del principio de confianza acordes con las exigencias institucionales. Como poca jurisprudencia hay en concreto sobre este tema, se acude a la siguiente posición de la Corte Penal en un caso de contratación administrativa. Señaló el Tribunal:

"Tal principio de confianza opera en una comunidad determinada de interrelación, cuando quien realiza el riesgo tolerado conforme a las normas que disciplinan la actividad correspondiente puede esperar que quienes intervienen en el tráfico jurídico también observen a su vez las reglas pertinentes, de modo que no se le puede imputar un resultado antijurídico en desarrollo de la actividad riesgosa permitida conforme al deber de atención, si en ésta interfiere un tercero que desatiende la norma de cuidado que le es exigible, o si a pesar de no atender la norma de cuidado esta desatención no fue determinante en tal producto, sino la injerencia, dolosa o culposa, de ese tercero.

La determinación de la efectividad del principio de confianza en un ámbito de interrelación está guiada por la apreciación racional de las pautas que la experiencia brinda o de las concretas condiciones en que se desenvuelve una

\footnotetext{
${ }^{124}$ Así se deriva del fallo del Juzgado Segundo Especializado de Antioquia, en la Sentencia de fecha 04 agosto de 2010, dentro del proceso P 200900015.
} 
actividad $\mathrm{u}$ organización determinada, porque son elementos que posibilitan señalar si una persona, al satisfacer las reglas de comportamiento que de ella se esperan, está habilitada para confiar en que el dolo o la culpa de los demás que interactúan en el tráfico jurídico no la van a afectar"( Proceso $\mathrm{N}^{\circ} 22511$ de 2005.)

En este contenido de la jurisprudencia y la doctrina, permite trasladar a los destinatarios un marco general sobre el principio de confianza como aspecto medular en la misión constitucional de amparar los bienes jurídicos de la vida y la libertad. La aplicabilidad de este principio de confianza en el escenario militar siempre estará vigente, tanto en sentido horizontal como vertical, y no solo al interior de cada una de las Fuerzas Militares, sino en las coordinaciones que se realicen entre ellas y sin interrumpir el mandato constitucional, también es aplicable el principio de confianza entre las Fuerzas Militares y la autoridad civil, local, regional y nacional.

En este orden, en las Instituciones Castrenses la práctica del principio de confianza se irradia de manera amplia y notoria en los deberes de seguridad en el tráfico y en los deberes de salvamento. En una y otra circunstancia la trascendencia de la práctica de las imposiciones que regula el principio son medulares, en virtud precisamente de que se trata de actuar u omitir en la protección de los Derechos Humanos y del Derecho Internacional Humanitario; se resalta aquí que, dentro del concepto de la división de trabajo y la responsabilidad de los intervinientes en cumplir los requerimientos del mandato, en el campo militar surgen serias dificultades que se materializan en las circunstancias de tiempo, modo y lugar, debido a la exclusividad de la dinámica en la ejecución de las tareas (hacer o no hacer teniendo el deber) de los sujetos activos (las tropas) frente a la de los posibles sujetos pasivos (el enemigo). Es decir, el superior jerárquico confía en que el (los) subalterno (s) actuará (n) acorde a la orden emitida, que conoce la doctrina (reglamentos y manuales), que tiene el entrenamiento y la pericia para su desempeño; en otros términos, que sabe, conoce y coloca en práctica sus deberes funcionales. En contravía, el subalterno confía en que su superior ordena lo legal y ha evaluado los riesgos que demanda la acción o la omisión. 
Un comandante militar puede omitir ejecutar una acción (deber de salvamento) por limitación en sus capacidades materiales de frente al análisis que realice en el instante de la valoración de potenciales $^{125}$ (capacidad tropa-enemigo) que solo él conoce y está en la obligación de decidir, situación que no puede dejarse al azar, debe quedar en el menor tiempo posible registrada mas allá de las mismas instancias militares, pues jurisprudencia y doctrina coinciden en la mayor exigencia funcional que se le hace a los militares con relación al ciudadano del común ${ }^{126}$. De igual manera, el principio de confianza tiene que ver con la legalidad, lo que se ordena y lo que se obedece deben tener directa relación con la definición militar que se le da a estos dos términos. El comandante ordena lo legal y el subalterno obedece esa orden; el comandante ordena lo ilegal y el subalterno no está en la obligación de cumplirla. Uno y otro, comandante y subalterno, siempre ejercerán en el marco de la legalidad.

Quien ordena una operación militar está en el derecho de confiar que sus subalternos la ejecutarán dentro del marco legal y dirigida únicamente al fin con el cual se planeó, y se ordena la ejecución; de igual manera el subalterno que se dispone a cumplir una orden militar, ya sea dentro del cuartel o en el marco de una operación militar, está en el derecho de confiar que lo ordenado por su superior se rige por la ley. En este marco unos y otros, es decir comandantes y subalternos, están en la obligación de hacer su propia valoración, ya sea respecto de lo ordenado o de lo que se debe cumplir, así que si no existe la seguridad plena de que lo que se está ordenando, o que de lo que se está ejecutando está de acuerdo a la ley, deben abstenerse de ordenarlo o de cumplirlo, esto en el sentido vertical. Horizontalmente, se debe saber que antes de que un comandante decida ordenar una operación militar, se suceden unos planteamientos y acciones de este y de su Estado Mayor, que además se materializan en documentos ${ }^{127}$ en los cuales se inicia a reflejar el principio de confianza en la cadena de mando. Se sucede en la correcta información que los miembros del

\footnotetext{
${ }^{125} \mathrm{El}$ operador de justicia en este tema puede acudir a los manuales militares, donde encuentra suficiente información al respecto. Aspectos tangibles e intangibles: hombres, entrenamiento, armas, dificultades topográficas, de tiempo atmosférico, de medios materiales, etc.

${ }^{126}$ Puede confrontarse Gómez PAVAJEAu (2005, p. 116.) y la Sentencia C-171 de 2004, citada por el autor.

${ }^{127}$ Desde la guía de planeamiento las apreciaciones de situación, las órdenes de operaciones, los anexos a ésta y todos aquellos que tengan que ver con la decisión del Comandante.
} 
Estado Mayor aportan al Comandante para que éste tome la decisión correcta, no solo en el sentido operacional, sino legal, so pena de incurrir en omisiones por causa de deficiencias en la información y asesoría que lleguen a trascender al derecho penal.

\subsection{Prohibición de regreso}

Escribe el profesor JАKOBS:

"El carácter conjunto de un comportamiento no puede imponerse de modo unilateral-arbitrario. Por tanto, quien asume con otro un vínculo que de modo estereotipado es inocuo, no quebranta su rol como ciudadano aunque el otro incardine dicho vínculo en una organización no permitida. Por consiguiente, existe una prohibición de regreso cuyo contenido es que un comportamiento que de modo estereotipado es inocuo no constituye participación en una organización no permitida (2001, p. 30)".

Para LóPEZ la prohibición de regreso, “(...) en la actualidad se trata de un ámbito de colaboración dolosa o culposa de un tercero en la realización del tipo penal, sin que exista responsabilidad para ese «partícipe»» (1998, p. 130).

La Corte Constitucional, respecto a este principio, escribió en la Sentencia SU-1184 de 2001: "La prohibición de regreso, según la cual, el favorecimiento de conductas dolosas o culposas por un tercero, no le son imputables a quien las hubiere facilitado dentro del riesgo permitido".

La Corte Suprema (Proceso $N^{\circ} 12742$ de 2003) sobre el particular, también escribió en abril de 2003:

"La teoría de la prohibición de regreso, de larga data -hecha en sus inicios para corregir la teoría de la equivalencia de las condiciones en materia de causalidad material-, afirma que cuando una persona realiza una conducta culposa, irrelevante o inocua para el derecho penal, y con ella facilita, propicia o estimula la comisión de un delito doloso o culposo por parte de otra, no le es imputable el comportamiento criminoso de esta última, excepto si tiene posición de garante, 
excede los límites del riesgo permitido y conoce la posibilidad de comisión de delito doloso o culposo por parte de la otra."

En este campo, y teniendo en cuenta distintas situaciones del conflicto, se presentan sin duda eventos en los que la tropa retiene personas conforme a lo normado en el artículo 28 de la Constitución Nacional, y cumplidos los términos se dejan en libertad. El comportamiento reviste connotación penal cuando los individuos, después de colocados en libertad, sufren atentados contra su vida e integridad, y más delicado cuando, al colocarlos en libertad no se cumplieron protocolos de rigor, como las actas de buen trato, la entrega con acta a la autoridad civil competente, y en los casos de que no haya en el sector autoridad civil debe buscarse el apoyo de testigos.

Como el principio de confianza, éste, el de la prohibición de regreso, tampoco es absoluto, pues existe variedad de casos para análisis. Puede que quien creó el riesgo no tuvo nada que ver en la realización de este, pero igual no puede haber ningún nexo causal entre el creador del riesgo y quien lo realizó. De ser así, se estaría, tal vez, en las figuras de la coautoría o la participación.

\subsection{Competencia de la víctima}

Dentro de los principios de JAKOBS está la actuación a riesgo propio de la víctima o competencia de la víctima. Mediante esta institución JAKOBS (2001, p. 32) propone tener en cuenta la intervención de la víctima en el suceso. En este punto, la teoría de la imputación objetiva implica la introducción de elementos valorativos que determinan cuáles son los límites de la libertad de actuación, que envuelve, en este sentido, el establecimiento de esferas de responsabilidad. Escribió que:

“(...) puede que la configuración de un contacto social competa no solo al autor, sino también a la víctima, incluso en un doble sentido: puede que el propio comportamiento de la víctima fundamente que se le impute la consecuencia lesiva, y puede que la víctima se encuentre en la desgraciada situación de hallarse en esa 
posición por obra del destino, por infortunio. Existe, por tanto, una competencia de la víctima."

La misma Sentencia SU-1184 de 2001 manifiesta que en las acciones a propio riesgo, “(...) se le imputa a la víctima las conductas que son producto de la violación de sus deberes de autoprotección".

La Corte Suprema, en la ya referenciada Sentencia $N^{\circ} 22511$ de 2005, relativa a un homicidio culposo en accidente de tránsito, expresó con relación al comportamiento de la víctima:

“(...) 4. Finalmente, el actor busca negar la imputación al conductor afirmando que el resultado lesivo fue producto de la autopuesta en peligro emanada de la conducta de la propia víctima".

Respóndese:

a) Es sabido que el comportamiento de la víctima, bajo ciertas condiciones, puede eventualmente modificar y hasta excluir la imputación jurídica al actor.

b) Para que la acción a propio riesgo o autopuesta en peligro de la víctima excluya o modifique la imputación al autor o partícipe es necesario que ella:

Uno. En el caso concreto, tenga el poder de decidir si asume el riesgo y el resultado.

Dos. Que sea autorresponsable, es decir, que conozca o tenga posibilidad de conocer el peligro que afronta con su actuar. Con otras palabras, que la acompañe capacidad para discernir sobre el alcance del riesgo.

Tres. Que el actor no tenga posición de garante respecto de ella.

Si se vuelven a mirar los folios, concretamente aquellos que constituyen la prueba, la conclusión es fácil: don..., dado su estado de ebriedad, el sueño que tenía según un testigo, y su edad, sentado en el estribo del automotor, no contaba con la posibilidad de decidir si asumía o no riesgos; por las mismas razones, no tenía suficiencia para determinar si con su conducta se colocaba en situación de riesgo; y, por último, que podría ser lo primero y único, el conductor tenía posición de garante, como se dijo atrás, respecto del ofendido (...)."

A manera de ejemplo: 
Un señor Comandante de División tiene en agregación una Unidad de Fuerzas Especiales (18 hombres); le entrega esta unidad especial a un Comandante de Brigada Móvil que está también bajo su órdenes, a su vez, se advierte que esta Brigada Móvil ingresó a la jurisdicción territorial de otra Brigada de la misma División. Para ejecutar la operación militar que ordenó el Comandante de la División, éste dispuso además del apoyo de dos Destacamentos Aéreos y el apoyo de Fiscales (5) de la Jurisdicción y un grupo de agentes (8) del Cuerpo Técnico de Investigaciones (C.T.I.).

En el curso de la operación militar el Comandante de la Brigada Móvil decide trasladar algunas personas con antecedentes penales, y otras más sin antecedentes judiciales, pero en virtud al hallazgo en la zona de material explosivo e insumos propios del narcotráfico los particulares pernoctaron una noche en el Puesto de Mando de la Brigada Móvil bajo la responsabilidad del grupo de Fuerzas Especiales. Al día siguiente fueron entregados con acta (y fotografías) a la autoridad civil del municipio donde se ejecutó la operación militar, autoridad que estaba representada por el Alcalde y el Personero. Éstos prácticamente de inmediato dejan en libertad a todos los campesinos. Dentro de las veinticuatro horas siguientes siete de ellos, cuando hacían desplazamientos por su región fueron desaparecidos, y enterados los coterráneos se produce el desplazamiento de algunas familias de la región.

Luego de los informes de rigor de las autoridades civiles y de las investigaciones previas al Comandante de la Brigada Móvil, y al Comandante del grupo de Fuerzas Especiales, les imputan privación ilegal de la libertad, homicidio agravado, desaparición forzada y desplazamiento forzado.

A primera vista en este ejemplo se advierten, de una parte, la problemática de la posición de garante, y de otra, las instituciones dogmáticas señaladas por JAKOBS en el marco de la imputación objetiva. En cuanto a lo primero, se esbozará lo pertinente a las competencias funcionales, territoriales y materiales, y en cuanto a lo segundo se tendrán en cuenta las 
reglas relativas a las figuras de la creación de riesgos, el principio de confianza, la prohibición de regreso y la competencia de la víctima.

En este orden, y en cuanto a las competencias, se debe observar cómo éstas se entrecruzan en la dinámica de las operaciones que desarrollan los militares, y mucho más cuando como, en este caso, se tienen unos componentes especiales como la presencia de otros organismos del Estado y personal y material especial, representado en un destacamento aéreo (helicópteros de combate y para transporte de personal). Esta situación hace que el ordenador de la operación esté en permanente control de lo ordenado, en virtud precisamente de que es su capacidad funcional la que tiene el poder dispositivo de ordenar para cumplir el deber jurídico propuesto (objetivo de la operación), capacidad que la podría delegar hasta en un Comandante de Brigada, entre otros, precisamente por la jerarquía de los mismos acompañantes de la acción militar. Como se puede proponer, con lo reseñado están involucradas, además de las competencias funcionales, las competencias materiales y territoriales. En el escenario del ejemplo propuesto hay retenidos ${ }^{128}$, de los cuales temporalmente tiene la posición de garante un oficial subalterno, mientras los transporta y mientras pernoctan bajo su responsabilidad en el Puesto de Mando. La misma posición la tenía el Comandante de la Brigada donde pasaron la noche los retenidos. Se involucran en el evento el alcalde y el personero de la localidad, cuando éstos reciben formalmente y con acta al personal que ha sido puesto a su disposición con acta de entrega para que conste su estado de salud y puedan gozar de la libertad, como en efecto lo hace la autoridad civil en cumplimiento de sus obligaciones constitucionales.

Respecto a las instituciones dogmáticas de la imputación objetiva del comportamiento se debate la figura de la creación de riesgos, aparentemente por la retención administrativa de las personas. Se discute la aplicación del principio de confianza, éste, desde los momentos de la captura, el tiempo que los tuvo un oficial subalterno bajo su responsabilidad, hasta el mismo momento en que se entregan las personas a las autoridades civiles competentes, como quiera que una vez puestos en libertad los ciudadanos, éstos, en uso de su derecho a

\footnotetext{
${ }^{128}$ Acorde al artículo 28 de la Constitución Nacional.
} 
la libre locomoción (competencia de la víctima) tomaron caminos diferentes y algunos de ellos mueren. Se aplicaría la prohibición de regreso, además porque hubo un tercero sin ninguna relación con los militares y que por tanto se desconoce, y fue quien consumó los tipos penales de homicidio y desaparición.

Otro Ejemplo: En la jurisdicción de una División del Ejército se vive una situación tensa en virtud de los comicios electorales. La variedad de amenazas cobijan toma de poblaciones, retenes guerrilleros, asalto a bases militares, emboscadas a patrullas, acciones terroristas con explosivos, alteración del sistema de alumbrado público, voladura de puentes, entre otros, por lo que en la rutina de las autoridades civiles y los mandos militares disponen la ejecución de un Consejo de Seguridad, el cual se lleva a cabo, y entre la asignación de jurisdicciones y misiones se dispone la coordinación entre las tropas para no causar enfrentamientos entre las mismas.

A pesar de estas coordinaciones y mandatos una patrulla penetra a la jurisdicción donde se encontraba otra (cada patrulla pertenece a un batallón distinto), se presenta el enfrentamiento entre las dos unidades y como consecuencia pierden la vida varios de los integrantes de una de esas patrullas. Si bien el resultado se atribuye a una acción, se puede considerar la posibilidad de una omisión de parte de uno o de los dos superiores directos de las patrullas, o de los mismos comandantes de éstos.

Surge una pregunta: ¿Tenían los comandantes algún deber jurídico y estaban en capacidad de evitar el resultado? En este contexto, y para reflejar la difícil dinámica del conflicto y sus consecuencias en general, se puede observar que no se cumplió ninguna de las múltiples amenazas del enemigo, pues lo que surgió fue una fatal descoordinación, con el agravante que fue advertida en el Consejo de Seguridad ejecutado días antes, de donde surge otras preguntas: ¿Cuál es el valor probatorio del acta de dicho consejo? ¿Las tropas que sostuvieron el encuentro obedecían órdenes de autoridad competente y con los rigorismos legales? Si las órdenes eran verbales, ¿cómo acreditarlas? ¿Qué pasa con los posibles garantes, si ellos no tuvieron la comunicación oportuna, uno, sobre la salida de sus 
hombres y el otro sobre la presencia de la otra unidad en su jurisdicción? ¿Se creó un riesgo desaprobado y de parte de quién? ¿El principio de confianza? ¿Hay lugar a analizar la competencia de la víctima? Todos estos interrogantes son solo una parte de los posibles dentro de esta situación u otras que se presentan en el conflicto, y que requieren no solo de los conocimientos de la normatividad penal, sino del mismo quehacer militar.

\section{EL FUERO MILITAR.}

Se ha reiterado la dificultad de los operadores de justicia militar y ordinaria para edificar la posición de garante en el ámbito de los delitos omisivos en que pueden incurrir los militares, situación que se ha hecho más notoria por las acciones politiqueras con relación a la figura del fuero militar, alrededor de la cual surgen foros y seminarios de expertos e inexpertos para debatir un tema que, más que trascendental para la Institución Militar, lo es para el mismo Estado, que es el que, administrado por el poder político, tiene la responsabilidad de asegurar a sus ciudadanos, de ahí que su tratamiento exija responsabilidad y seriedad.

Entre otros, en el pasado se discutió y se polemizo el límite que debía tener la Justicia Militar en cuanto esta no debía judicializar civiles, lo que en su momento quizá lo exigía la situación de conflicto del Estado fue debidamente corregido por el legislador en la Constitución de 1991, hoy, más que a la Justicia Castrense en general, se ataca el corazón de esta: el fuero militar, quizá con razón desproporcionada que se fundamenta en la aparición de los mal llamados falsos positivos, en términos penales, homicidios sin ninguna justificación que se le acreditaban a los resultados de la guerra, lo que hoy ha sido reconocido por los Mandos Militares y en buena hora por algunos ejecutores. Pero la necesidad del fuero militar, más que para los militares es una herramienta para bien del Estado y sus asociados, luego mal hace la política, cuando juega peligrosamente con la figura, hasta el punto que valiéndose de un acto administrativo, lograron subordinar a los operadores jurídicos de las jurisdicciones militar y común, y no solo a estos a los mismos litigantes, hasta el punto que fueron desapareciendo los conflictos de competencia. 
El siguiente es el texto del documento que el 14 de junio de 2006 transmitió el Ministerio de Defensa Nacional y la Fiscalía General de la Nación al Comando General de las Fuerzas Militares, a los funcionarios de la Justicia Penal Militar, a los Directores nacionales y seccionales de Fiscalías y al Cuerpo Técnico de Investigación:

“Asunto: Apoyo a Justicia Penal Militar. Como es de su conocimiento, con ocasión de las operaciones propias de las Fuerzas Militares se presentan con alguna frecuencia situaciones en las que se producen hechos que revisten las características del homicidio al cual se refiere el art. 103 del Código Penal, o del homicidio en persona protegida al que alude el art. 135 ibídem; circunstancias que ameritan la inspección técnico científica de los lugares donde hayan ocurrido los hechos, razón por la cual, para facilitar la investigación, el Ministerio de Defensa y la Fiscalía General de la Nación expiden las siguientes directrices: 1. Que los servidores del Cuerpo Técnico de Investigación lleven a cabo las inspecciones de aquellos lugares de los hechos en donde se requiera su concurso técnico científico. 2. Que, mientras se hacen presentes en el lugar de los hechos los servidores del CTI, se realice por parte de los miembros de la Fuerza Pública su protección, atendiendo la obligación legal prevista para el «Primer Respondiente». 3. Que, con el fin de facilitar el procedimiento las Fuerzas Militares deben llevar a cabo el desplazamiento oportuno de los servidores del CTI al lugar de los hechos, procurar su seguridad y el retorno a la respectiva sede. 4. Que luego de la búsqueda, fijación, recolección, embalaje y aseguramiento de las evidencias físicas y elementos materiales de prueba hallados en el lugar, así como las entrevistas de los posibles testigos, los servidores del CTI remitan los respectivos informes a las Unidades de Reacción Inmediata de la Fiscalía. 5. Que el Fiscal de la Unidad de Reacción Inmediata asumirá las diligencias a prevención, atendiendo lo previsto en el artículo 29 de la Carta Política, en concordancia con el artículo 250 ibídem, del artículo 45 del Código de Procedimiento Penal y la Sentencia C-358 de 1997 de la Honorable Corte Constitucional. 6. De ser evidente la existencia de los factores subjetivos y funcionales que justifican el reconocimiento del fuero instituido en el artículo 221 de la Constitución en concordancia con el artículo 250 de la Carta Fundamental, el fiscal de la justicia ordinaria decidirá con prontitud el traslado de la investigación a la Justicia Penal Militar en cuyo caso se mantendrá el apoyo técnico científico del CTI; si no se evidencian los factores enunciados continuará conociendo la Fiscalía General de la Nación, informando de esta situación a la Jurisdicción Penal Militar". (El documento tres años después fue 
objeto de una acción de simple nulidad interpuesta por la ciudadana Lorena Leal Castaño. Proceso Nº 1100103240002009000196 00)."

La aplicación de la figura del fuero militar es gravitante central, tanto para los delitos de acción como para los de omisión, y han sido diferentes las deficiencias que se evidencian en la aplicación del fuero, algunas de ellas que devienen de la misma Justicia Militar y que se evidencian en lo expresado por HenAo Orozco (1994, p. 73), Magistrado de la Sala Jurisdiccional Disciplinaria del Consejo Superior de la Judicatura, en la Revista de las Fuerzas Armadas, donde escribio:

"Mi labor como operador jurídico y como Magistrado de la Corte, cúspide que ostenta la competencia para dirimir esta clase de conflictos, me ha permitido observar los timoratos que en algunas ocasiones muestran los funcionarios de la Justicia Penal Militar, para abocar conocimiento de los asuntos que llegan a sus manos, o en otras palabras, para aprehender competencia que en un momento determinado detentan, ya que constantemente se presentan más conflictos negativos de competencia entre la jurisdicción penal militar y la ordinaria, provocados por funcionarios de la primera, que al primer vistazo del negocio, al respecto deciden desprenderse de él, en detrimento así de una verdadera Justicia Penal Militar."

FERRO TORRES en un artículo sobre la Justicia Militar, escribió:

"Además cuesta admitir que desde una poltrona burocrática, influida por presiones políticas, se lleguen a negar, de la manera como lo hemos venido presenciando, realidades tan palmarias como la existencia de una guerra cruenta que no tiene trazas de concluir, de enfrentamiento de naturaleza guerrera en vastas zonas del territorio colombiano, para parar mientes solo en un sentido de conveniencia partidista, que está situando a quienes ostentan el uniforme de la Fuerza Pública, en una inferioridad aplastante que redunda en desmoralización y apatía. (2007, p. 16)."

HERNÁNDEZ MondRAGÓn afirma, en uno de sus trabajos sobre el Derecho Internacional Humanitario y sobre su aplicación en Colombia, lo siguiente:

"En Colombia, la mayor parte de las discusiones sobre el tema en los años recientes se ha basado en criterios políticos. Siempre se ha discutido si conviene o no aplicarlo, con evidentes prejuicios políticos, sin adecuado conocimiento de las normas desde el punto de vista militarista, de un lado, y las perspectivas 
guerrilleristas o revolucionarias radicales, de otro, y que ponen las necesidades militares o las revolucionarias por encima de las humanitarias haciendo prevalecer aquellas sobre éstas, han sido los criterios determinantes de las decisiones (1994, p. 21).”

El director de la Justicia Penal Militar en una conferencia sobre las estrategias para fortalecerla, manifestó que:

(...) esta ausencia de juridicidad se traduce obviamente en una guerra política, mas, nosotros somos soldados, no tenemos por qué saber sobre derecho. Pero en Colombia es obligatorio que un soldado lo conozca o de lo contrario tendrá problemas al enfrentar los tribunales civiles en Colombia y la Corte Penal Internacional o la Corte Internacional de Derechos Humanos en el exterior. (Escuela Superior de Guerra, 2003-2004, p. 9).

En esa dirección de la importancia paralela que tienen las funciones institucionales y el respeto a la dignidad humana, juega papel importante la preparación integral del militar para que intervenga activamente en las decisiones que atañen al bienestar general, al respecto, es válido retraer a LANDAZÁBAL REYES (1997, p. 75.), en sus Reflexiones sobre el Ejército Colombiano, donde escribió:

"En estos pueblos del tercer mundo, permanentemente hostigados por guerras internas de origen esencialmente político, de graves consecuencias, en las que se defienden democracias inmaduras o ficticias, en las que el poder se impone más por la arbitrariedad del régimen político, que por el imperio severo de la ley, el jefe militar que ignora la política, llegará a las posiciones de la más alta responsabilidad en el mando, con una mentalidad de gendarme, que habrá de impedirle el desempeño del verdadero papel estratégico en la conducción de sus fuerzas para el beneficio político del sistema de gobierno al que sirve con desprendimiento y con honor."

Con esta introducción se puede introducir como la Corte Constitucional ha sido reiterativa en su posición respecto a los elementos estructurales del fuero militar. En una de estas manifestaciones el Alto Tribunal hace algunas precisiones que sin duda inciden en la dinámica que ha tenido esta figura en las investigaciones que la justicia ha tenido que llevar a cabo por los resultados que conllevan las acciones militares en virtud del conflicto 
interno. El Alto Tribunal apunta los modelos de fuero militar: resalta aquellos en que la justicia militar está incorporada a la cadena de mando, otros modelos en que la justicia no se encuentra encuadrada en la línea de mando, y otros donde la justicia militar está inserta en la justicia ordinaria, y finaliza afirmando que en Colombia existe un modelo intermedio que se fundamenta en el artículo 221 de la Carta Política ${ }^{129}$.

Trasciende para este breve resumen la expresión del Alto Tribunal en cuanto a que la justicia militar:

“(...) está integrada por elementos orgánicos y funcionales, objetivos y subjetivos, cuya manifestación concreta se encuentra en la existencia de un órgano jurisdiccional independiente e imparcial -Cortes Marciales o Tribunales Militaresencargado de juzgar los delitos cometidos por los miembros de la fuerza pública en servicio activo - fuerzas militares y policía nacional- en relación con el mismo servicio, y con arreglo a las prescripciones del Código Penal Militar (Corte Constitucional, Sentencia C-141 de 1995 y C-1184 de 2008).”

Sobre estos mismos planteamientos jurisprudenciales, los elementos objetivo y subjetivo han sido desarrollados tanto por la Corte Constitucional ${ }^{130}$ como por la Corte Suprema de Justicia $^{131}$. Las precisiones son concretas y claras, se puede tomar como ejemplo lo manifestado por el Tribunal penal en el Proceso $\mathrm{N}^{\circ} 9996$ de 1996, que resolviendo en casación una nulidad propuesta en un caso de homicidio de un soldado en la humanidad de otro compañero, refiriéndose al fuero militar, expresó:

"Dos son las condiciones que el artículo 221 de la Constitución Nacional establece para que la investigación y juzgamiento de los delitos cometidos por miembros de la Fuerza Pública sea de conocimiento de la justicia penal militar: a) Que el imputado al

\footnotetext{
${ }^{129}$ El Acto Legislativo 02 de 1995 lo consagro así: "De los delitos cometidos por los miembros de la Fuerza Pública en servicio activo, y en relación con el mismo servicio, conocerán las Cortes marciales o tribunales Militares con arreglo a las prescripciones del Código Penal Militar. Tales Cortes o Tribunales estarán integrados por miembros de la Fuerza Pública en servicio activo o en retiro".

${ }^{130}$ Entre otras, se pueden confrontar las Sentencias C-358 de 1997, SU-1184 de 2001 y C-1214 de 2001.

${ }^{131}$ Se puede confrontar en los Procesos N 9996 de 1996 y 25682 de 2009.
} 
ejecutar la conducta ilícita se encuentre en servicio activo; y, b) Que el delito guarde relación con el servicio.

"Para la aplicación del régimen foral militar no basta, por consiguiente, que se tenga la calidad de miembro activo de la fuerza pública al ejecutar el hecho punible; es necesario, además, que el delito esté sustancialmente vinculado con la actividad militar o policial desarrollada por el sujeto agente. Si este nexo no se presenta, será la justicia ordinaria, no la militar, la que deba conocer del asunto."

En la Sentencia C-358 de 1997 manifestó el Alto Tribunal:

"El miembro de la Fuerza Pública, así se encuentre en servicio activo, ha podido cometer el crimen al margen de la misión castrense encomendada: en este caso, el solo hecho de estar en servicio activo no lo exime de ser sometido al derecho penal común. Las prerrogativas y la investidura que ostentan los miembros de la fuerza pública pierden toda relación con el servicio cuando deliberadamente son utilizadas para cometer delitos comunes, los cuales no dejan de serlo porque el agente se haya aprovechado de las mencionadas prerrogativas e investidura, ya que ellas no equivalen a servicio ni, de otro lado, tienen la virtud de mutar el delito común en un acto relacionado con el mismo. El simple hecho de que una persona esté vinculada a la fuerza pública no dota a sus propósitos delictivos de la naturaleza de misión de la fuerza pública. Ellos continúan siendo simplemente la voluntad delincuencial imputable a la persona, desconectada del servicio público de la defensa y de la seguridad pública, la cual en un plano de estricta igualdad deberá ser investigada y sancionada según las normas penales ordinarias."

Más adelante la misma Sentencia expresa:

“(... 9. Antes de decidir acerca de la aplicación del derecho penal militar en un caso concreto es indispensable que el juez, al analizar el contexto fáctico en el que se cometió el acto delictivo, distinga y confronte la conducta efectivamente realizada y la operación o acción propios del servicio. Tratándose del delito típicamente militar y del delito común adaptado a la función militar -o «militarizado» como lo señalan algunos autores-, tanto el elemento personal como el funcional, constitutivos de la justicia penal militar, son forzosamente estimados por el juez, habida cuenta de que la norma penal los involucra conjuntamente. En el caso de los delitos comunes objeto de recepción pasiva por parte del Código Penal Militar, la ausencia de un condicionamiento positivo estricto dentro del mismo tipo penal, que supedite la competencia de la justicia penal militar a su vinculación directa con un acto u operación propios del servicio, dificulta la decisión acerca de cuál es el derecho penal aplicable. Esa decisión está siempre expuesta a dos peligros igualmente graves y lesivos de la igualdad y del debido proceso: por una parte, la discrecionalidad judicial para definir el juez natural y el 
derecho aplicable; por otra, la conversión del fuero en privilegio personal y el socavamiento injustificado de la jurisdicción ordinaria. Los mencionados peligros pueden menguarse, sin embargo, si se parte de la definición del fuero penal militar como una excepción a la regla del juez natural general. Ello significa que en todos aquellos casos en los que no aparezca diáfanamente la relación directa del delito con el servicio habrá de aplicarse el derecho penal ordinario.

10. ( ...)

a. que para que un delito sea de competencia de la justicia penal militar debe existir un vínculo claro de origen entre él y la actividad del servicio, esto es, el hecho punible debe surgir como una extralimitación o un abuso de poder ocurrido en el marco de una actividad ligada directamente a una función propia del cuerpo armado. Pero aún más, el vínculo entre el delito y la actividad propia del servicio debe ser próximo y directo, y no puramente hipotético y abstracto. Esto significa que el exceso o la extralimitación deben tener lugar durante la realización de una tarea que en sí misma constituya un desarrollo legítimo de los cometidos de las Fuerzas Armadas y la Policía Nacional. Por el contrario, si desde el inicio el agente tiene propósitos criminales, y utiliza entonces su investidura para realizar el hecho punible, el caso corresponde a la justicia ordinaria, incluso en aquellos eventos en que pudiera existir una cierta relación abstracta entre los fines de la Fuerza Pública y el hecho punible del actor. En efecto, en tales eventos no existe concretamente ninguna relación entre el delito y el servicio, ya que en ningún momento el agente estaba desarrollando actividades propias del servicio, puesto que sus comportamientos fueron ab initio criminales.

b. que el vínculo entre el hecho delictivo y la actividad relacionada con el servicio se rompe cuando el delito adquiere una gravedad inusitada, tal como ocurre con los llamados delitos de lesa humanidad. En estas circunstancias, el caso debe ser atribuido a la justicia ordinaria, dada la total contradicción entre el delito y los cometidos constitucionales de la Fuerza Pública. Al respecto es importante mencionar que esta Corporación ya ha señalado que las conductas constitutivas de los delitos de lesa humanidad son manifiestamente contrarias a la dignidad humana y a los derechos de la persona, por lo cual no guardan ninguna conexidad con la función constitucional de la Fuerza Pública, hasta el punto de que una orden de cometer un hecho de esa naturaleza no merece ninguna obediencia. En efecto, en la Sentencia C-578 de 1995, en el fundamento jurídico 5.3.1. Se expresó:

"La orden del servicio es la que objetivamente se endereza a ejecutar los fines para los cuales está creada la institución. Una orden que de manera ostensible atente contra dichos fines o contra los intereses superiores de la sociedad, no puede reclamar válidamente obediencia. La orden de agredir sexualmente a una persona o de infligirle torturas, bajo ninguna circunstancia puede merecer el calificativo de 
orden del servicio. Estas acciones, que se enuncian a título de ilustración, son ajenas completamente al objeto de la función pública confiada a los militares y al conjunto de sus deberes legales".

Por consiguiente, un delito de lesa humanidad es tan extraño a la función constitucional de la Fuerza Pública que no puede jamás tener relación con actos propios del servicio, ya que la sola comisión de esos hechos delictivos disuelve cualquier vínculo entre la conducta del agente y la disciplina y la función propiamente militar o policial, por lo cual su conocimiento corresponde a la justicia ordinaria."

Posteriormente la sentencia SU-1184 de 2001 especifica con claridad las circunstancias en que una omisión de la Fuerza Pública se considera un acto fuera del servicio y se refiere en concreto al fuero militar, así:

"Esto significa que no pueden quedar amparadas por el fuero penal militar, las siguientes omisiones: i) las que se producen en el contexto de una operación que $a b$ initio buscaba fines contrarios a los valores, principios o derechos consagrados en la Carta (surgió para capturar arbitrariamente a alguien y no se impide la vulneración de este derecho) o ii) las que surgen dentro de una operación iniciada legítimamente, pero en su desarrollo se presenta una desviación esencial del curso de la actividad (no se impide el maltrato de una persona que ya no presenta ninguna clase de resistencia en un combate) o iii) cuando no se impiden las graves violaciones a los Derechos Humanos o al Derecho Internacional Humanitario (un miembro de la fuerza pública que tiene el deber de evitar un daño a la población civil, no evita la producción del resultado). En los anteriores casos, siempre es indispensable que el garante tenga dentro de su ámbito de competencia el deber concreto de evitar los resultados que vulneran los derechos fundamentales. Si el miembro de la fuerza pública tiene un deber específico de evitar el resultado (ostenta una posición de garante) y no inicia la acción de salvamento a pesar de que contaba con la posibilidad material de hacerlo (tenía a su disposición medios logísticos para la protección de los bienes jurídicos), se le imputa el resultado lesivo que no impidió y no la simple inobservancia de un deber funcional. Por consiguiente, si el garante no inicia una acción de salvamento para proteger los bienes jurídicos que se encuentran dentro de su ámbito de responsabilidad, se le atribuye la violación a los Derechos Humanos como si se tratara de una conducta activa." 
Recientemente la Corte Constitucional en la Sentencia C-1214 de 2001, señaló:

"De ahí que haya dicho que son dos elementos que deben estar presentes para que opere la competencia de las Cortes Marciales o Tribunales Militares. El primero, de carácter subjetivo: pertenecer a la institución castrense y ser miembro activo de ella; el segundo, de carácter funcional, por cuanto el delito cometido debe tener relación con el servicio."

Y más adelante precisó:

"Son de competencia de la jurisdicción penal militar no sólo aquellos delitos que por su naturaleza únicamente pueden ser cometidos por los miembros activos de la fuerza pública, tales como el abandono del comando y del puesto; el abandono del servicio; la insubordinación, etc., sino aquellos comunes que se relacionen directa y sustancialmente con las funciones que constitucionalmente está llamada a cumplir la fuerza pública."

Seguido de este breve contexto jurisprudencial, hay que registrar que el Código Penal Militar (Ley 1407 de 2010), en el contenido de los artículos $1^{\circ 132}, 2^{\circ 133}, 3^{\circ 134}$ y $171^{135}$ abraza el marco conceptual del artículo 221 de la Constitución Nacional. De una parte transcribe la norma foral, y de otra despeja cuáles son los delitos relacionados con el servicio, y cuáles son los no relacionados con el servicio, (Delitos de tortura, genocidio, desaparición forzada, de lesa humanidad o aquellos que atenten contra el Derecho Internacional Humanitario.) y hace claridad en cuanto aquellos delitos cometidos por personal en actividad y en relación con el

132 “Artículo $1^{\circ}$. Fuero Militar. De los delitos cometidos por los miembros de la Fuerza Pública en servicio activo, y en relación con el mismo servicio, conocerán las Cortes Marciales o los Tribunales Militares, con arreglo a las disposiciones de este Código. Tales Cortes o Tribunales estarán integrados por miembros de la Fuerza Pública en servicio activo o en retiro".

133 "Artículo $2^{\circ}$. Delitos relacionados con el servicio. Son delitos relacionados con el servicio aquellos cometidos por los miembros de la Fuerza Pública en servicio activo dentro o fuera del territorio nacional, cuando los mismos se deriven directamente de la función militar o pública que la Constitución, la ley y los reglamentos le han asignado".

${ }_{134}$ “Artículo $3^{\circ}$. Delitos no relacionados con el servicio. No obstante lo dispuesto en el artículo anterior, en ningún caso podrán relacionarse con el servicio los delitos de tortura, genocidio, desaparición forzada, de lesa humanidad o aquellos que atenten contra el Derecho Internacional Humanitario entendidos en los términos definidos en convenios y tratados internacionales ratificados por Colombia, ni las conductas que sean abiertamente contrarias a la función constitucional de la Fuerza Pública y que por su sola comisión rompan el nexo funcional de agente con el servicio".

135 "Artículo 171. Delitos comunes. Cuando un miembro de la Fuerza Pública, en servicio activo y en relación con el mismo servicio, cometa delito previsto en el Código Penal ordinario o leyes complementarias, será investigado y juzgado de conformidad con las disposiciones del Código Penal Militar". 
servicio que se contemplen en el Código Ordinario o leyes complementarias, los cuales deben ser investigados de acuerdo a la normatividad penal militar. Se apunta aquí que además el artículo 10 del Código Militar ${ }^{136}$, en virtud del principio de igualdad ante la ley, expresa que: "La Ley Penal Militar se aplicará a los miembros de la Fuerza Pública, sin tener en cuenta circunstancias diferentes a las establecidas en la Constitución y en la ley".

Se considera y se puede afirmar, entonces, que el derecho al fuero militar tiene un marco constitucional y legal bastante despejado en lo que son sus elementos esenciales, son claros los elementos objetivo y subjetivo. En cuanto al elemento subjetivo que se materializa cuando el sujeto activo de la conducta es miembro activo de la Institución, no se presenta mayor polémica. Como lo indica la lógica y los militares lo entienden, en complemento al elemento subjetivo y en dirección al objetivo, un miembro de la Institución que se vea involucrado en delitos de tráfico de estupefacientes, contrabando, lavado de activos, conductas sexuales u otros comportamientos que no tienen relación directa con el servicio, no puede buscar refugio en el fuero militar ni la jurisdicción castrense puede ampararlo.

Sobre el componente objetivo, referente a las competencias funcionales muy inherentes para la consolidación de la posición de garante y que se soporta sobre la base de que el delito tenga relación directa con el servicio, recaen diversas situaciones que giran en torno precisamente al núcleo central del fuero militar: la premisa debe ser que la acción desarrollada tiene relación directa con el servicio, y por tanto la competencia corresponde a la jurisdicción militar, aún en casos de que se hayan presentado excesos (Cfr. Sentencia C358 de 1997), y es esta jurisdicción la que en derecho asume la investigación o se declara incompetente para conocer, por divisar que la acción militar no estaba direccionada a la misión constitucional, no puede ser de otra manera, sus pares conocedores del quehacer

\footnotetext{
136 “Artículo 10. Igualdad ante la ley. La Ley Penal Militar se aplicará a los miembros de la Fuerza Pública, sin tener en cuenta circunstancias diferentes a las establecidas en la Constitución y en la ley. El Funcionario Judicial tendrá especial consideración cuando se trata de valorar el injusto, la culpabilidad y las consecuencias jurídicas del delito, en relación con los miembros de la Fuerza Pública que se encuentran en las situaciones descritas en el inciso final del artículo 13 de la Constitución Política".
} 
militar con la investigación previa deciden en derecho si les corresponde la competencia o por el contrario, esta es de la jurisdicción común.

Ahora bien, si el militar, constitucional y legalmente en su condición de funcionario público tiene exigencias superiores al ciudadano del común, lo que obedece a la naturaleza de la misión institucional, y particularmente cuando se trata de proteger bienes jurídicos como la vida y la libertad de las personas, debe ser proporcional el respeto a su derecho al fuero militar y no deberían surgir de parte de la Administración (Política y Militar) actos abiertamente inconstitucionales e ilegales que les elimina de un plumazo el derecho foral, como se conoció, cuando el Ministerio de Defensa Nacional en junio de 2006 decidió, mediante un oficio ya enunciado, eliminar el procedimiento natural, constitucional y legal, y colocó a la justicia ordinaria a decidir per se la competencia en procesos originados por los resultados de operaciones en combates y anuló las competencias funcionales de la jurisdicción militar, quienes están obligados a tener el conocimiento del arte militar y la obligación constitucional y legal de actuar en derecho, sea asumiendo la investigación o delegando la competencia a la justicia ordinaria mediante resolución fundada en los hechos, en un razonamiento probatorio y jurídico acorde con lo establecido en el artículo 217 de la Constitución Nacional, con la ley y con los derroteros trazados en la jurisprudencia de las Altas Cortes. Para este razonamiento probatorio y jurídico, con miras a determinar la competencia, se considera necesario el conocimiento suficiente de las múltiples variantes que se presentan en una acción militar, de ahí las especialidades que la Fiscalía General de la Nación tiene. Dentro de su estructura existen unidades especializadas: la de Derechos Humanos y Derecho Internacional Humanitario, la de delitos contra la Administración Pública y la de Antinarcóticos e Interdicción Marítima, entre otras. En esta dirección surgen algunas consideraciones que tienen incidencia directa en el proceso: a) el operador de justicia no sabe del quehacer militar; b) no estuvo en el sitio de los hechos; c) no conoció de cerca ni la necesidad, ni el desarrollo, ni los resultados de la operación militar; d) no estuvo en la escena del crimen y tampoco fueron miembros los miembros de la Policía Judicial; e) por lo general los levantamientos de cadáveres y toda la cadena de custodia ha sido deficiente; f) se aleja la posibilidad de identificar e individualizar al (los) sujeto (s) activo 
(s) de la conducta, y g) figuras dogmáticas como el dolo y la coautoría son analizadas superficialmente, entre otros.

De otra parte. La legislación penal colombiana contempla el desplazamiento forzado en dos tipos penales: uno en el artículo 159, en los delitos contra personas y bienes protegidos por el Derecho Internacional Humanitario, y el otro en el artículo 180, en los delitos contra la Libertad Individual y otras Garantías. En común, los dos tipos penales hacen referencia al accionar militar y al Derecho Internacional Humanitario. En el primero hace referencia al conflicto interno como generador del desplazamiento, y en el segundo se basa en la arbitrariedad, en el cual es notorio que también se puede presentar como efecto del conflicto interno, luego queda a criterio del juez calificarlo y hacerlo protagonista como delito de lesa humanidad que contempla la Corte Penal Internacional.

En este evento del desplazamiento forzado, el ilícito puede generarse por la real intensidad de las acciones militares en una determinada zona de operaciones, y/o por presión de los grupos al margen de la ley, o en extremo, se puede presentar porque un oficial en servicio activo (elemento subjetivo) se presta para impulsar un desplazamiento (elemento objetivo), pero también se presentan falsas denuncias en busca de dadivas del Gobierno de turno, luego es el Juez Militar el que debe definir la competencia en derecho. El comportamiento no está tipificado en el Estatuto Militar, pero sí se registra en los dos artículos del Código Común, y como ya se apuntó en la estructura de los tipos penales, está inmerso el accionar militar. Sin embargo la competencia es de la Fiscalía General de la Nación, que asume la investigación, luego es exigible que el operador de justicia goce del conocimiento del ambiente militar, ya sea para este tipo penal, o que surja de las acciones que se desarrollan en el marco del conflicto interno, incluyendo aquí aquellas investigaciones donde precisamente la jurisdicción militar ha renunciado a la competencia.

Distintas circunstancias dentro de la Justicia Militar han hecho que el fuero sea atacado desde diferentes flancos: a) dentro de los miembros de la justicia castrense hay funcionarios que adolecen del conocimiento del ambiente militar; b) la no presencia de la Policía 
Judicial y/o del juez militar en la escena de los hechos; c) consecuencialmente la escena de los hechos es contaminada; d) el levantamiento de cadáveres se hace sin los protocolos dispuestos; e) el acercamiento de pruebas o es negligente o se dificulta por el mismo desarrollo de las operaciones; f) se carece de investigadores especializados que puedan aportar pruebas técnicas; g) se carece de doctrina y jurisprudencia que procure dentro de las circunstancias de tiempo, modo y lugar, establecer puntos de referencia en cuanto a la individualización del (los) sujeto (s) activo (s) de la conducta, y a figuras como la coautoría y el dolo, entre otros; h) las colisiones de competencia negativas interpuestas por funcionarios judiciales militares sin razonamientos fácticos, probatorios y jurídicos; i) la subordinación del Juez Militar como efecto de la misma jerarquización, y j) deficiencias funcionales de los Comandos y Estados Mayores en el acompañamiento y control de los eventos judiciales, de tal manera que les evite o les permita enfrentar los procesos penales.

Finalmente, surgen dos elementos que tienen relación con el fuero: el primero es la carencia de policía judicial por parte de la justicia castrense, y el segundo es la falta de una Sala Especializada tanto en el Tribunal Militar como en el Consejo Superior de la Judicatura, con expertos penalistas y conocedores del tema militar, idóneos para resolver en derecho los conflictos de competencias que tenga que dirimir.

Entonces, tomando como un referente las anteriores consideraciones, más que la reforma de la norma constitucional que regula el fuero militar, se considera gravitante que la funcionalidad de las jurisdicciones ordinaria y militar se fortalezca intelectual y éticamente. En lo primero, que sea mediante sus propias actuaciones que se respete el fuero militar y que sus manifestaciones jurisprudenciales desarrollen las figuras dogmáticas y fortalezcan el respeto al debido proceso y a la presunción de inocencia, en el contexto de una acción militar en un país en conflicto y acorde con la normativa dentro del conjunto del bloque de constitucionalidad y en cuanto a lo segundo, no olvidar que se tiene una amplia responsabilidad profesional a la hora de impartir justicia que repercute en la credibilidad y respeto que debe tener esa alta dignidad ante la sociedad. 
Se cierra esta breve posición sobre el fuero militar con una frase pronunciada por AlBerto LlerAS CAMARGO: "Si hay algo que castigar, que depurar, que corregir, se castigará, se corregirá, se depurará por las propias Fuerzas Armadas, por su justicia, por las reglas de su disciplina excepcional y no con intervención de acciones políticas parciales y parcializadas". 


\section{CONCLUSIONES}

La avanzada en los campos académicos y prácticos de los conceptos de Derechos Humanos y Derecho Internacional Humanitario, que se materializan en las múltiples dificultades jurídicas en ese campo que afrontan las Fuerzas Militares, exige la valoración del honor militar como piedra angular, debe fortalecerse un replanteamiento estratégico de las herramientas doctrinales a que puede y debe acudir la Institución castrense.

Sobre la base de honor militar, como piedra angular institucional, el militar debe exponer internamente sus reglamentos manuales y protocolos a una estricta revisión para hacerlos coherentes entre sí, y a la vez enmarcarlos en las normas penales lo mas rígidamente posible; en esta dirección los comandos y sus Estados Mayores deben identificar sus debilidades y fortalezas para lograr precisión en las normas militares operacionales a aplicar; la necesidad surge de la manera como se ejecutan las acciones de los agentes generadores de violencia (FARC - ELN - Bacrim - Delincuencia Organizada Delincuencia Común) y de las normas constitucionales y del Bloque de constitucionalidad que rige.

La diversidad de Jefaturas y Escuelas, limita la rapidez y precisión con la que se debe alcanzar la unidad doctrinal, para contrarrestar la situación de conflicto, la avanzada en la aplicación de los Derechos Humanos y el Derecho Internacional Humanitario y los debates jurídicos y legales que giran en torno a la misión de las fuerzas militares que estas requieran de una preparación más avanzada que las previnieran de las acciones penales propias de las consecuencias del conflicto interno colombiano.

La acción de los comandos y sus estados mayores no se refleja en la dinámica de los manuales y reglamentos de la institución comparada con la problemática que le arroja el conflicto con la exigencia de las normas del Derecho Internacional Humanitario, la estática y/o la intromisión de extraños y de mismos militares ingenuos en la doctrina que se debe adoptar, ha tergiversado la responsabilidad profesional de análisis, reflexión, y 
creatividad respecto al papel que desempeñan los manuales, reglamentos y protocolos militares que se ejecutan en el contexto de las operaciones militares y que tienen relación directa con la posición de garante que muy frecuentemente ejerce los miembros de institución castrense, y no menos importantes si se tiene en cuenta que en torno a la misión que cumplen las Fuerzas Militares se mueven trascendentales figuras del derecho penal como la coautoría, el dolo, el principio de confianza, la obediencia debida, y otras como la creación de riesgos, que exigen a estas alturas una correcta interpretación del militar, a estas figuras se adiciona la correcta interpretación que se le debe dar al significado del objetivo militar, a los principios de necesidad, proporcionalidad, distinción y dignidad humana; el conocimiento de este contexto no se refleja indicativamente en los actos administrativos que se adelantan para el ejercicio de las operaciones militares

Las deficiencias en la elaboración de los actos administrativos representan una notoria debilidad a la hora de ejecutar una defensa jurídica. Sin duda, todos y cada uno de los componentes estructurales de la apreciación de situación tiene incidencia a la hora de determinar la posibilidad de ejecutar la acción que impida el resultado que se está en el deber de evitar; son gravitantes: el estudio del enemigo con todos los factores que él implica, el análisis de las propias tropas, el conocimiento y análisis de la topografía, de la hidrografía, de las condiciones atmosféricas y de las vías terrestres, entre tantos aspectos, lo que incide notoriamente, a más de la posibilidad de empleo de las tropas, la misma velocidad con que éstas puedan acudir a la protección de los bienes jurídicos. En este mismo sentido se está marcando con anticipación las posibilidades del empleo del apoyo de fuegos y de helicópteros y aviones de combate, sea para transporte de personal o para apoyar con fuegos.

Es indudable que los miembros de la Institución castrense, requieren de una aglomeración documental relativa al Derecho Penal y permanente capacitación al respecto, de tal manera que puedan constituir un capital instrumental que refleje su esfuerzo en la práctica en esos álgidos temas de los Derechos Humanos y del Derecho Internacional Humanitario, que en múltiples ocasiones se presentan, no como acciones dolosas, sino como verdaderos 
resultados de la guerra. En esta dirección la biblioteca militar y las academias tienen un enorme campo de estudio y aprendizaje basados en: a) naturalmente, la Constitución, los códigos Penal Común y Penal Militar; b) las manifestaciones jurisprudenciales, particularmente de la Corte Constitucional y de la Corte Suprema de Justicia; c) el Estatuto de la Corte Penal Internacional; d) Los convenios de Ginebra y sus protocolos; e) los reglamentos y manuales militares, y f) los estudios, análisis y reflexiones de sus actos administrativos: apreciaciones de situación del Comandante y del Estado Mayor, informes de inteligencia, órdenes de operaciones, informes de patrullaje, resoluciones que asignan jurisdicción a las Unidades Militares (definen la capacidad funcional, material y territorial, en la posición de garante), los libros de registros operacionales, y en general todo tipo de comunicaciones radiales o escritas que se administren en las operaciones que se relacionan con los bienes jurídicos de la vida y la libertad.

Finalmente, la agresividad de las distintas manifestaciones de la guerra, entre estas la gran cantidad de militares privados de la libertad, debe exige un comprometimiento serio, responsable y sin vacilación de la clase política, pero particularmente de quienes ejercen como "autoridad civil" conforme a las normas constitucionales y legales (la rigidez de los Consejos de Seguridad), así como la realización de un esfuerzo real en dirección a facilitar normas legales acordes con las condiciones de desorden público y no relegar a los integrantes de las Fuerzas Militares cono ciudadanos de segundo orden cuando se trata del respeto de sus derechos fundamentales.

Para terminar, este trabajo, como un inicio de investigación mixta entre documentos, análisis y ejemplos reales, aunado con otros que deben circular, solo pretende servir a la institución militar, a litigantes y "operadores de justicia" para enfrentar los procesos penales que deben librar los miembros de las Instituciones Militares, la cual es prolongada y cada día será más exigente en argumentos legales. 
Tabla 1. Omisión Propia en el Código Penal Militar.

\begin{tabular}{|c|c|c|c|}
\hline & $\begin{array}{l}\text { DECRETO } 2550 \\
\text { DE } 1988\end{array}$ & $\begin{array}{l}\text { LEY } 522 \\
\text { DE } 1999\end{array}$ & $\begin{array}{l}\text { LEY } \\
1407 \text { DE } 2010\end{array}$ \\
\hline & $\begin{array}{l}\text { ARTÍCULO } \\
\begin{array}{l}\text { Omisión en } \\
\text { abastecimiento. }\end{array}\end{array}$ & $\begin{array}{l}\text { ARTÍCULO } \\
\begin{array}{l}\text { Omisión en } \\
\text { abastecimiento }\end{array}\end{array}$ & $\begin{array}{l}\text { ARTíCULO } \\
\begin{array}{l}\text { Omisión en } \\
\text { abastecimiento. }\end{array}\end{array}$ \\
\hline & $\begin{array}{l}\text { ARTÍCULO } \mathbf{1 2 5} \text {. } \\
\text { Cobardía por omisión. }\end{array}$ & $\begin{array}{lr}\text { ARTíCULO } & \mathbf{1 3 8} \\
\begin{array}{l}\text { Cobardía } \\
\text { omisión. }\end{array} & \text { por } \\
\end{array}$ & $\begin{array}{l}\text { ARTÍCULO } \mathbf{1 1 9 .} \\
\text { Cobardía por omisión. }\end{array}$ \\
\hline & $\begin{array}{lr}\text { ARTÍCULO } & \mathbf{1 3 9} . \\
\text { Requisición } & \text { con } \\
\text { omisión } & \mathrm{de} \\
\text { formalidades. } & \end{array}$ & $\begin{array}{lr}\text { ARTÍCULO } & \mathbf{1 7 7} . \\
\text { Requisición } & \text { con } \\
\text { omisión } & \mathrm{de} \\
\text { formalidades } & \end{array}$ & $\begin{array}{lr}\text { ARTÍCULO } & \mathbf{1 5 8} . \\
\text { Requisición } & \text { con } \\
\text { omisión } & \mathrm{de} \\
\text { formalidades } & \end{array}$ \\
\hline $\begin{array}{c}\text { EL } \\
\text { DELITO } \\
\text { DE } \\
\text { OMISIÓN }\end{array}$ & & $\begin{array}{lr}\text { ARTÍCULO } & \mathbf{1 6 4} . \\
\text { Omisión } & \text { en } \\
\text { naufragio, catástrofe } \\
\text { o siniestro. }\end{array}$ & $\begin{array}{l}\text { ARTÍCULO } \mathbf{1 4 5} \text {. } \\
\text { Omisión en naufragio, } \\
\text { catástrofe o siniestro. }\end{array}$ \\
\hline & $\begin{array}{l}\text { ARTÍCULO } \\
\text { Omisión de auxilio. }\end{array}$ & $\begin{array}{l}\text { ARTíCULO } 167 . \\
\text { Omisión de auxilio. }\end{array}$ & $\begin{array}{l}\text { ARTÍCULO } \\
\text { Omisión de auxilio. }\end{array}$ \\
\hline $\begin{array}{c}\text { CÓDIGO } \\
\text { PENAL } \\
\text { MILITAR } \\
\text { COLOMBIANO }\end{array}$ & $\begin{array}{l}\text { ARTÍCULO } \mathbf{1 6 5} \text {. } \\
\text { Omisión de inutilizar } \\
\text { buque, aeronave, o } \\
\text { carro de combate. }\end{array}$ & $\begin{array}{l}\text { ARTÍCULO } \mathbf{1 6 8} \text {. } \\
\text { Omisión } \\
\text { inutilizar buque, } \\
\text { aeronave, carro de } \\
\text { combate o medio de } \\
\text { transporte colectivo } \\
\text { de la Fuerza Pública. }\end{array}$ & $\begin{array}{l}\text { ARTíCULO } \\
\text { Omisión de } \\
\text { inutilizar buque, } \\
\text { aeronave, carro de } \\
\text { combate o medio de } \\
\text { transporte colectivo de } \\
\text { la Fuerza Pública. }\end{array}$ \\
\hline & $\begin{array}{l}\text { ARTÍ́CULO } \\
\text { Prevaricato } \\
\text { omisión. }\end{array}$ & & \\
\hline & $\begin{array}{l}\text { ARTÍCULO } \\
\text { Abuso de autoridad por } \\
\text { omisión de denuncia. }\end{array}$ & & \\
\hline & $\begin{array}{l}\text { ARTÍCULO } \\
\text { Omisión de apoyo. }\end{array}$ & $\begin{array}{l}\text { ARTíCULO } \mathbf{1 8 6 .} \\
\text { Omisión de apoyo } \\
\text { especial. }\end{array}$ & 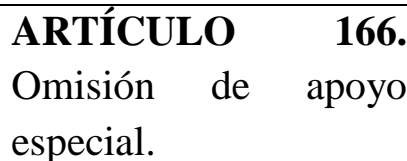 \\
\hline
\end{tabular}


Tabla 2. Omisión propia en el Código Penal Común

\begin{tabular}{|c|c|c|}
\hline \multirow{11}{*}{$\begin{array}{c}\text { OMISIÓN } \\
\text { PROPIA } \\
\text { CÓDIGO } \\
\text { PENAL } \\
\text { COLOMBIANO }\end{array}$} & DECRETO 100 DE 1980 & LEY 599 DE 2000 \\
\hline & & $\begin{array}{l}\text { ARTíCULO 131.Omisión de } \\
\text { socorro. }\end{array}$ \\
\hline & & $\begin{array}{l}\text { ARTÍCULO 152. Omisión de } \\
\text { medidas de socorro y asistencia } \\
\text { humanitaria. }\end{array}$ \\
\hline & & $\begin{array}{l}\text { ARTÍCULO 161. Omisión de } \\
\text { medidas de protección a la } \\
\text { población civil. }\end{array}$ \\
\hline & & $\begin{array}{l}\text { ARTÍCULO 219B. Omisión de } \\
\text { denuncia. }\end{array}$ \\
\hline & & $\begin{array}{l}\text { ARTÍCULO 325. Omisión de } \\
\text { control. }\end{array}$ \\
\hline & & $\begin{array}{l}\text { ARTíCULO 402. Omisión del } \\
\text { agente retenedor o recaudador. }\end{array}$ \\
\hline & $\begin{array}{l}\text { ARTÍCULO } 150 . \\
\text { Prevaricato por Omisión. }\end{array}$ & $\begin{array}{l}\text { ARTÍCULO 414. Prevaricato por } \\
\text { omisión. }\end{array}$ \\
\hline & $\begin{array}{l}\text { ARTÍCULO 153. Abuso } \\
\text { de autoridad por omisión } \\
\text { de denuncia. }\end{array}$ & $\begin{array}{llll}\text { ARTÍCULO } 417 . & \text { Abuso } & \text { de } \\
\text { autoridad por omisión } & \text { de } \\
\text { denuncia. } & & & \\
\end{array}$ \\
\hline & $\begin{array}{l}\text { ARTíCULO 160. Omisión } \\
\text { de Apoyo. }\end{array}$ & $\begin{array}{l}\text { ARTÍCULO 424. Omisión de } \\
\text { apoyo. }\end{array}$ \\
\hline & & $\begin{array}{l}\text { ARTÍ́CULO 441. Omisión de } \\
\text { denuncia de particular. }\end{array}$ \\
\hline
\end{tabular}




\section{Tabla 3}

"Artículo 131. Omisión de socorro. El que omitiere, sin justa causa, auxiliar a una persona cuya vida o salud se encontrare en grave peligro, incurrirá en prisión de dos (2) a cuatro (4) años". (La pena fue agravada acorde a la ley 890 de 2004.)

\begin{tabular}{|c|c|c|c|}
\hline TIPO OBJETIVO & $\begin{array}{c}\text { TIPO } \\
\text { SUBJETIVO }\end{array}$ & ANTIJURICIDAD & CULPABILIDAD \\
\hline $\begin{array}{l}\text { Conducta: } \\
\text { Verbo determinador: } \\
\text { No auxiliar. } \\
\text { Sujeto Activo: } \\
\text { Cualificado. En } \\
\text { quien recae el deber } \\
\text { de socorro. } \\
\text { Sujeto Pasivo: } \\
\text { Indeterminado. La } \\
\text { persona en peligro } \\
\text { Objeto Jurídico: } \\
\text { La vida, la } \\
\text { integridad personal. } \\
\text { Objeto Material: } \\
\text { Persona en situación } \\
\text { de peligro. }\end{array}$ & $\begin{array}{l}\begin{array}{l}\text { Modalidad } \\
\text { dogmática: } \\
\text { Conducta dolosa. }\end{array} \\
\text { Atipicidad } \\
\text { Subjetiva: } \\
\text { Error de tipo. } \\
\text { Ausencia de dolo } \\
\text { sobre } \\
\text { circunstancias } \\
\text { del sujeto pasivo } \\
\text { y objeto material. }\end{array}$ & $\begin{array}{l}\text { Juicio de } \\
\text { contradicción } \\
\text { material: } \\
\text { Peligro efectivo para la } \\
\text { vida y la integridad } \\
\text { personal. } \\
\text { Causas justificación } \\
\text { admisibles: } \\
\text { Cumplimiento de un } \\
\text { deber legal, orden } \\
\text { legítima, ejercicio de un } \\
\text { derecho, actividad } \\
\text { lícita, estado de } \\
\text { necesidad. } \\
\text { Causas justificación } \\
\text { inadmisibles: } \\
\text { Consentimiento sujeto } \\
\text { pasivo, ejercicio de } \\
\text { cargo público, legítima } \\
\text { defensa. }\end{array}$ & $\begin{array}{l}\text { Causas de } \\
\text { Inculpabilidad. } \\
\text { Por inexigibilidad de } \\
\text { comportamiento } \\
\text { diferente: } \\
\text { Fuerza Mayor, caso } \\
\text { fortuito, insuperable } \\
\text { coacción ajena, miedo } \\
\text { insuperable. } \\
\text { Por incapacidad de } \\
\text { culpabilidad: } \\
\text { Inimputabilidad por } \\
\text { trastorno mental. } \\
\text { Por falta de } \\
\text { conocimiento de la } \\
\text { antijuricidad: } \\
\text { Excepcionalmente error } \\
\text { de prohibición. }\end{array}$ \\
\hline
\end{tabular}

Fuente: Pabón, 2006, pág. 111 


\section{Tabla 4}

"Artículo 152. Omisión de medidas de socorro y asistencia humanitaria. El que, con ocasión y en desarrollo de conflicto armado y estando obligado a prestarlas, omita las medidas de socorro y asistencia humanitarias a favor de las personas protegidas, incurrirá en prisión de tres (3) a cinco (5) años y multa de cincuenta (50) a cien (100) salarios mínimos legales mensuales vigentes". (La pena fue agravada acorde a la ley 890 de 2004.)

ARTíCULO 152. Omisión de medidas de socorro y asistencia humanitaria. Delito de mera conducta, de peligro, conducta instantánea y pluriofensivo.

\begin{tabular}{|c|c|c|c|}
\hline TIPO OBJETIVO & $\begin{array}{c}\text { TIPO } \\
\text { SUBJETIVO }\end{array}$ & ANTIJURICIDAD & CULPABILIDAD \\
\hline $\begin{array}{l}\text { Conducta: } \\
\text { Verbo rector: omitir, no } \\
\text { socorrer, no asistir } \\
\text { humanitariamente; } \\
\text { elemento descriptivo de } \\
\text { tiempo: durante conflicto } \\
\text { armado. } \\
\text { Sujeto Activo: } \\
\text { Cualificado, persona } \\
\text { obligada a socorrer y } \\
\text { asistir humanitariamente. } \\
\text { Sujeto Pasivo: } \\
\text { Indeterminado, persona en } \\
\text { estado de protección por el } \\
\text { D.I.H. } \\
\text { Objeto Jurídico: } \\
\text { Vida, integridad personal, } \\
\text { reglas protección D.I.H. } \\
\text { Objeto Material: } \\
\text { Personal. Persona } \\
\text { protegida. }\end{array}$ & $\begin{array}{l}\text { Modalidad } \\
\text { dogmática: } \\
\text { Conducta } \\
\text { dolosa } \\
\text { Atipicidad } \\
\text { Subjetiva: } \\
\text { Error de tipo, } \\
\text { ausencia de } \\
\text { dolo sobre } \\
\text { circunstancias } \\
\text { sujeto pasivo y } \\
\text { objeto } \\
\text { material. }\end{array}$ & $\begin{array}{l}\text { Juicio de contradicción } \\
\text { material: } \\
\text { Vulneración protección } \\
\text { internacional, peligro } \\
\text { efectivo para la vida del } \\
\text { sujeto pasivo. } \\
\text { Causas justificación } \\
\text { admisibles: } \\
\text { Excepcional: } \\
\text { cumplimiento de un } \\
\text { deber legal, orden } \\
\text { legítima, ejercicio de un } \\
\text { derecho, actividad lícita, } \\
\text { estado de necesidad. } \\
\text { Causas justificación } \\
\text { inadmisibles: } \\
\text { Consentimiento sujeto } \\
\text { pasivo, ejercicio de cargo } \\
\text { público, legítima defensa. }\end{array}$ & $\begin{array}{l}\text { Causas de Inculpabilidad. } \\
\text { Por inexigibilidad de } \\
\text { comportamiento } \\
\text { diferente: } \\
\text { Fuerza Mayor, caso fortuito, } \\
\text { insuperable coacción ajena, } \\
\text { miedo insuperable. } \\
\text { Por incapacidad de } \\
\text { culpabilidad: } \\
\text { Inimputabilidad por } \\
\text { trastorno mental. } \\
\text { Por falta de conocimiento } \\
\text { de la antijuricidad: } \\
\text { Excepcionalmente error de } \\
\text { prohibición. }\end{array}$ \\
\hline
\end{tabular}

Fuente: Pabón, 2006, pág. 134 


\section{Tabla 5}

"Artículo 161. Omisión de medidas de protección a la población civil. El que con ocasión y en desarrollo de conflicto armado, estando obligado a hacerlo, omita la adopción de medidas para la protección de la población civil, incurrirá en prisión de cuatro (4) a ocho (8) años y multa de doscientos (200) a mil (1000) salarios mínimos legales mensuales vigentes". (La pena fue agravada acorde a la ley 890 de 2004.)

ARTÍCULO 161. Omisión de medidas de protección a la población civil. Delito de mera conducta, de peligro, conducta instantánea y pluriofensivo.

\begin{tabular}{|c|c|c|c|}
\hline TIPO OBJETIVO & $\begin{array}{c}\text { TIPO } \\
\text { SUBJETIVO }\end{array}$ & ANTIJURICIDAD & CULPABILIDAD \\
\hline $\begin{array}{l}\text { Conducta: } \\
\text { Verbo rector: Omitir. } \\
\text { Descriptivamente la } \\
\text { acción la acción se } \\
\text { debe ejecutar con } \\
\text { ocasión del conflicto } \\
\text { armado. } \\
\text { Sujeto Activo: } \\
\text { Calificado. Obligado a } \\
\text { adoptar medidas para } \\
\text { protección población } \\
\text { civil. } \\
\text { Sujeto Pasivo: } \\
\text { El estado. } \\
\text { Objeto Jurídico: } \\
\text { Protección personal } \\
\text { del D.I.H. }\end{array}$ & $\begin{array}{l}\text { Modalidad } \\
\text { dogmática: } \\
\text { Normativamente } \\
\text { doloso. } \\
\text { Atipicidad } \\
\text { Subjetiva: } \\
\text { Error sobre los } \\
\text { elementos } \\
\text { descriptivos o el } \\
\text { objeto material. }\end{array}$ & $\begin{array}{l}\text { Juicio de contradicción } \\
\text { material: } \\
\text { Peligro efectivo a la } \\
\text { protección personal del } \\
\text { D.I.H. } \\
\text { Causas justificación } \\
\text { admisibles: } \\
\text { Excepcionalmente el } \\
\text { estado de necesidad. } \\
\text { Causas justificación } \\
\text { inadmisibles: } \\
\text { Consentimiento del } \\
\text { sujeto pasivo, } \\
\text { cumplimiento de un } \\
\text { deber, orden legítima, } \\
\text { ejercicio de un derecho, } \\
\text { actividad lícita, cargo } \\
\text { público. }\end{array}$ & $\begin{array}{l}\text { Causas de } \\
\text { Inculpabilidad: } \\
\text { Por inexigibilidad de } \\
\text { comportamiento } \\
\text { diferente: } \\
\text { Fuerza Mayor, caso } \\
\text { fortuito, insuperable } \\
\text { coacción ajena. } \\
\text { Por incapacidad de } \\
\text { culpabilidad: } \\
\text { Causas de } \\
\text { Inimputabilidad. } \\
\text { Por falta de } \\
\text { conocimiento de la } \\
\text { antijuricidad: } \\
\text { Error de prohibición. }\end{array}$ \\
\hline
\end{tabular}

Fuente: Pabón, 2006, pág. 143 


\section{Tabla 6}

“Artículo 219B. Omisión de denuncia. El que por razón de su oficio, cargo o actividad, tuviere conocimiento de la utilización de menores para la realización de cualquiera de las conductas previstas en el presente capitulo y omitiere información a las autoridades administrativas o judiciales competentes sobre tales hechos, teniendo el deber legal de hacerlo, incurrirá en multa de diez (10) a cincuenta (50) salarios mínimos legales mensuales vigentes. (La pena fue agravada acorde a la ley 890 de 2004.)

Si la conducta se realizare por servidor público, se impondrá, además la pérdida del empleo."

ARTíCULO 219B. Omisión de denuncia. Tipo de mera conducta, de lesión, de conducta instantánea y pluriofensivo.

\begin{tabular}{|l|l|l|l|}
\hline \multicolumn{1}{|c|}{ TIPO OBJETIVO } & \multicolumn{1}{|c|}{$\begin{array}{c}\text { TIPO } \\
\text { SUBJETIVO }\end{array}$} & \multicolumn{1}{|c|}{ ANTIJURICIDAD } & CULPABILIDAD \\
\hline $\begin{array}{l}\text { Conducta: } \\
\text { Verbo determinador: omitir } \\
\text { informar a la autoridad. }\end{array}$ & $\begin{array}{l}\text { Modalidad } \\
\text { dogmática: } \\
\text { Normativament } \\
\text { e doloso. }\end{array}$ & $\begin{array}{l}\text { Juicio de contradicción } \\
\text { material: } \\
\text { Lesión de los bienes } \\
\text { jurídicos comprometidos. }\end{array}$ & $\begin{array}{l}\text { Causas de } \\
\text { Inculpabilidad: } \\
\text { Por inexigibilidad de } \\
\text { comportamiento } \\
\text { diferente: }\end{array}$ \\
$\begin{array}{l}\text { Sujeto Activo: } \\
\text { Indeterminado singular. } \\
\text { Sujeto Pasivo: } \\
\text { El estado. }\end{array}$ & $\begin{array}{l}\text { Atipicidad } \\
\text { Subjetiva: } \\
\text { Error de tipo } \\
\text { sobre el objeto } \\
\text { material. }\end{array}$ & $\begin{array}{l}\text { admisibles: } \\
\text { Cumplimiento de un } \\
\text { deber. }\end{array}$ & $\begin{array}{l}\text { Fuerza Mayor, caso } \\
\text { fortuito, insuperable } \\
\text { coacción ajena, miedo } \\
\text { insuperable. }\end{array}$ \\
$\begin{array}{l}\text { Fojeto Jurídico: } \\
\text { sexual. }\end{array}$ & $\begin{array}{l}\text { Causas justificación } \\
\text { inadmisibles: }\end{array}$ & $\begin{array}{l}\text { Por incapacidad de } \\
\text { culpabilidad: }\end{array}$ \\
$\begin{array}{l}\text { Objeto Material } \\
\text { Fenoménico: Delito de } \\
\text { proxenetismo del que ha } \\
\text { tenido conocimiento el } \\
\text { agente. }\end{array}$ & $\begin{array}{l}\text { Consentimiento del sujeto } \\
\text { pasivo, actividad lícita, } \\
\text { cargo público, estado de } \\
\text { necesidad. }\end{array}$ & $\begin{array}{l}\text { Causas de } \\
\text { Inimputabilidad. } \\
\text { Por falta de } \\
\text { conocimiento de la } \\
\text { antijuricidad: } \\
\text { Error de prohibición. }\end{array}$ \\
\hline
\end{tabular}

Fuente: Pabón, 2006, pág. 209 


\section{Tabla 7}

"Artículo 325. Omisión de control. El empleado o director de una institución financiera o de cooperativas que ejerza actividades de ahorro y crédito que, con el fin de ocultar o encubrir el origen ilícito de dinero, omita el cumplimiento de alguno o todos los mecanismos de control establecidos por el ordenamiento jurídico para las transacciones en efectivo incurrirá, por esa sola conducta, en prisión de dos (2) a seis (6) años y multa de cien (100) a diez mil (10.000) salarios mínimos legales mensuales vigentes."

ARTíCULO 325. Omisión de control.Tipo de mera conducta, de peligro, conducta instantánea y mono ofensiva.

\begin{tabular}{|c|c|c|c|}
\hline $\begin{array}{c}\text { TIPO } \\
\text { OBJETIVO }\end{array}$ & $\begin{array}{c}\text { TIPO } \\
\text { SUBJETIVO }\end{array}$ & ANTIJURICIDAD & CULPABILIDAD \\
\hline $\begin{array}{l}\text { Conducta: } \\
\text { Verbo rector: } \\
\text { Omitir. } \\
\text { Sujeto Activo: } \\
\text { Con cualificación } \\
\text { jurídica y singular. } \\
\text { Sujeto Pasivo: } \\
\text { El estado. } \\
\text { Objeto Jurídico: } \\
\text { Orden económico } \\
\text { social. } \\
\text { Objeto Material } \\
\text { Fenoménico: } \\
\text { mecanismos de } \\
\text { control establecidos } \\
\text { por la ley. }\end{array}$ & $\begin{array}{l}\text { Modalidad } \\
\text { dogmática: } \\
\text { Normativa y } \\
\text { materialmente } \\
\text { doloso. } \\
\text { Atipicidad } \\
\text { Subjetiva: } \\
\text { Error de tipo } \\
\text { sobre la acción, } \\
\text { sus elementos } \\
\text { normativos y el } \\
\text { objeto material. }\end{array}$ & $\begin{array}{l}\text { Juicio de contradicción } \\
\text { material: } \\
\text { Amenaza efectiva para los } \\
\text { bienes jurídicos } \\
\text { comprometidos. } \\
\text { Causas justificación } \\
\text { admisibles: } \\
\text { Excepcionalmente estado de } \\
\text { necesidad. } \\
\text { Causas justificación } \\
\text { inadmisibles: } \\
\text { Consentimiento del sujeto } \\
\text { pasivo, cumplimiento de un } \\
\text { deber, orden legítima, } \\
\text { ejercicios de un derecho, } \\
\text { actividad lícita, cargo } \\
\text { público. }\end{array}$ & $\begin{array}{l}\text { Causas de } \\
\text { Inculpabilidad: } \\
\text { Por inexigibilidad de } \\
\text { comportamiento } \\
\text { diferente: } \\
\text { Insuperable coacción } \\
\text { ajena. } \\
\text { Por incapacidad de } \\
\text { culpabilidad: } \\
\text { No admite causas de } \\
\text { Inimputabilidad. } \\
\text { Por falta de } \\
\text { conocimiento de la } \\
\text { antijuricidad: } \\
\text { excepcionalmente error } \\
\text { de prohibición. }\end{array}$ \\
\hline
\end{tabular}

Fuente: Pabón, 2006, pág. 322 


\section{Tabla 8}

“Artículo 402. Omisión del agente retenedor o recaudador. El agente retenedor o auto retenedor que no consigne las sumas retenidas o auto retenidas por concepto de retención en la fuente dentro de los dos (2) meses siguientes a la fecha fijada por el Gobierno Nacional para la presentación y pago de la respectiva declaración de retención en la fuente o quien encargado de recaudar tasas o contribuciones públicas no las consigne dentro del término legal, incurrirá en prisión de tres (3) a seis (6) años y multa equivalente al doble de lo no consignado sin que supere el equivalente a los cincuenta mil (50.000 salarios) mínimos legales mensuales vigentes.

En la misma sanción incurrirá el responsable del impuesto sobre las ventas que, teniendo la obligación legal de hacerlo no consigue las sumas recaudadas por dicho concepto, dentro de los dos (2) meses siguientes a la fecha fijada por el Gobierno Nacional para la presentación y pago de la respectiva declaración del impuesto sobre las ventas.

Tratándose de sociedades u otras entidades, quedan sometidas a esas mismas secciones las personas naturales encargadas en cada entidad del cumplimiento de dichas obligaciones.

Parágrafo: El agente retenedor o auto retenedor, responsable del impuesto a las ventas o el recaudador de tasas o contribuciones públicas, que extinga la obligación tributaria por pago o compensación de las sumas adeudadas, según el caso, junto con sus correspondientes intereses previstos en el estatuto Tributario, y normas legales respectivas, se hará beneficiario de resolución inhibitoria, preclusión de investigación, o cesación de procedimiento dentro del proceso penal que se hubiera iniciado por tal motivo, sin perjuicio de las sanciones administrativas a que haya lugar". (La pena fue agravada acorde a la ley 890 de 2004.)

ARTÍCULO 402. Omisión del agente retenedor o recaudador. Tipo penal de mera conducta, de lesión, de conducta instantánea y mono ofensiva.

\begin{tabular}{|c|c|c|c|}
\hline TIPO OBJETIVO & TIPO SUBJETIVO & ANTIJURICIDAD & CULPABILIDAD \\
\hline $\begin{array}{l}\text { Conducta: } \\
\text { Verbo determinador: no } \\
\text { consignar. } \\
\text { Sujeto Activo: } \\
\text { Cualificado } \\
\text { jurídicamente y singular. } \\
\text { Sujeto Pasivo: } \\
\text { El Estado. } \\
\text { Objeto Jurídico: } \\
\text { Administración pública. } \\
\text { Objeto Material: } \\
\text { Sumas recaudadas por } \\
\text { retención en la fuente, } \\
\text { contribuciones públicas, } \\
\text { impuestos sobre las } \\
\text { ventas. }\end{array}$ & $\begin{array}{l}\text { Modalidad dogmática: } \\
\text { Normativamente doloso. } \\
\text { Atipicidad Subjetiva: } \\
\text { Error de tipo sobre el } \\
\text { contenido de la acción, } \\
\text { el objeto material o los } \\
\text { elementos normativos. }\end{array}$ & $\begin{array}{l}\text { Material: } \\
\text { Lesión al adecuado } \\
\text { recaudo de la retención } \\
\text { en la fuente, tasas o } \\
\text { contribuciones públicas, } \\
\text { impuesto sobre las } \\
\text { ventas. } \\
\text { Causas justificación } \\
\text { admisibles: } \\
\text { Cumplimiento de un } \\
\text { deber, orden legítima, } \\
\text { ejercicio de un derecho, } \\
\text { actividad lícita, cargo } \\
\text { público, estado de } \\
\text { necesidad. } \\
\text { Causas justificación } \\
\text { inadmisibles: } \\
\text { Consentimiento del } \\
\text { sujeto pasivo. }\end{array}$ & $\begin{array}{l}\text { Causas de } \\
\text { Inculpabilidad: } \\
\text { Por inexigibilidad de } \\
\text { comportamiento } \\
\text { diferente: } \\
\text { Fuerza mayor, caso } \\
\text { fortuito, insuperable } \\
\text { coacción ajena. } \\
\text { Por incapacidad de } \\
\text { culpabilidad: } \\
\text { Excepcionalmente } \\
\text { causas de } \\
\text { Inimputabilidad. } \\
\text { Por falta de } \\
\text { conocimiento de la } \\
\text { antijuricidad: } \\
\text { Error de prohibición. }\end{array}$ \\
\hline
\end{tabular}

Fuente: Pabón, 2006, pág. 405 


\section{Tabla 9}

"Artículo 414. Prevaricato por omisión. El servidor público que omita, retarde, rehúse o deniegue un acto propio de sus funciones, incurrirá en prisión de dos (2) a cinco (5) años, multa de diez (10) a cincuenta (50) salarios mínimos legales mensuales vigentes, e inhabilitación para el ejercicio de los derechos y funciones públicas por cinco (5) años”. (La pena fue agravada acorde a la ley 890 de 2004.)

\begin{tabular}{|c|c|c|c|}
\hline TIPO OBJETIVO & $\begin{array}{c}\text { TIPO } \\
\text { SUBJETIVO }\end{array}$ & ANTIJURICIDAD & CULPABILIDAD \\
\hline $\begin{array}{l}\text { Conducta: } \\
\text { Verbo determinador } \\
\text { compuesto alternativo: } \\
\text { omitir, rehusar, retardar, } \\
\text { denegar. } \\
\text { Sujeto Activo: } \\
\text { Cualificado jurídicamente y } \\
\text { singular: servidor público. } \\
\text { Sujeto Pasivo: } \\
\text { El Estado. } \\
\text { Objeto Jurídico: } \\
\text { Principio de legalidad de la } \\
\text { actividad estatal. } \\
\text { Objeto Material } \\
\text { fenoménico: } \\
\text { Acto propio de las } \\
\text { funciones del agente al cual } \\
\text { está obligado. }\end{array}$ & $\begin{array}{l}\text { Modalidad } \\
\text { dogmática: } \\
\text { Normativament } \\
\text { e doloso. } \\
\text { Atipicidad } \\
\text { Subjetiva: } \\
\text { Error de tipo } \\
\text { sobre el } \\
\text { objeto material. }\end{array}$ & $\begin{array}{l}\text { Material: } \\
\text { Lesión a la } \\
\text { administración pública. } \\
\text { Principio de legalidad en } \\
\text { la actividad estatal. } \\
\text { Causas justificación } \\
\text { admisibles: } \\
\text { Excepcionalmente } \\
\text { estado de necesidad. } \\
\text { Causas justificación } \\
\text { inadmisible. } \\
\text { Consentimiento del } \\
\text { sujeto pasivo, } \\
\text { cumplimiento de un } \\
\text { deber, orden legítima, } \\
\text { ejercicio de un derecho, } \\
\text { actividad lícita, cargo } \\
\text { público. }\end{array}$ & $\begin{array}{l}\text { Causas de } \\
\text { Inculpabilidad: } \\
\text { Por inexigibilidad de } \\
\text { comportamiento } \\
\text { diferente: } \\
\text { Fuerza mayor, caso } \\
\text { fortuito, insuperable } \\
\text { coacción ajena y } \\
\text { miedo insuperable. } \\
\text { Por incapacidad de } \\
\text { culpabilidad: } \\
\text { Excepcionalmente } \\
\text { causas de } \\
\text { Inimputabilidad. } \\
\text { Por falta de } \\
\text { conocimiento de la } \\
\text { antijuricidad: } \\
\text { Excepcionalmente } \\
\text { error de prohibición. }\end{array}$ \\
\hline
\end{tabular}

Fuente: Pabón, 2006, pág. 418 


\section{Tabla 10}

"Artículo 417. Abuso de autoridad por omisión de denuncia. El servidor público que teniendo conocimiento de la omisión de una conducta punible cuya averiguación deba adelantarse de oficio no dé cuenta a la autoridad, incurrirá en multa y pérdida de empleo o cargo público. La pena será de dos (2) a cuatro (4) años de prisión si la conducta punible que se omitiere denunciar sea de las contempladas en el delito de la omisión de denuncia de particular”. (La pena fue agravada acorde a la ley 890 de 2004.)

ARTíCULO 417. Abuso de autoridad por omisión de denuncia. Tipo de mera conducta, de lesión, conducta instantánea y mono ofensiva.

\begin{tabular}{|c|c|c|c|}
\hline TIPO OBJETIVO & $\begin{array}{c}\text { TIPO } \\
\text { SUBJETIVO }\end{array}$ & ANTIJURICIDAD & CULPABILIDAD \\
\hline $\begin{array}{l}\text { Conducta: } \\
\text { Verbo determinador } \\
\text { simple: no dar cuenta, no } \\
\text { denunciar. } \\
\text { Sujeto Activo: } \\
\text { Cualificado jurídicamente } \\
\text { y singular, Servidor } \\
\text { público. } \\
\text { Sujeto Pasivo: } \\
\text { El estado. } \\
\text { Objeto Jurídico: } \\
\text { Administración pública e } \\
\text { impartición de justicia. } \\
\text { Objeto Material } \\
\text { Fenoménico: } \\
\text { Conducta punible de cuya } \\
\text { comisión ha tenido } \\
\text { conocimiento el agente. }\end{array}$ & $\begin{array}{l}\begin{array}{l}\text { Modalidad } \\
\text { dogmática: }\end{array} \\
\text { Normativamente } \\
\text { doloso. } \\
\text { Atipicidad } \\
\text { Subjetiva: } \\
\text { Error de tipo } \\
\text { sobre el objeto } \\
\text { material, o los } \\
\text { elementos } \\
\text { normativos. }\end{array}$ & $\begin{array}{l}\text { Material: } \\
\text { Lesión a los deberes } \\
\text { de lealtad. } \\
\text { Causas justificación } \\
\text { admisibles: } \\
\text { Cumplimiento de un } \\
\text { deber, orden legítima, } \\
\text { ejercicio de un } \\
\text { derecho, actividad } \\
\text { lícita, cargo público, } \\
\text { estado de necesidad. } \\
\text { Causas justificación } \\
\text { inadmisibles: } \\
\text { Consentimiento del } \\
\text { sujeto pasivo, orden } \\
\text { legítima. }\end{array}$ & $\begin{array}{l}\text { Causas de } \\
\text { Inculpabilidad: } \\
\text { Por inexigibilidad de } \\
\text { comportamiento } \\
\text { diferente: } \\
\text { Fuerza mayor, caso } \\
\text { fortuito, insuperable } \\
\text { coacción ajena y } \\
\text { miedo insuperable. } \\
\text { Por incapacidad de } \\
\text { culpabilidad: } \\
\text { Excepcionalmente } \\
\text { causas de } \\
\text { Inimputabilidad. } \\
\text { Por falta de } \\
\text { conocimiento de la } \\
\text { antijuricidad: } \\
\text { Excepcionalmente } \\
\text { error de prohibición. }\end{array}$ \\
\hline
\end{tabular}

Fuente: Pabón, 2006, pág. 421 


\section{Tabla 11}

"Artículo 424. Omisión de apoyo. El agente de la Fuerza Pública que rehúse o demore indebidamente el apoyo pedido por autoridad competente, en la forma establecida por la ley, incurrirá en prisión de uno (1) a cuatro (4) años e inhabilitación para el ejercicio de derechos y funciones públicas por cinco (5) años". (La pena fue agravada acorde a la ley 890 de 2004.)

ARTíCULO 424. Omisión de apoyo. Tipo de mera conducta, de lesión, conducta instantánemono ofensiva.

\begin{tabular}{|c|c|c|c|}
\hline TIPO OBJETIVO & $\begin{array}{c}\text { TIPO } \\
\text { SUBJETIVO }\end{array}$ & ANTIJURICIDAD & CULPABILIDAD \\
\hline $\begin{array}{l}\text { Conducta: } \\
\text { Verbo determinador } \\
\text { compuesto alternativo: } \\
\text { rehusar o demorar. } \\
\text { Sujeto Activo: } \\
\text { Calificado jurídicamente } \\
\text { singular. Agente de la } \\
\text { Fuerza Pública. } \\
\text { Sujeto Pasivo: } \\
\text { El estado. } \\
\text { Objeto Jurídico: } \\
\text { Deberes constitucionales de } \\
\text { la Fuerza Pública. } \\
\text { Objeto Material } \\
\text { Fenoménico: } \\
\text { Apoyo de la Fuerza Pública } \\
\text { al que está obligado el } \\
\text { agente y no es prestado o lo } \\
\text { es en forma extemporánea. }\end{array}$ & $\begin{array}{l}\text { Modalidad } \\
\text { dogmática: } \\
\text { Normativamente } \\
\text { doloso. } \\
\text { Atipicidad } \\
\text { Subjetiva: } \\
\text { Error sobre los } \\
\text { elementos } \\
\text { normativos. }\end{array}$ & $\begin{array}{l}\text { Material: } \\
\text { Lesión al adecuado } \\
\text { cumplimiento de los } \\
\text { deberes constitucionales } \\
\text { de la Fuerza Pública. } \\
\text { Causas justificación } \\
\text { admisibles: } \\
\text { Cumplimiento de un } \\
\text { deber, orden legítima, } \\
\text { ejercicio de un derecho, } \\
\text { actividad lícita, cargo } \\
\text { público, estado de } \\
\text { necesidad. } \\
\text { Causas justificación } \\
\text { inadmisibles: } \\
\text { Consentimiento del } \\
\text { sujeto pasivo. }\end{array}$ & $\begin{array}{l}\text { Causas de } \\
\text { Inculpabilidad: } \\
\text { Por inexigibilidad de } \\
\text { comportamiento } \\
\text { diferente: } \\
\text { Fuerza mayor, caso } \\
\text { fortuito, } \\
\text { excepcionalmente } \\
\text { insuperable coacción } \\
\text { ajena. } \\
\text { Por incapacidad de } \\
\text { culpabilidad: } \\
\text { Excepcionalmente } \\
\text { causas de } \\
\text { Inimputabilidad. } \\
\text { Por falta de } \\
\text { conocimiento de la } \\
\text { antijuricidad: } \\
\text { Admite error de } \\
\text { prohibición. }\end{array}$ \\
\hline
\end{tabular}

Fuente: Pabón, 2006, pág. 424 


\section{Tabla 12}

“Artículo 441. Omisión de denuncia de particular. (Modificado por el Artículo 9 de la Ley 733 de enero 29 de 2002) El que teniendo conocimiento de la comisión de delitos de genocidio, desplazamiento forzado, tortura, desaparición forzada, homicidio, secuestro, secuestro extorsivo o extorsión, narcotráfico, tráfico de drogas tóxicas, estupefacientes o sustancias psicotrópicas, enriquecimiento ilícito, testaferrato, lavado de activos, cualquiera de las conductas contra personas y bienes protegidos por el Derecho Internacional Humanitario o de las conductas de proxenetismo cuando el sujeto pasivo sea un menor de doce (12) años, omitiere sin justa causa informar de ello en forma inmediata a la autoridad incurrirá en prisión de dos (2) a cinco (5) años.

La pena se aumentará en la mitad para el servidor público que cometa cualquiera de las anteriores conductas de omisión de denuncia".

ARTíCULO 441. Omisión de denuncia de particular. Tipo de mera conducta, de peligro, conducta instantánea y pluriofensiva.

\begin{tabular}{|c|c|c|c|}
\hline TIPO OBJETIVO & $\begin{array}{c}\text { TIPO } \\
\text { SUBJETIVO }\end{array}$ & ANTIJURICIDAD & CULPABILIDAD \\
\hline 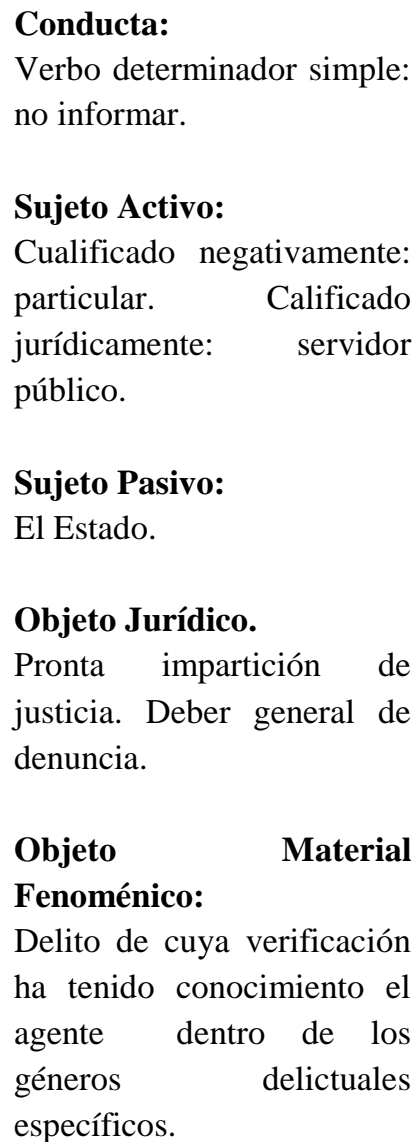 & $\begin{array}{l}\text { Modalidad } \\
\text { dogmática: } \\
\text { Normativamente } \\
\text { doloso. } \\
\text { Atipicidad } \\
\text { Subjetiva: } \\
\text { Erro de tipo sobre } \\
\text { el objeto material o } \\
\text { los elementos } \\
\text { normativos. }\end{array}$ & 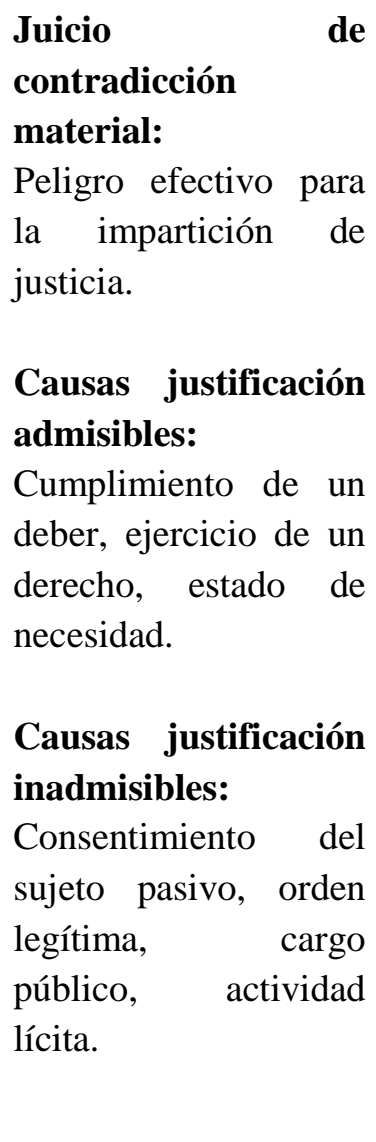 & $\begin{array}{l}\text { Causas de } \\
\text { Inculpabilidad: } \\
\text { Por inexigibilidad de } \\
\text { comportamiento } \\
\text { diferente: } \\
\text { Fuerza mayor, caso } \\
\text { fortuito, insuperable } \\
\text { coacción ajena, miedo } \\
\text { insuperable. }\end{array}$ \\
\hline
\end{tabular}

Fuente: Pabón, 2006, pág. 443 
Tabla 13

2.2. Cuadro esquemático Omisión Impropia.

\begin{tabular}{|c|c|c|c|c|}
\hline & \multirow{2}{*}{ EL SUJETO ACTIVO } & \multirow{2}{*}{ EL GARANTE } & \multicolumn{2}{|c|}{ COMO AUTOR } \\
\hline & & & \multicolumn{2}{|c|}{ COMO PARTICIPE } \\
\hline & EL SUJETO PASIVO & \multicolumn{3}{|c|}{ LA SOCIEDAD, LAS PERSONAS NATURALES } \\
\hline \multirow[t]{8}{*}{$\begin{array}{c}\text { LA } \\
\text { OMISIÓN } \\
\text { IMPROPIA } \\
\text { EN EL } \\
\text { CÓDIGO } \\
\text { COMÚN }\end{array}$} & $\begin{array}{c}\text { LA POSICIÓN } \\
\text { DE } \\
\text { GARANTE }\end{array}$ & \begin{tabular}{|l}
$\begin{array}{l}\text { ASUNCIÓN } \\
\text { VOLUNTARIA }\end{array}$ \\
$\begin{array}{l}\text { ESTRECHA } \\
\text { COMUNIDAD DE } \\
\text { VIDA }\end{array}$ \\
COMUNIDAD DE \\
RIESGO \\
CREACIÓN \\
PRECEDENTE \\
DE SITUACIÓN \\
ANTIJURÍDICA \\
DE RIESGO \\
(INJERENCIA)
\end{tabular} & $\begin{array}{l}\text { LA POSICIÓN } \\
\text { DE GARANTE } \\
\text { Y LA } \\
\text { FUERZA } \\
\text { PÚBLICA }\end{array}$ & $\begin{array}{l}(1) \\
\text { CREACIÓN DE } \\
\text { RIESGOS PARA } \\
\text { BIENES } \\
\text { JURÍDICOS } \\
\text { (1) } \\
\text { SURGIMIENTO DE } \\
\text { DEBERES POR LA } \\
\text { VINCULACIÓN A } \\
\text { UNA } \\
\text { INSTITUCIÓN } \\
\text { ESTATAL }\end{array}$ \\
\hline & \multirow{3}{*}{ BIENES JURÍDICOS } & \multicolumn{3}{|c|}{ LA VIDA Y LA INTEGRIDAD PERSONAL } \\
\hline & & \multicolumn{3}{|c|}{ LA LIBERTAD INDIVIDUAL } \\
\hline & & \multicolumn{3}{|c|}{ LA LIBERTAD Y FORMACIÓN SEXUALES } \\
\hline & \multirow{3}{*}{$\begin{array}{l}\text { CAPACIDADES } \\
\text { ( EL PODER ) }\end{array}$} & \multicolumn{3}{|l|}{ FUNCIONALES } \\
\hline & & \multicolumn{3}{|l|}{ TERRITORIALES } \\
\hline & & \multicolumn{3}{|l|}{ MATERIALES } \\
\hline & (2) TIPICIDAD & ANTIJURICIDAD & \multicolumn{2}{|c|}{ CULPABILIDAD } \\
\hline
\end{tabular}

1); (2): SU 1184 de 2001 
Tabla 14

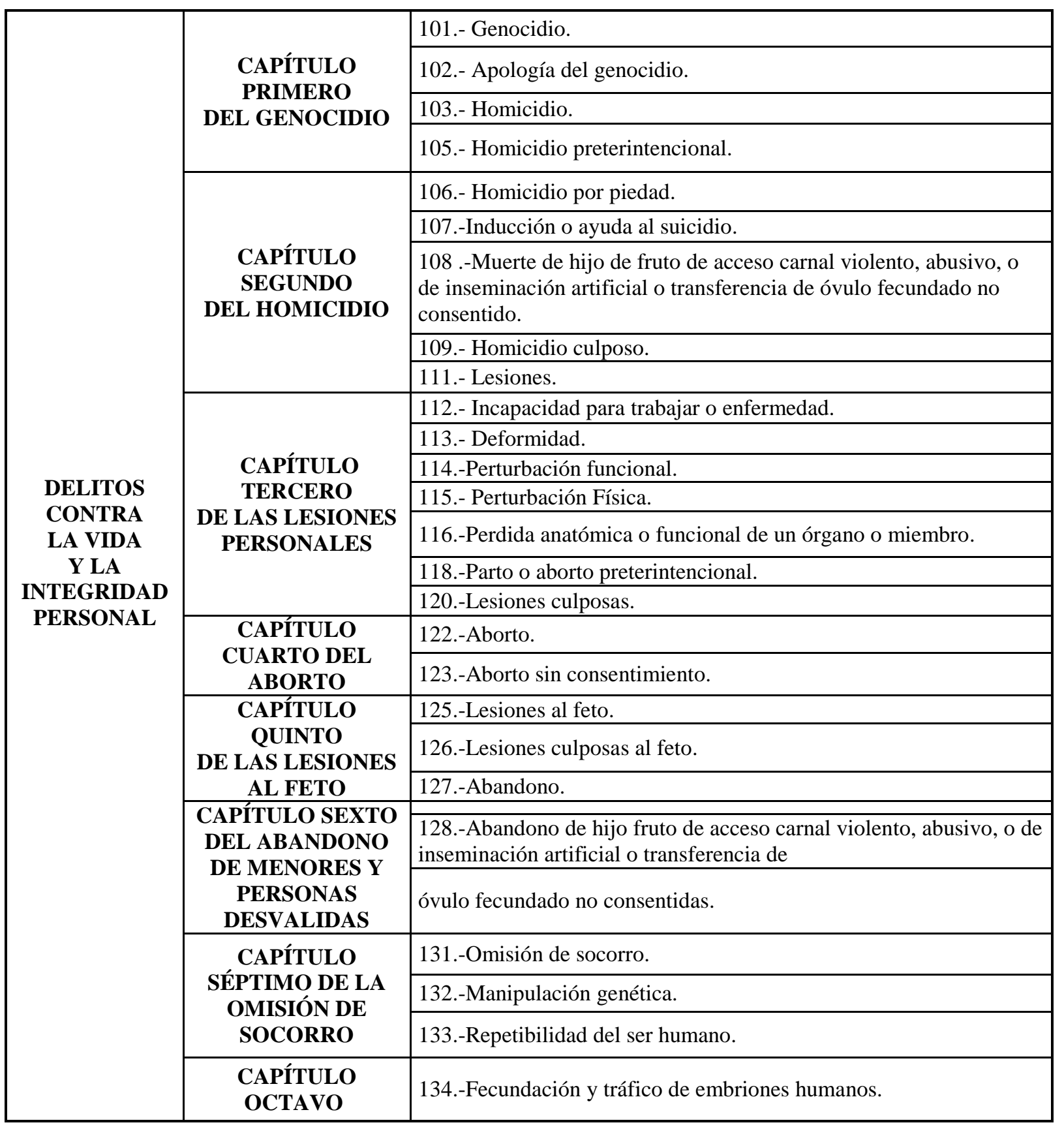


Tabla 15

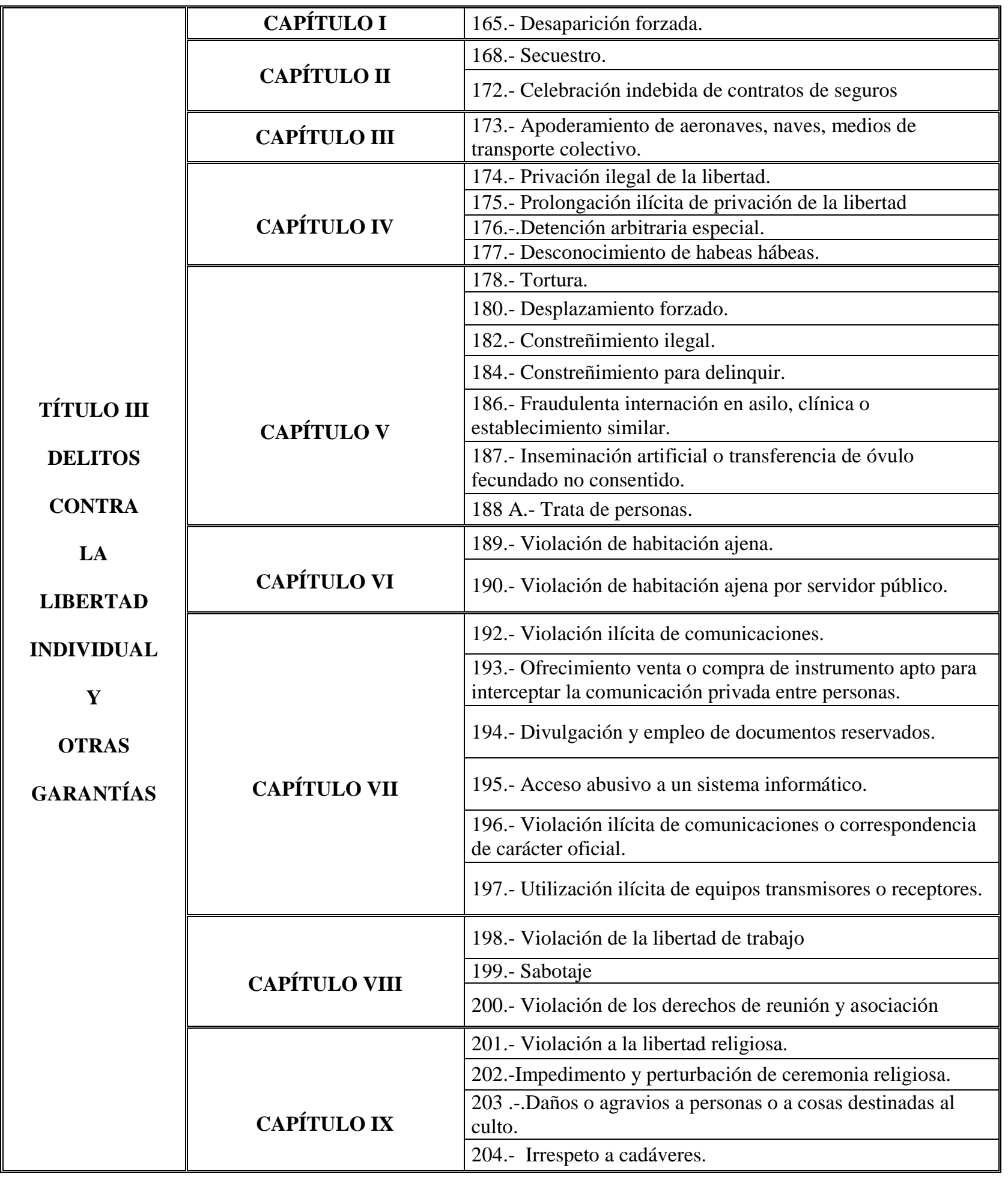


Tabla 16

\begin{tabular}{|c|c|c|}
\hline \multirow{16}{*}{$\begin{array}{c}\text { TITULO } \\
\text { IV } \\
\\
\text { DELITOS CONTRA } \\
\text { LA LIBERTAD, } \\
\text { INTEGRIDAD } \\
\text { Y } \\
\text { FORMACIÓN } \\
\text { SEXUAL }\end{array}$} & \multirow{3}{*}{ CAPÍTULO I } & 205.- Acceso carnal violento. \\
\hline & & 206.- Acto sexual violento. \\
\hline & & $\begin{array}{l}\text { 207.- Acceso carnal o acto sexual en persona puesta en } \\
\text { incapacidad de resistir. }\end{array}$ \\
\hline & \multirow{4}{*}{ CAPÍTULO II } & 208.- Acceso carnal abusivo con menor \\
\hline & & de catorce años. \\
\hline & & 209.- Actos sexuales con menor de catorce años. \\
\hline & & $\begin{array}{l}\text { 210.- Acceso carnal o acto sexual abusivos con incapaz } \\
\text { de resistir. }\end{array}$ \\
\hline & \multirow{3}{*}{ CAPÍTULO III } & 212.- Acceso carnal. \\
\hline & & 213.- Inducción a la prostitución \\
\hline & & 214.- Constreñimiento a la prostitución. \\
\hline & \multirow{6}{*}{ CAPÍTULO IV } & 215.- Trata de personas \\
\hline & & 217.- Estímulo a la prostitución de menores. \\
\hline & & 218.- Pornografía con menores. \\
\hline & & 219.- Turismo sexual. \\
\hline & & $\begin{array}{l}\text { 219A.- Utilización o facilitación de medios de } \\
\text { comunicación para ofrecer servicios sexuales de } \\
\text { menores. }\end{array}$ \\
\hline & & 219B.- Omisión de denuncia. \\
\hline
\end{tabular}




\section{BIBLIOGRAFÍA}

Acto Legislativo 02 de diciembre de 2003, "por medio del cual se modifican los artículos 15, 24, 28 y 250 de la Constitución Política de Colombia para enfrentar el terrorismo".

Agudelo Betancur, N. (2002). Curso de Derecho Penal: esquemas de delito. Bogotá: Edit. Temis.

Ambos, KaI (2001). Temas del Derecho Penal Internacional. Trad. de F. del Cacho, M. Karaán, O.J. Guerrero y J. Córdoba Triviño. Bogotá: Universidad Externado de Colombia, Centro de Investigaciones de Derecho Penal y Filosofía del Derecho.

Aponte Cardona, A. (2011). Persecución penal de crímenes internacionales. Bogotá: Ediciones Jurídicas Gustavo Ibáñez.

Arboleda Vallejo, Mario (2010). Código Penal Militar. Ley 1407 de 2010. 13ª ed. Bogotá: Leyer Editores.

BAQUeR, Miguel AlONSO (1985). Las preferencias estratégicas del militar español. Colección Adalid.

Baumann, JÜrgen (1981). Derecho Penal. Buenos Aires: Edic. Depalma.

CAncio Meliá, Manuel. Líneas Básicas de la Teoría de la Imputación Objetiva. Madrid: Ediciones Jurídicas. Disponible en: www.unifr.ch/ ddp1/derechopenal/Artículos/ a_20080527_35.pdf

CÍRCUlO DE LeCTORES (1992). Diccionario Larousse. Bogotá: Ediciones Larousse.

Clausewitz, Karl Von (1999). De la Guerra, Táctica y Estrategia. 1ª ed. Barcelona: Idea Universitaria.

Código de Procedimiento Penal (2011). Ley 600 de 2000. Bogotá: Legis.

Código de Procedimiento Penal (2011). Ley 906 de 2004. Bogotá: Legis.

Código Penal Colombiano (1986). Decreto 100 de 1980. $7^{\text {a }}$ ed. Compilación de Ortega Torres, Jorge. Bogotá: Edit. Temis.

Código Penal Colombiano (2010). Ley 599 de 2000. Bogotá: Legis.

Código Penal Militar (2010). Ley 1407 de 2010. Bogotá: Legis. 
Código Penal MilitaR (2010). Ley 522 de 1999. Bogotá: Legis.

Código Penal Militar. Decreto 2550 de 1988. Bogotá.

COMANDO DEL EJÉRCITO (2002). Fallo Disciplinario. Bogotá, junio 26.

Comando General Fuerzas Militares. Escuela Superior De Guerra (2006). Memorias, Cátedras y Seminarios. Bogotá.

Comando General Fuerzas Militares. Escuela SuPERIOR DE Guerra. Memorias Seminarios de Derechos Humanos 2003-2004. Bogotá.

COMISIÓN DE ESTUdiOS SOBRE LA VIOLENCIA (1987). Colombia: violencia y democracia. Bogotá: Universidad Nacional de Colombia.

COMité InTERnACIONAL DE LA CRUZ RojA (1990). Derecho Internacional Relativo a la Conducción de Hostilidades. Ginebra.

Consejo De Estado. Radicado 11837 de mayo de 1998. C.P.: Jesús María Carrillo Ballesteros. Bogotá.

CONSEJO DE ESTADO. Radicado 52001233100019970878901 (15838, 18075, 25212 acumulados), de mayo de 2011. C.P.: Jaime Orlando Santofimio Gamboa. Bogotá.

CONSEJO DE ESTADO. Radicado 52001-23-31-000-1998-00515-01 (18747) de mayo de 2011. C.P.: Jaime Orlando Santofimio Gamboa. Bogotá.

Constitución Política de Colombia de 1886 (1975). Bogotá: Talleres Gráficos Banco Popular.

CONSTITUCión PolítiCA DE COLOMBIA DE 1991 (2010). Bogotá: Legis.

Convenios de Ginebra, 12 de Agosto de 1949. (I -II -III -IV.) Comité Internacional de la Cruz Roja. 1986, Ginebra.

CóRdoba Triviño, JAIME (2001). Derecho Penal Internacional. Bogotá: Ediciones Jurídicas Gustavo Ibáñez.

Corte Constitucional. Sentencia C-574 de 1992. M.P. Ciro Angarita Barón. Bogotá.

Corte Constitucional. Sentencia C-358 de 1997. M.P. Eduardo Cifuentes Muñoz. Bogotá.

Corte Constitucional. Sentencia C-225 de 1995. M.P. Alejandro Martínez Caballero. Bogotá. 
Corte Constitucional. Sentencia C-563 de 1995. M.P. Carlos Gaviria Díaz. Bogotá.

Corte Constitucional. Sentencia C-578 de 1995. M.P. Eduardo Cifuentes Muñoz. Bogotá.

Corte Constitucional. Sentencia C-676 de 2001. M.P. Marco Gerardo Monroy Cabra. Bogotá.

Corte Constitucional. Sentencia SU-1184 de 2001. M.P. Eduardo Montealegre Lynett. Bogotá.

Corte Constitucional. Sentencia C-048 de 2001. M.P. Eduardo Montealegre Lynett. Bogotá.

Corte Constitucional. Sentencia C-1214 de 2001. M.P. Clara Inés Vargas Hernández. Bogotá.

Corte Constitucional. Sentencia C-251 de 2002. M.P. Eduardo Montealegre Lynett y Clara Inés Vargas Hernández. Bogotá.

Corte Constitucional. Sentencia C-171 de 2004. M.P. Marco Gerardo Monroy Cabra. Bogotá.

Corte Constitucional. Sentencia C-816 de 2004. M.P. Jaime Córdoba Triviño y Rodrigo Uprimny Yepes. Bogotá.

Corte Constitucional. Sentencia C-291 de 2007. M.P. Manual José Cepeda Espinosa. Bogotá.

Corte Constitucional. Sentencia C-1184 de 2008. M.P. Nilson Pinilla Pinilla. Bogotá.

Corte Constitucional. Sentencia T-363 de 1995. Exp. T-65213. M.P. José Gregorio Hernández Galindo. Bogotá.

Corte Constitucional. Sentencia T-363 de 1995. M.P. José Gregorio Hernández Galindo. Bogotá.

Corte Suprema de Justicia. Sala de Casación Penal. Proceso Nº 9785 de junio de 1995. M.P. Carlos Mejía Escobar. Bogotá.

Corte Suprema de Justicia. Sala de Casación Penal. Proceso No 9996 de septiembre de 1996. M.P. Fernando E. Arboleda Ripoll. Bogotá.

Corte Suprema de Justicia. Sala de Casación Penal. Proceso No 14124 de marzo de 2002. M.P. Carlos Mejía Escobar. Bogotá.

Corte Suprema de Justicia. Sala de Casación Penal, Proceso No.12742 de abril de 2003. M. P. Álvaro Orlando Pérez Pinzón. Bogotá. 
Corte Suprema de Justicia. Sala de Casación Penal. Proceso N 16636 de mayo de 2003. M.P. Álvaro Orlando Pérez Pinzón. Bogotá.

Corte Suprema de Justicia. Sala de Casación Penal. Proceso No 18850 de mayo de 2003. M.P. Yesid Ramírez Bastidas. Bogotá.

Corte Suprema de Justicia. Sala de Casación Penal. Proceso N 17765 de septiembre de 2003. M.P. Jorge Aníbal Gómez Gallego. Bogotá.

Corte Suprema de Justicia. Sala de Casación Penal. Proceso Nº 21241 de noviembre de 2004. M.P. Mauro Solarte Portilla. Bogotá.

Corte Suprema de Justicia. Sala de Casación Penal. Proceso N 22511de mayo de 2005. M.P. Álvaro Orlando Pérez Pinzón. Bogotá.

Corte Suprema de Justicia. Sala de Casación Penal. Proceso No 24031 de septiembre de 2006. M.P. Yesid Ramírez Bastidas. Bogotá.

Corte Suprema DE Justicia. Sala de Casación Penal. Proceso Nº 22354 de octubre de 2006. M.P. Yesid Ramírez Bastidas. Bogotá.

Corte Suprema de Justicia. Sala de Casación Penal. Proceso N 25536 de julio de 2006. M.P. Álvaro Orlando Pérez Pinzón. Bogotá.

Corte Suprema de Justicia. Sala de Casación Penal. Proceso N 25889 de abril de 2007. M.P. Sigifredo Espinosa Pérez y Álvaro Orlando Pérez Pinzón. Bogotá.

Corte Suprema de Justicia. Sala de Casación Penal. Proceso Nº 24448 de septiembre de 2007. M.P. Augusto Ibáñez Guzmán. Bogotá.

Corte Suprema de Justicia. Sala de Casación Penal. Proceso No 26266 de octubre 2009. M.P. Julio Enrique Socha Salamanca. Bogotá.

Corte Suprema de Justicia. Sala de Casación Penal. Proceso № 29221 de septiembre de 2009. M.P. Yesid Ramírez Bastidas. Bogotá.

Corte Suprema de Justicia. Sala de Casación Penal. Proceso N 32022 de septiembre de 2009. M.P. Sigifredo Espinosa Pérez, Bogotá.

Corte Suprema de Justicia. Sala de Casación Penal. Proceso N 25682 de octubre 2009. M.P. Yesid Ramírez Bastidas. Bogotá. 
Corte Suprema de Justicia. Sala de Casación Penal. Proceso No 31407 de agosto de 2010. M.P. María del Rosario González de Lemos. Bogotá.

Corte Suprema de Justicia. Sala de Casación Penal. Proceso N ${ }^{\circ} 35099$ de marzo 2011. M.P. Augusto J. Ibañez Guzmán. Bogotá.

Cortina, Adela (1999). El mundo de los valores. Ética mínima y educación. Bogotá, D.C.: El Búho Ltda.

Cury, EnRIQUe (2005). Derecho Penal, Parte General. $7^{a}$ ed. Santiago: Universidad Católica de Chile.

De Bordeje Morencos, Fernando (1981). Diccionario Militar Estratégico y Político. Madrid: Editorial San Martín.

De la PaVA Marulanda, R. (2007). Causales de ausencia de responsabilidad penal. Bogotá: Ediciones Jurídicas Gustavo Ibáñez.

De Mulinen, FREDERIC (1991). Manual sobre el Derecho de la Guerra para las Fuerzas Armadas. Ginebra: Comité Internacional de la Cruz Roja.

Escuela de Relaciones Civiles y Militares (1998). Fundamentos y Aplicación de la Acción Integral (G.P.). T. I. Departamento de Investigación y Doctrina.

ESCUEla DE RELACIONES CIVILES y MilitaRes (1999). Fundamentos y Aplicación de la Acción Integral (G.P.). T. II. Departamento de Investigación y Doctrina.

FEIJOO SÁNCHEZ, B. (2000). "El principio de confianza como criterio normativo de imputación en el derecho penal". En: Derecho Penal y Criminología. XXI (69).

Ferre Olive, J.C.; NúÑEz PaZ, M.Á. \& Ramírez Barbosa, P.A. (2010). Derecho Penal Colombiano, Parte General. Bogotá: Ediciones Jurídicas Gustavo Ibáñez.

FERRO TORRES G. (2007). “Origen y naturaleza de la Justicia Penal Militar”. En: Revista Acore. $\mathrm{N}^{\circ}$ 116. Bogotá: Editorial Carrea $7^{\mathrm{a}}$ Ltda.

Forero Ramírez, Juan Carlos (2002). El Delito de Omisión del Nuevo Código Penal. $1^{\text {a }}$ ed. Bogotá: Legis.

Fuerzas Militares De COlOMBIA (2001). Manual de Operaciones en Combate Irregular. FF.MM. 3-10 (Reservado). $1^{\text {a }}$ ed. Bogotá: Imprenta Fuerzas Militares. 
García Calleja, José Antonio (1987). La Identidad de las Fuerzas Armadas. Madrid: Servicio de Publicaciones del Estado Mayor del Ejército.

Garrido Montt, Mario (2003). Derecho Penal, Parte General, Nociones Fundamentales de la Teoría del Delito. T. II. $3^{\text {a }}$ ed. Santiago: Jurídica de Chile.

Gómez LóPEZ, JESÚs ORLANDO (2003). Teoría del delito. Bogotá: Ediciones Doctrina y Ley Ltda.

Gómez PAVAJEAu, CARlos ARTURo (2005). Intervención y Omisión. Bogotá: Giro Editores.

HeIKo, H. Lesch (1992). Das Problem der sukzessiven Beihilfe. Peter Lang. Frankfurt. 1992, pp. 284 y ss. Heiko H. Lesch. Intervención delictiva e imputación objetiva. Universidad Externado de Colombia. Centro de Investigaciones de Derecho Penal y Filosofía del Derecho. Bogotá. 1995, Traducción de Javier Sánchez-Vera y Gómez Trellez.

Henao Osorio, R.D. (2005). “Existe la Justicia Penal Militar en Colombia?”. En: Revista Fuerzas Armadas. N 194. Bogotá: Legis.

HERNÁNDEZ HOYOS, DIANA, (2012). Derecho Internacional Humanitario. $2^{\mathrm{a}}$ ed. Bogotá: Ediciones Nueva Jurídica.

Hernández Mondragón, MaUricio (1994). Derecho Internacional Humanitario. $2^{a}$ ed. Bogotá: Biblioteca Básica Derechos Humanos. Consejería Presidencial para los Derechos Humanos.

http://www.semana.com/noticias-nacion/mundo-farc/119209.aspx

Hurtado Pozo, José (2008). Nociones Básicas de Derecho Penal en Guatemala. Capítulo 4. Disponible en: www. unifr.ch/ ddp1/ derechopenal/ obras/ hurtadoPozo1/ indice.pdf

IZQUIERdo SÁNCHEZ, CRISTÓBAL (2006). “Comisión por omisión. Algunas consideraciones sobre la injerencia como fuente de la posición de garante". En: Revista Chilena de Derecho. Vol. 33. ${ }^{\circ}$ 2. Disponible en: www. scielo.cl/ scielo.php? pid=S0718-34372006000200007 \&script= sci_ arttext.

JAKOBS, G. (1994). La imputación objetiva en derecho penal. Trad. de M. Cancio Meliá. Bogotá: Universidad Externado de Colombia, Centro de Investigaciones de Derecho Penal y Filosofía del Derecho.

JAKOBS, G. (1996). "La imputación penal de la acción y la omisión”. Trad. de Javier Sánchez-Vera Gómez-Trelles. En: Cuadernos de Conferencias y Artículos. № 12. Bogotá: Universidad Externado de Colombia. 
JAKOBS, G. (2001). La imputación objetiva en derecho penal. Trad. de M. Cancio Meliá. Lima: Editora Jurídica Grijley.

Jakobs, G. y CAncio M. (2000). El Sistema Funcionalista del Derecho Penal. Lima: Editorial Grijley.

Jescheck, H.H., \& WeIgend, T. (2003). Tratado de Derecho Penal, Parte General. Vol. II. Madrid: Comares.

Juzgado Segundo Penal del Circuito Especializado de Antioquia (2010). Sentencia del 4 de agosto. Medellín, Antioquia.

LANDAZÁBAl REYES, FERnANDO (1997). La hora de la reflexión. Bogotá: Edit. Temis.

LEY 418 DE 1997. Instrumentos para la búsqueda de la convivencia y la eficacia de la justicia.

LEY 678 DE 2001. Acción de repetición.

LEY 684 DEL 13 DE AGOSTO DE 2001. Ley de Seguridad y Defensa Nacional (declarada inexequible).

LEY 836 DE 2003. Reglamento de Régimen Disciplinario Fuerzas Militares.

LOMbana TrujILlo, Édgar (2001). "Delitos de omisión”. En: Revista Universitas. Bogotá: Pontificia Universidad Javeriana.

LÓPEZ DÍAZ, Claudia (1998). Introducción a la Imputación Objetiva. Bogotá: Universidad Externado de Colombia, Centro de Investigaciones de Derecho Penal.

Manual de Estado Mayor (Reservado).

Manual de Estrategia Nacional (Reservado).

Manual de Estrategia Militar General de las Fuerzas Militares (Reservado).

Manual de derecho Operacional

Manual de operaciones y Maniobras de Combate Irregular

Martínez López, ANTONio José (2002). Régimen penal de la función pública. $2^{\mathrm{a}}$ ed. Bogotá: Ediciones Librería del Profesional. 
Medellín, Pedro (2008). “La frágil ética de los civiles”. En: Diario El Tiempo. Agosto 12.

Mendoza Palomino, Álvaro (1992). Teoría y sinopsis de la Constitución de 1991. $1^{\mathrm{a}}$ ed. Bogotá: Ediciones Doctrina y Ley.

Ministerio de Defensa NaCiOnal (1974). Reglamento de Conducción de Operaciones 1974. Chile: Ejército de Chile.

Ministerio de Defensa NACiOnAl (1997). Inteligencia Estratégica. 1ª ed. Bogotá: Comando General Fuerzas Militares.

Mir PUIG (1996). Derecho Penal, Parte General. $4^{\mathrm{a}}$ ed. Barcelona.

Molina Arrubla, C.M. (2003). Delitos contra la Administración Pública. Bogotá: Leyer.

MUNILLA GÓMEZ, EDUARDO. Introducción a la estrategia militar española. Colección Adalid.

Muñoz Conde, F. y García Arán, M. (1993). Derecho Penal, Parte General. Barcelona.

Novoa, Eduardo (2005). Curso de Derecho Penal Chileno. $3^{\text {a }}$ ed. T. I. Santiago: Editorial Jurídica de Chile.

Ortega Torres, Jorge (1986). Código Penal Compilado. 7ª Bogotá: Editorial Temis.

PABÓN GÓMEZ, GERMÁN (2003). De la casación y la revisión penal. $2^{\mathrm{a}}$ ed. Bogotá: Ediciones Doctrina y Ley Ltda.

Pabón PARra, Pedro Alfonso (2006). Código Penal Esquemático, Bogotá: Ediciones Doctrina y Ley.

Perdomo Torres, J.F. (2001a). El delito de comisión por omisión en el Nuevo Código Penal Colombiano. $1^{a}$ ed. Bogotá: Universidad Externado de Colombia.

PERDOMO TORRES, J.F. (2001b). La problemática de la posición de garante en los delitos de comisión por omisión. Bogotá: Universidad Externado de Colombia, Centro de Investigaciones de Derecho Penal y Filosofía del Derecho.

Periódico El Tiempo (2011). Cortes ofrecen al presidente reunión para hablar de polémicos fallos. Redacción Política. Bogotá.

Periódico El Tiempo. 04 de junio 2011. Bogotá.

Periódico El Tiempo. 11 de diciembre 2011. Bogotá. 
Periódico El Tiempo. 23 de enero de 2005. Bogotá.

Periódico El Tiempo. 25 de septiembre de 2008. Bogotá.

Politoff, Sergio; Matus, Jean Pierre y Ramírez, María Cecilia (2003). Lecciones de Derecho Penal Chileno. Parte General. $2^{\mathrm{a}}$ ed. Santiago: Ed. Jurídica de Chile.

PResidencia de la República, Ministerio de DEFEnSA NACIONAL (2002). Sector Defensa: Una visión, una misión, plan estratégico 2002-2006.

Presidencia de la República, Ministerio de Defensa Nacional (2003). Política de Defensa y Seguridad Democrática. República de Colombia.

PROTOCOLOS I Y II, A los Convenios de Ginebra, Comité Internacional de la Cruz Roja, 1986, Ginebra.

QUERO RODILES, FELIPE (1989). Introducción a la teoría de la Seguridad Nacional. Madrid, España.

RAMELli ARTEAGA, ALEJANDRO, (2011). Jurisprudencia Penal Internacional Aplicable en Colombia, Bogotá, Ediciones Uniandes.

Rangel SuÁrez, A. (1999). Colombia: Guerra en el Fin de Siglo. Bogotá: Tercer Mundo Editores.

REVISTA FUERZAS ARMADAS (2005). Estrategia Nacional y Estrategia Militar: Hacia la neutralización de la agresión terrorista en Colombia. Publicación Militar Especializada de la Escuela Superior de Guerra de Colombia. Bogotá: Legis. Edición Nº 194. Marzo.

Revista Acore No 116 Febrero de 2007.

Revista La Defensoría Pública de Colombia. № 5. Año 2004.

Revista Military Review. Mayo-junio de 1998.

Revista Semana (2011). Edición No 1513. Bogotá.

Revista Semana (2011). Edición N 1524. Bogotá.

Revista Semana (2012). Edición N 1576. Bogotá.

ReYes Alvarado, Yesid (2005). Imputación Objetiva. $3^{\text {a }}$ ed. Bogotá: Edit. Temis. 
Reyes Echandía, Alfonso (2002). Derecho Penal. Bogotá: Edit. Temis.

RodríGuez, R. LiBARdo (2000). Derecho Administrativo General y Colombiano. Bogotá: Edit. Temis.

Rousseau, J.J. (1762). Contrato Social. Trad. de F. De los Ríos. Madrid: Espasa-Calpe.

SÁCHICA, LuIS CARlos (1972). Constitucionalismo Colombiano. $3^{\text {a }}$ ed. Bogotá: Edit. Temis.

SÁNCHEZ HERRERA, ESIQUiO MANUEL (2002). Imputación objetiva y delito imprudente. $1^{\mathrm{a}}$ ed. Bogotá: Giro Editores Ltda.

SÁNCHEZ-VERA GÓMEZ-TRELLES, JAVIER (1997). Intervención omisiva, posición de garante y prohibición de sobrevaloración del aporte. Bogotá: Universidad Externado de Colombia, Centro de Investigaciones de Derecho Penal y Filosofía del Derecho.

Sandoval Mesa, Jaime Alberto (2003). La incorporación de la Corte Penal Internacional. $1^{a}$ ed. Bogotá: Ediciones Nueva Jurídica.

Silva SÁnchez, Jesús MARÍA (2004). Estudios sobre los Delitos de Omisión. Lima: Editorial Jurídica Grijley.

Terragni, Marco Antonio (2008). Omisión impropia y posición de garante. Titular Cátedra Derecho Penal. Santa Fe, Argentina: Universidad Nacional del Litoral. Disponible en: www. terragnijurista. com.ar/ libros/oi_pg.htm

Texto Especial de patrullaje

Tribunal SuPERIOR Militar. Rad. No 090-144270-5693-2006-PNC, junio de 2006. M.P.: Teniente Coronel Tulia Clemencia González Pérez. Bogotá.

TRIBUNAL SUPERIOR MiLITAR. Rad. N 149202-9767-XI-567-0017/02-03-04/PONAL, de marzo de 2004. M.P.: Mayor ® Imelda Triviño Lopera. Bogotá.

TRIBUNAL SUPERIOR MiLITAR. Rad. N 149523-6745-066-PONAL, de mayo de 2006. M.P.: Mayor Jacqueline Rubio Barrera. Bogotá.

TribunAl SuPERIOR Militar. Rad. N N $^{\circ}$ 149964-ARC-6783-2709, de agosto de 2004. M.P.: Coronel® Jorge H. Barrios Garzón. Bogotá. 
Tribunal Superior MiLitar. Rad. N 150489-4015-XIII-427, Providencia No 194, de diciembre de 2006. M.P.: Mayor ${ }^{\circledR}$ Yesid Santofimio Murcia. Bogotá.

Universidad EXTERnado DE Colombia (2001). Centro de Investigaciones de Derecho Penal y Filosofía del Derecho, Cuadernos de Conferencias y Artículos. $N^{\circ} 26$.

UNIVERSIDAD EXTERNADO DE COLOMBIA (2009). "La imputación penal de la acción y de la omisión de Günther, Jakobs". Trad. de Javier Sánchez y Vera Gómez. En: Cuaderno de Conferencias y Artículos. $\mathrm{N}^{\circ} 12$, Trilles.

USTA. UnIVERSIDAD SANTO TOMÁS DE AQUINo (2008). Facultad de Derecho, Objetivos. Maestría en Derecho Penal. Disponible en: www.usta.edu.co

VAlencia MartíneZ, Jorge. E. (2006). Defensas penales, consultas y dictámenes. T. III. Bogotá: Ediciones Doctrina y Ley.

Vargas García, J. (2006). "Posición de Garante de los Miembros de la Fuerza Pública". En: Revista de Derecho. IX (18).

VARGAS GARCÍA, J. CARDENAS POBEDA, M. DUSSÁN, O. "Delitos de Omisión Impropia." Bogotá. Edit. IBAÑEZ.

WAng, Sheng. Teoría y Práctica de la Guerra Política. Trad. al español por el Prof. Chang KuanTsao.

Web: http://www.hchr.org.co

www.colarebo.com [05 de junio 2011].

Www.ramajudicial.gov, Consejo de Estado, comunicado del 31 de mayo de 2001.

ZAFFARONI, E.R. (2004). "Consideraciones sobre la prueba del dolo". En: Revista de Estudios de Justicia. $\mathrm{N}^{\circ} 4$.

Zaffaroni, E.R. (2006). Manual de Derecho Penal, Parte General. Bogotá: Edit. Temis. 